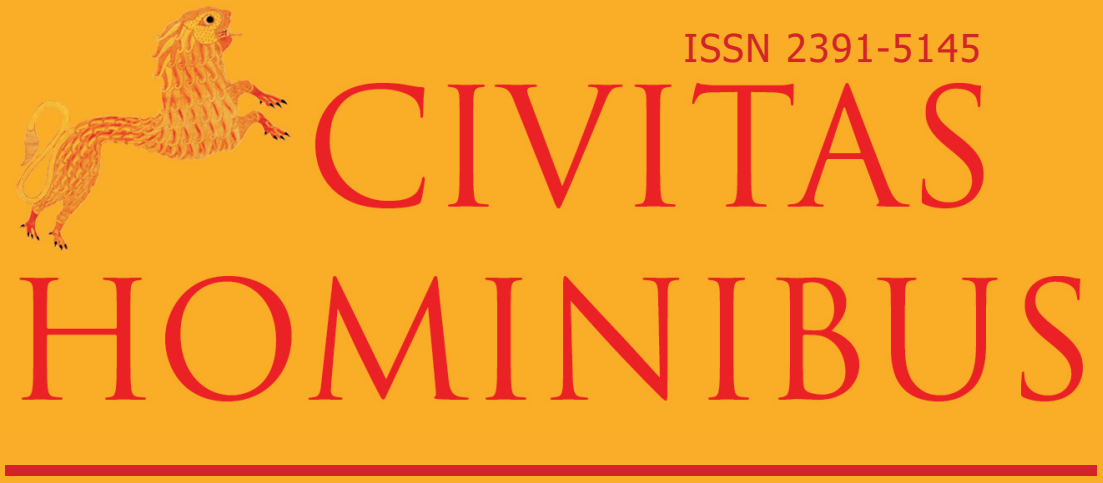

ROCZNIK FILOZOFICZNO-SPOŁECZNY VOL. 14/2019

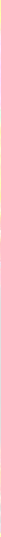




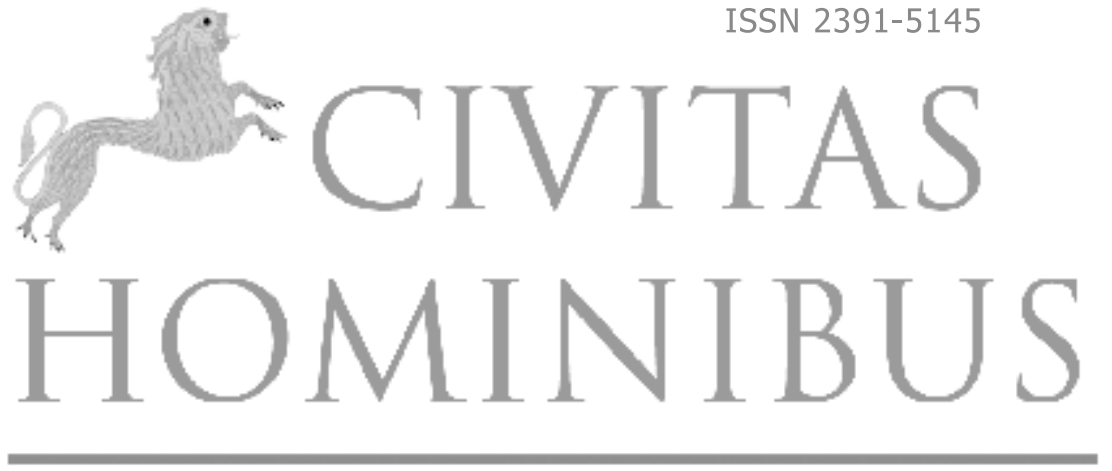

ROCZNIK FILOZOFICZNO-SPOŁECZNY VOL. 1(14)/2019 


\section{Redaktor naczelna:}

Dr hab. Edyta Pietrzak, prof. PŁ (Politechnika Łódzka)

Redakcja tematyczna:

Dr Agata Andrzejewska (Akademia Humanistyczno-Ekonomiczna w Lodzi) - sekretarz

Dr Łukasz Zaorski-Sikora (Akademia Humanistyczno-Ekonomiczna w Łodzi)

Redakcja językowa:

Dr Ewa Gdak (Akademia Humanistyczno-Ekonomiczna w Łodzi) - teksty polskojęzyczne

Mgr Marcin Jaźwiec (Akademia Humanistyczno-Ekonomiczna w Łodzi) - teksty anglojęzyczne

Poprzedni redaktorzy naczelni:

Prof. dr hab. Marek J. Malinowski, lata 2011-2018

Prof. dr hab. Franciszek Gołembski, lata 2006-2010

\section{Rada programowa:}

Prof. dr hab. Roman Bäcker (Uniwersytet Mikołaja Kopernika w Toruniu)

Dr hab. Tadeusz Dmochowski, prof. UG (Uniwersytet Gdański)

Prof. Jeff Holdeman (Indiana University)

Prof. dr hab. Bogusław Jagusiak (Wojskowa Akademia Techniczna)

Dr hab. Inga Kuźma, prof. UŁ (Uniwersytet Łódzki)

Prof. dr hab. Marek J. Malinowski - Honorowy członek Rady

Dr hab. Rafał Ożarowski, prof. WSAiB (Wyższa Szkoła Administracji i Biznesu)

Prof. Pinar Melis Yelsali Parmaksiz (Bahcesehir University)

Prof. dr hab. Stanisław Parzymies (Akademia Finansów i Biznesu Vistula)

Dr hab. Maciej Potz, prof. UŁ (Uniwersytet Łódzki)

Prof. Elena Shlienkova (Samara State University of Architecture and Civil Engineering)

Dr Makary Stasiak, prof. AHE (Akademia Humanistyczno-Ekonomiczna w Łodzi)

\section{Recenzenci spoza redakcji:}

Dr hab. Piotr Bohdziewicz, prof. UŁ (Uniwersytet Łódzki)

Dr hab. Tadeusz Dmochowski, prof. UG (Uniwersytet Gdański)

Prof. dr hab. Bogusław Jagusiak (Wojskowa Akademia Techniczna)

Prof. dr hab. Elżbieta Jung (Uniwersytet Łódzki)

Dr hab. Krystyna Leszczyńska (Uniwersytet Marii Curie-Skłodowskiej w Lublinie)

Dr hab. Dominik Mierzejewski, prof. UŁ (Uniwersytet Łódzki)

Dr hab. Joanna Mysona-Byrska, prof. UPJPII (Uniwersytet Papieski Jana Pawła II w Krakowie)

Dr hab. Marek, prof. UŁ Ostrowski (Uniwersytet Łódzki)

Dr hab. Rafał Ożarowski, prof. WSAiB (Wyższa Szkoła Administracji i Biznesu)

Prof. dr hab. Stanisław Parzymies (Akademia Finansów i Biznesu Vistula)

Dr hab. Roman Pelczar, prof. KUL(Katolicki Uniwersytet Lubelski)

Prof. dr hab. Agnieszka Rothert (Uniwersytet Warszawski)

Prof. dr hab. Grzegorz Sztabiński (Uniwersytet Łódzki)

Prof. dr hab. Janusz Świniarski (Wojskowa Akademia Techniczna)

Dr hab. Ireneusz Marian Świtała, prof. UP (Uniwersytet Pedagogiczny w Krakowie)

Prof. dr hab. Grażyna Ulicka (Uniwersytet Warszawski)

Prof. dr hab. Arkadiusz Żukowski (Uniwersytet Warmińsko-Mazurski)

Dr hab. Helena Marzec, prof. UJK (Uniwersytet Jana Kochanowskiego)

Dr hab. Katarzyna Dośpiał-Borysiak (Uniwersytet Łódzki)

Dr hab. Marta Witkowska (Uniwersytet Warszawski)

\section{Redakcja czasopisma „Civitas Hominibus"}

Akademia Humanistyczno-Ekonomiczna w Łodzi

90-212 Łódź, ul. Sterlinga 26

tel. 426315070

(C) Copyright by Akademia Humanistyczno-Ekonomiczna w Lodzi

Łódź 2019

\section{ISSN 2391-5145}

wersja elektroniczna na podstawie wersji papierowej

Korekta: Iwona Cłapińska (PUW)

Sklad DTP: Monika Poradecka (PUW)

\section{Wydawnictwo Akademii Humanistyczno-Ekonomicznej w Lodzi}

90-212 Łódź, ul. Sterlinga 26; tel. 426315908

wydawnictwo@ahe.lodz.pl www.wydawnictwo.ahe.lodz.pl 


\section{Spis treści}

Od Redakcji

ARTYKUŁY - DYSKUSJE - ESEJE

Anna Sikora

Pusty tron władzy, czyli o dylematach władzy ludu w demokracjach

Anna Fligel

Shmuel N. Eisenstadt w nowej odsłonie. Wokół książki

Varieties of Multiple Modernities. New Research Design

Waldemar Mańkowski

Polityka gospodarcza jako działanie państwa na tle globalnych zmian ... 39

Robert Krzemień

Patriotyzm ekonomiczny - droga do wzmocnienia gospodarki

czy droga donikąd?

Weronika Wojtanowska

O możliwości zastosowania Nagelowskiej typologii racji do działania we współczesnej etyce cnót

MISCELLANEA

Angelika Gieraś

Problem demokracji w Unii Europejskiej

PRACE STUDENCKIE

Galyna Biletska

Analysis of support levels for far-right political parties

in Sweden and France

Faina Nakanechnaya

The meaning of borders in post-Soviet countries

(Belarus and neighbouring countries) 
Sonia Rojeska

Gender imbalance in the political landscape and mainstream media discourse in Poland

Magdalena Wojtas

Aspects of the European Union's climate policy in the context

of the opportunities offered by the building sector - innovation

in action

RECENZJE

Marta Miedzińska

P. Mikuli (red.), Instytucje ombudsmana w państwach anglosaskich:

studium porównawcze, Warszawa 2017

Edyta Pietrzak

Joanna Sośnicka (ed.), Engineer with a Humanist's Soul.

Humanistic Issues of Technological World, Łódź 2019 


\section{List of Contents}

From Editors

ARTICLES - DISCUSSIONS - ESSEYS

Anna Sikora

The empty throne of power: the dilemmas of peoples' authorities in a democratic system

Anna Fligel

Shmuel N. Eisenstadt in a new setting.

Varieties of Multiple Modernities. New Research Design

Waldemar Mańkowski

Economic policy as a state action against the backdrop

of global changes

Robert Krzemień

Economic patriotism - the road to strengthen the economy

or the road nowhere?

Weronika Wojtanowska

On the possibility of applying Nagel's typology of reasons for action in contemporary virtue ethics

MISCELLANEA

Angelika Gieraś

The problem of democracy in the European Union

STUDENTS' WORKS

Galyna Biletska

Analysis of support levels for far-right political parties in Sweden and France 
Faina Nakanechnaya

The meaning of borders in post-Soviet countries

(Belarus and neighbouring countries)

Sonia Rojeska

Gender imbalance in the political landscape and mainstream media

discourse in Poland

Magdalena Wojtas

Aspects of the European Union's climate policy in the context of the opportunities offered by the building sector - innovation in action

REVIEWS

Marta Miedzińska

P. Mikuli (ed.), Instytucje ombudsmana w państwach anglosaskich:

studium porównawcze [Ombudsman institutions

in Anglo-Saxon countries: comparative study], Warszawa 2017

Edyta Pietrzak

Joanna Sośnicka (ed.), Engineer with a Humanist's Soul.

Humanistic Issues of Technological World, Łódź 2019 


\section{Od Redakcji}

Redakcja Rocznika Filozoficzno-Społecznego Civitas Hominibus ma przyjemność przedstawić XIV numer czasopisma, zatytułowany Czas interregnum.

Pojęcie interregnum zaczerpnięte przez Zygmunta Baumana od Antonia Gramsciego oznacza bezkrólewie, stan pośredni, przełom, czas upadku starego porządku i nastanie nowych możliwości oraz fazę między systemami, działającym porządkiem instytucjonalnym, tworzącym polityczne i ekonomiczne ramy funkcjonowania ludzkiej kultury a porządkiem nowym. Stan, w którym stare strategie przestały działać, a nowe są dopiero na etapie projektowania.

Określając nasze dzisiejsze czasy tym mianem, mamy na myśli okres rozciągający się między układem społecznym, który dobiegł końca, a kolejnym, który jeszcze nie nastał, ale jak się spodziewamy, zastąpi ten poprzedni. Stare fragmenty struktury społecznej obumierają, a ich fragmenty układają się w nowe, emergentne, niedopasowane jeszcze układy. Idea bezkrólewia pozbawiona monarchicznego sensu odrzuca bowiem wizję przesądzonej z góry przyszłości i zostawia ją niedookreśloną na pastwę ludzkich wyborów.

$\mathrm{W}$ numerze znajdują się artykuły podejmujące zagadnienie interregnum $\mathrm{w}$ aspektach politycznym, społecznym, ekonomicznym, kulturowym, technologicznym czy ekologicznym. Dział Artykuly zwiera teksty: Anny Sikory, Pusty tron władzy, czyli o dylematach władzy ludu w demokracjach, Anny Fligiel, Shmuel N. Eisenstadt w nowej odstonie. Wokót ksiażki „Varieties of Multiple Modernities. New Research Design”, Waldemara Mańkowskiego, Polityka gospodarcza jako działanie państwa na tle globalnych zmian, Roberta Krzemienia, Patriotyzm ekonomiczny - droga do wzmocnienia gospodarki czy droga donikad? oraz Weroniki Wojtanowskiej, O możliwości zastosowania Nagelowskiej typologii racji do dziatania we wspótczesnej etyce cnót.

W dziale Miscellanea prezentujemy esej Angeliki Gieraś pt. Problem demokracji w Unii Europejskiej. 
W części zawierającej prace studenckie znajdują się cztery ekstrakty prac magisterskich pisanych na kierunku Political Science. Autorkami tych tekstów są Galyna Biletska, Faina Nakanechnaya, Sonia Rojeska i Magdalena Wojtas.

Dział recenzyjny tworzą recenzje książek: Instytucje ombudsmana w państwach anglosaskich: studium porównawcze, pod red. P. Mikulego oraz Engineer with a Humanist's Soul. Humanistic Issues of Technological World Joanny Sośnickiej. 


\section{Anna Sikora (i) https://orcid.org/0000-0003-4178-4115 \\ sikora.ann@gmail.com}

Uniwersytet SWPS

\section{Pusty tron władzy, czyli o dylematach władzy ludu w demokracjach}

Jedną z najbardziej popularnych definicji demokracji są słowa Abrahama Lincolna z mowy gettysburskiej: „rządy ludu, dla ludu, przez lud sprawowane”. Nie jest to całościowa definicja demokracji, ale z całą pewnością oddaje ducha ustroju, w którym to mityczny tron władzy oddany jest $\mathrm{w}$ ręce kilkumilionowego suwerena. $\mathrm{W}$ ostatnich latach politycy coraz częściej odwołują się do woli suwerena jako do motywatora podejmowania decyzji. W artykule zostanie podniesiona kwestia wątpliwości kryjących się za zasadą reprezentacji - naczelną zasadą demokracji. To właśnie dzięki reprezentantom lud sprawuje władzę w państwach demokratycznych. Celem artykułu jest ich przeanalizowanie oraz rozważenie, czy całkowite „rządy ludu, dla ludu, przez lud sprawowane” są możliwe do wprowadzenia we współczesnych państwach demokratycznych.

\section{Władza ludu, czyli kogo?}

Pierwsza wątpliwość dotycząca „władzy ludu” wynika z możliwych interpretacji, czym jest lud. Giovanni Sartori twierdzi, że istnieje sześć możliwych interpretacji. Pierwsza jest najbardziej intuicyjna i oznacza dosłownie wszystkich. W warunkach demokracji jest to niemożliwe do spełnienia. Zawsze będzie istnieć grupa wykluczonych, chociażby z powodu wieku. Druga oznaczałaby bliżej nieokreśloną dużą część lub bardzo wielu ludzi. Takie sformułowanie wymagałoby każdorazowego tłumaczenia, ilu osób potrzeba do uznania wielu za grupę wystarczającą do określenia ich mianem ludu. Trzecia opcja jest całkowicie niedemokratyczna, ponieważ utożsamia lud z klasą niższą. Kolejna interpre-

\footnotetext{
${ }^{1}$ A. Lincoln, Przemowa gettysburska, 19 listopada 1863, https://www.fold3.com/image/4346725.
} 
tacja również nie sprzyja budowaniu demokracji, gdyż zakłada, że demos to zbiorowość, jednak pojmowana nie jako suma jednostek, ale pewna ograniczona całość. W imię tej całości prawa jednostek mogą być podważane. Prowadzi to do autorytaryzmu. Piąta i szósta możliwość rozumie lud jako większą część całości. W piątej jest wyrażona poprzez zasadę absolutnej większości, natomiast w szóstej poprzez większość ograniczoną². Dopiero ostatnie wyjaśnienie pozwala na uznanie $l u d u$ za społeczeństwo żyjące w ramach państwa demokratycznego. Dlatego władza ludu w warunkach współczesnej demokracji oznacza: rządy większości nad mniejszością z zachowaniem praw mniejszości

Tak zdefiniowany lud nie może sprawować władzy samodzielnie. „Sprawowanie suwerennej władzy przez naród na zasadzie reprezentacji politycznej, czyli w formie demokracji przedstawicielskiej, sprowadza się w głównej mierze do tego, że wszelkie decyzje o istotnym znaczeniu dla państwa podejmowane są w imieniu suwerena (narodu) przez jego najwyższy organ przedstawicielski (parlament) złożony z reprezentantów (posłów oraz senatorów) wyłonionych z woli narodu w drodze demokratycznej procedury wyborczej" ". Oznacza to, że naczelną zasadą demokracji jest reprezentacja, której źródłem władzy jest wola większości. Z zastrzeżeniem, że nie wolno naruszać praw mniejszości. Władza ludu w demokracjach musi więc być ograniczana.

\section{Idea reprezentacji}

Istotą reprezentacji jest właśnie bardzo szerokie zaufanie do drugiego człowieka. W tym sensie jest to jedna z najbardziej ryzykownych form zaufania ${ }^{5}$, gdyż jednostka bądź grupa osób powierza swoje interesy innym. Hannah Pitkin wyróżnia cztery typy reprezentacji. Reprezentacja formalna odnosi się do statusu reprezentanta jako osoby, która otrzymała upoważnienie do występowania $\mathrm{w}$ imieniu innych osób oraz jego odpowiedzialności. Reprezentacja symboliczna wiąże się z symboliką aktu. Trzeci rodzaj - reprezentacja deskryptywna - zwraca uwagę na reprezentatywność osoby reprezentanta przed reprezentowanymi. Ostatni rodzaj polega na działaniu i nosi nazwę reprezentacji rzeczywistej ${ }^{6}$. Kluczem do zrozumienia reprezentacji politycznej jest właśnie działanie w celu osiągnięcia wspólnego dobra. Koncepcja reprezentacji jest obarczona kilkoma wątpliwościami, które rzutują na pytanie: Kto formalnie zajmuje tron władzy w demokracjach?

Reprezentować dosłownie znaczy działać w czyimś imieniu. W monarchiach tradycyjnych źródłem władzy był Bóg. Autorytet władcy jest wertykalny, ponieważ pochodzi od Boga, a nie od ludu. Monarcha nawet absolutny nie jest samowładcą, ale jedynie (lub aż) sługą prawa Bożego. „Monarchia to świat prawa obiektywnego, który nie ma w swojej

${ }^{2}$ G. Sartori, Teoria demokracji, Wydawnictwo Naukowe PWN, Warszawa 1998, s. 38-42.

3 Tamże, s. 41.

${ }^{4}$ S. Bożyk, Partie polityczne a Sejm RP, Wydawnictwo Sejmowe, Warszawa 2006, s. 11.

5 P. Sztompka, Kapitat społeczny. Teoria przestrzeni międzyludzkiej, Społeczny Instytut Wydawniczy Znak, Kraków 2016.

${ }^{6}$ H.F. Pitkin, The Concept of Representation, University of California Press, Berkeley-Los Angeles-London 1967, s. 38-143. 
zasadzie niczego «ludzkiego», który wyklucza samowolę"7. Mityczny tron władzy w takim ujęciu należy do Boga, a w jego imieniu zasiada na nim wybrany przez Stwórcę namiestnik. Idea współczesnej reprezentacji jest próbą przełożenia tej koncepcji na zwierzchność ludu. Współczesna idea reprezentacji opiera się na banalnym stwierdzeniu, że lud potrzebuje swoich namiestników, którzy będą sprawować władzę w ich imieniu. Władza natomiast potrzebuje ludu, który będzie uwiarygodniał jej rządy. W przypadku monarchii tradycyjnych tym uwiarygodnieniem był ceremoniał, w którym biskup namaszcza nowego monarchę. Zasada legitymizacji władzy wymaga udziału społeczeństwa w procesie wyznaczania rządzących. To chroni elity polityczne przed zarzutem uzurpacji. Jak zaznacza Andrzej Waśkiewicz, potrzeba posiadania audytorium różni reprezentację współczesną od średniowiecznej ${ }^{8}$. Bóg z uwagi na swoje atrybuty nie potrzebował namiestnika na ziemi. To władcy wykorzystywali go do legitymizowania swoich rządów. Współcześnie legitymizacja władzy kryje w sobie kolejną wątpliwość dotyczącą reprezentacji. „Za sprawą instytucji reprezentacji lud staje się więc rządzonymi ludźmi [...]"”. Jak dowodził już Jean-Jacques Rousseau, w dziedzinie politycznej reprezentowanie oznacza sprawowanie nad kimś władzy. Kwintesencją nowożytnej reprezentacji jest zatem to, że naród wybiera osoby, które będą nim rządzić. Reprezentanci nie ponoszą realnej odpowiedzialności przed ludem ${ }^{10}$. Mimo to sprawują władzę nad nim i w jego imieniu. Brakuje trzeciej strony zdolnej do wymuszania właściwego sprawowania swojej funkcji. Reprezentacja nie gwarantuje więc jakości sprawowanych rządów.

\section{Suwerenność ludu?}

Nie tylko legitymizacja budzi wątpliwości dotyczące współczesnej reprezentacji. Również kwestia suwerenności znacząco różni współczesną władzę suwerena od tego postrzeganego w sposób tradycyjny. Jak powiedziano, nominalnym suwerenem zawsze jest naród. Faktyczny mandat sprawują władze wybierane w wyborach. W demokratycznym systemie politycznym obowiązuje zasada wolnego mandatu. Jest to przeciwieństwo mandatu imperatywnego, w którym reprezentant jest przedstawicielem jedynie ludności, która go wybrała $^{11}$. Posiadając mandat powiązany z okręgiem wyborczym, posłowie i senatorowie są prawnie związani ze swoimi wyborcami, a także mogą być przez nich odwołani. Wyklucza to uzależnienie reprezentantów od grupy wyborców. Dzięki temu mogą (a nawet niekiedy powinni) głosować niezgodnie z wolą wyborców, ale dla ich dobra. Dlatego suwerenność narodu jest jedynie formalna i kończy się w momencie wyboru władz.

7 J. Barbey, Légitimité et légalité, „Feuille d'Information Légitimiste” 1993, nr 112/113, s. 2.

${ }^{8}$ A. Waśkiewicz, Paradoksy idei reprezentacji politycznej, Wydawnictwo Naukowe Scholar, Warszawa 2012, s. 274.

9 Tamże, s. 274.

${ }^{10}$ Zob. J. Gastil, By Popular Demand. Revitalizing Representative Democracy through Deliberative Elections, University of California Press, Berkley-Los Angeles-London 2000, s. 32-67.

${ }^{11} \mathrm{~K}$. Gajewski, Odpowiedzialność postów i senatorów na tle zasady wolnego mandatu, Wolters Kluwer, Warszawa 2009, s. 28-38. 
Ponadto w wyjątkowych sytuacjach rządzący mogą zawiesić tę relację - rządzący mogą użyć przemocy wobec ludu. Powoduje to dwojakie konsekwencje: po pierwsze, czy rządzący mogą podejmować decyzje wbrew woli większości dla dobra wspólnego oraz czy i w jakich sytuacjach władza może wykorzystywać przemoc bezpośrednią wobec obywateli. W przypadku suwerenności ludu zwłaszcza ta druga kwestia wywołuje kontrowersje. Konstytucje dokładnie opisują sytuacje, w których rządzący mogą wykorzystać siłowe rozwiązania wobec ludu. Nie wszystkie wydarzenia można łatwo sklasyfikować. Jak rozróżnić, czy władza działa dla dobra ogółu (w celu przywrócenia porządku), a nie dla utrzymania własnej pozycji? Zwłaszcza gdy demokracja dopuszcza nieposłuszeństwo obywatelskie jako formę kontroli nad rządem ${ }^{12}$. Według Benjamina Constanta obroną przed nadużyciami władzy miała być komunikacja na linii reprezentant-lud ${ }^{13}$. I to nie tylko poprzez wybory, ale głównie poprzez petycje, protesty, publikację oraz kontrolę mediów. Pierre Rosanvallon nazwał to demokracją negatywną ${ }^{14}$. Kultura polityczna polegająca na demokracji negatywnej opiera się na braku zaufania do delegatów (polityków), którzy uprawiają politykę opartą na resentymencie i kontestacji dotychczasowych zasad. Również Alexis de Tocqueville uważał, że samo wprowadzenie instytucji reprezentacji nie rozwiąże problemu dążenia rządzących do zawłaszczania władzy. Wręcz przeciwnie, dla niego podstawą demokracji był społeczny wymiar ustroju, a nie jego instytucje ${ }^{15}$. Zgodnie z zasadami reprezentacji władza w określonych sytuacjach może więc przemocą przywrócić porządek, jednocześnie lud może wypowiedzieć posłuszeństwo władzy.

\section{Jak pogodzić interesy wszystkich?}

Kolejny problem, jaki napotykamy przy rozważaniu idei rządów ludu, związany jest z odmiennymi interesami. Zadaniem rządu jest realizacja programu i działanie na rzecz ludu. Jednocześnie opozycja powinna ograniczać władzę i utrudniać w celu ochrony mniejszości. Jest to jednak utopia, gdyż każda partia dąży do maksymalizacji swojego poparcia, co może się wiązać z lekceważeniem woli mniejszości. Jak zauważył John Stuart Mill, reprezentanci nie są reprezentantami ludzi, ale jednostek geograficznych: „Nie widzę, dlaczego [...] ludzie mający różne interesy i inne uczucia, o które im bardziej chodzi aniżeli o interesy geograficzne, mieliby być ograniczeni do tych interesów jako jedynej zasady ich politycznej klasyfikacji”"16. Połączenie tych trzech lojalności (wobec systemu, wyborców oraz regionu) pozostaje niezmiernie trudne.

Powyższe wątpliwości reprezentacji opierały się na przekonaniu, że władza działa dla dobra wspólnego rządzonych. Czym ono jest? Zgodnie z teorią demokracji jest to wola

12 Zob. H. Arendt, Niepostuszeństwo obywatelskie, [w:] tejże, O przemocy. Niepostuszeństwo obywatelskie, Fundacja Aletheia, Warszawa 1998.

13 B. Constant, Zasady polityki mające zastosowanie do wszystkich rządów, Fundacja Res Publica im. H. Krzeczkowskiego, Warszawa 2008, s. 289.

${ }^{14}$ D. Runciman, M. Brito Vieira, Reprezentacja, Wydawnictwo Sic!, Warszawa 2011, s. 65.

15 A. de Tocqueville, O demokracji w Ameryce, Państwowy Instytut Wydawniczy, Warszawa 1976, s. 644.

16 J.S. Mill, O rzadzie reprezentatywnym. Poddaństwo kobiet, Społeczny Instytut Wydawniczy Znak, Kraków 1995, s. 146. 
większości, a nie jej reprezentantów lub innych osób roszczących sobie prawo mówienia w imieniu ludu. Jacek Raciborski wyróżnia cztery kategorie postulatów wysuwanych przez lud. Do pierwszej grupy należą oczekiwania socjalne - zapewnienia opieki zdrowotnej, dostępu do mieszkań czy świadczeń dla bezrobotnych. Druga grupa dotyczy szeroko pojętej kontroli rynków oraz zaangażowania w gospodarkę. Zgodnie z tymi postulatami ludzie chcą, by państwo angażowało się na przykład w ratowanie zakładów przemysłowych. Trzecia grupa odnosi się do działań mających na celu konsolidację społeczeństwa. Ostatnia grupa wiąże się z zapewnieniem pełnej partycypacji obywateli w życie państwa. Każde z tych żądań wobec państwa jest popierane przez różny odsetek obywateli. Największe, około 90-procentowe poparcie, dotyczy pierwszej oraz drugiej grupy, najmniejsze, około 70-procentowe, dotyczy czwartej ${ }^{17}$. Jednocześnie najważniejszym zobowiązaniem państwa wobec obywateli pozostaje konieczność zapewnienia bezpieczeństwa i porządku. Dlatego rozważając kwestie „wspólnego dobra obywateli”, należy pamiętać, że to właśnie reprezentanci podejmują decyzje, czy i jak wsłuchiwać się w głos obywateli. Najczęściej politycy uważają, że poprzez wybór ich partii wyborcy akceptują realizację ich wizji polityczno-społecznej.

Prowadzi to do przekonania, że posłowie powinni kierować się zarówno wolą ludu, jak i wspólnym dobrem. Niekiedy są to dwie przeciwstawne idee. Rodzi się pytanie, czy posłowie stanowią elitę intelektualną społeczeństwa, czy są jedynie biernym wykonawcą woli narodu. Jeżeli posłowie są wykonawcą woli suwerena, a więc społeczeństwa, wówczas demokracja oznaczałaby rządy większości nad mniejszością. Jeśli uznać posłów i rząd za elity intelektualne, kluczowe staje się dobro narodu, a nie większości. Rozwiązuje to dylemat lojalności, co jednocześnie oznacza możliwość każdorazowego rozstrzygania, kto ma rację - wyborcy czy partia (a może nikt). Takim rozumowaniem kierowali się twórcy demokracji. Prowadzi to do innych problemów demokracji. Po pierwsze, deputowani nie muszą trzymać się instrukcji, co powoduje, że wybrany przez obywateli program niekoniecznie jest realizowany. J.S. Mill uważał, że nie jest to sprzeczne z zasadami demokracji, gdyż reprezentanci w takim wypadku powinni wytłumaczyć i uzasadnić swoje osądy, a przez to przekonać elektorat. Podkreślał tym samym edukacyjną rolę parlamentu. Posłowie jako intelektualna elita powinni przekonywać ludzi i tłumaczyć im, co jest dobre dla całego państwa ${ }^{18}$. Z tego wynika drugi problem demokracji, który zauważał również Mill. Otóż nie istnieją wyraźne dowody, iż wyborcy kierują się racjonalnością i spośród kandydatów wybierają takiego, którego uważają za lepszego od siebie. Wręcz przeciwnie: często o wyborze kandydata decydują inne kwestie, takie jak: identyfikacja partyjna, kampania wyborcza czy ideologia ${ }^{19}$.

17 J. Raciborski, Obywatelstwo w perspektywie socjologicznej, PWN, Warszawa 2011, s. 266-270.

18 J.S. Mill, dz. cyt., s. 203.

19 K. Korzeniowski, Psychospołeczne uwarunkowania zachowań wyborczych, [w:] K. Skarżyńska (red.), Psychologia polityczna, Zysk i S-ka, Poznań 1999, s. 199-215. 


\section{Rola partii politycznych}

To prowadzi do ostatniej wątpliwości reprezentacji. Jest to instytucja zawłaszczona przez partie polityczne. Według A. de Tocqueville’a demokracja jest realizowana poprzez stowarzyszenia i organizacje. Instytucje sprawujące władzę nie są jedynymi przedstawicielami zdolnymi reprezentować interes społeczny (chociaż z całą pewnością odgrywają dominującą rolę). Wola ludu może być kreowana poprzez stowarzyszenia czy organizacje, z którymi elity muszą się liczyć. Konieczność istnienia takich form aktywności obywatelskiej obnaża ostatni słaby punkt reprezentacji. System nie może włączyć i wyartykułować żądań wszystkich grup społecznych. Co więcej, decyzje podejmowane są przez grupy najbardziej aktywnych obywateli (którzy działają w ramach systemu partyjnego lub poprzez stowarzyszenia). Demokracja nie ma zdolności do reprezentowania interesów pasywnych obywateli - nawet jeżeli stanowią oni większość. Może to powodować niezadowolenie czy rozczarowanie demokracją. Jedynym sposobem, by system poprawnie „działał”, jest chęć partii do agregowania interesów jak najszerszych grup obywateli - nawet jeżeli pozostają oni pasywni.

Max Weber zauważył, że paradoksalnie struktura reprezentacji, oparta na przekonaniu o wyższości intelektualnej reprezentantów, podziale geograficznym oraz nieograniczona na podstawie kazusów majątkowych czy etnicznych, spowodowała, iż polityka stała się bardziej zbiurokratyzowana, zmechanizowana oraz powodowana partykularnymi interesami partii. Dzięki temu partie stały się efektywniejsze i lepiej mogły wyrażać wolę obywateli. Machiny partyjne umożliwiły takim przywódcom, jak Abraham Lincoln dojście do władzy. Aparat partyjny stał się tym samym ważniejszy od poszczególnych osób. Demokracje nie są już walką pomiędzy różnymi kandydatami na posłów, ale potyczką partii, w której są poszczególni ludzie. Pretendenci zarazem czerpią zaufanie z faktu bycia członkiem danej formacji, ale również mogą wpływać na prestiż całej formacji. Wraz z rozwojem parlamentaryzmu partie zaczęły postrzegać siebie jako jedynego reprezentanta społecznych interesów. Już nie poszczególni ludzie, ale partie stały się uosobieniem reprezentacji interesów obywateli. Formalnie to nie one są nośnikiem reprezentacji, ale konkretne osoby wskazane w procesie wyborczym!

\section{Coraz mniej woli ludu}

Od czasów pierwszych demokracji społeczeństwo zmieniło się w niewyobrażalny sposób. Współczesny wyborca to osoba, która dostęp do informacji zyskuje za pomocą smartfona, którego zawsze ma przy sobie. Rozwój technologii wytwarza coraz więcej obszarów, które nie podlegają ochronie instytucji. W ostatnich latach sporo kontrowersji narosło wokół działalności służb specjalnych. Wielu obserwatorów zastanawia się, jak bardzo fakt, że służby ingerują w prywatność obywateli (nawet jeżeli robią to w celu ochrony większości), jest zgodny z duchem demokracji ${ }^{20}$. Kontrola dokonywana przez

${ }^{20}$ M.in. I. Krastew, Demokracja nieufnych. Eseje polityczne, Wydawnictwo Krytyki Politycznej, Warszawa 2013, s. 49-54. 
odpowiednich ministrów oraz komisje parlamentarne uważana jest za niewystarczającą, gdyż odbywa się bez nadzoru społecznego. Fakt, że społeczeństwa w coraz mniejszym stopniu ufają reprezentantom i instytucjom, tylko pogłębia dylemat dotyczący służb. Możliwości technologiczne sprawiają, że to, co kilka lat temu wydawało się dziedziną science-fiction, staje się rzeczywistością. Drugim problemem jest działalność mediów, określanych mianem czwartej władzy. Problemem mediów w demokracji jest brak kontroli nad nimi, zwłaszcza że społeczeństwo coraz częściej czerpie informacje z internetu (blogów, forów internetowych etc.). „[...] ludzie często nie są niedoinformowani na temat danej polityki, [...] ale celowo wprowadzani w błąd, są dezinformowani. Ludzie posiadają błędne informacje, ale są jednocześnie pewni, iż są one prawdziwe niezależnie od wskazówek płynących z otoczenia, że tak nie jest. Zatem problemem, przynajmniej w odniesieniu do postaw na temat polityki, nie jest to, że ludziom po prostu brakuje informacji, ale to, że trzymają się mocno błędnych informacji i używają ich do tworzenia swoich preferencji"'21. Badacze podkreślają, że współcześnie ludziom łatwiej niż kiedykolwiek żyć w „komorach pogłosowych"22 i dopuszczać do siebie tylko takie informacje, które korelują z ich światopoglądem ${ }^{23}$. Mimo tych argumentów demokracja nadal potrzebuje współistnienia rządów i wyborców.

\section{Oddajmy ludowi władzę!}

Na fali roszczeń o urealnienie władzy ludu coraz większą siłą stają się ruchy populistyczne. Popularność ruchów populistycznych obudziła demony nacjonalizmu, demagogii, oportunizmu czy komunizmu. Jednak w debacie politologicznej i socjologicznej pojawia się coraz więcej głosów mówiących, że ruchy antyelitarne mogą przysłużyć się demokracji. Celem populistów jest powrót do prawdziwej demokracji. Nawołują oni do marzenia o prawdziwej demokracji. Oferują odbudowanie wspólnoty i dumę z przynależności do niej. Jednocześnie twierdzą, że jedyny konflikt społeczny przebiega na linii lud-elity. Tym samym rozłamy socjopolityczne i konflikty schodzą na dalszy plan.

Siłą populistów jest ich zdolność wsłuchiwania się w ludzkie emocje. Widzą to, czego inne partie nie dostrzegają: lęki, rozczarowanie, frustracje. Przedstawiają siebie jako jedyne organizacje zdolne do zmiany liberalnego dyskursu. Ruchy te mają stanowić odnowę polityki i państwa. Co istotne, upraszczają świat i sprawiają, że staje się on zrozumiały dla odbiorcy. Niestety obraz ten jest znacząco uproszczony. Wyjście Wielkiej Brytanii z Unii Europejskiej nie naprawi służby zdrowia, nie podniesie emerytur ani nie zmieni rynku pracy, jak obiecywali eurosceptycy. Populizm odwołuje się do mitu złotego wieku, w którym to, co było kiedyś, jest lepsze, ładniejsze i prostsze. Jednak demokracja, o jakiej mówią populiści, nigdy nie istniała. Zawsze był to system oparty na reprezentacji, a lud

21 J.H. Kuklinski, P.J. Quirky, Misinformation and the currency of democratic citizenship, "Journal of Politics" 2000, 62(3), s. 792.

${ }^{22}$ R. Markowski, M. Cześnik, M. Kotnarowski, Demokracja, gospodarka, polityka. Perspektywa polskiego wyborcy, Wydawnictwo Scholar, Warszawa 2015, s. 57.

23 Tamże, s. 57. 
nie sprawował prawdziwej władzy. Na kanwie gniewu, straconej nadziei i spadającego zaufania do elit nie dziwi wzrost znaczenia populistów, którzy oferują ludziom nierealny powrót do ery sprzed globalizacji, niewyobrażalny wzrost gospodarczy czy bogate rozdawnictwo.

„Skoro odbywają się wybory i istnieje wolna prasa, można dany system nazwać demokracją. Zbyt wielu obserwatorów, posługujących się minimalistyczną definicją demokracji, ma tylko tyle do powiedzenia. Jeżeli jednak pojmujemy demokrację jako coś więcej niż same zasady proceduralne, jako ,inkluzywny” system [...] - gdzie wszyscy obywatele są prawowitymi członkami wspólnoty, a ludzie pracy włączeni są w system gospodarczy dzisiejsza Polska jest systemem mało demokratycznym. Przy nawracającej tendencji do wykluczenia przeciwników ze wspólnoty oraz systematycznej erozji społecznych praw ludzi pracy postkomunistyczna Polska nigdy nie była szczególnie liberalna ani szczególnie inkluzywna"24. Konieczność dostosowania się polityków do medialnej rzeczywistości sprawia, że polityka staje się coraz bardziej bieżąca i zunifikowana. Wymiana rządu najczęściej nie powoduje zmiany polityki. Rodzi to przekonanie, że partie polityczne różnią jedynie personalne spory, a nie faktyczne wizje polityki.

Dla populistów zmiana oznacza personalne roszady, dopuszczenie do systemu ,świeżej krwi”, ludzi z nowymi pomysłami, ideałami. Jednak nie jest to reforma ustroju, a raczej wybieg marketingowy. „Rozwiewanie wyborczych złudzeń nie musi oznaczać wyznawania spiskowej teorii dziejów. Nie musi też być obnażaniem cynizmu i pokazywaniem «prawdziwego oblicza» polityków zabiegających o poparcie mas za pomocą manipulacji. Ukryte mechanizmy nie muszą czemuś służyć. Mogą być niezamierzonym efektem naiwności ustawodawców, którzy - choć kierowali się szlachetnymi pobudkami - nie zauważyli, że wypuszczają z butelki dżina partykularyzmu i małostkowości. [...] nasze polityczne piekiełko jest wybrukowane właśnie takimi dobrymi chęciami. Rozwiązania o jasnych i czytelnych założeniach stworzyły ponury labirynt interesów - tych osobistych i instytucjonalnych. Każdy angażujący się w politykę, choćby sam był przepełniony idealizmem, wychodzi z tego labiryntu odmieniony" 25 . Dla przeciwników populistów problemem jest tabloidyzacja współczesnej polityki.

\section{Demokracja to faktycznie władza ludu?}

Idea reprezentacji od początku budziła zastrzeżenia. Przez wielu była i jest traktowana raczej jako zło konieczne, a nie ideał demokracji. A. Waśkiewicz w książce Paradoksy idei reprezentacji politycznej pisze ,[...] logika demokracji i logika reprezentacji nie przystają do siebie w pełni. Nawet jeżeli współczesna demokracja nie może mieć charakteru innego niż przedstawicielski, to reprezentacja [...] nie sprzyja bynajmniej jej „,demokratyzacji”; jeśli jej nie zatrzymuje, to przynajmniej spowalnia. Z perspektywy hiperdemokratycznej

${ }^{24}$ D. Ost, Klęska ,Solidarności”. Gniew i polityka w postkomunistycznej Europie, Wydawnictwo Muza, Warszawa 2007, s. 380.

25 J. Flis, Zludzenia wyboru. Społeczne wyobrażenia i instytucjonalne ramy w wyborach do sejmu i senatu, Wydawnictwo Uniwersytetu Jagiellońskiego, Kraków 2014, s. 7. 
trudno zatem reprezentację wychwalać, można się z nią pogodzić jako ze złem nieuniknionym" 26 . Wszystkie powyższe wątpliwości mogłyby prowadzić do wniosku, że tron władzy w demokracjach jest pusty, gdyby nie fakt, że twórcom systemu zależało na tym, by faktyczna władza była sprawowana przez lud.

Federaliści uważali, że źródłem niepowodzenia każdego z systemów byli ludzie - zarówno ci sprawujący władzę, jak i zwykli obywatele. Za Thomasem Hobbesem i Johnem Locke’em uważali, że człowiek z natury jest zły i egoistyczny. „Każda władza deprawuje, a władza absolutna deprawuje absolutnie"27. Dlatego rządy republikańskie ${ }^{28}$ musiały być odporne na czynnik ludzki. Ktokolwiek zasiada na tronie (monarcha, rząd czy nawet całe społeczeństwo), musi być kontrolowany. „To może być zbyt wielka pokusa dla ludzkiej słabości, skłonnej skorzystać z danej jej władzy"29. Rozwiązaniem okazały się procedury prawne i instytucje państwa prawa, które opierają się na rozdzieleniu władzy pomiędzy różnych ludzi oraz instytucje, tak aby wzajemnie się kontrolowały, a także ograniczały swoją władzę. Podstawą myśli liberalnych demokratów jest stała i niesłabnąca nieufność w stosunku do ludzi. Wyraża to David Hume w słowach: „Pisarze polityczni, powołując jakikolwiek system władzy, tworząc system kontroli i instytucji czuwających nad przestrzeganiem konstytucji, uczynili swą maksymą to, że każdy człowiek musi być traktowany jak ewentualny niegodziwiec, którego działaniem kieruje jedynie korzyść własna"30. Społeczeństwo jako całość sprawuje władzę zwierzchnią, ale jego władztwo „[...] powinno kończyć się wraz z przyjęciem konstytucji” ${ }^{31}$. Ludzie jako naród nie mogą działać, dyskutować i rozwiązywać problemów wspólnie.

\section{Do kogo należy władza w demokracjach?}

Podstawą koncepcji demokracji opracowanej przez ojców demokracji - Monteskiusza, Jamesa Madisona, Thomasa Jeffersona czy innych twórców koncepcji demokracji jest założenie, iż ludźmi kieruje „[...] miłość do władzy i miłość do pieniądza"32. Podobnie jak $\mathrm{u}$ Arystotelesa celem ustroju jest stworzenie takiej koncepcji, która nie ulegnie degradacji. Idealna demokracja według Madisona i innych federalistów to system, który najlepiej zabezpiecza wolność przed tyranią. Zatem nie jest to system, który najlepiej wyraża wolę ludu ${ }^{33}$. Demokracja madisonowska opiera się na przekonaniu, że władzę należy rozdzielić pomiędzy różne instytucje i ludzi, z jednoczesnym zachowaniem zwierzchniej roli społeczeństwa, sprawowanej za pomocą cyklicznych wyborów. 51. list federalistów

\footnotetext{
${ }^{26}$ A. Waśkiewicz, dz. cyt., s. 13.

27 Lord Acton (John Emerich Edward Dalberg-Acton), Letter to Bishop Mandell Creighton, 1887.

28 Federaliści uważali się właśnie za republikanów, a nie demokratów.

29 R. Hardin, Zaufanie, Wydawnictwo Sic!, Warszawa 2009, s. 147.

30 Tamże, s. 146.

31 Tamże, s. 148.

32 Wypowiedź B. Franklina podczas konwencji konstytucyjnej, za: R.A. Dahl, Demokracja i jej krytycy, Wydawnictwo Aletheia, Warszawa 2012, s. 8.

${ }^{33}$ W 63. liście federalistów J. Madison stwierdził, że zadaniem rządu nie jest artykułowanie potrzeb wyborców, ale wprowadzanie niepopularnego prawa dla dobra ogółu. J. Madison, Federalist No. 63. The Senate Continued, http://www.gutenberg.org/files/1404/1404-h/1404-h.htm\#link2H_4_0063 [dostęp: 23.04.2019].
} 
stwierdza: „Ambicję należy przeciwstawiać ambicji”34. Odzwierciedla to podział władzy zaproponowany przez Monteskiusza, który zakłada wzajemne kontrolowanie się wszystkich trzech władz: ustawodawczej, wykonawczej i sądowniczej. Obecnie wszystkie państwa dążą do uwzględnienia w swoich systemach trójpodziału władzy. Prócz tyranii elit systemowi zagraża również tyrania większości. Podkreśla to William H. Riker, który uważa, że trójpodział władzy chroni system przed tyranią większości. Zdaniem badacza podział władz można rozumieć statycznie, wówczas oznacza on podział władzy na różne gałęzie, które współrządzą jednocześnie i wzajemnie się kontrolują. Drugim sposobem zrozumienia jest podział dynamiczny, a więc rozłożony w czasie. Cykliczne wybory zapobiegają utrzymaniu się jednej większości przez wiele kadencji ${ }^{35}$. Oba podziały mają zapobiegać tyranii większości.

Drugim kluczowym mechanizmem są wybory. W.H. Riker podkreśla, że to wybory stanowią ochronę przed tyranią urzędników i polityków. „Podstawowym założeniem demokracji jest podejrzliwość wobec każdej władzy. Demokracja wymaga uzasadnienia wszelkiej władzy, którą per se uznaje się za podejrzaną"36. Żaden rząd ani władca nie otrzymuje dożywotniej legitymizacji ${ }^{37}$. Źródłem władzy jest wola społeczeństwa wyrażona w czasie cyklicznych, wolnych, równych, powszechnych i tajnych wyborów. Z wyborami połączony jest inny, nie mniej ważny, mechanizm zinstytucjonalizowanej nieufności. Każde państwo musi opierać się na pluralizmie politycznym. Demokracja nie może istnieć bez dyskusji, refleksji czy kompromisu. Istnienie wielu reprezentujących odmienne poglądy i konkurujących ze sobą partii jest warunkiem niezbędnym ustroju demokratycznego.

Kwintesencją trzeciego mechanizmu zinstytucjonalizowanej nieufności jest przekonanie, że zarówno ludzie władzy, jak i społeczeństwo są równi wobec prawa. Sądy w demokracjach liberalnych muszą być niezależne i niezawisłe. Innym przykładem mechanizmów nieufności jest administracja. Politycy kreują prawo, natomiast urzędnicy gwarantują, że jest ono wdrażane i stosowane.

Koncepcje Roberta A. Dahla czy W.H. Rikera nie zakładają, że demokracja jest systemem najlepiej realizującym „,wolę ludu”. W tym ujęciu jest to ustrój samoregulujący się i budujący zaufanie. Inaczej tę kwestię postrzega Sartori, dla którego kwintesencją demokracji jest jakość decyzji demokratycznych. Podstawą rozważań politologa są dwa kluczowe elementy, przekonujące, że demokracja jest ustrojem prowadzącym do dobrych rządów. Chad Walsh postrzega to jako kolejny element charakterystyczny dla utopii. Władcy mają być sprawiedliwi lub mają się nauczyć sprawiedliwości ${ }^{38}$. Po pierwsze, postanowienia polityczne zawsze dotyczą społeczności, co oznacza, że mają charakter skolektywizowany. Celem ustaw jest działanie dla kogoś. Drugą cechą decyzji jest kolegialność ich podejmowania. Demokratyczne ciała decyzyjne składają się z wielu osób.

\footnotetext{
${ }^{34}$ Tamże.

35 W.H. Riker, Liberalism against Populism, Freeman, San Francisco 1982, s. 10.

36 P. Sztompka, dz. cyt., s. 346.

37 Oczywiście można uznać, iż monarchie konstytucyjne są zaprzeczeniem tej zasady. Jednak współcześni monarchowie pełnią raczej reprezentacyjną rolę, nie posiadając faktycznej mocy sprawczej. Jednocześnie demokracja daje ludziom możliwość zmiany ustroju i ,likwidacji monarchii”.

${ }^{38}$ Ch. Walsh, From Utopia to Nightmare, Harper, London 1962, s. 80.
} 
Teoria G. Sartoriego zakłada istnienie innego rodzaju zaufania. W przypadku paradoksów demokracji celem ustroju było konstruowanie zaufania społecznego oraz do państwa i jego instytucji. Sartori podkreśla znaczenie zaufania do reprezentantów jako osób podejmujących kluczowe decyzje dla przyszłości grup społecznych. Pojawia się tutaj dwojakie ryzyko - po pierwsze, ustawy mogą nie odpowiadać „woli ludu”, a po drugie, mogą okazać się złe. Proces decyzyjny łączy się również z kosztami, które rosną wraz z wielkością ciał decyzyjnych. Innymi słowy - demokracja idealna to taka, która tak kreuje procedury, by minimalizowały ryzyko i koszty podjęcia decyzji.

Koncepcja G. Sartoriego odchodzi od tradycyjnego rozumienia polityki jako wojny na rzecz sposobu wypracowywania i realizowania wspólnych celów. Jednocześnie nie neguje istnienia konfliktów, ale widzi w nich pole do negocjacji i przetargów. W tym ujęciu demokracja to przede wszystkim droga do konsensusu i budowanie wokół niego szerokich koalicji.

\section{Podsumowanie}

„Rządy ludu, dla ludu, przez lud sprawowane” ${ }^{39}$ - nie mogą stanowić definicji demokracji. Jest to raczej zabieg retoryczny czy marketingowy, który pozwala na tworzenie nowych populistycznych ugrupowań. Ojcom założycielom demokracji zależało na tym, by system włączał lud w proces rządzenia. Formalna wola ludu ogranicza się do uczestnictwa czynnego i biernego w ramach systemu. Nie może jednak oznaczać formalnego zasiadania ludu na tronie władzy lub uzurpowania sobie pełni władzy przez reprezentantów To nie lud czy jego reprezentanci zajmują tron władzy. Zajmuje go prawo, gwarantujące demokrację, będącą niczym innym jak umową społeczną, która chroni społeczeństwa przed stanem natury. Wydaje się, że w XXI wieku bardziej niż kiedykolwiek fakt, że mityczny tron władzy zajmują procedury, a nie konkretni i namacalni ludzie, jest największą siłą systemu. Wiek XXI to czas, w którym ufamy systemom abstrakcyjnym przy jednoczesnym spadku wiary w ,żywego człowieka”, dlatego mechanizmy proceduralne sprawiają, że pomimo wszystkich wątpliwości dotyczących reprezentacji jest i będzie ona najważniejszą zasadą demokracji.

\section{Bibliografia}

Arendt H., Niepostuszeństwo obywatelskie, [w:] tejże, O przemocy. Niepostuszeństwo obywatelskie, Fundacja Aletheia, Warszawa 1998.

Barbey J., Légitimité et légalité, „Feuille d'Information Légitimiste” 1993, nr 112/113.

Bożyk S., Partie polityczne a Sejm RP, Wydawnictwo Sejmowe, Warszawa 2006.

Constant B., Zasady polityki majace zastosowanie do wszystkich rząów, Fundacja Res Publica im. H. Krzeczkowskiego, Warszawa 2008.

${ }^{39}$ A. Lincoln, dz. cyt. 
Dahl R.A., Demokracja i jej krytycy, Wydawnictwo Aletheia, Warszawa 2012.

Flis J., Zludzenia wyboru. Spoleczne wyobrażenia i instytucjonalne ramy w wyborach do sejmu i senatu, Wydawnictwo Uniwersytetu Jagiellońskiego, Kraków 2014.

Gajewski K., Odpowiedzialność postów i senatorów na tle zasady wolnego mandatu, Wolters Kluwer, Warszawa 2009.

Gastil J., By Popular Demand. Revitalizing Representative Democracy through Deliberative Elections, University of California Press, Berkley-Los Angeles-London 2000.

Hardin R., Zaufanie, Wydawnictwo Sic!, Warszawa 2009.

Korzeniowski K., Psychospoleczne uwarunkowania zachowań wyborczych, [w:] K. Skarżyńska (red.), Psychologia polityczna, Zysk i S-ka, Poznań 1999.

Krastew I., Demokracja nieufnych. Eseje polityczne, Wydawnictwo Krytyki Politycznej, Warszawa 2013.

Kuklinski J.H., Quirky P.J., Misinformation and the currency of democratic citizenship, "Journal of Politics" 2000, 62(3).

Lincoln A., Przemowa gettysburska, 19 listopada 1863, https://www.fold3.com/image/4346725 [dostęp: 16.03.2020].

Lord Acton (John Emerich Edward Dalberg-Acton), Letter to Bishop Mandell Creighton, 1887.

Madison J., Federalist No. 63. The Senate Continued, http://www.gutenberg.org/ files/1404/1404-h/1404-h.htm\#link2H_ 4 0063 [dostęp: 10.02.2020].

Markowski R., Cześnik M., Kotnarowski M., Demokracja, gospodarka, polityka. Perspektywa polskiego wyborcy, Wydawnictwo Scholar, Warszawa 2015.

Mill J.S., O rzadzie reprezentatywnym. Poddaństwo kobiet, Społeczny Instytut Wydawniczy Znak, Kraków 1995.

Ost D., Klęska ,, Solidarności”. Gniew i polityka w postkomunistycznej Europie, Wydawnictwo Muza, Warszawa 2007.

Pitkin H.F., The Concept of Representation, University of California Press, Berkeley-Los Angeles-London 1967.

Przemowa Gettysburska, Wikiźródła, https://pl.wikisource.org/wiki/Przemowa_Gettysburska [dostęp: 16.03.2020].

Raciborski J., Obywatelstwo w perspektywie socjologicznej, PWN, Warszawa 2011.

Riker W.H., Liberalism against Populism, Freeman, San Francisco 1982.

Runciman D., Brito Vieira M., Reprezentacja, Wydawnictwo Sic!, Warszawa 2011.

Sartori G., Teoria demokracji, Wydawnictwo Naukowe PWN, Warszawa 1998.

Sztompka P., Kapital społeczny. Teoria przestrzeni międzyludzkiej, Społeczny Instytut Wydawniczy Znak, Kraków 2016.

Tocqueville A. de, O demokracji w Ameryce, Państwowy Instytut Wydawniczy, Warszawa 1976.

Walsh Ch., From Utopia to Nightmare, Harper, London 1962.

Waśkiewicz A., Paradoksy idei reprezentacji politycznej, Wydawnictwo Naukowe Scholar, Warszawa 2012. 


\section{Streszczenie \\ Pusty tron władzy, czyli o dylematach władzy ludu w demokracjach}

W ostatnich latach politycy coraz częściej odwołują się do woli suwerena jako do motywatora podejmowania decyzji. W artykule została podniesiona kwestia wątpliwości kryjących się za zasadą reprezentacji - naczelną zasadą demokracji. To właśnie dzięki reprezentantom lud sprawuje władzę w państwach demokratycznych. I jak głoszą populiści, system trzeba zmienić, by przywrócić ludowi głos. Poruszono również kwestię realności takiego rozwiązania. Wybrani reprezentanci są jednocześnie podlegli ludowi i nim rządzą. Wywołuje to pytania o zakres władzy, jaką mają rządzący. Gdzie powinna kończyć się władza ludu oraz w jakich okolicznościach rządzący powinni wiedzieć lepiej niż vox populi? Zwłaszcza że współcześnie powstaje coraz więcej nisz, do których suwerenny lud nie ma dostępu.

Slowa kluczowe: reprezentacja, lud, demokracja

\section{Summary}

The empty throne of power: the dilemmas of peoples' authorities in a democratic system

During the last few years, politicians have increasingly referred to the will of 'the people' to justify their decisions. This article discusses the limits of the idea of representation, which is the main principle of democracy. In democratic countries 'the people' exercise their authority through representatives. According to populists, the democratic system needs to be changed to give voice to 'the people'. Elected representatives are both subordinate to 'the people' and govern them. This construction raises questions about the extent of power which representatives have. Where should the power of 'the people' end and in what circumstances should representatives know better than vox populi? Today there are many areas to which 'the people' have no access.

Keywords: representation, 'the people', democracy 


\author{
Anna Fligel (i) https://orcid.org/0000-0001-6272-5830 \\ anna.fligel@uni.lodz.pl \\ Uniwersytet Łódzki
}

\title{
Shmuel N. Eisenstadt w nowej odsłonie. Wokół książki Varieties of Multiple Modernities. New Research Design
}

Badania nad myślą Shmuela N. Eisenstadta (1923-2010), jak i te kontynuujące i rozwijające jego dziedzictwo, w tym adaptujące na szeroką skalę stworzoną przez niego teorię i metodologię, nieustannie przybierają na sile i to w najrozmaitszych zakątkach świata. Fakt ten nie może dziwić, skoro rezultaty jego własnych obszernych badań, prowadzonych intensywnie przez ponad pięćdziesiąt lat, uznawane są zazwyczaj - i bynajmniej nie tylko przez socjologów - za jeden z najważniejszych i najoryginalniejszych produktów w dziedzinie socjologii, dodałabym również: filozofii cywilizacji oraz filozofii kultury, jak i filozofii polityki i społeczeństwa drugiej połowy XX i początku XXI wieku. Warto od razu zauważyć, że w Polsce autor ten wciąż jest słabo znany, a badań krytycznych nad jego spuścizną nie prowadzi się w ogóle ${ }^{1}$. Wskazane przesłanki skłoniły mnie do napisania niniejszego tekstu, który w założeniu ma być artykułem przeglądowym jednej z nowszych książek pisanych z perspektywy teorii Shmuela N. Eisenstadta, zatytułowanej Varieties of

\footnotetext{
${ }^{1} \mathrm{Na}$ język polski zostało przełożone w całości tylko jedno dzieło z niezwykle bogatej spuścizny Eisenstadta, zob. Sh.N. Eisenstadt, Utopia i nowoczesność. Porównawcza analiza cywilizacji, Oficyna Naukowa, Warszawa 2009. Ponadto można znaleźć zaledwie kilka artykułów autorstwa Eisenstadta przełożonych na język polski: Nowoczesność ma wiele twarzy, Szmuel Eisenstadt; (wywiad) rozmowę przeprowadził Adam Leszczyński, XI 2005, „Gazeta Wyborcza” 2005, nr 258, s. 19; Sh.N. Eisenstadt, Etyka protestancka a nowoczesność - Weber i poza Weberem. Analiza porównawcza, tłum. Maria Bucholc, „Kultura i Społeczeństwo" 2006, nr 3, s. 219-241. Jedyne obszerniejsze opracowanie myśli Eisenstadta polskiego autorstwa to komentarz do artykułu Etyka protestancka a nowoczesność - Weber i poza Weberem. Analiza porównawcza, napisany przez Jerzego Szackiego i Zdzisława Krasnodębskiego pt. Eisenstadt: wierny i niewierny uczeń Maxa Webera, „Kultura i Społeczeństwo” 2006, nr 3, s. 241-257.
} 
Multiple Modernities. New Research Design (dalej: Varieties). Celem naukowym niniejszego artykułu jest krytyczna prezentacja wybranych - najistotniejszych i najciekawszych moim zdaniem - wątków Varieties. Książka ta o tyle zasługuje na szczególną uwagę, że napisana jest przez znawców myśli Eisenstadta. To dzieło stanowi zarazem krytyczną i analityczną kontynuację jego teorii. Dodatkowym ważnym celem artykułu jest próba przybliżenia intelektualnych osiągnięć tego socjologa nie tylko przez pryzmat Varieties, ale też własnych badań przygotowawczych nad jego spuścizną ${ }^{2}$.

Varieties miało swój etap wstępny w postaci projektu pt. Globalization, Theory of Modernization, Multiple Modernities, realizowanego przez Proto Sociology, An International Journal and Interdisciplinary Research Project przy Uniwersytecie Goethego we Frankfurcie nad Menem ${ }^{3}$. W trakcie jego realizacji zebrano ekspertów w dziedzinie myśli Eisenstadta, wywodzących się z różnych dyscyplin naukowych, z różnych zakątków świata. Zostało postawione przed nimi trudne zadanie dotarcia do głębszego zrozumienia projektu zwielokrotnionych nowoczesności, tzn. takiego, które przekraczałoby analizę historyczną. Zasadniczym celem było zbadanie szerokich i wszechobecnych implikacji, jakie wynikają dla współczesnego świata w sferze komunikacji, porządku społecznego, przynależności społecznej, a w konsekwencji pojmowania tego świata właśnie jako zwielokrotnionych nowoczesności. Pojęcie zwielokrotnionych nowoczesności (multiple modernities) stanowi nie tylko radykalną transformację w sposobie pojmowania nowoczesności, ale w ogóle w sposobie patrzenia na współczesny świat. Elementem scalającym prezentowane badania była próba dostrzeżenia z różnych perspektyw tego, co należałoby uznać za novum w światowym społeczeństwie jako „społeczeństwie społeczeństw”. Badaniom przyświecało przekonanie, że zwielokrotnione nowoczesności, globalizacja oraz wyłanianie się nowych społeczeństw nie są zjawiskami między sobą niepowiązanymi, a już na pewno nie sprzecznymi ${ }^{4}$.

Efektem tej kilkuletniej pracy jest prezentowane tu dzieło zbiorowe, którego niewątpliwą wartością jest między innymi to, że ma charakter interdyscyplinarny, jak i to, że

${ }^{2}$ G. Preyer, M. Sussman (red.), Varieties of Multiple Modernities. New Research Design, ,International Comparative Social Studies” 2016, No. 33, Brill, Leiden-Boston. Spis treści: Introduction on Shmuel N. Eisenstadt's Sociology: The Path to Multiple Modernities, Gerhard Preyer, Michael Sussman; PART I. GLOBAL MODERNITIES: EXTRAPOLATION OF THE RESEARCH PROGRAM: 1. With and beyond S.N. Eisenstadt: Transglobality, Eliezer Ben-Rafael, Yitzhak Sternberg; 2. Multiple Modernities and the Theory of Indeterminacy: On the Development and Theoretical Foundations of the Historical Sociology of Shmuel N. Eisenstadt, Manussos Marangudakis; 3. Multiple Modernities and Globalization/Glocalization: A Comment on Eisenstadt, Roland Robertson; 4. The Multiple Modernities Debates as a Prospectus for Global Scholarship: More Opportunities Than Dead-Ends?, Barrie Axford; 5. Multiple Modernities in Modern Law and Legal Systems: Shmuel Eisenstadt's Grand Design and Beyond, Werner Krawietz. PART II. MULTIPLE MODERNITIES VIEW TO CONTEMPORARY SOCIETIES: 6. Multipolarity Means Thinking Plural: Modernities, Jan Nederveen Pieterse; 7. Multiple Modernities, 'East' and 'West', and the Quest for Universal Human Rights, Luis Roniger; 8. The Iranian Revolution: The Multiple Context of the Iranian Revolution, Mehdi P. Amineh, Shmuel N. Eisenstadt; 9. Thinking Multiples Modernities from Latin America's Perspective: Complexity, Periphery and Diversity, Judit Bokser Liwerant; 10. Alternative Modernities, Mark Jarzombek; por. http://www. brill.com/products/book/varieties-multiple-modernities.

${ }^{3}$ Por. G. Preyer, M. Sussman, Introduction..., [w:] tychże (red.), Varieties of Multiple Modernities. New Research Design, ,International Comparative Social Studies” 2016, No. 33, s. IX.

${ }^{4}$ Por. tamże. 
jej autorzy oprócz prezentacji wyników swoich konkretnych badań śmiało zarysowują perspektywy kolejnego trzeciego programu badawczego. Książka bowiem stanowi zasadniczo krytyczną kontynuację tzw. drugiego programu badawczego, którego kulminacyjny moment G. Preyer datuje na 2003 rok. Dodajmy, że zarówno w pierwszym (1986), jak i drugim projekcie uczestniczył sam Eisenstadt, będąc w istocie ich twórcą, jak i przewodnikiem. Obszerne Wprowadzenie do książki, autorstwa jej redaktorów - Gerharda Preyera i Michaela Sussmana - dostarcza szczegółowych informacji na temat wskazanej ewolucji, do której i ja, chociaż oczywiście skrótowo, poniżej się odniosę. Nie tylko Wprowadzenie, ale również wiele fragmentów z rozdziałów zawartych zwłaszcza w części pierwszej, dostarcza nam szczegółowych informacji na temat samej myśli Eisenstadta i wspomnianej ewolucji. Zwłaszcza dla czytelnika mniej obeznanego w myśli Eisenstadta jest to zapewne wartościowy wymiar tej książki.

\section{Pierwszy i drugi program badawczy: zmiana społeczna - teoria niedookreślenia - zwielokrotnione nowoczesności}

Zanim Eisenstadt rozpoczął swój kluczowy program badawczy skupiony wokół stworzonej przez siebie teorii zwielokrotnionych nowoczesności, w jego badaniach można wyróżnić przynajmniej dwa istotne etapy. Pierwszy (lata 60. XX wieku) stanowił komparatywną analizę instytucji, kolejny zaś (lata 70.) to porównawcza analiza cywilizacji. W tych etapach szczególnie ważna była metoda analizy konfiguracyjnej. Poczynając od Political Systems of Empires (1963), celem badań Eisenstadta były, po pierwsze, systemowy wymiar imperiów, indywidualny charakter struktur społecznych oraz instytucji, i po drugie, same procesy społeczne, które kształtowane są w jego przekonaniu przez zasady tych struktur oraz instytucji w celu podtrzymania systemowych granic imperiów. Aby sprostać temu wyzwaniu, Eisenstadt zastosował bardzo szczególną metodologię, a mianowicie analizę konfiguracyjną. Jest to metoda, która polega na badaniu istotnych cech struktury społecznej, instytucji oraz wzorcowych (modelowych) działań społecznych, które mają kształtować i określać od wewnątrz dany system społeczny. Postępując według tej metody, Eisenstadt najpierw odróżnił i skonceptualizował wzorzec społeczny (tj. konfigurację), następnie zbadał jego cechy istotne, aż w końcu poddał interpretacji jego wpływ na utrzymanie systemowych granic badanych imperiów ${ }^{5}$.

Ważnymi rezultatami tych badań były: określona teoria zmiany społecznej oraz koncepcja niedookreślenia (indeterminacy). Najwięcej informacji na ten temat dostarcza nam Manussos Marangudakis - autor drugiego rozdziału Varieties, zatytułowanego Multiple Modernities and the Theory of Indeterminacy: On the Development and Theoretical Foundations of the Historical Sociology of Shmuel N. Eisenstadt. Marangudakis podkreśla,

\footnotetext{
5 Por. M. Marangudakis, Multiple Modernities and the Theory of Indeterminacy: On the Development and Theoretical Foundations of the Historical Sociology of Shmuel N. Eisenstadt, [w:] G. Preyer, M. Sussman (red.), Varieties of Multiple Modernities. New Research Design, „International Comparative Social Studies” 2016, No. 33, s. 48. Por. także A. Fligel, Różnorodność w jedności? Krótki esej o Europie w świetle teorii zwielokrotnionych modernizacji Shmuela N. Eisenstadta, „Cywilizacja i Polityka” 2016, nr 15.
} 
że Eisenstadt, poczynając od swoich badań nad imperiami agrarnymi, przez późniejsze dotyczące osiowości (1986), nowoczesności (2002), aż po badania nad rewolucją (2006), zawsze był mocno zainteresowany zrozumieniem zagadnienia zmiany historycznej oraz opracowaniem solidnej socjologii historycznej ${ }^{6}$. Marangudakis nazywa teorię Eisenstadta teorią niedookreślenia i uznaje, że opierając się na niej, Eisenstadt rozwinął najbardziej radykalny historyczno-socjologiczny model mający na celu zrozumienie nowoczesności ${ }^{7}$.

Z badań nad zmianą społeczną wyłania się pogląd, że ,[...] możliwość innowacji oraz zmiany nie jest czymś zewnętrznym lub przypadkowym względem jakiegokolwiek porządku instytucjonalnego. To jest dane przez samą naturę procesu instytucjonalizacji oraz tego, w jaki sposób dany porządek instytucjonalny działa"s. Chodzi więc o tzw. endemiczny (lokalny) charakter zmiany społecznej, który należy rozumieć w ten sposób, że zmiana jest w dużej mierze warunkowana przez specyficzne, lokalne uwarunkowania ${ }^{9}$. Chciałoby się powiedzieć, że zmiana zawsze uzależniona jest od konkretnej szczegółowej sytuacji i miejsca. Eisenstadt uznaje, że główna przyczyna zmiany społecznej leży w ludzkim sprawstwie oraz aktywności, podkreślając rolę elit, które stanowią zarazem barierę, jak i inicjatorów owej zmiany. Przypomnijmy, że w jego teorii rozwój i krystalizacja tzw. cywilizacji osiowych możliwe były tylko dzięki wyłonieniu się nowego typu elit ${ }^{10}$.

W badaniu zmiany społecznej Eisenstadtowi w istocie chodziło o badanie strukturalnej ewolucji, „ewolucyjnego wyłaniania się społeczeństw [...] oraz formacji społecznych”"11. Kluczowe w tym względzie było poddanie ponownej ocenie strukturalno-funkcjonalnego podejścia w teorii socjologicznej autorstwa Talcotta Parsona. Eisenstadt przeciwstawiał się przede wszystkim jego teleologizmowi. Parson w interpretacji Eisenstadta przeceniał ukierunkowanie (celowość) oraz zbieżności (zgodności) jak na przykład w ewolucyjnej koncepcji uniwersaliów w społeczeństwie. Sam Eisenstadt położył nacisk na wielość i różnorodność form, które stanowiły cechy charakterystyczne zarówno epoki osi, jak i nowoczesności. Ponadto zwracał on uwagę na potencjał konwergencji oraz potencjał rozbieżności i niezgodności. Sądzę, że ta dialektyczna mieszanina, przy jednoczesnym odrzuceniu Parsonowskiego teleologizmu, stanowią klucz do zrozumienia istoty teorii zwielokrotnionych nowoczesności.

Drugą zasadniczą koncepcją, nad którą Eisenstadt pracował od samego niemal początku swojej naukowej działalności, jest teoria niedookreślenia. Jest ona ściśle związana z koncepcją zmiany społecznej, a ponadto obie one przygotowują grunt dla teorii zwielokrotnionych nowoczesności, a zarazem również będą stanowić jej istotne elementy. Zdaniem Eisenstadta niedookreślenie jest udziałem każdego aspektu ludzkiego życia organizacyjnego. Znajduje się ono w tzw. sferze pomiędzy: pomiędzy indywidualny-

6 Tamże.

7 Tamże.

${ }^{3}$ Sh.N. Eisenstadt (red.), Readings in Social Evolution and Development, Pergamon Press, Oxford 1970, s. 11, cyt. za E. Ben-Rafael, Y. Sternberg, With and beyond S.N. Eisenstadt: Transglobality, [w:] G. Preyer, M. Sussman (red.), Varieties of Multiple Modernities. New Research Design, „International Comparative Social Studies" 2016, No. 33, s. 33.

9 Tamże.

10 Por. Sh.N. Eisenstadt, Utopia ..., dz. cyt., s. 39-42, passim.

11 G. Preyer, M. Sussman (red.), dz. cyt., s. 15. 
mi i zbiorowymi aktorami społecznych interakcji, pomiędzy ich celami, pragnieniami osiągnięcia tych celów. Niedookreślenie znajduje się również w sferze najważniejszych zasobów: naturalnych i produkowanych, wymienianych i dystrybuowanych, ponieważ dostęp różnych aktorów do najważniejszych zasobów zasadniczo nie jest określony w obiektywny sposób, to znaczy jest on w pewnym sensie i w zasadniczym stopniu arbitralny. Świadomość tego typu niedookreślenia wzmaga kruchość oraz podatność na zmienność. I w tej perspektywie Eisenstadt przyznaje kluczową rolę elitom, które wypełniają ową otwartą przestrzeń pomiędzy: pomiędzy aktualnością a potencjalnością, tworząc i podtrzymując instytucje jako związek między podmiotem działania (agency) a struktura. Marangudakis uwypukla konkluzję Eisenstadta stwierdzeniem, że rozwój społeczny jest nie tylko jakimś prostym procesem wewnętrznego wzrostu i racjonalizacji, ale również niezamierzoną konsekwencją wysiłku elit do kontrolowania członków społeczeństwa, jak i kontrolowania dystrybucji wolnych zasobów ${ }^{12}$. Obydwa te czynniki odgrywają dużą rolę w określaniu społecznej komunikacji oraz w określaniu zadań i statusu społecznego poszczególnych jego członków ${ }^{13}$.

Procesualność rzeczywistości, jej ogromna złożoność, dialektyczny charakter, szczególna rola podmiotu działającego (agency), głównie w postaci elit (w szerokim rozumieniu tego słowa), oto mamy - jak sądzę - podwaliny dla teorii zwielokrotnionych nowoczesności. Z tej perspektywy Eisenstadt rozpoczął Pierwszy program badawczy. Socjologiczne podejście do cywilizacji porównawczych: rozwój oraz kierunek programu badawczego 1986 (Eisenstadt 1986, rep. 2007 ${ }^{14}$ ). Teoria zwielokrotnionych nowoczesności jako nowe, gdyż radykalne rozumienie nowoczesności u swojej podstawy stanowi odrzucenie głównych założeń strukturalnego funkcjonalizmu. Ów radykalizm polega między innymi na odrzuceniu założenia, że kultura, struktura społeczna i podmiot sprawczy są rzeczywistościami odrębnymi i z natury implikującymi wzrost, rozwój, różnicowanie się i specjalizację. Eisenstadt odrzuca również założenie, że dokonujący się w obrębie kultury, jak i struktury społecznej proces ma zasadniczo charakter rutynowy i racjonalny. Badania empiryczne Eisenstadta wskazują, że symboliczne i organizacyjne aspekty życia społecznego przeplatają się i że nawet jeśli stanowią analitycznie odrębne rzeczywistości, historycznie nie możemy rozumieć ich inaczej jak konstytutywnych elementów siebie nawzajem. Takie rozumowanie podważa ideę naturalnej ewolucji przednowoczesnych społeczeństw do nowoczesności, jak też „polityczne” rozumowanie, że Zachód stanowi nieuniknioną przyszłość wszystkich społeczeństw ${ }^{15}$.

Manussos Marangudakis w podsumowaniu swojego artykułu zauważa, że Eisenstadt w swojej koncepcji nowoczesności kładzie nacisk na dwie kwestie, które mają mieć kluczo-

12 M. Marangudakis, dz. cyt., s. 60-61.

13 Por. G. Preyer, M. Sussman (red.), dz. cyt., s. 17.

14 Por. Sh.N. Eisenstadt, Program of A Sociological Approach to Comparative Civilizations: The Development and Direction of a Research Program 1986, [w:] tegoż, Multiple Modernities - A Paradigm of Cultural and Societal Evolution, „Proto Sociology. An International Journal and Interdisciplinary Research” 2007, Vol. 24, s. 258-318. Część tej książki dostępna jest w internecie: http://www.protosociology.de/Download/ ProtoSociology-Vol24-Introduction.pdf [dostęp: 14.01.2020].

15 Por. M. Marangudakis, dz. cyt., s. 60. 
we znaczenie w empirycznych badaniach społecznych oraz teoretycznych jego analizach. „Po pierwsze, nie istnieje coś takiego jak przednowoczesne czy tradycyjne społeczeństwo lub zachowanie, które można by porównywać z takim czy innym społeczeństwem albo zachowaniem nowoczesnym. Nie istnieje także coś takiego jak pojedyncze tradycyjne ani pojedyncze nowoczesne zachowanie, nastawienie czy poznanie, jako że osiowe predyspozycje kulturowe wpływały na ontologiczne przesłanki interakcji społecznych na długo przed nadejściem nowoczesności. Każda osiowość (axiality) - cywilizacja osiowa, mimo wspólnej ogólnej cechy charakterystycznej w postaci istnienia rozziewu między porządkiem transcendentalnym a ziemskim, różni się bardzo od pozostałych. Dotyczy to szczególnie sposobu rozumienia pojęcia zbawienie, które - nieco upraszczając - w tradycji judaistycznej stosowano zamiennie z pojęciem postuszeństwo, w greckiej z pojęciem prawda, konfucjańskiej-harmonia, buddyjskiej-oderwanie, hinduskiej-oczyszczanie, chrześcijańskiej - odkupienie, a w muzułmańskiej z pojęciem uległość. Ta odmienność dotyczy zarówno sfery ontologicznej, jak i behawioralnych skutków. Ta różnorodność w koncepcji zbawienia doprowadziła do zaistnienia wielu odmiennych ontologicznych map i dalej do zaistnienia różnorodnych tradycjonalizmów, które należy badać i analizować raczej jako odrębne systemy społeczne niż jako proste przypadki przednowoczesności"16.

Marangudakis dostarcza nam również szczegółowego wyjaśnienia koncepcji zwielokrotnionych nowoczesności. Czytamy tam:

Idea ta głosi, że nowoczesność nie może być utożsamiona z Zachodem i jej powojenną drogą ku modernizacji. Nawet jeśli Zachód przez chwilę wydawał się prawdziwym nośnikiem nowoczesności, nie był nim, był tylko pierwszy, jeśli chodzi o samo powstanie tej epoki. [Przypomnijmy, że Eisenstadt datuje narodziny nowoczesności na XVII wiek $-\mathrm{AF}^{17}$ ]. W istocie, on sam, dzięki wewnętrznej dynamice ukształtował wiele na poły autonomicznych centrów społecznej dominacji, które otworzyły drogę do pełnego rozwoju fundamentalnych wartości i wizji nowoczesności, która z kolei za pośrednictwem imperializmu rozprzestrzeniła się na cały świat. I ponieważ modernizacja wiązała się z pewnymi trendami różnicowania strukturalnego w obrębie szerokiej gamy instytucji, co najpierw kształtowało się na Zachodzie (w ekonomicznych i politycznych rozwiązaniach, w urbanizacji i edukacji, w indywidualistycznym stylu życia), później jawił się on jako rzeczywisty agent nowoczesności. Szybko jednak okazało się, że adaptacja tych społecznych struktur i instytucji nie doprowadziła do połączenia się kultur czy kulturowych przesłanek, lecz do konstrukcji i rekonstrukcji wielości odrębnych kulturowych programów. Te rekonstrukcje instytucjonalnych i ideologicznych modeli kształtowane są przez poszczególnych aktorów w połączeniu z działaniami i ruchami społecznymi dążącymi do różnych programów nowoczesności, przy pomocy różnych reinterpretacji hegemonicznego programu kulturowego. To prowadziło do przekonania, że nowoczesność i Zachód nie są ze sobą tożsame. Nowoczesność jest natomiast odrębną cywilizacją, która nałożyła się na dziedzictwo epoki osiowej ${ }^{18}$.

16 Tamże, s. 63. Na temat cywilizacji osiowej odsyłam między innymi do tłumaczenia artykułu Eisenstadta z 1986 roku pt. The Origins and Diversity of Axial Age Civilisations, przekład polski: Sh.N. Eisenstadt, Epoka osiowa $w$ dziejach ludzkości, [w:] H. Joas, K. Wiegandt (red.), Kulturowe wartości Europy, Wydawnictwo IFiS PAN, Warszawa 2012, s. 35-57.

17 Por. Sh.N. Eisenstadt, Utopia ..., dz. cyt., s. 383-384.

18 M. Marangudakis, dz. cyt., s. 58-59. 
Sądzę, że ten element myśli Eisenstadta domaga się odrębnej szczegółowej analizy. Twierdzenie ogólne, że nowoczesność nie jest produktem ściśle związanym z kulturą zachodnią (i jej ewolucją) intuicyjnie wydaje się słuszne. Tym niemniej w zachodniej socjologii dominują tezy przeciwne. Bez wątpienia między innymi z tego powodu koncepcja Eisenstadta przez niego samego i przez autorów Varieties nazwana została radykalnie nową. Temu wątkowi intelektualnego dorobku Eisenstadta zamierzam poświęcić w przyszłości pogłębione badania i odrębny artykuł, również biorąc pod uwagę perspektywę postkolonialną.

Bardzo ciekawego komentarza do Eisenstadta teorii zwielokrotnionych nowoczesności dostarcza nam rozdział szósty, zatytułowany Multipolarity Means Thinking Plural: Modernities, autorstwa Jana Nederveena Pieterse'a. Jest on dlatego szczególnie ciekawy, że australijski badacz napisał go z perspektywy wydarzeń i zmian czasów najnowszych. Warto przytoczyć obszerny fragment ze wstępu i podsumowania tego rozdziału, by pokazać, w jaki interesujący sposób myśl Eisenstadta można zastosować jako narzędzie interpretacyjne. Czytamy tam:

Wielobiegunowość znaczy myśleć w liczbie mnogiej. Epoka Zimnej Wojny była bipolarna, zestawienie kapitalizm-komunizm przenikało wiele wymiarów rzeczywistości. Okres jednobiegunowości, który nastąpił po zakończeniu Zimnej Wojny, był jednym z przejawów relatywnie niepohamowanej ekspansji amerykańskiej super potęgi w zakresie kapitalizmu, finansów, a w końcu i geopolityki. To była epoka neoliberalizmu, Washington Consensus, powracających finansowych kryzysów w obrębie wschodzących gospodarek oraz, podczas administracji G.W. Busha, trzech nowych wojen. W całym tym procesie USA przeceniło swoje możliwości i uległo przeforsowaniu.

Wraz z dwudziestym pierwszym wiekiem wchodzimy w erę wielobiegunowości, ukształtowaną przez dwa wyznaczniki: osłabienie amerykańskiej hegemonii i wzrost znaczenia wyłaniających się społeczeństw. [...] nowe punkty odniesienia stopniowo wyłaniają się w Azji Wschodniej, Chinach, Singapurze, Zatoce Perskiej i Ameryce Lacińskiej. W międzynarodowym biznesie mówi się o ,rozszczepieniu”. W badaniach nad rozwojem mówi się o „Azjatyckich sternikach” (Asian drivers). Inwestorzy i menagerowie mówią o BRICu (Brazylia, Rosja, Indie, Chiny) i innych wschodzących gospodarkach [...]. $\mathrm{W}$ stosunkach międzynarodowych mowa zaś o ,wschodzeniu reszty" (the rise of the rest) (Zakaria 2008) oraz przejściu od G7 do G20 jako głównym forum w gospodarce światowej. Zaś prezes Banku Światowego wskazuje, że ,wielobiegunowa ekonomia, mniej zależna od amerykańskiego konsumenta, będzie bardziej stabilną ekonomią".

W tym układzie w pełni zasadne jest myślenie o nowoczesności w liczbie mnogiej, ponieważ wyłaniające się społeczeństwa nie są już dłużej w poczekalni historii: one stały się już aktorami na scenie głównej. Dobrym przykładem jest rola państwowych funduszy majątkowych z globalnego Południa jako finansowych graczy, zwłaszcza od 2007 roku. Ma to sens, ponieważ etykieta „państw rozwijających się” nie jest już adekwatna. Państwa takie jak Brazylia, Meksyk czy Indonezja nie są już po prostu państwami rozwijającymi się $[\ldots]^{19}$.

19 J.N. Pieterse, Multipolarity Means Thinking Plural: Modernities, [w:] G. Preyer, M. Sussman (red.), Varieties of Multiple Modernities. New Research Design, „International Comparative Social Studies” 2016, No. 33, s. 109. 
Zaś w podsumowaniu artykułu Pieterse pisze:

[...] nowoczesności są tematem naszych czasów. Uznanie, że nowoczesności jest wiele i że są różne oraz że przekraczają typ idealny nowoczesności, jest zarazem rozpoznaniem wielobiegunowości zglobalizowanej rzeczywistości XXI wieku, oraz rozpoznaniem „wyłonienia się reszty”. To wiąże się zarazem z rozpoznaniem, że nowoczesności są wymieszane oraz wielopoziomowe (layered), również na Zachodzie. Od nowoczesności jako utopii zostajemy więc przeniesieni do nowoczesności, która twardo stąpa po ziemi. To otwiera możliwość pogodzenia się z dylematami, którym rzeczywiste, aktualne nowoczesności muszą stawić czoła ${ }^{20}$.

Artykuł Jana N. Pieterse’a wydaje się swoistym hołdem złożonym ku czci Eisenstadta. Pieterse implicite głosi, że Eisenstadt miał niesamowicie głęboką intuicję rzeczywistości, skoro już na przełomie lat 70. i 80. XX wieku był w stanie sformułować teorię zwielokrotnionych nowoczesności, która ze swojej strony stała się znakomitym narzędziem interpretacyjnym historii u progu XXI wieku. Nawet jeśli ktoś ma wątpliwości co do interpretowania pierwszej dekady XXI wieku jako wielobiegunowej w sensie ścisłym czy w sensie pełnym, trudno nie zgodzić się z tym, że jednobiegunowość, jaka nastała po 1989 roku, uległa istotnemu załamaniu z końcem XX wieku, czego symbolicznym apogeum uznaje się często zamach z 11 września 2001 roku na World Trade Center w Stanach Zjednoczonych. Sądzę, że u progu trzeciej dekady XXI wieku, w jakiej obecnie się znajdujemy, teoria zwielokrotnionych nowoczesności jest jeszcze bardziej zasadna.

\section{Trzeci program badawczy: mapa semantyczna - studia globalne - transglobalność}

Zdaniem Gerharda Preyera „[...] socjologia ogólna Eisenstadta żąda dalszego opracowania skoncentrowanego na analizie mapy semantycznej jako ewolucyjnego uniwersum [...]". Jest to, zgodnie zresztą z założeniami samego Eisenstadta, konstytutywny i podstawowy punkt odniesienia badań nad społeczno-strukturalną ewolucją, który ma mieć zastosowanie do wszystkich społeczeństw.

Mapa semantyczna składa się zasadniczo z dwóch wymiarów (poles/dimensions): po pierwsze, rozróżnienia między działającym (Agency/creativity) a strukturą, i po drugie, związku kultura-struktura społeczna. Pierwszy biegun (wymiar) to rodzaj porządku kosmologicznego, stanowiący fundament kulturowej orientacji danego społeczeństwa i jego koncepcji przynależności, które obecnie ulegają głębokim przemianom na skutek globalnego rozprzestrzeniania się wzorców kulturowych i instytucjonalnych. Drugi wymiar, ściśle powiązany z pierwszym, to kwestia powstawania konfliktów i napięć w obrębie strukturacji, czyli wewnętrznej dynamiki wymiany społecznej, konfliktów i napięć generowanych w trakcie definiowania kosmologicznego porządku oraz jego symbolicznego znaczenia ${ }^{21}$.

20 Tamże, s. 121.

${ }^{21}$ G. Preyer, M. Sussman (red.), dz. cyt., s. 11. Por. także: G. Preyer, Zur Aktualität von Shmuel N. Eisenstadt. Eine Einleitung in sein Werk, Springer VS, Wiesbaden 2011. 
Gerhard Preyer to właśnie z zagadnienia mapy semantycznej chciał uczynić zwornik trzeciego programu badawczego, którego finalne opracowanie - warto dodać - znajdujemy w jego artykule z 2017 roku $^{22}$.

Kolejnym, kluczowym elementem w trzecim programie badawczym ma być rozwój tzw. studiów globalnych (global studies). Tą kwestię w Varieties podejmuje brytyjski politolog Barrie Axford, w rozdziale czwartym (zatytułowanym The Multiple Modernities Debates as a Prospectus for Global Scholarship: More Opportunities than Dead-Ends?). Artyku1 ten jest w istocie dyskusją z i wokół przedsięwzięć teoretycznych i metodologicznych Jana Nederveena Pieterse'a i jego tekstu z 2013 roku pt. What is global studies? ${ }^{23}$.

Pieterse w nadmienionym artykule skupił się na kwestii różnicy między badaniami nad globalizacją (globalization studies) a dziedziną o nazwie studia globalne oraz na pytaniu, dlaczego studia nad globalizacją są kontynuacją istniejących dziedzin wiedzy, natomiast studia globalne są czymś nowym. Pojęcie globalizacji - jak zauważa Pieterse - jest o wiele bogatszym intelektualnie i o wiele częściej stosowanym niż pojęcie globalność. Co jest oczywiste, skoro procesy globalizacyjne badane są od co najmniej trzydziestu lat, zaś globalność jako efekt tych procesów badana jest co najwyżej od parunastu lat. Tym niemniej sposób, w jaki badania nad globalizacją były i są prowadzone, nosi piętno poszczególnych nauk społecznych i humanistycznych. Przydatność badań nad globalizacją w istocie polega zatem na użyteczności w odniesieniu do tych dyscyplin. Natomiast sednem studiów globalnych (Axford uważa, że należałoby mówić o wiedzy globalnej-global scholarship) jest rosnące znaczenie ,czynnika globalnego” - the global ${ }^{4}$. Czytamy u Pieterse'a:

\begin{abstract}
Studia globalne odzwierciedlają rosnące znaczenie, cel i intensywność globalnych relacji i związków. Studia globalne rozrosły się ze względu na ogromny wzrost globalnych powiązań, globalnej dynamiki i globalnych problemów; są reakcją na rozgałęziające się, intensyfikujące, pogłębiające procesy globalizacyjne. Studia globalne rozprzestrzeniły się, ponieważ globalne stosunki i globalne problemy domagają się globalnego podejścia - potrzeba, która jest odczuwana przez siły społeczne, organizacje międzynarodowe, rządy i korporacje z całego świata ${ }^{25}$.
\end{abstract}

Jak zaś napisał w innej części cytowanego artykułu, ,[...] to, co globalne, i to, co powinno być rozumiane jako zagadnienia globalne, musi być postrzegane $\mathrm{z}$ różnych

22 Od około końca 2015 roku G. Preyer zaczął zajmować się szczegółowym opracowaniem wytycznych do trzeciego programu badawczego; zob. G. Preyer, Globalization and the Third Research Program of Multiple Modernities, dostępny: https://www.academia.edu/28292144/Gerhard_Preyer_Globalization_and the Third Research Program of Multiple Modernities [dostęp: 14.01.2020].

${ }_{23}$ J.N. Pieterse, What is global studies?, „Glabalizations” 2013, Vol. 10, 4, s. 499-515; dostępny również: https://nebula.wsimg.com/7728311b84f589fe8497af3191493ee6?AccessKeyId=FF8C6D6A9193E63EE 295\&disposition $=0$ \&alloworigin=1 [dostęp: 14.01.2020]. W związku z tym, że w Polsce taka dyscyplina jak studia globalne wydaje się niemal nieobecna, pozwalam sobie na pewne adnotacje bibliograficzne, jeśli chodzi o refleksję wokół postawionego przez Pietersa w tytule pytania. W trzech następujących numerach czasopisma „Globalizations” znajdują się artykuły na temat przedmiotowej kwestii: 2013, Vol. 10, 4; 2013, Vol. 10, 6 oraz 2014, Vol 11, 2.

${ }^{24}$ Por. B. Axford, The Multiple Modernities Debates as a Prospectus for Global Scholarship: More Opportunities Than Dead-Ends?, [w:] G. Preyer, M. Sussman (red.), Varieties of Multiple Modernities. New Research Design, „International Comparative Social Studies” 2016, No. 33, s. 73.

${ }_{25}$ J.N. Pieterse, What is global..., dz. cyt. 
perspektyw - północnej i południowej, wschodniej i zachodniej, narodowej i regionalnej, zbiorowej i indywidualnej [...]”, gdyż „[...] potraktować globalizację poważnie, w kategoriach poznawczych, emocjonalnych i wartościujących znaczy dostrzec różnorodność w ludzkiej kondycji w sposób globalny"26.

Pieterse (przytacza Axford) proponuje zatem, by:

- w badaniach globalnych iść ponad narodowy i międzynarodowy wymiar, aby wynieść globalny wymiar do rangi głównego punktu odniesienia i rozpoznać jednocześnie, że podmioty wiążą się z nim na różne sposoby i z różnymi dla siebie i dla środowisk społecznych skutkami,

- studia globalne mają mieć z konieczności multicentryczny charakter, stąd między innymi powinny obejmować swoim zasięgiem głębokie krytyki eurocentryzmu, jak i orientalizmu,

- należy dostrzec potrzebę wielopoziomowej refleksji, aprobaty i stosowania takich pojęć, jak na przykład glokalizacja, stąd badania globalnych stosunków powinny dokonywać się na wielu płaszczyznach oraz wypierać surowe, sztywne rozróżnienia mikro-makro, jak i inne upraszczające dualizmy,

- badania skutków globalizacji nie należy arbitralnie ograniczać do poszczególnych sfer życia, nadto należy je już postrzegać jako wszechobecną manifestację ${ }^{27}$.

Axford przychyla się do stwierdzenia Pieterse'a, że potrzeba globalnej wiedzy nieustannie wzrasta. Dodaje zarazem, że to, co konstytuuje wiedzę na temat tego, co globalne, jest jednocześnie kontestowane i zróżnicowane. Są to uwarunkowania, które można rozciągnąć na trzy „poziomy”, które wzięte razem stanowią wyraz wzrastającego zainteresowania, intelektualnej ciekawości nad naturą tego, co globalne, oraz tego, jak globalność badać:

Pierwszy poziom - stwierdza Axford - to rosnąca dostępność do danych dotyczących tego, co globalne. Niezwykle rozległa paleta informacji zebranych przez najróżniejsze podmioty: rządy, korporacje, organizacje międzynarodowe, społeczności naukowe, organizacje bezpieczeństwa, zebrane ze względu na najrozmaitsze potrzeby i cele. Drugi poziom łączy badania nad globalizacją, które na poziomie organizacyjnym są już bardzo mocno ugruntowane, czasami zaopatrzonych w ideologiczne lub/i normatywne agendy. Czym globalizacja jest i jak ją należy badać jest rządzone przez te dyscypliny, czasami z odzwierciedleniem normatywnego lub ideologicznego temperamentu dominujących w nich szkół myślenia. Trzeci poziom to domena studiów globalnych. Jednakże w tej sferze istnieje pewien problem, a mianowicie w istocie wiele programów mieniących się nazwą studiów globalnych powiela programy stosunków międzynarodowych, jednocześnie twierdząc, że oferują kuszące nowe spojrzenie niezwykle ambitnych naukowych badań ${ }^{28}$.

Pieterse podkreśla, że studia globalne domagają się nadal dużego intelektualnego zaangażowania, gdyż domagają się postawy przekraczania granic. Nie dziwi więc fakt, że idea krytycznych studiów globalnych wciąż znajduje się na wysokim poziomie ogól-

26 Tamże, s. 10.

27 B. Axford, The Multiple..., dz. cyt., s. 73-75.

28 Tamże, s. 74. 
ności. Tak też ostatecznie osądza Axford podjętą przez Pieterse'a próbę odpowiedzi na pytanie: What is global studies? W swoim artykule zaś podejmuje próbę przełamania tej ogólności. W jego przekonaniu

dobrym punktem wyjścia jest zaakceptowanie istnienia różnych/odmiennych globalnych narracji jako pewną normę, jako zwykłe fakty. Ale badacze muszą jednocześnie przyjąć, że globalna historia, globalne procesy i globalne wydarzenia nie odgrywają we wszystkich tych narracjach równej roli ${ }^{29}$.

Kolejnym istotnym elementem trzeciego programu badawczego jest kwestia transglobalności. Eliezer Ben-Rafael i Yitzhak Sternberg, autorzy pierwszego rozdziału (zatytułowanego With and beyond S.N. Eisenstadt: Transglobality) omawianej tu książki, starają się zmierzyć z pytaniem o to, czy transglobalność należy uznać tylko za nową fazę zwielokrotnionych nowoczesności, czy może raczej za nową erę przekraczającą epokę nowoczesności i postnowoczesności zarazem. Koncentrują się na najważniejszych uwarunkowaniach, które określają zmianę społeczną w społeczeństwach współczesnych w odniesieniu do: globalności, transnacjonalizmu, multikulturalizacji oraz decywilizacji (hybrydyzacji). Jak zauważają Preyer i Sussman we Wprowadzeniu, są to obecnie jedne z najważniejszych wymiarów, które powodują zmiany i sprzeczności w społecznej komunikacji ${ }^{30}$. Ich wpływy generowane są przez sprzeczne siły i prowadzą do nowych sytuacji i nowych zjawisk. Stąd rodzi się pytanie, czy reprezentują one tylko zmianę ilościową, czyli nowy stopień czegoś, co znane było już w przeszłości, czy może chodzi o zmianę jakościową, to znaczy prowadzą one ku nowym horyzontom ${ }^{31}$.

Aby zmierzyć się z tą kwestią, autorzy proponują pojęcie transglobalności, które ma być kombinacją pojęć globalności i transnacjonalizmu (transnazionality) jako wyrażających dwie główne siły wpływające na dynamikę i transformację współczesnego społecznego świata. Jak piszą: „Proponujemy zdefiniowanie pojęcia transglobalności jako obejmujące dwa główne aspekty współczesnej rzeczywistości społecznej: globalności i transnacjonalizmu"32. Autorzy explicite stwierdzają, że pojęcie transglobalności było ukute wcześniej, a ich badania wpisują się w szerszy kontekst. Tym niemniej ich ambicją jest wyznaczyć nową drogę konceptualną i teoretyczną, która przekroczy między innymi dyskurs postmodernistyczny, zarówno w wydaniu Habermasa, jak i Foucaulta. Ci ostatni wiele mówili o postnowoczesności jako kolejnym etapie nowoczesności. Natomiast zdaniem Ben-Rafaela i Sternberga te dwa główne czynniki zmiany: globalność i transnacjonalizm spowodowały, że należy już postawić pytanie, co po nowoczesności, czyli wyjść ponad dyskurs nowoczesność/zwielokrotnione nowoczesności. Chodzi o tropienie konfiguracji, które mogą zwiastować nową erę, na przykład transglobalną, nie zaś tylko wskazywać na nowe etapy epoki nowoczesnej czy na jakiś koniec historii ${ }^{33}$.

\footnotetext{
29 Tamże, s. 76-77.

${ }^{30}$ G. Preyer, M. Sussman (red.), dz. cyt., s. 16.

31 Por. E. Ben-Rafael, Y. Sternberg, dz. cyt., s. 46.

32 Tamże s. 47.

33 Tamże s. 46-47.
} 
Omawiany rozdział dostarcza nam także obszernych wyjaśnień i ocen co do wskazanych kluczowych dla współczesności procesów i pojęć. Warto odnieść się przynajmniej do niektórych.

Izraelscy socjologowie Ben-Rafael i Sternberg zauważają, że transnacjonalizacja ${ }^{34}$ oraz globalizacja wpływają przede wszystkim na brak spójności i jednorodności kulturowej społeczeństw. Ponadto przemożnie wpływają na multikulturalizację społeczeństw, to jest na instytucjonalizację społeczno-kulturowego pluralizmu jako permanentnego i normalizującego się już aspektu społecznego porządku. To, że zjawisko to nabrało takiego znaczenia, wynika między innymi stąd, że te napływowe wspólnoty przybyły do społeczeństw, gdzie na demokrację zaczęły silnie oddziaływać dodatkowe siły endemiczne, to znaczy, że nastąpił czas, kiedy między innymi wpływ sektora lokalnego na polityczną partycypację uległ znacznej intensyfikacji ${ }^{35}$.

Pierwszym pojęciem, które autorom tym wydaje się właściwe do wyrażenia kierunku rozwoju przekraczającego nowoczesność/zwielokrotnione nowoczesności, jest pojęcie globalności. Globalność to w istocie efekt globalizacji. Globalność wyraża się w ogromnym wzajemnym powiązaniu między aktorami z całego globu, czemu towarzyszy ich samoświadomość. Zjawisko to jest bowiem bezpośrednim rezultatem wzrastającego przepływu idei, technologii, zwyczajów, środków przekazu i samych ludzi, jakże ułatwionym obecnie dzięki masowym środkom transportu i komunikacji. Globalność wyraża się także w tym, że przekraczanie granic (cross-cutting boundaries) stało się normą. Przeciwieństwem globalności jest lokalność, a dualność ta może rodzić napięcia między tym, co zewnętrzne i wewnętrzne ${ }^{36}$.

Pojęcie transnacjonalizmu w omawianym tekście nie pozostaje bez ścisłych związków z pojęciem globalności. Stanowi również nowe zjawisko, które nie zostało jeszcze wystarczająco wyraźnie uchwycone w ramach koncepcji zwielokrotnionych nowoczesności. Fenomen ten w istocie daje wyraz wielu głównym sprzecznym i transformacyjnym aspektom aktualnych społeczeństw. Transnacjonalizm jest obecnie skutkiem ogromnej migracji ludności, zwłaszcza na Zachód z pozostałych części świata, jak i tworzenia się nowych państw oraz granic po upadku multinarodowych i multietnicznych państw, takich jak Związek Radziecki czy była Jugosławia. Jest on także motywowany i ułatwiany przez coraz to nowsze technologie w transporcie i komunikacji. Dla współczesnych migrantów migracja nie oznacza już całkowitego zerwania z domem, przyjęcia nowej kultury ze szkodą dla rodzimej, nie oznacza również całkowitej zmiany zachowań. Dzisiejsi migranci są przykładem tego, co naukowcy opisują jako transnarodowe wspólnoty lub diaspory ${ }^{37}$.

Transnarodowe diaspory (transnational diasporas) składają się z rozproszonych wspólnot, dzielących takie cechy, jak pochodzenie, tożsamość religijna czy religijne dziedzictwo.

${ }^{34}$ Na temat transnacjonalizmu Eliezer Ben-Rafael i Yitzhak Sternberg (pod redakcją i we współpracy z Judit Bokser Liwerant i Yosefem Gornym) w 2009 roku opublikowali bardzo obszerną, 700-stronicową pracę zbiorową pt. Transnationalism. Diasporas and the advent of a new (dis)order, Brill, Leiden-Boston 2009 (vol. 9 „International Comparative Social Studies”).

35 E. Ben-Rafael, Y. Sternberg, dz. cyt., s. 42.

36 Tamże s. 39-40.

37 Tamże, s. 40. 
Podzielają też nowe formy międzywspólnotowych wzajemnych powiązań, w tym w pełni diasporyczne urządzenia instytucjonalne, wyrażające je jako podmioty transnarodowe. Transnacjonalizm jest zjawiskiem związanym w tym kontekście również z tak zwaną akulturacją i niepełną asymilacją. Akulturacja to proces polegający na gwałtownym przeobrażaniu jednej kultury pod wpływem innej kultury. I znowu można powiedzieć, że zmiana społeczna, której rezultatem w tym przypadku jest transnacjonalizm, jest efektem głębokiego różnicowania się w obrębie współczesnych społeczeństw ${ }^{38}$. Transnacjonalizacja wiąże się ostatecznie z procesem wzrostu osłabiania i relatywizacji władzy i spójności państw narodowych, które obecnie są znacznie mniej zdolne kontrolować i wpływać na sieci oraz przepływ zasobów przekraczających granice państwowe ${ }^{39}$.

\section{Zakończenie}

Niniejszy tekst nie stanowił w zamierzeniu prostej recenzji. Nie jest też autorskim artykułem naukowym, który per definitionem musi nosić znamiona oryginalności. Jest on zaś artykułem przeglądowym, którego celem było przybliżenie polskiemu czytelnikowi, choćby w niewielkim stopniu, bogactwa intelektualnego, jakie charakteryzuje spuściznę Shmuela N. Eisenstadta. Varieties of multiple modernities uznaję za ważny wkład w dorobek badań nad myślą izraelskiego socjologa. Głównym argumentem na rzecz takiej tezy jest to, że autorzy Varieties wskazują wprost na szereg przesłanek dowodzących niezwykłej aktualności myśli Eisenstadta. To z kolei pokrywa się także z moim przekonaniem co do tego intelektualisty, socjologa, politologa i filozofa. Jednocześnie autorzy, zarówno ci przeze mnie referowani, jak i pozostali, podjęli próbę stawienia czoła najbardziej aktualnym zagadnieniom i wydarzeniom otaczającego nas świata. I w tym względzie uważam, że autorzy dowiedli, iż myśl Eisenstadta jest bardzo dobrym do tego zadania narzędziem interpretacyjnym.

Sądzę, że książka ta, również jako rezultat projektu interdyscyplinarnego, stanowi ogromne źródło wiedzy nie tylko z myśli Eisenstadta, ale też z dyscyplin najróżniejszych: od epistemologii po antropologię prawa. Jest zarazem dziełem trudnym - w tym sensie, że pisanym na wysokim poziomie naukowym, a więc wymagającym dużej uważności w trakcie lektury. Zapewne jednak jako zbiór refleksji nad olbrzymim bogactwem wątków może być inspiracją dla reprezentantów różnych dyscyplin: z zakresu nauk o społeczeństwie i o polityce oraz z filozofii.

Dla mnie szczególnie istotne i inspirujące były analizy z zakresu studiów globalnych. Chyba mogę stwierdzić, że jest to dziedzina, która stanowi jedną z kluczowych perspektyw i punktów odniesienia prezentowanej książki. Głównie dlatego, że traktowana jest przez autorów jako fundament trzeciego (przyszłego) programu badawczego nad myślą Eisenstadta. I w tym względzie uważam, że ich wybór jest słuszny. Procesy globalizacyjne na różne sposoby i w różnych zakresach doprowadziły do zjawisk, które już mają swoją

38 Tamże, s. 41.

39 Tamże, s. 42. 
własną nazwę, a mianowicie do globalności (globals). Ukuto już także nazwę dla badań nad globalnościami w postaci zagadnień globalnych (global issues). Studia globalne bez wątpienia są jednym z ważniejszych wyzwań dla współczesnej nauki. Chociaż kilka lat temu mówiło się, że stanowią one zasadniczo interdyscyplinarny, a także transdyscyplinarny projekt naukowy, obecnie panuje tendencja do traktowania ich jako w pełni odrębnej dyscypliny badawczej. Zagadnienia globalne muszą więc znajdować się w gestii badaczy różnych dyscyplin, zjawisko globalności ma bowiem charakter bardzo złożony i wielowymiarowy, dlatego też domaga się rozpoznania z różnych perspektyw badawczych. To czyni, bez wątpienia w sposób ciekawy, przedstawione tu dzieło.

Książka ta oczywiście nie jest pozbawiona pewnych defektów. Mimo że pisana była przez wytrawnych badaczy, to nierzadko odnosi się wrażenie, że podejmowane tematy są jakby niedokończone, niewystarczająco przemyślane i przeanalizowane. Łatwo jednak podać argument łagodzący ten zarzut. Otóż podnoszone problemy są na tyle skomplikowane, a zarazem na tyle aktualne, że chyba trudno oczekiwać od autorów, by prezentowali w pełni gotowe na nie recepty. Oznacza to ponadto, że lektura Varieties może być inspiracją do nowych badań nad myślą Eisenstadta, a zakres trzeciego programu badawczego może się znacznie rozszerzyć. Takie zamierzenie przyświeca także autorowi niniejszego tekstu.

\section{Bibliografia}

Axford B., The Multiple Modernities Debates as a Prospectus for Global Scholarship: More Opportunities Than Dead-Ends?, [w:] G. Preyer, M. Sussman (red.), Varieties of Multiple Modernities. New Research Design, „International Comparative Social Studies” 2016, No. 33.

Ben-Rafael E., Sternberg Y., Bokser Liwerant J., Gorny Y. (red.), Transnationalism. Diasporas and the advent of a new (dis)order, Brill, Leiden-Boston 2009.

Ben-Rafael E., Sternberg Y., With and beyond S.N. Eisenstadt: Transglobality, [w:] G. Preyer, M. Sussman (red.), Varieties of Multiple Modernities. New Research Design, „International Comparative Social Studies" 2016, No. 33.

Eisenstadt Sh.N. (red.), Readings in Social Evolution and Development, Pergamon Press, Oxford 1970.

Eisenstadt Sh.N., Epoka osiowa w dziejach ludzkości, [w:] H. Joas, K. Wiegandt (red.), Kulturowe wartości Europy, Wydawnictwo IFiS PAN, Warszawa 2012.

Eisenstadt Sh.N., Program of A Sociological Approach to Comparative Civilizations: The Development and Direction of a Research Program 1986, [w:] tegoż, Multiple Modernities A Paradigm of Cultural and Societal Evolution, „Proto Sociology. An International Journal and Interdisciplinary Research" 2007, Vol. 24.

Eisenstadt Sh.N., Utopia i nowoczesność. Porównawcza analiza cywilizacji, Oficyna Naukowa, Warszawa 2009.

Fligel A., Różnorodność w jedności? Krótki esej o Europie w świetle teorii zwielokrotnionych modernizacji Shmuela N. Eisenstadta, „Cywilizacja i Polityka” 2016, nr 15.

Joas H., Wiegandt K. (red.), Kulturowe wartości Europy, Wydawnictwo IFiS PAN, Warszawa 2012. 
Marangudakis M., Multiple Modernities and the Theory of Indeterminacy: On the Development and Theoretical Foundations of the Historical Sociology of Shmuel N. Eisenstadt, [w:] G. Preyer, M. Sussman (red.), Varieties of Multiple Modernities. New Research Design, „International Comparative Social Studies” 2016, No. 33.

Pieterse J.N., Multipolarity Means Thinking Plural: Modernities, [w:] G. Preyer, M. Sussman (red.), Varieties of Multiple Modernities. New Research Design, „International Comparative Social Studies" 2016, No. 33.

Pieterse J.N., What is global studies?, „Glabalizations” 2013, Vol. 10, 4, https://nebula.wsimg. com/7728311b84f589fe8497af3191493ee6?AccessKeyId=FF8C6D6A9193E63EE295\&disp osition=0\&alloworigin=1 [dostęp: 14.01.2020].

Preyer G., Globalization and the Third Research Program of Multiple Modernities, https:// www.academia.edu/28292144/Gerhard Preyer_Globalization and the Third Research Program of Multiple Modernities [dostęp: 14.01.2020].

Preyer G., Sussman M. (red.), Varieties of Multiple Modernities. New Research Design, „International Comparative Social Studies" 2016, No 33.

Preyer G., Zur Aktualität von Shmuel N. Eisenstadt. Eine Einleitung in sein Werk, Springer VS, Wiesbaden 2011.

\section{Streszczenie \\ Shmuel N. Eisenstadt w nowej odsłonie. Wokół książki Varieties of Multiple Modernities. New Research Design}

Badania nad myślą Shmuela N. Eisenstadta (1923-2010), jak i te kontynuujące i rozwijające jego dziedzictwo, w tym adaptujące na szeroką skalę stworzoną przez niego teorię i metodologię nieustannie przybierają na sile i to w najrozmaitszych zakątkach świata. Fakt ten nie może dziwić, skoro rezultaty jego własnych obszernych badań, prowadzonych intensywnie przez ponad pięćdziesiąt lat, uznawane są zazwyczaj za jeden z najważniejszych i najoryginalniejszych produktów w dziedzinie socjologii, jak również filozofii cywilizacji, filozofii kultury, filozofii polityki i społeczeństwa drugiej połowy XX i początku XXI wieku. Wskazane przesłanki skłoniły mnie do napisania niniejszego tekstu, który z założenia ma być artykułem przeglądowym, tj. krytyczną prezentacją kilku istotnych wątków jednej z nowszych książek pisanych z perspektywy teorii Eisenstadta, zatytułowanej Varieties of multiple modernities. New Research Design. Książka ta stanowi krytyczną i analityczną kontynuację teorii Eisenstadta. Jest to bardzo ważny wkład w dorobek badań nad myślą Eisenstadta, zarazem znacznie przekraczający jego dziedzictwo. Autorzy, zarówno ci przeze mnie referowani, jak i pozostali, podjęli próbę stawienia czoła najbardziej aktualnym zagadnieniom i wydarzeniom otaczającego nas świata. To, czy narzędzia, jakich dostarcza Eisenstadt, pomagają w tego typu przedsięwzięciach, pozostawiam opinii czytelnika Varieties of multiple modernities. Książka, jako wynik projektu interdyscyplinarnego, stanowi bogate źródło wiedzy i może być inspiracją dla reprezentantów różnych dyscyplin.

Słowa kluczowe: Shmuel N. Eisenstadt, Gerhard Prayer, zwielokrotnione nowoczesności, studia globalne, koncepcja niedookreślenia, transglobalność, transnacjonalizm 


\section{Summary}

Shmuel N. Eisenstadt in a new setting. Varieties of Multiple Modernities. New Research Design

Research on the thought of Shmuel N. Eisenstadt (1923-2010), as well as studies continuing and developing his ideas, is gaining traction in different corners of the world. This fact is not surprising since the results of his own extensive research are usually considered as one of the most important and original products in the field of sociology, philosophy of civilisation, philosophy of culture, as well as the philosophy of politics and society of the mid- $20^{\text {th }}$ and early $21^{\text {st }}$ century. This article offers a critical presentation of several important threads of a recent book entitled Varieties of multiple modernities: New Research Design (hereinafter: Varieties) that engages with the theories of Shmuel N. Eisenstadt.

This book is a very important contribution to work on the thought of the Israeli sociologist and it moves beyond his ideas. The authors make an attempt to face current issues and events in the world around us. Whether or not the tools provided by Eisenstadt help in this type of endeavour, I leave the readers of Varieties to judge. The book, a result of an interdisciplinary project, is a huge source of knowledge. It can be an inspiration for representatives of various disciplines.

Keywords: Shmuel N. Eisenstadt, Prayer G., multiple modernities, global studies, theory of indeterminacy, transglobality, transnationalism 
Waldemar Mańkowski

wm.lodz@gmail.com

Badacz niezależny

\section{Polityka gospodarcza jako działanie państwa na tle globalnych zmian}

\section{Wstęp}

Na przełomie XX i XXI wieku ludzkość stanęła w obliczu globalnych zmian, przy których wszystkie dotychczas przeżyte rewolucje oraz sekularne fale niestabilności społeczno-politycznej mogą zmienić się w zaledwie nieznaczące incydenty. Poza zmianami świata społecznego, gospodarczego i politycznego podstawową determinantą biologicznego przetrwania ludzkości stają się, w pierwszych dekadach XXI wieku, transfiguracje geografii fizycznej Ziemi. Dynamika klimatu, topniejąca pokrywa lodowa, zanieczyszczenia lądów i oceanów oraz dynamiczne wymieranie gatunków to podstawowe efekty obecnej epoki, zwanej antropocenem.

W wymiarze politycznym zniknął ład światowy ukształtowany przez zimną wojnę. Dwubiegunowy porządek dobiegł końca na fali globalizacji, którą początkowo uznano za pożyteczny trend, a która obecnie wzbudza strach. Kryzysy finansowe obnażyły słabość kapitalizmu w jego neoliberalnej wersji. Dotychczasowe poglądy, że liberalna demokracja jest i pozostanie niezmiennym elementem ludzkiej kultury sprowokowała siły pozostające do niej w opozycji do przejmowania kontroli w miejscach, gdzie to możliwe. Powszechną bolączką społeczną są narastające gigantyczne nierówności. Kultura marketingu politycznego pozwala na stosunkowo łatwe manipulowanie masami ludzkimi. W wielu wypadkach wszystkie polityczne hamulce wymuszające zachowania zapewniające przestrzeganie dotychczasowych norm życia społecznego oraz polityki międzynarodowej przestają działać. Kreuje to polityczną i społeczną niestabilność, w konsekwencji stwarzając zagrożenia. Wśród zmian obalających stary porządek świata dynamicznie rozwijająca się gospodarka zarówno generuje zagrożenia, jak i stwarza nadzieje na przyszłość. 
W oczekiwaniu na nowy porządek państwo, jako najważniejsza organizacja społeczna, usiłuje nadawać kierunek zmianom. Celem artykułu jest przedstawienie polityki gospodarczej jako narzędzia interwencji państwa w ekonomiczną sferę życia społeczeństw. Wstępnym założeniem jest teza, że polityka ta ewoluuje wraz ze zmieniającym się otoczeniem gospodarki - jest więc obiektem permanentnego udoskonalania. Pytaniem badawczym jest zagadnienie, czy opisywane narzędzie - działanie państwa - jest na tyle mocne, żeby mogło być skuteczne. Przez taką skuteczność należy rozumieć, po pierwsze, możliwość realizacji założonych celów oraz, po drugie, możliwość takiego sformułowania celów, aby osiągnąć realny wpływ na życie gospodarcze i w konsekwencji także na inne sfery działania człowieka. Ostatecznym celem działania państwa w dziedzinie gospodarki winno być stwarzanie takich warunków, by ludzie byli w stanie dostosować się do zmieniającego się świata oraz byli w stanie osiągnąc i zachować dobrostan (istotna uwaga: wobec globalnej presji demograficznej, skorelowanej z coraz mniejszą dostępnością zasobów nie chodzi już o powszechny dobrobyt, lecz właśnie o dobrostan). Metodą analizy, jaką zastosowano w artykule, jest autorska analiza literatury przedmiotu. Ukierunkowano ją na ukazanie podstaw, jak również zmienności w czasie polityk gospodarczych państwa.

\section{Globalna zmiana - kreacja nowego świata}

Punktem wyjścia do rozważań o współczesnym świecie gospodarczym jest prawo ludności Thomasa Malthusa. Malthus, anglikański pastor i badacz problemów społecznych, opublikował w 1798 roku pracę An Essay on the Principle of Population. W pracy tej sformułował wniosek, że „klęska głodu [...] utrzymuje w równowadze liczbę ludności z liczbą żywności na świecie”. Stwierdził, że wzrost produkcji żywności zawsze doprowadzi do wzrostu liczby ludności. Pojawi się wtedy nowa siła robocza, a z czasem zarobki wskutek działania prawa podaży-popytu wrócą do poziomu biologicznego przetrwania. Stały wzrost poziomu życia jest więc niemożliwy. Postęp technologiczny czy niespodziewany dar natury - urodzaj lub brak niszczących klęsk, takich jak zarazy, może przynieść tylko wzrost demograficzny, a wzrost standardów życiowych, jeśli nastąpi, może być wyłącznie krótkotrwały². Sytuację taką określono jako pułapkę maltuzjańską. Pułapka ta towarzyszyła gospodarce społeczeństw od tysiącleci. Zgodnie z jej regułami działały zarówno słabo rozwinięte społeczeństwa peryferyjne, jak i cywilizacyjne centra, w tym na przykład rozwinięty ekonomicznie i organizacyjnie starożytny Rzym.

Reguły Malthusa przestały obowiązywać w jednym miejscu na Ziemi - w Anglii, prawdopodobnie około $1640 \mathrm{roku}^{3}$. Przezwyciężenie pułapki było procesem nieśpiesznym i długotrwałym. Wzrost dochodów ludności był początkowo powolny, ale systematyczny. Tempo wzrostu przyśpieszało od rewolucji przemysłowej w Anglii, poprzez rozwój

\footnotetext{
1 T.R. Malthus, Prawo ludności, Jirafa Roja, Warszawa 2007, s. 50.

2 Malthus pisał też o konieczności istnienia nierówności społecznych i o fatalnych jego zdaniem następstwach sytuacji, gdyby każdy miał pełne prawo do równej części produkcji ziemi. Tamże, s. 63, 64 .

${ }^{3}$ A. Leszczyński, Skok w nowoczesność. Polityka wzrostu w krajach peryferyjnych 1943-1980, Wydawnictwo Krytyki Politycznej, Warszawa 2013, s. 54.
} 
ekonomiczny wielkich obszarów, kryzysy polityczne (wojny światowe) i ekonomiczne (w tym największy kryzys kapitalizmu w latach 1929-1933). Zmiany były coraz szybsze - gospodarka rosła, następował rozwój społeczny i wzrost demograficzny. Rozszerzała się skala ingerencji w środowisko przyrodnicze. Przyroda, która wcześniej utrzymywała populację w stanie równowagi liczebnej, sama stała się przedmiotem działań i stopniowo uległa zmianom, które upoważniają do nazwania obecnej epoki geologicznej antropocenem $^{4}$. Końcowym efektem tych procesów stało się uformowanie dzisiejszego globalnego i dynamicznie zmieniającego się świata. W pierwszym dwudziestoleciu XXI wieku oczywiste stało się załamanie dotychczasowego porządku świata. Wizje przyszłości są, jak zawsze, obciążone wysokim stopniem niepewności. Niepewność ta jest immanentną cechą każdej prognozy. Jednak niepewność co do skutków obecnej zmiany jest dodatkowo wzmocniona tempem i nieprzewidywalnością skutków.

Początek obecnego etapu zmian można datować na moment zakończenia zimnej wojny. Skutki dotyczą wszystkich sfer życia. Pojawiła się wielobiegunowość, przede wszystkim polityczna, gospodarcza i militarna. Sieciowe społeczeństwo zaczęło funkcjonować zupełnie inaczej niż przed pojawieniem się internetu. Zmiany nastąpiły nie tylko w warstwie społecznej, wykreowały się również przekształcenia na poziomie osobniczym. Rodzące się pokolenia, otoczone siecią i sztuczną inteligencją, zmieniają sposób myślenia i postrzegania świata. Jak pisze badacz sieci: ,„pełen polotu umysł renesansu, racjonalny umysł oświecenia, nowatorski umysł rewolucji przemysłowej wkrótce może należeć do przeszłości"5. Zanika w świecie sieciowym zjawisko prywatności. Przepływy finansowe i informacyjne rozchodzą się z prędkością promieniowania elektromagnetycznego, co zmienia architekturę globalnej gospodarki. Pojawiają się w skali globalnej nowe bądź występujące dotychczas jako endemiczne choroby kreujące problemy społeczne. Dewastacja środowiska połączona ze wzrostem demograficznym oraz ze zmianami klimatycznymi tworzy zagrożenia. Skutki tych zjawisk są jeszcze dziś nierozpoznane. Nowe zjawiska pogodowe - według umiarkowanych prognoz - sprowadzą zasadnicze zmiany schematów pogodowych, które nie muszą przynieść końca świata ${ }^{6}$, jednak niewątpliwie oznaczać będą problemy dla miliardów ludzi. Tym samym podważą każdy aspekt dotychczasowej organizacji społeczeństwa ${ }^{7}$.

Suma zmian w niedalekiej już przyszłości przekonstruuje społeczeństwa, politykę i gospodarki. Zrodzi się nowy świat i wyłoni się inne społeczeństwo. Tak więc początek XXI wieku jest momentem powstawania nowego, oczekiwanego porządku. Charakteryzująca się turbulencjami i dynamicznymi, lawinowymi przełomami współczesność to czas interregnum.

${ }^{4}$ Takiego określenia użył Paul J. Crutzen - laureat Nagrody Nobla z dziedziny chemii w 1995 roku. E. Bińczyk, Epoka człowieka. Retoryka i marazm antropocenu, PWN, Warszawa 2018, s. 11.

5 N. Carr, Plytki umyst. Jak internet wptywa na nasz mózg, Wydawnictwo Helion, Gliwice 2013, s. 21.

${ }^{6}$ Inne, katastroficzne prognozy mówią, że w przypadku skrajnej bezradności rodzaju ludzkiego zmiany klimatu mogą doprowadzić do zniszczenia gatunku ludzkiego.

${ }^{7}$ M. Maslin, Zmiany klimatu, Wydawnictwo Uniwersytetu Łódzkiego, Łódź 2018, s. 11-13. 


\section{Życie gospodarcze na tle zmian z przełomu wieków}

Życie gospodarcze składa się z niepoliczalnych wektorów działań, podążających w różnych, często przeciwstawnych kierunkach - jego immanentną cechą są gry o sumie zerowej. Dodatkowo gry rynkowe charakteryzują się różną dynamiką w różnych obszarach. Przykładem służy, po pierwsze, rozwój technologiczny postępujący w tempie lawinowym, którego efekty są błyskawicznie wykorzystywane przez rynek. Po drugie, reakcje na dewastację środowiska przyrodniczego następują powoli i nie dotrzymują kroku szybkości dewastacji planety ${ }^{8}$. W takich okolicznościach państwo jako największy system społeczny ${ }^{9}$ próbuje regulować gospodarkę poprzez działania zwane polityką gospodarczą.

Poniżej zostanie przedstawiona polityka gospodarcza jako jedno z podstawowych zadań państwa. Polityka gospodarcza jest działaniem o ogólnospołecznym zasięgu, istotnie wpływającym na życie wszystkich członków społeczeństwa. Na tle ogólnego opisu zjawiska, który przedstawia źródła, podstawowe obszary i instytucje oraz ewolucję w reakcji na zachodzące zmiany, zobrazowany zostanie jeden z modeli polityki gospodarczej - europejski model społecznej gospodarki rynkowej. Należy przy tym zaznaczyć, że polityka gospodarcza jest w dużej części ripostą na zmiany, które już zaszły. Jej próby wyprzedzania wydarzeń są obarczone przywołanym wyżej zjawiskiem niepewności. Dlatego też odpowiedź polityki gospodarczej na zachodzące zjawiska może niekiedy wydawać się spóźniona.

\section{Polityka gospodarcza jako przykład polityki o ogólnospołecznym zasięgu}

Gospodarka jest strukturą o niezwykłym stopniu komplikacji, trudną tym samym do objaśnienia. Jak napisał już w połowie XX wieku Galbraith: „Pierwszym warunkiem zrozumienia współczesnego życia gospodarczego i społecznego jest jasny pogląd na zależność między wydarzeniami a pojęciami, które je thumaczą. [...] Gospodarka, tak jak inne przejawy życia społecznego, nie przystaje do prostego spoistego wzorca. Wręcz przeciwnie, często wydaje się bezładna, prymitywna i nielogiczna. Ale człowiekowi potrzebne jest wyjaśnienie"10.

\footnotetext{
8 Jest to związane z rabunkową eksploatacją środowiska, z której korzystają podmioty (gospodarcze, ale i polityczne) decydujące o całokształcie gospodarki. Przerzucają one w sposób bezwzględny tzw. koszty zewnętrzne (w tym wypadku koszty dewastacji środowiska) na ogół ludności. Ich partykularne interesy skłaniają do opóźniania i spowalniania reakcji na problemy związane ze środowiskiem przyrodniczym i brania odpowiedzialności za koszty zewnętrzne. W dominującej logice biznesu powszechne jest działanie w kategoriach gry, która toczy się o to, by wziąć jak najwięcej.

9 Państwo jest największym, w sensie jakościowym, systemem społecznym. Wprawdzie geograficzne wymiary lokują na czele organizacje ponadnarodowe, a zasoby kapitałowe i obroty największych korporacji są większe niż w gospodarkach niektórych państw, jednakże zasięg kompetencji państwo ma największy ze wszystkich systemów/organizacji społecznych.

10 J.K. Galbraith, Społeczeństwo dobrobytu. Państwo przemysłowe, PIW, Warszawa 1973, s. 25.
} 
W obliczu ogromnego stopnia komplikacji zjawisk gospodarczych nauki ekonomiczne dla objaśnienia dążeń i sposobu funkcjonowania społeczeństwa w sferze gospodarczej (a więc dla sprecyzowania celów polityki gospodarczej) - dopuszczają możliwość posługiwania się metaforami. Ułatwiają one zrozumienie skomplikowanych zjawisk w sytuacji, kiedy próby naukowego wyjaśnienia współczesnych procesów gospodarczych opisują świat pozornie nieobjaśnialny. Założeniem jest to, że biegłość w objaśnianiu i zrozumieniu procesów gospodarczych jest procesem intuicyjnym i wymagającym doświadczenia. Zgodnie z tą ideą metafory mają ułatwić rozumienie rzeczywistości. Tak więc sposoby wyjaśnienia fundamentalnych zjawisk ekonomicznych mogą przedstawić gospodarkę jako:

- mechanizm,

- system,

- dramat ${ }^{11}$.

Metafora mechanizmu nawiązuje wprost do systemu newtonowskiego, czyli opisu świata językiem matematyki. Matematyka i teoria gier są opisem praw życia społecznego, w tym gospodarczego. Metafora mechanizmu u podstaw sięga do teorii Leona Walrasa i jego analiz dotyczących mechanizmu równowagi jako pochodnej systemu cen, tak klarownego, że można je porównać do urządzenia (tzw. prawo Walrasa) ${ }^{12}$.

Metafora systemowa sięga do opisu systemów gospodarczych i do metodologii analiz systemowych. W tym ujęciu uznanie zdobyło podejście kontekstualne, wychodzące z założenia, że zjawiska, takie jak geografia, klimat, etniczność, język, kultura, ideologia, religia i technika wywierają wpływ na politykę, ale polityka nie wywiera na nie żadnego wpływu. Koncepcje takie zdominowały rozwój ekonomii neoklasycznej, a indywidualizm metodologiczny stanowił tu podstawę konstruowania teorii. Przedstawiciele kontekstualizmu uważają, że rezultaty systemowe są wynikiem interakcji między jednostkami działającymi spójnie z punktu widzenia zasad indywidualnego interesu.

W przeciwieństwie do poprzednich stanowisk, które eksponują determinizm w działaniach gospodarczych, metafora dramatu nawiązuje do chaosu i probabilizmu w działaniach człowieka (w ogólności, w tym działań gospodarczych). Nowe nurty ekonomii, w tym idee behawioralne, zaprzeczyły istnieniu homo oeconomicus. Jednocześnie wystąpiły niezauważane dotąd zjawiska, z których wyłania się obraz gospodarki jako dramatu. Zjawiska potęgujące zniewolenie, bezradność i zagubienie. Można tu przywołać przykład tzw. gospodarki kasyna (hegemonia finansów jako gry), narastających w skali dotychczas niewyobrażalnej nierówności oraz kosztów zewnętrznych działalności potęg ekonomicznych - niszczenie środowiska przyrodniczego czy generowanie zmian klimatu.

Powyższy krótki wstęp pozwala na zobrazowanie, jak skomplikowanym światem jest system gospodarczy i jak ważna, ale i złożona jest rola działań społecznych nazywanych polityką gospodarczą.

Polityka gospodarcza jest jedną z najważniejszych dziedzin polityki publicznej. Polega na programowaniu i prowadzeniu działań zmierzających do osiągnięcia dwóch celów, to

11 J. Wilkin, Instytucjonalne i kulturowe podstawy gospodarowania, Wydawnictwo Naukowe Scholar, Warszawa 2016, s. 38-52.

12 M. Blaug, Teoria ekonomii. Ujęcie retrospektywne, PWN, Warszawa 2000, s. 585. 
jest możliwie szybkiego tempa rozwoju gospodarczego oraz równowagi - stabilności makroekonomicznej w powiązaniu z osiąganiem innych społecznych celów rozwojowych ${ }^{13}$. Polityka gospodarcza i jej składowe klasyfikowane są z różnych punktów widzenia. Jako polityka podmiotowa dzieli się na rządową i komunalną (samorządową). Funkcjonalnie dzieli się na polityczno-gospodarcze podsystemy sektorowe, między innymi finansowy, budowlany, rolny i transportowy. Obszarowo obejmuje zasięg centralny i lokalny (regionalny) ${ }^{14}$.

Przedmiotem polityki gospodarczej jest gospodarka kraju, a więc przedsiębiorstwa prywatne i publiczne oraz gospodarstwa domowe, instytucje rynkowe i system prawa gospodarczego. Na osobne potraktowanie wśród przedsiębiorstw zasługują banki. Poświęca się im szczególną uwagę ze względu na hegemonię finansów ${ }^{15} \mathrm{~W}$ obrocie gospodarczym, wobec czego banki wymagają na przykład osobnego systemu nadzoru.

Podmiotem polityki gospodarczej są władze publiczne (rządowe i samorządowe), wyposażone w kompetencje decyzyjne przez władzę prawodawczą - parlament. Sferą działania jest natomiast głównie polityka makroekonomiczna, której elementami są polityka fiskalna i budżetowa, polityka pieniężna (w tym polityka kursowa) oraz polityka nadzoru ostrożnościowego nad sektorem finansowym (bankowym). Należy stwierdzić również, że rezultatem działań w skali makro jest wymuszanie określonych zachowań podmiotów mikroekonomicznych. Przytoczyć tu można reakcje przedsiębiorstw na rozwiązania z zakresu systemu podatkowego czy też działania podmiotów fizycznych w związku z polityką płacową. Na płaszczyznach podstawowych rozgrywają się wszystkie działania podsystemów gospodarczo-politycznych. Przykładem są polityki sektorowe.

\section{Niesprawności rynku jako źródło polityki gospodarczej}

W klasycznej pracy Adama Smitha Badania nad natura i przyczynami bogactwa narodów $^{16}$, czyli u samych podstaw współczesnej ekonomii jako nauki, jednoznacznie znajdują się odniesienia do rynku, konkurencji i alokacji zasobów jako bazy wzrostu i rozwoju gospodarczego. Smith zakłada, że efektywność gospodarcza osiągana jest przy braku zawodności rynku, to jest w warunkach konkurencji doskonałej (co jest rodzajem modelu idealnego). Indywidualne decyzje podmiotów gospodarujących, podejmowane we własnym interesie, prowadzą przy spełnieniu tego założenia do efektywności. Efektywność tę współcześnie określa się jako optimum w rozumieniu Pareta ${ }^{17}$. Główne nurty

13 D.K. Rosati, Polityka gospodarcza. Wybrane zagadnienia, Wydawnictwo SGH, Warszawa 2017, s. 15.

14 M. Żmigrodzki (red. nauk.), Encyklopedia politologii, t. 1., Kantor Wydawniczy Zakamycze, Kraków 1999, s. 233.

15 Chodzi tu o udział finansów w kreowaniu dochodów, który przewyższył już dochody produkowane przez sferę rzeczową. Istotny jest także sposób gospodarowania, który nie opiera się na tradycyjnych kalkulacjach, a jest wynikiem gier spekulacyjnych (co niekiedy określa się krugmanowskim terminem gospodarka kasyna).

${ }^{16}$ A. Smith, Badania nad natura i przyczynami bogactwa narodów, PWN, Warszawa 2007.

17 Vilfredo Pareto - ekonomista włoski, najsławniejszy przedstawiciel tzw. szkoły lozańskiej (matematycznej); opracował teorię wyborów; podkreślał, że ekonomia jest strukturalnie powiązana z socjologią i polityką gospodarczą. W. Stankiewicz, Historia myśli ekonomicznej, PWE, Warszawa 2000, s. 257-258. 
ekonomii akceptują kryterium optimum (efektywności) Pareta mówiące (w skrócie), że efektywne są takie rodzaje alokacji zasobów, po osiągnięciu których niczyjej sytuacji nie da się poprawić bez jednoczesnego pogorszenia sytuacji kogoś innego ${ }^{18}$. Innymi słowy, stan optimum to ten, który spotyka się z powszechną aprobatą, ponieważ nie kreuje zmian wywołujących konflikty. Ujęcie to było nowatorskie. Nowatorstwo polegało między innymi na tym, że Pareto zrezygnował z oceny zmian dobrobytu, jakie sprawiają, że jednym ludziom powodzi się lepiej, a wskutek tego innym powodzi się gorzej. Następstwem takiego podejścia była rezygnacja z koncepcji jakiegoś jedynego optimum społecznego i ustanowienie w zamian nieskończonej liczby nieporównywalnych optimów ${ }^{19}$.

Pareto był przedstawicielem tzw. ekonomii dobrobytu. Powstała ona na przełomie XIX i XX wieku i jako grupa koncepcji ustalających zasady optymalnego podziału wytworzonego produktu (z punktów widzenia ogólnospołecznego i indywidualnego), stała się początkiem polityki gospodarczej.

Neoliberalna myśl ekonomiczna, która osiągnęła sukces polityczny w końcu XX wieku, uznaje słusznie decydującą rolę rynku. Myślenie w kategoriach dominacji rynku i przy okazji jałowości prób sterowania grą rynkową scharakteryzował już w pierwszej połowie XIX wieku rosyjski pisarz Nikołaj Gogol. Jeden z jego bohaterów mówi: „Fabryki powstaną same z siebie, i powstaną właściwe fabryki, tego, co trzeba miejscowemu człowiekowi. A dalej, o teoretykach gospodarki - ekonomowie polityczni! Dureń na durniu siedzi i durniem pogania. Dalej swego głupiego nosa nie widzi! Osioł, a jeszcze na katedrę wlezie" ${ }^{20}$. W pierwszej połowie XXI wieku neoliberalne polityki gospodarcze prowadzone są przez liczne kraje. Jednym z przykładów jest Brazylia. Kraj ten, będący członkiem tzw. grupy BRICS ${ }^{21}$, typowany na wschodzącą potęgę przeżył kryzys gospodarczy i polityczny. Obecna polityka gospodarcza Brazylii (oparta w dużej części na rabunkowej eksploatacji zasobów przyrodniczych) nakierowana jest przede wszystkim na wzrost ilościowy i parametryczny, czyli na wzrost PKB. Narzędziami są między innymi prywatyzacja, stymulowanie inwestycji wewnętrznych i zagranicznych oraz wolnej konkurencji, a także „uniknięcie nadużywania władzy regulacyjnej przez państwo"22.

Współcześni zwolennicy liberalizmu gospodarczego często sięgają do argumentów prawnych, etycznych, socjologicznych i psychologicznych. Chwalą kreację poczucia odpowiedzialności wśród uczestników wolnej gry rynkowej. Zwracają uwagę na przykład na „optymistyczną wizję natury ludzkiej”23. Powołując się na słowa Friedricha von Hayeka,

18 J.E. Stiglitz, Ekonomia sektora publicznego, PWN, Warszawa 2004, s. 69.

19 M. Blaug, dz. cyt., s. 607.

20 N. Gogol, Martwe dusze, Znak, Kraków 2014, s. 397, 398.

${ }^{21}$ Brazylia, Indie, Chiny, Rosja i Południowa Afryka. Państwa te uznane zostały na początku wieku za wschodzące potęgi gospodarcze. Z czasem obraz ten uległ zmianie. Niektóre z krajów dotknęły kryzysy. Obecnie Brazylia przeprowadza program gospodarczy, który oficjalnie jest określany jako etap odbudowy podstaw gospodarki.

${ }^{22} \mathrm{Na}$ ten temat - H. da Rocha Vianna - ambasador Brazylii w Polsce, Przyspieszyć wzrost, ,Rzeczpospolita”, 14.11.2019.

${ }^{23}$ A. Kociołek-Pęksa, Polityka prawodawcza w obszarze gospodarki w kontekście zasad społecznej gospodarki rynkowej $i$ wolności gospodarczej. Uwagi z zakresu polityki prawa, [w:] J. Osiński, I. Zawiślińska (red.), Polityka publiczna. Teoria. Jakość. Dobre praktyki, Wydawnictwo SGH, Warszawa 2016, s. 71. 
eksponują moralną wartość decyzji podejmowanej w warunkach odpowiedzialności za własne działania. Wreszcie, odnosząc się do angażowania państwa w gospodarkę, uznają, że jest to usuwanie jednej niedoskonałości przez inną, ponieważ państwo jest co najmniej tak ułomne jak rynek ${ }^{24}$. W swojej, niekiedy skrajnej, apologetyce mechanizmów rynkowych nie chcą jednak zauważyć, że kreowanie przez rynek wyłącznie racjonalnych działań jest utopią. Idealny model smithowskiej konkurencji doskonałej istnieje jedynie w teorii. Chodzi tu nie tylko o racjonalność mikroekonomiczną (mit homo oeconomicus), ale też (a może przede wszystkim) o racjonalność w skali makro - w tym również społeczną. Teoretycy rozwoju społeczno-gospodarczego, od Karla Polany'ego i Emile'a Durkheima począwszy, uznali, że idea samodostosowującego się rynku jest utopią, a także, że nie istnieje kompletnie zatomizowane społeczeństwo ${ }^{25}$. Potwierdza to historia gospodarcza świata, która wskazuje, że dotąd nigdzie nie udało się wykreować racjonalnych zachowań zgodnych z ideą homo oeconomicus, nawet na poziomie mikroekonomicznym ${ }^{26}$. Do tego można dodać przytoczoną wcześniej myśl Galbraitha definiującą konkurencję jako grę o sumie zerowej. Fakty są więc uzasadnieniem konieczności wspomagania i korygowania mechanizmów rynku przez instytucje zewnętrzne, czyli państwo (lub w niektórych wypadkach przez instytucje ponadnarodowe) i jego politykę gospodarczą. Niedostatki faktycznie działającej konkurencji i mechanizmów rynkowych stały się przesłanką do poszukiwania alternatywnych mechanizmów alokacji zasobów i zaspokajania potrzeb. Te poszukiwania są zadaniem władzy publicznej. Polityka gospodarcza jest więc formą interwencji państwa w gospodarkę. Jej celem jest korygowanie działań rynku w taki sposób, by poprawić jego efektywność. Sama potrzeba prowadzenia polityki gospodarczej na ogół nie jest kwestionowana (mimo przytoczonych wątpliwości ortodoksyjnych neoliberałów). Spory teoretyczne i praktyczne dotyczą zakresu, celu i narzędzi interwencji oraz warunków realizacji ${ }^{27}$.

Historycznie obserwuje się cykliczne nasilanie (w okresie słabej koniunktury) oraz słabnięcie (w czasie dobrej koniunktury) aktywności państwa w gospodarce. Aktywności rozumianej jako interwencja w życie gospodarcze za pomocą uregulowań polityki ekonomicznej. Początki interwencjonizmu sięgają antyku ${ }^{28}$. Już Ateny, by chronić swój rynek wewnętrzny przed zalewem dóbr obcego pochodzenia, uciekły się do wprowadzenia ceł ochronnych. Można więc uznać, że interwencjonizm jest tak stary jak sama instytucja państwa. O ile aktywność państwa w gospodarce zaczynała się od ochrony wewnętrznego rynku, o tyle współcześnie zadania polityki gospodarczej dotyczą zupełnie innych zagadnień. Po okresie panowania neoliberalizmu (co było konsekwencją kryzysu zapoczątkowanego upadkiem w 2008 roku banku Lehman Brothers Holdings Inc.) rozpoczął się nawrót do idei głębszego zaangażowania państwa w działania gospodarcze. Neoliberalizm, który był przyczyną błędnych i niedostatecznych polityk makroekonomicznych,

24 Tamże, s. 66-70.

25 J. Hausner, Zarzadzanie publiczne, Wydawnictwo Naukowe Scholar, Warszawa 2008, s. 367.

26 R. Sobecki, Interwencjonizm, ale jaki?, „Kwartalnik Nauk o Przedsiębiorstwie” 2019, nr 2.

27 D. Rosati, dz. cyt., s. 19-21.

28 S. Kowalczyk, R. Sobiecki, Interwencjonizm w erze globalizacji, „Kwartalnik Nauk o Przedsiębiorstwie” 2019 , nr 2. 
sprowokował poważne deregulacje wielu niestabilnych dziedzin (w tym usług finansowych). Najważniejszymi obecnie problemami, które próbuje się rozwiązać za pomocą interwencjonizmu, są tzw. koszty zewnętrzne, które w ostatecznym rachunku prowadzą do degradacji środowiska przyrodniczego i społecznego oraz zmian klimatycznych. W sferze społecznej generują przede wszystkim głębokie nierówności dochodowe. Nierówności te mają poważne implikacje zarówno ekonomiczne, jak i społeczne.

Podstawę interwencji państwa w gospodarkę stanowi potrzeba zapewnienia trwałego wzrostu gospodarczego i rozwoju ekonomicznego przez mechanizmy rynkowe. W tej sytuacji państwo ma obowiązek gwarantować podstawy działania rynku (w tym stabilność prawa, stabilność polityczną i otwartość gospodarki). Jednocześnie immanentną cechą rynku jest jego zawodność zarówno jako stała cecha w niektórych obszarach, jak i występująca jednostkowo cecha w innych dziedzinach jako efekt błędów. Wkroczenie państwa w sferę gospodarki jest więc konieczne. Przejawami ułomności rynku są takie zjawiska, jak zawodność konkurencji (monopolizacja), niekorzystne efekty zewnętrzne, ogromna dysproporcja w podziale dochodów, niestabilność ekonomiczna objawiająca się cyklami koniunkturalnymi, pozacyklicznymi kryzysami oraz inflacją i bezrobociem. Poza tymi podstawowymi zjawiskami należy też zauważyć ograniczenia efektywności wynikające $\mathrm{z}$ niepełnej informacji, niekompletność rynku ${ }^{29}$, zawodność wynikającą z istnienia dóbr publicznych (koszt krańcowy ich produkcji = zero oraz brak możliwości wykluczenia kogokolwiek z udziału w korzystaniu z tych dóbr ${ }^{30}$ ). Należy ponadto odnotować, że wymienione przyczyny ułomności rynku są ze sobą powiązane, są współzależne, wzmacniają się nawzajem, działając na zasadzie sprzężeń zwrotnych.

Interwencja państwa $\mathrm{w}$ gospodarce również obarczona jest niedoskonałościami. Pierwszym ich przejawem może być przeregulowanie. Objawia się ono stwarzaniem niekorzystnych warunków dla gospodarowania przez poszczególne podmioty. Osłabia to konkurencję i w rezultacie może doprowadzić do załamania efektywności (optimum) Pareta. Przeregulowanie może być zarówno wynikiem błędów merytorycznych, jak i efektem dążenia do osiągnięcia doraźnych celów politycznych, co w dłuższym okresie może przełożyć się na osłabienie makroekonomicznej sytuacji kraju. Wzmacniaczem w tym przypadku staje się wszechwładna niemal perspektywa cyklów politycznych. Rodzi ona pokusę szkodliwego interwencjonizmu dla uzyskania partykularnych efektów politycznych, partyjnych czy wyborczych. Przykładem działań, kiedy odwołanie do zawodności rynku okazało się skutkiem ułomności interwencji państwa, może być opisana przez J. Stiglitza sprawa wprowadzenia cen minimalnych na produkty rolne ${ }^{31}$. Ceny w rolnictwie

${ }^{29}$ Polega ona na braku dostarczania przez rynek niektórych dóbr mimo ich kalkulacyjnej efektywności. Wymienia się tu jako przykłady rynki finansowe - ubezpieczenia, kredyty (J. Stiglitz, dz. cyt., s. 96). Można do tego zestawienia dodać rynek prywatnych usług medycznych w Polsce w latach 2018, 2019. Ze względu na masowe migracje klientów do prywatnych usługodawców obniża się jakość usług oraz zaczyna brakować możliwości ich realizowania (m.in. z powodu niedoboru personelu).

${ }^{30}$ Podaje się tu przykład latarni morskiej, która dla armatora statku jest darmowa, a więc nie można go zmusić do współfinansowania budowy. W rezultacie latarnia nie powstanie mimo rynkowej potrzeby jej istnienia (J. Stiglitz, dz. cyt., s. 95). Ostatnio zaczyna się na przykład brać pod uwagę możliwość współfinansowania przez pacjentów usług publicznej służby zdrowia, które dotychczas były bezpłatne.

31 J. Stiglitz, dz. cyt., s. 102. 
podlegają silnym wahaniom zarówno sezonowym, jak i długookresowym. Zwykle brak jest możliwości ubezpieczenia tego rodzaju ryzyk. Dodatkowo rynki są wysoce spekulacyjne. Jednak rolnicy interesują się wahaniami cen, o ile wpływają one na ich dochody. Stabilizowanie cen nie w pełni stabilizuje dochód, gdyż ten podlega wpływowi tak cen, jak i podaży towaru. Stabilizacja cen nie wpływa liniowo na wzrost dochodu, a niekiedy efekt może być odwrotny od założeń. W tej sytuacji zawodność rynku jest pretekstem do jego regulowania (przez wprowadzenie cen minimalnych), a nawet przeregulowania w celu osiągnięcia korzyści politycznych. Przykład Stiglitza można wzmocnić obrazkiem z Polski. Wobec obietnic stworzenia Narodowego Holdingu Spożywczego, który będzie kupował płody rolne po cenach „opłacalnych” (krótkookresowo) dla rolników, ekonomista Jerzy Wilkin stwierdza: „to jest gigantyczne złudzenie. [...] Rolnikom będzie lepiej, jak będą się mogli rozwijać. Tworzenie monopoli (holding) polega na niszczeniu konkurencji, a więc pogłębia niedoskonałość rynku"32. W tym przykładzie skupia się kilka omówionych wcześniej zagadnień. Należą do nich: monopolizacja jako element przeregulowania rynku (aż do stopnia możliwej przeciwskuteczności), potrzeba wolnej konkurencji oraz manipulacje w gospodarce jako narzędzie realizacji egoistycznych celów konkretnych polityków, a także krótkookresowa, związana z cyklem politycznym perspektywa.

\section{Społeczna gospodarka rynkowa i ordoliberalizm jako jego podstawa teoretyczna}

Konstytucja Rzeczypospolitej Polskiej w art. 20 stanowi, że: „Społeczna gospodarka rynkowa oparta na wolności działalności gospodarczej, własności prywatnej oraz solidarności, dialogu i współpracy partnerów społecznych stanowi podstawę ustroju gospodarczego Rzeczypospolitej Polskiej" ${ }^{33}$. Tak więc społeczna gospodarka rynkowa jest podstawą ustroju gospodarczego Rzeczypospolitej. Tym samym jest to podstawa polityki gospodarczej RP. Z konstytucyjnego zapisu wynika, że zawarte tam są zarówno warunki gospodarowania (gospodarka rynkowa), jak i realizacja celów społecznych (gospodarka społeczna).

Uznając społeczną gospodarkę rynkową (SGR) za podstawę działalności państwa w gospodarce, a także za ramy działalności podmiotów prywatnych, należy przyjrzeć się teoretycznym podstawom tego systemu gospodarczego.

Społeczna gospodarka rynkowa jest koncepcją z lat 30. (teorie ordoliberalne) i 40. (praktyka) XX wieku. Powstała w Republice Federalnej Niemiec. Wstępem była tu myśl Franza Oppenheimera, że „oparta na własności prywatnej wolność jednostek i rynkowa koordynacja ich działalności gospodarczej mogą być użyte do realizacji celów służących społeczeństwu jako całości"’34. Termin społeczna gospodarka rynkowa stworzył Alfred Müller-Armack, niemiecki ekonomista, który w zakres polityki gospodarczej włączył politykę społeczną jako integralną część. W jego ujęciu ten termin określał system go-

32 J. Solska, Władza za nieróbstwo, „Polityka. Niezbędnik Współczesny” 2019.

33 Dz.U. 1997, nr 78, poz. 483.

34 T. Kaczmarek, P. Pysz, Ludwig Erhard i społeczna gospodarka rynkowa, Instytut Studiów Politycznych PAN, Warszawa 2004, s. 9. 
spodarczy łączący własność prywatną z zasadą sprawiedliwości społecznej. Nazwano to trzecią drogą. Teza o współzależności ładu gospodarczego, politycznego i społecznego rządzących społeczeństwem stała się podstawą idei kolejnego niemieckiego ekonomisty, Waltera Euckena ${ }^{35}$. Opracował on koncepcję nowego ładu gospodarczego Niemiec po drugiej wojnie światowej. Eucken zaproponował wbudowanie rynku w określone ramy systemowe, które miały być narzucane przez państwo. Celem tych ograniczeń było zredukowanie możliwości działania (szczególnie w sferze rynkowej) grup interesu negatywnie wpływających na państwo i społeczeństwo. Opracował zbiór reguł, które określił mianem polityki ramowej. Podstawowym założeniem społecznej gospodarki rynkowej były państwowe gwarancje niezakłóconych procesów rynkowych przy odpowiedniej kontroli i regulacji gospodarki przez państwo. Taki program to ordoliberalizm, a jego początki sięgają lat 30. XX wieku. Był on próbą teoretycznej reakcji na gospodarkę ówczesnego kryzysu ekonomicznego cechującą się nieładem, chaosem i anarchią.

Z perspektywy ordoliberałów zarówno nauka Keynesa, jak i neoliberalne idee szkoły chicagowskiej ${ }^{36}$ mają - wprawdzie rzadko dostrzegane, ale tym niemniej istotne - podobne konsekwencje w razie ich zastosowania ${ }^{37}$. Te odmienne koncepcje polityki gospodarczej cechuje identyczne założenie w odniesieniu do pewnego aspektu tej polityki. Dotyczy ono bezpośredniego oddziaływania państwa na przebieg procesu gospodarowania. Keynesizm jest koncepcją dyskrecjonalnego sterowania przebiegiem procesu gospodarowania przez państwo od strony globalnego popytu poprzez zastosowanie instrumentów polityki fiskalnej i pieniężnej (stopa refinansowa banków komercyjnych). Neoliberalna koncepcja ekonomii podażowej i monetaryzmu proponuje oddziaływanie państwa ukierunkowane na rozmiary zagregowanej podaży oraz stabilność poziomu cen za pośrednictwem instrumentów polityki fiskalnej i podatkowej oraz friedmanowskiej reguły określającej przyrost ilości pieniądza w obiegu w zależności od wzrostu produktu krajowego brutto albo potencjału produkcyjnego gospodarki. Obie szkoły nie brały natomiast pod uwagę możliwości kształtowania (regulowania) ładu gospodarczego, to jest formalnych i nieformalnych reguł gry podmiotów rynkowych.

Najważniejsze różnice teoretyczne między tymi szkołami ekonomicznymi zostały zestawione w tabeli 1 .

35 E. Kundera (red.), Stownik historii myśli ekonomicznej, Wolters Kluwer business, Warszawa 2014, s. 66.

${ }^{36}$ Chicago School of Economics - szkoła ekonomii powstała w latach 30. XX wieku na Uniwersytecie w Chicago, głównymi przedstawicielami są Milton Friedman oraz George Stigler.

37 E. Mączyńska, P. Pysz, Liberalizm, neoliberalizm i ordoliberalizm, Referat na IX Kongres Ekonomistów Polskich, „Ekonomista” 2014, nr 2, http://195.187.97.25:8080/images/data/eko/wydania/No_2_2014/ PAN ekonomista_2014 2 1.pdf\#page $=65$ [dostęp: 27.02.2020]. 
Tabela 1. Ordoliberalizm, neoliberalizm i keynesizm - analiza porównawcza

\begin{tabular}{|c|c|c|c|c|}
\hline \multirow{2}{*}{$\begin{array}{c}\text { Koncepcje polityki } \\
\text { gospodarczej }\end{array}$} & \multirow{2}{*}{$\begin{array}{l}\text { Ład gospodarczy } \\
\text { Kształtowanie ładu }\end{array}$} & \multicolumn{3}{|c|}{ Przebieg procesu gospodarowania } \\
\hline & & $\begin{array}{c}\text { Wymiar } \\
\text { makroekonomiczny }\end{array}$ & $\begin{array}{c}\text { Wymiar } \\
\text { mikroekonomiczny }\end{array}$ & $\begin{array}{c}\text { Jednostki ludzkie } \\
\text { i ich emocje }\end{array}$ \\
\hline Ordoliberalizm & tak & tak & tak & tak \\
\hline Neoliberalizm & nie & tak & tak/nie & nie \\
\hline Keynesizm & nie & tak & nie & tak/nie \\
\hline
\end{tabular}

Źródło: E. Mączyńska, P. Pysz, Liberalizm, neoliberalizm i ordoliberalizm, Referat na IX Kongres Ekonomistów Polskich, „Ekonomista” 2014, nr 2, http://195.187.97.25:8080/images/data/eko/wydania/No_2 2014/PAN_ekonomista_2014_2_1.pdf\#page=65 [dostęp: 27.02.2020].

Analiza porównawcza wyraźnie wskazuje, że ordoliberalizm jako jedyna ze szkół rynkowych wskazuje na możliwość ingerencji państwa w ład gospodarczy. Neoliberalizm neguje wzajemny wpływ jednostek ludzkich i podmiotów w skali mikro na przebieg procesów gospodarczych. W takim ujęciu różnice między spierającymi się o podstawowe zasady szkołami - keynesizmem i neoliberalizmem wydają się niewielkie, ponieważ analiza ta nie uwzględnia skupienia ich uwagi na ekonomii popytowej (keynesizm) i podażowej (neoliberalizm). Tymczasem jest to właśnie aspekt zasadniczo dzielący te szkoły.

Głównym realizatorem praktycznego zastosowania założeń ordoliberalnych został Ludwig Erhard. Erhard i jego ekonomiści teoretycy odrzucili tezy Marksa o antagonistycznej sprzeczności między wolnością gospodarczą a równością i sprawiedliwością społeczną. Uznano, że społeczna gospodarka rynkowa jest syntezą wolności gospodarczej, odpowiedzialności podmiotów gospodarczych i równości społecznej ${ }^{38}$. Bazując na koncepcjach Müller-Armacka i Euckena, Erhard stworzył realnie działającą i przynoszącą szybkie efekty politykę gospodarczą.

Założeniami do wprowadzenia praktycznego było połączenie gospodarki rynkowej z zabezpieczeniem socjalnym. Polityka gospodarcza miała służyć realizacji celów o charakterze ogólnospołecznym oraz zagwarantować zabezpieczenia socjalne, tak by zmniejszyć ryzyko utraty środków do życia przez obywateli. Jako cele SGR widziano zapewnienie możliwie pełnego zatrudnienia, wspieranie regionalnej mobilności siły roboczej, czyli łagodzenie bezrobocia strukturalnego. Stawiano na odbudowę klasy średniej. Po okresie władzy NSDAP demokratyzowano oraz liberalizowano życie polityczne i gospodarcze. Założono ochronę pracy za pomocą regulacji stosunków pracy (regulacje stosunków pracodawca-pracownik) oraz działania na rzecz sprawiedliwego podziału dochodu narodowego przy jednoczesnej dbałości o wzrost wydajności w gospodarce. Był to program realizacji założeń teoretycznych ordoliberalizmu wskazujących na konieczność szerokiej regulacji - kształtowania ładu gospodarczego.

Porównanie nowego erhardowskiego systemu trzeciej drogi z innymi koncepcjami teoretycznymi przedstawia tabela 2 .

${ }^{38}$ T. Kaczmarek, P. Pysz, dz. cyt., s. 105, 111, 112. 
Tabela 2. Społeczna gospodarka rynkowa a kapitalizm typu laissez-faire i socjalizm typu marksistowskiego

\begin{tabular}{|l|l|l|l|}
\hline \multicolumn{1}{|c|}{ Kapitalizm laissez-faire } & \multicolumn{1}{|c|}{ Wolność jednostki } & Nierówność społeczna & $\begin{array}{l}\text { Państwo spełniające w gospo- } \\
\text { darce rolę „stróża nocnego” }\end{array}$ \\
\hline $\begin{array}{l}\text { socjalizm typu } \\
\text { marksistowskiego }\end{array}$ & $\begin{array}{l}\text { wolność jednostki } \\
\text { ograniczona do minimum }\end{array}$ & $\begin{array}{l}\text { równość i sprawiedliwośćc } \\
\text { społeczna* }\end{array}$ & $\begin{array}{l}\text { państwo zarówno kształtuje, } \\
\text { jak i reguluje proces } \\
\text { gospodarczy }\end{array}$ \\
\hline $\begin{array}{l}\text { społeczna gospodarka } \\
\text { rynkowa }\end{array}$ & wolność jednostki & $\begin{array}{l}\text { równość i sprawiedliwośćc } \\
\text { społeczna }\end{array}$ & $\begin{array}{l}\text { państwo ogranicza się } \\
\text { do kształtowania ładu } \\
\text { gospodarczego }\end{array}$ \\
\hline
\end{tabular}

${ }^{*} \mathrm{~W}$ tym wypadku jest to założenie czysto teoretyczne.

Źródło: T. Kaczmarek, P. Pysz, Ludwig Erhard i społeczna gospodarka rynkowa, Instytut Studiów Politycznych PAN, Warszawa 2004, s. 110.

Jak widać z powyższego zestawienia, społeczna gospodarka rynkowa stara się być integracją wybranych elementów z innych typów koncepcji ustrojowych. Fazy czasowe rozwoju polityki SGR oraz ich inspiracje teoretyczne pokazuje tabela 3.

Tabela 3. Fazy polityki społecznej gospodarki rynkowej w Niemczech

\begin{tabular}{|l|l|l|l|}
\hline Zadanie, inspiracje/czas & \multicolumn{1}{|c|}{$1948-1966$} & \multicolumn{1}{|c|}{$1967-1982$} & \multicolumn{1}{c|}{$1982-1998$ i od 1998 } \\
\hline Główne zadanie & $\begin{array}{l}\text { stabilizacja, a nie wzrost } \\
\text { gospodarczy }\end{array}$ & $\begin{array}{l}\text { wzrost gospodarczy po- } \\
\text { przez pobudzanie popytu }\end{array}$ & $\begin{array}{l}\text { wzrost gospodarczy po- } \\
\text { przez ekonomikę podaży }\end{array}$ \\
\hline Inspiratorzy & $\begin{array}{l}\text { Walter Eucken, Ludwig } \\
\text { Erhard, inni ordoliberałowie }\end{array}$ & $\begin{array}{l}\text { John Maynard Keynes, } \\
\text { Walter Eucken }\end{array}$ & $\begin{array}{l}\text { Margaret Thatcher, Ronald } \\
\text { Reagan, Milton Friedman }\end{array}$ \\
\hline
\end{tabular}

* Czołowy przedstawiciel chicagowskiej szkoły ekonomii.

Źródło: T. Kaczmarek, P. Pysz, Ludwig Erhard i spoteczna gospodarka rynkowa, Instytut Studiów Politycznych PAN, Warszawa 2004, s. 140.

Przedstawione zmiany w czasie wyraźnie wskazują na zmienność zarówno celów, jak i ekonomicznych inspiracji. Wskazują też na pełne i szybkie włączenie się gospodarki RFN w światowy system ekonomiczny. Celem pierwszego etapu była odbudowa - stabilizacja ekonomiki po wojennych zniszczeniach. W latach późniejszych Niemcy odniosły błyskawiczny i znaczący na arenie światowej sukces, którego fundamentem była SGR. Tym samym zajęły mocną pozycję w głównym nurcie gospodarczym świata. W przytoczonym zestawieniu wskazuje na to przede wszystkim inspiracja ze strony anglosaskich teoretyków i praktyków najpierw keynesizmu, a następnie neoliberalizmu ${ }^{39}$. Zwrot od lat

39 Zwrot ku inspiracjom neoliberalnym w drugiej połowie XX wieku miał też miejsce w innych niż zachodnioeuropejskie modelach polityki ekonomicznej. Nastąpił on w krajach tzw. rozwijających się (w dużej części postkolonialnych), gdzie programowano forsowny rozwój, związany z planowaniem i nacjonalizacją gospodarki. Elity ekonomiczne ,szybko i radykalnie odeszły od wiary w państwo i socjalizm. Uwierzyły w rynek, wolny handel międzynarodowy i swobodny przepływ kapitału. Zjawisko to rozpoczęło się od wyczerpywania w krajach zachodnich wiary w keynesowski model wzrostu”' (A. Leszczyński, dz. cyt., s. 457). Tę nową rynkową ,wiarę” amerykański badacz ekonomii rozwoju William Easterly uzasadnił: „Bogaci mają rynki, biedni mają biurokrację" (W. Easterly, Brzemię białego człowieka, PWN, Warszawa 2008, s. 139). 
80. XX wieku w stronę inspiracji rodem $\mathrm{z}$ teorii Friedmana, jaki dokonał się w niemieckiej gospodarce, mógłby wydać się zaskakujący. Potwierdza jednak pozycję Niemiec w systemie światowym. Ekonomiczny sukces powojennych Niemiec stał się bodźcem do uznania SGR za ustrój gospodarczy wielu krajów, w tym Polski.

\section{Podstawy teorii polityki gospodarczej: funkcje, cele, instrumenty}

Dyscypliną teoretyczną, formułującą podstawy (szeroko rozumiane cele oraz narzędzia) realizacji polityki gospodarczej jako części polityki państwa jest teoria normatywna polityki gospodarczej. Określając ogólne funkcje tej polityki, można wyróżnić trzy zasadnicze elementy zwane triadą ${ }^{40}$ musgraviańską ${ }^{41}$, takie jak:

1. Funkcja alokacyjna - ma za zadanie kształtowanie wielkości i struktury alokacji zasobów, tak aby usługi i dobra publiczne dostarczone zostały w pożądanej ilości i jakości, jednocześnie ma zostać spełnione kryterium efektywności ekonomicznej, czyli maksymalizacja wartości produktu przy danych zasobach. Kryterium to jest jednym z dwóch możliwych wariantów tzw. zasady racjonalnego gospodarowania. Drugą opcją byłoby osiągnięcie pożądanego/założonego stanu ilościowego i jakościowego produktu przy założeniu minimalizacji poziomu nakładów. Druga opcja może być również uwzględniona przy określaniu pożądanej alokacji zasobów na przykład w wypadku konieczności oszczędzania środków z jednoczesnym zachowaniem założonego poziomu konsumpcji. Obszar tej funkcji to sfera mikroekonomiczna.

2. Funkcja stabilizacyjna - ma zapewnić łagodzenie wahań cyklu koniunkturalnego oraz niwelować występujące niecykliczne szoki popytowe albo podażowe. Jest to funkcja sfery makroekonomicznej.

3. Funkcja redystrybucyjna - ma na celu doprowadzenie do pożądanego podziału dochodu poprzez korektę pierwotnego dochodu za pomocą regulacji podatkowych. Jest tu brany pod uwagę wymiar pozaekonomiczny - społeczny i kryterium sprawiedliwości.

O ile dwie pierwsze funkcje regulują życie gospodarcze, o tyle trzecia wkracza w domenę wyboru politycznego i polityki społecznej.

Cele polityki gospodarczej są wielorakie. Za najważniejsze uznaje się: pełne zatrudnienie, stabilizację cen, sprawiedliwy rozdział dochodów, zrównoważony wzrost gospodarczy, równowagę budżetu i bilansu płatniczego, konkurencyjność gospodarki. Bardziej szczegółowe cele mogą odnosić się do konkretnych sektorów (np. przemysłu czy energetyki). Ponieważ zwykle wszystkich pożądanych stanów nie da się realizować jednocześnie, istotna jest wymienność celów. Cele gospodarcze państwa publikowane są w oficjalnych dokumentach, zawierających konkretne zapisy zamierzeń rządu w obszarze polityki gospodarczej. Są ujmowane zarówno jakościowo, jak i ilościowo. Przykładem

${ }^{40}$ D. Rosati, Polityka gospodarcza. Wybrane zagadnienia, Wydawnictwo SGH, Warszawa 2017, s. 61.

41 Richard Musgrave - ekonomista amerykański niemieckiego pochodzenia. Jego najbardziej cytowaną praca jest The Theory of Public Finance (1959), opisana jako, ,pierwszy anglojęzyczny traktat w tej dziedzinie”Richard Musgrave, https://en.wikipedia.org/wiki/Richard_Musgrave_(economist) [dostęp: 27.02.2020]. 
zapisu jakościowego może być zapowiedź walki z bezrobociem. W tym wypadku uzupełnieniem deklaracji jakościowej jest konkretny wskaźnik ilościowy (na przykład wskazany odsetek liczby bezrobotnych lub dynamika stopy bezrobocia). Skonkretyzowane cele polityki gospodarczej przybierają postać zmiennych matematycznych o określonych wartościach lub bez ustalania tych wartości. Mogą też być przedstawiane jako wartości funkcji agregujących różne zmienne ${ }^{42}$. Prostym przykładem takiego modelu matematycznego jest funkcja użyteczności jako jedna z wielu możliwych metod wyznaczania celów. Określenie społecznej funkcji użyteczności ma postać:

$$
\mathrm{U}=f(x, y) \text {. }
$$

Wartość zależy tu od wielkości jednoczesnej konsumpcji jednego i drugiego dobra przy założeniu osiągnięcia maksimum funkcji przy danych ograniczeniach dotyczących możliwości produkcyjnych w ramach posiadanych technologii. Wartości $x^{*}$ oraz $y^{*}$, dla $U^{*}=$ max stają się wyznaczonymi celami produkcji. Na rysunku 1 przedstawia się to następująco:

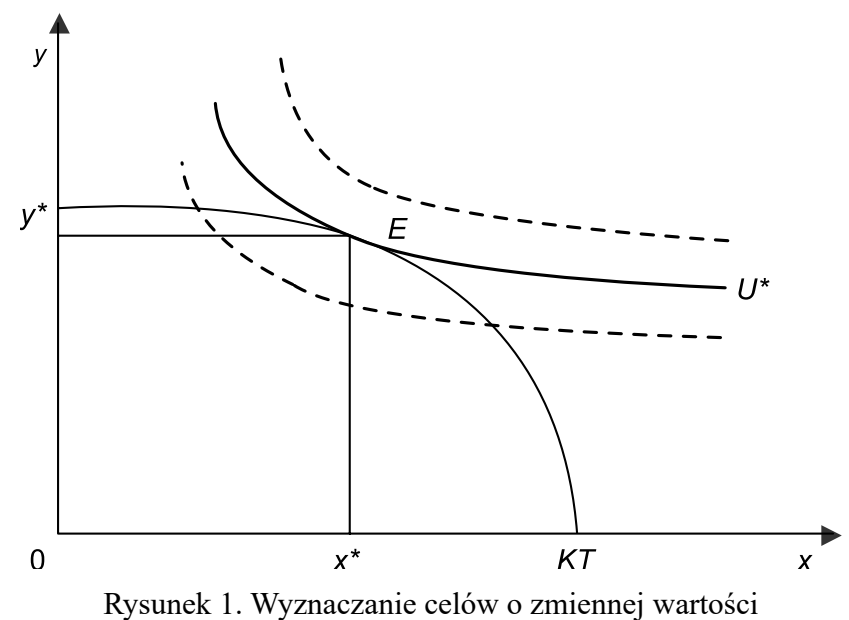

Źródło: D. Rosati, Polityka gospodarcza. Wybrane zagadnienia, Wydawnictwo SGH, Warszawa 2017, s. 67.

Na rysunku widnieje punkt styczności $E$ oraz wklęsła krzywa transformacji $K T$ i najdalej położona krzywa użyteczności $U^{*}$. Wyznaczają one pożądane i możliwe do osiągnięcia cele $x^{*}, y^{*}$. Krzywe $U$ poniżej $U^{*}$ są poziomem użyteczności niższym od $U^{*}$, krzywe $U$ leżące powyżej $U^{*}$ są poza obszarem możliwych rozwiązań.

Skwantyfikowane ilościowo (jak w powyższym przykładzie), czy też przedstawione jakościowo - opisowo, cele są podstawą do określania zmiennych ekonomicznych, technicznych i prawnych. Zmienne te stanowią instrumenty polityki gospodarczej, które rząd kontroluje i kształtuje w taki sposób, aby realizować założone cele. Ze względu na wielość możliwych instrumentów, które wpływają na kształtowanie zmiennych, rząd (przynajmniej na poziomie teoretycznym) dąży do wybrania najskuteczniejszych. Jedną z klasyfikacji instrumentów jest podział na politykę ilościową (zmiana wartości istniejących instrumen-

42 D. Rosati, dz. cyt., s. 66, 67. 
tów), jakościową (nowe instrumenty) i politykę reform (zmiany systemowe) ${ }^{43}$. Tradycyjny jest też podział na instrumenty bezpośredniej ingerencji (zakazy i nakazy, na przykład płace minimalne, limity ilościowe, regulacje cen) oraz na środki oddziaływania pośredniego (zmienne pobudzające podmioty rynkowe do określonych zachowań, na przykład regulacje podatkowe, subsydia). W praktyce stosowany jest też podział instrumentów na wyodrębnione obszary/skale oddziaływania. Są to instrumenty makroekonomiczne (na przykład polityka fiskalna - ustalanie poziomu wydatków i dochodów publicznych, i polityka pieniężna - kontrola i regulacja ilości pieniądza w obiegu) oraz mikroekonomiczne (w tym: podatki, subsydia, i inne regulacje dotyczące funkcjonowania określonych rynków, praw własności pomocy publicznej i regulacji dotyczących stosunków ekonomicznych między poszczególnymi uczestnikami gry rynkowej).

Ponieważ gospodarcza rzeczywistość jest nieskończenie złożona, narzędziem wiążącym cele $\mathrm{z}$ instrumentami polityki ekonomicznej stają się modele upraszczające obraz rzeczywistości. Pierwszym etapem jest tu budowa modelu ekonometrycznego. Opisuje on istniejące zależności między różnymi zmiennymi i przedstawia je w postaci funkcji matematycznej. Modele w postaci strukturalnej analizują zmiany wartości zmiennej objaśnianej (zależnej) od zmian zmiennych niezależnych, których liczba jest ograniczona). Często też pojawia się sytuacja, kiedy zmienne niezależne są jednocześnie także celami polityki. W konsekwencji buduje się tzw. modele zredukowane, gdzie zmiennymi niezależnymi są wyłącznie wielkości niebędące celami polityki. Przykładem takich przekształceń prostego modelu jest jeden z najbardziej popularnych makroekonomicznych modeli ekonometrycznych zwany IS-LM ${ }^{44}$. Część modelu ograniczona do równań równowagi rynku produktów (dla uproszczenia w warunkach gospodarki zamkniętej) przedstawia się w postaci strukturalnej następująco ${ }^{45}$ :

$$
\left.\begin{array}{l}
Y=C+I+G \\
C=a+c Y \\
I=b-g r
\end{array}\right\}
$$

Zmienne oznaczają: $Y$ - dochód, $C$ - konsumpcja, $I$ - inwestycje, $G$ - wydatki publiczne, $r$-stopa procentowa, $a, b, c$ - parametry modelu. Model ten za cele polityki uznaje poziom produkcji = dochodu, i poziom inwestycji. Instrumentami są: $G$-poziom wydatków rządowych i poziom stopy procentowej $-r$. W postaci strukturalnej zmienne pełnią podwójną rolę - objaśnianych i objaśniających. Zmienna celu $Y$ z pierwszego równania jest zmienną objaśniającą w drugim równaniu. Występują tu dwie zmienne celu, dwa instrumenty i aż trzy równania. Oznacza to, że układ można zredukować do dwóch równań. Po przekształceniach:

43 Jest to podział zaproponowany przez holenderskiego ekonomistę Jana Tinbergena.

${ }_{44}$ Model sformułowany przez Johna Hicksa w 1937 roku. Nazwa związana jest z podstawowymi zmiennymi modelu: $I$ - inwestycje, $S$ - oszczędności, $L$ - popyt na pieniądz, $M$ - podaż pieniądza. John Hicks - brytyjski ekonomista, laureat Nagrody Nobla w dziedzinie ekonomii w 1972 roku.

45 D. Rosati, dz. cyt., s. 70-72. 


$$
\left.\begin{array}{l}
Y=[(b-g r)+G+a] /(1-c) \\
I=b-g r
\end{array}\right\}
$$

W zredukowanej postaci cele polityki zależą wyłącznie od instrumentów $(G, r)$ i stałych parametrów $(a, b, c, g)$. Prosty przykład części modelu IS-LM pokazuje, że konstruowanie modeli polityki i warunków jej skuteczności wymaga użycia rozbudowanego warsztatu matematycznego.

Cele i instrumenty polityki powiązane są ze sobą regułami. Wśród istotnych reguł można wymienić przykładowo powiązanie stopy procentowej banku centralnego z dynamiką ilości pieniądza w obiegu oraz regułę uzależniającą wydatki budżetu od poziomu długu publicznego. Zasadność stosowania reguł obarczona jest obciążeniem w postaci trudności lub niemożności przewidzenia przyszłych warunków gospodarowania. Z drugiej strony ewentualna dyskrecjonalność może zwiększyć niepewność na rynku, a postępowanie według ogłoszonych publicznie reguł obniża prawdopodobieństwo podejmowania błędnych decyzji w grach rynkowych. Jan Tinbergen ${ }^{46}$ wykazał związek między liczbą celów a ilością instrumentów polityki. Warunkiem sukcesu polityki jest spełnienie kryterium, by liczba niezależnych instrumentów nie była mniejsza od ilości celów (dla $n$ instrumentów i $m$ celów wymóg skuteczności wskazuje żeby $n \geq m$ ).

Należy zauważyć podstawowe wady modelowania ekonometrycznego. Tak zwana krytyka Lucasa z 1976 roku zwraca uwagę na budzące wątpliwości założenia. W szczególności na nierealne założenie stabilności warunków gospodarowania w kolejnych okresach, na budowanie modeli na podstawie obserwacji z przeszłości oraz na brak uwzględniania sprzężenia zwrotnego między decyzjami politycznymi a decyzjami uczestników operacji rynkowych. Historycznie, zmatematyzowane modele ekonometryczne stały się jednym z kluczowych narzędzi prowadzenia interwencjonistycznej polityki gospodarczej od lat 40. aż po kryzys końca lat 70. XX wieku. Rozkwit rozpoczął się więc w czasach Johna Maynarda Keynesa - twórcy interwencjonizmu państwowego. Charakterystyczne, że sam Keynes podchodził do tych modeli sceptycznie ${ }^{47}$.

\section{Pomiar wyników polityki gospodarczej}

Istotnym zagadnieniem dotyczącym polityki ekonomicznej jest problem pomiaru efektów realizowanej polityki gospodarczej. W kompetencjach rządu lokuje się niewątpliwie formalne przeprowadzenie ewaluacji ex ante (etap projektowania działań), on-going (w trakcie realizacji). Te etapy ewaluacji mogą dotyczyć stanu realizacji poziomu zmiennych zaprogramowanych w polityce. Ewaluacja ex post może być również przeprowadzona jako raport z procesu osiągania poziomu założonych parametrów. Pomimo możliwości analizy parametrów nie da się jednoznacznie sporządzić raportu ex post, który mógłby

46 Jan Tinbergen - holenderski ekonomista i ekonometryk, pionier budowy modeli ekonometrycznych opisujących gospodarki narodowe.

47 D. Coyle, PKB. Krótka, lecz emocjonująca historia, PWN, Warszawa 2018, s. 21. 
zostać przeprowadzony za pomocą wystandaryzowanych metod badawczych i zobiektywizowanych kryteriów. Mnogość teorii ekonomicznych, w różny sposób oceniających pewne wielkości, nie pozwala na sformułowanie jednoznacznych wniosków. Także niepoliczalna jest ilość ocen polityki gospodarczej, które kreują na własny użytek wszyscy uczestnicy rynku. Są to zarówno podmioty wielkoskalowe, jak na przykład rząd i jego agendy, korporacje ponadnarodowe czy narodowe, instytucje finansowe, duże firmy, jak i podmioty działające w małej skali, czyli mikroprzedsiębiorcy, osoby fizyczne i gospodarstwa domowe. Występuje wyraźna nieciągłość skali racjonalności. Rozwiązania racjonalne z punktu widzenia wielkich graczy mogą być nieracjonalne dla indywidualnych podmiotów. Można też jako odrębny poziom wyróżnić racjonalność mezoekonomiczną odnoszącą się do skali regionu i średnich podmiotów.

Najbardziej używanym zarówno w profesjonalnych analizach, jak i w ocenach potocznych wskaźnikiem jest produkt krajowy brutto (PKB). Jest on miarą przepływu produktu w gospodarce w określonym czasie. Ocenia się jego poziom bieżący i dynamikę oraz kierunki zmian. Definicje pojęcia PKB są różne. W realnym świecie nie występuje byt zwany PKB. Jest to twór czysto statystyczny. Sposoby jego wyliczania pokazane są poniżej.

Tabela 4. Trzy sposoby wyliczania PKB

\begin{tabular}{l} 
I. Metoda wartości dodanej (produkcyjna) \\
Produkcja globalna brutto (sprzedaż brutto minus zmiana w stanie zapasów) \\
Minus zużycie pośrednie \\
Wynik: wartość dodana ze wszystkich branż \\
\hline II. Metoda dochodowa (według typów) \\
Suma: $\quad$\begin{tabular}{l} 
wypłat \\
dochodów z wynajmu \\
zysków i dochodów przedsiębiorców \\
podatków od produkcji i importu \\
Minus: subsydia \\
odsetek różnych \\
płatności \\
amortyzacji \\
Wynik: całość dochodu krajowego \\
\hline III. Metoda wydatkowa \\
kuma: \\
konsumpcji gotowych dóbr i usług przez gospodarstwa domowe \\
inwestycji w zakłady, wyposażenie, oprogramowanie \\
wydatków rządowych na dobra i usługi \\
bilans eksportu dóbr i usług (eksport minus import)
\end{tabular} \\
\hline
\end{tabular}

Źródło: D. Coyle, PKB. Krótka, lecz emocjonująca historia, PWN, Warszawa 2018, s. 25.

Statystycznie i księgowo powyższe trzy sposoby są ekwiwalentne. Sumują całość produkcji gospodarki oraz całość jej przychodów albo wydatków. Jest to statystyka brutto nieuwzględniająca amortyzacji zasobów (utraty wartości w czasie). Miernik PKB 
(wcześniej zwany PNB) stworzono do pomiaru działalności gospodarczej, włączając w nią sektor publiczny (ale nie gospodarstwa domowe). Nastąpiło to w związku z rozwojem gospodarek keynesowskich, gdy zmagano się ze skutkami wielkiego kryzysu, a rządy przejęły odpowiedzialność za zarządzanie gospodarką ${ }^{48}$. Wskaźnikiem pochodnym od PKB jest dochód narodowy, zwany też produktem krajowym netto (PKN). Z definicji mierzy on całość dochodów, jakimi rozporządzają mieszkańcy danego kraju w ciągu roku (i to niezależnie od formy prawnej). O ile PKB mierzy całość dóbr i usług wytworzonych w ciągu roku, to PKN pomniejsza się o amortyzację (zużycie kapitału) i powiększa o dochody netto uzyskane za granicą (albo pomniejsza, jeśli wystąpiły dochody netto płacone za granicą). Formuła wygląda następująco: dochód narodowy = produkcja krajowa + dochody netto pochodzace $z$ zagranicy ${ }^{49}$. Należy zauważyć, że PKB jest miarą wzrostu, a nie rozwoju. Mierzy zmiany ilościowe, parametryczne, podczas gdy w okresie obecnych, dynamicznych zmian istotny staje się wzrost. Jest on definiowany jako zmiana jakościowa - systemowa ${ }^{50}$. Zmiana jakościowa gospodarki i przeobrażenia społeczne zanurzone w otoczeniu fizycznym - geograficznym.

PKB jest w tej sytuacji miarą powszechnie znaną i obecnie powszechnie krytykowaną. Można powiedzieć, że „ostatnio [właśnie w obecnym czasie interregnum - WM] pękł z hukiem i trzaskiem balonik mającego ponoć trwać nieprzerwanie i w nieskończoność «wzrostu gospodarczego» mierzonego przyrostem PKB" ${ }^{51}$. Poziom i wzrost PKB jest w stanie współzależności ze zwiększeniem dobrostanu społeczeństwa. Nie każda jednak polityka dążąca do wzrostu PKB wpływa pozytywnie na zadowolenie społeczne. Forsowanie rozwoju mierzonego poziomem i dynamiką produktu robi się coraz bardziej wątpliwe w sytuacji ograbiania planety z zasobów naturalnych i dewastowania środowiska przyrodniczego. To, co się mierzy (tu PKB), nie powinno stawać się celem ${ }^{52}$. Zaznacza się więc tendencja do realokacji wagi mierzonych zjawisk. Znaczenia nabiera ekonomia zrównoważonego rozwoju, która mierzy efekty w kontekście ich wpływu na środowisko przyrodnicze, wprowadzając do kalkulacji nowe zmienne - stan środowiska i zasobów naturalnych, traktowany jako kapitał przyrodniczy. Problemem ludzkości stała się gospodarka nadkonsumpcji i nadprodukcji. W 2008 roku pojawił się ruch Research and Degrowth $^{53}$. Patronem intelektualnym ruchu jest ekonomista Nicolas Georgescu-Roegen ${ }^{54}$, który opublikował manifest The Entropy Law and the Economic Process (Prawo entropii a proces ekonomiczny). Jego stanowisko, w największym skrócie, mówi, że procesu entropii nie da się odwrócić, ale należy go spowolnić. W konsekwencji miary sukcesu należy odnosić do biofizycznego stanu ludzi - zapewnić maksymalnie możliwy poziom

48 J. Stiglitz, A. Sen, J.P. Fitoussi, Błąd pomiaru. Dlaczego PKB nie wystarcza, Polskie Towarzystwo Ekonomiczne, Warszawa 2013, s. XXXIII.

49 T. Piketty, Kapital w XXI wieku, Wydawnictwo Krytyki Politycznej, Warszawa 2015, s. 62.

50 J. Hausner, Zarzadzanie publiczne, Wydawnictwo Naukowe Scholar, Warszawa 2008, s. 370.

${ }^{51}$ A. Leszczyński, Skok $w$ nowoczesność. Polityka wzrostu w krajach peryferyjnych 1943-1980, Wydawnictwo Krytyki Politycznej, Warszawa 2013, s. 10.

${ }^{52}$ M. Piątkowski, Europejski lider wzrostu, Poltext, Warszawa 2019, s. 368.

53 Nazwa degrowth może być tłumaczona na polski jako od-wzrost lub wycof.

54 A. Leszczyński, Eksperymenty na biednych, Wydawnictwo Krytyki Politycznej, Warszawa 2016, s. $195,196$. 
zadowolenia z życia przy minimalnym zużyciu zasobów. Stanowisko takie jest wręcz sprzeczne z ekonomią neoklasyczną, która nie potrafi wycenić na przykład wolnego czasu, uważając go za koszt zmniejszający wydajność i produkcję. Jest też sprzeczne z ogólnie przyjętą zasadą racjonalnego gospodarowania. Zasada ta mówi albo o minimum nakładów przy osiąganiu założonego efektu, albo o maksymalizacji efektu przy założonych nakładach. Tymczasem Georgescu-Roegen ustala miarę dążącą jednocześnie do osiągania minimów i maksimów funkcji.

Istnieją więc związane z coraz aktualniejszymi problemami zmiany społecznej, inne niż PKB narzędzia pomiaru efektów polityki gospodarczej państwa i oceny jej wpływu na dobrostan społeczeństwa. Można je klasyfikować z uwagi na dziedzinę życia gospodarczego, którą mierzą (w tym między innymi produkcja, bezrobocie, inwestycje - analizowane pod kątem wolumenu, dynamiki, kierunków zmian, wydajność pracy, wskaźnik ze sfery finansów). Wskaźniki ekonomiczne mogą być oceniane i konstruowane z punktu widzenia różnych nurtów myśli ekonomicznej. Inaczej ocenią efekty i plany polityki gospodarczej ortodoksyjni wolnorynkowcy, a inaczej zwolennicy transferów socjalnych. W ocenie polityki ekonomicznej coraz ważniejsze są wskaźniki ściśle powiązane ze sferą społeczną. Pozostaje to w korelacji z pozaekonomicznymi politykami społecznymi oraz w ścisłym powiązaniu z rosnącą wagą problemu nierówności społecznych. Zauważono, że „długotrwała tendencja rozwojowa społecznych nierówności ulegać zaczyna odwróceniu [...] rozstęp standardów życiowych między krajami «rozwiniętymi» a «zacofanymi» czy «rozwijającymi się gospodarczo» kurczy się, gdy nierówności społeczne wewnątrz krajów «rozwiniętych» rosną znowu jak za dawnych i, zdawałoby się, na zawsze minionych lat, a przytem rosną w nigdy przedtem nienotowanym tempie i jak dotąd niepohamowanie" 55 . Wśród wskaźników mierzących aspekty społeczne polityki gospodarczej wymienić można:

1. Wskaźnik Giniego służący do liczbowego wyrażania nierównomiernego rozkładu dóbr, zwłaszcza dochodu (na przykład gospodarstw domowych). Problemem globalnym staje się narastający wzrost nierówności społecznych, zasygnalizowany na przykład przez Thomasa Piketty'ego ${ }^{56}$. Jest to nierówność fundamentalna, wyrażona związkiem liczbowym: $r>g$, gdzie $r$ jest wskaźnikiem rentowności kapitału, a $g$ oznacza przyrost produkcji i dochodu (stopa wzrostu). Kiedy rentowność (stopa zwrotu) kapitału znacząco przerasta stopę wzrostu (a jest to stała tendencja w XXI wieku), przychody z kapitału rosną szybciej niż gospodarka jako całość. Na skutek prawa skumulowanego wzrostu w długim terminie kreuje to nadzwyczaj silne efekty destabilizujące strukturę nierówności społecznych. Nasuwa się wniosek, że istnieje pilna potrzeba stworzenia polityk publicznych, mieszczących się w dziedzinie polityki gospodarczej, pozwalających przeciwdziałać skutkom tego zjawiska. Potrzebna jest korekta - wyższe podatki, większa redystrybucja dóbr. „Systemy demokratyczne z gospodarką rynkową radziły sobie najlepiej, gdy elity z wielkimi pieniędzmi miały poczucie społecznej odpowiedzialności’’57.

55 A. Leszczyński, dz. cyt., s. 11.

56 T. Piketty, dz. cyt., s. 41-43, 101.

57 R. Nowicki, Wywiad z Fukuyama. Liberalizm nie jest przeżytkiem, „Newsweek Polska” 2019, nr 42. 
2. Niedawno stworzony indeks lepszego życia $\mathrm{OECD}^{58}$, klasyfikujący kraje z holistycznego punktu widzenia ogólnej satysfakcji obywateli. Przypisuje on wagi takim tematom, jak dochody, służba zdrowia, bezpieczeństwo, mieszkanie. Uwzględnia oczywiście coraz bardziej istotny aspekt, jakim jest poziom dewastacji środowiska.

3. Pomiar relacji dochodów gospodarstw domowych do ich sztywnych wydatków (jeden ze wskaźników społecznych). Ten konkretny pomiar koresponduje z empirycznym prawem Engla mówiącym (w skrócie), że w miarę wzrostu dochodów maleją względne wydatki na żywność.

Problemy ubóstwa i nierówności społecznych (w konsekwencji i ekonomicznych) stały się na tyle istotne, że w 2019 roku nagrodę Szwedzkiego Banku Narodowego w dziedzinie nauk ekonomicznych otrzymało trzech ekonomistów: Abhijit Banerjee, Esther Duflo i Michael Kremer, „za eksperymentalne podejście do łagodzenia światowego ubóstwa”. Ciekawy, kilkunastominutowy wykład o swoich badaniach ubóstwa wygłosiła Duflo i, co charakterystyczne, został on umieszczony na popularnym i powszechnie oglądanym kanale internetowym YouTube. Zdaje się to świadczyć o rosnącym coraz bardziej zainteresowaniu problematyką ${ }^{59}$.

Ciekawą uwagę, niejako podsumowującą powyższe rozważania na temat polityki gospodarczej, przedstawił prezydent Francji Nicolas Sarkozy: „Jeśli nie przypiszemy żadnej wartości księgowej jakości służb publicznych, jeśli ograniczymy się do indeksu postępu ekonomicznego, który zawiera tylko to, co jest tworzone, a nie to, co jest niszczone, oraz jeśli skoncentrujemy się tylko na produkcie krajowym brutto [...] jak możemy oczekiwać, że zrozumiemy, co właściwie robimy i jak zmierzymy się z konsekwencjami? Rodzaj cywilizacji, jaką budujemy, zależy od sposobu, w jaki księgujemy, a to dlatego, że zmienia się wartość, jaką przypisujemy rzeczom"60.

\section{Bibliografia}

Bińczyk E., Epoka człowieka. Retoryka i marazm antropocenu, PWN, Warszawa 2018.

Blaug M., Teoria ekonomii. Ujęcie retrospektywne, PWN, Warszawa 2000.

Carr N., Ptytki umyst. Jak internet wpływa na nasz mózg, Wydawnictwo Helion, Gliwice 2013.

Coyle D., PKB. Krótka, lecz emocjonująca historia, PWN, Warszawa 2018.

da Rocha Vianna H., Przyspieszyć wzrost, ,Rzeczpospolita”, 14.11.2019.

Duczkowski N., Stwórz sobie lepsze życie, https://prnews.pl/stworz-sobie-lepsze-zycie-18883 [dostęp: 11.10.2019].

Easterly W., Brzemię białego człowieka, PWN, Warszawa 2008.

\footnotetext{
${ }^{58}$ N. Duczkowski, Stwórz sobie lepsze życie, https://prnews.pl/stworz-sobie-lepsze-zycie-18883 [dostęp: 11.10.2019].

${ }^{59}$ Esther Duflo: Social experiments to fight poverty, https://www.youtube.com/watch?v=0zvrGiPkVcs [dostęp: 18.11.2019].

${ }^{60}$ N. Sarkozy, Stowo wstępne, [w:] J. Stiglitz, A. Sen, J.P. Fitoussi, Btad pomiaru. Dlaczego PKB nie wystarcza, Polskie Towarzystwo Ekonomiczne, Warszawa 2013, s. XXI, XXXIII.
} 
Esther Duflo: Social experiments to fight poverty, https:/www.youtube.com/watch?v=0zvrGiPkVcs [dostęp: 18.11.2019].

Galbraith J.K., Społeczeństwo dobrobytu. Państwo przemysłowe, PIW, Warszawa 1973.

Gogol N., Martwe dusze, Znak, Kraków 2014.

Hausner J., Zarzadzanie publiczne, Wydawnictwo Naukowe Scholar, Warszawa 2008.

Kaczmarek T., Pysz P., Ludwig Erhard i społeczna gospodarka rynkowa, Instytut Studiów Politycznych PAN, Warszawa 2004.

Konstytucja Rzeczypospolitej Polskiej z dnia 2 kwietnia 1997 r., Dz.U. 1997, nr 78, poz. 483.

Kowalczyk S., Sobiecki R., Interwencjonizm w erze globalizacji, „Kwartalnik Nauk o Przedsiębiorstwie" 2019, nr 2.

Kundera E. (red.), Słownik historii myśli ekonomicznej, Wolters Kluwer business, Warszawa 2014.

Leszczyński A., Eksperymenty na biednych, Wydawnictwo Krytyki Politycznej, Warszawa 2016.

Leszczyński A., Skok w nowoczesność. Polityka wzrostu w krajach peryferyjnych 1943-1980, Wydawnictwo Krytyki Politycznej, Warszawa 2013.

Malthus T.R, Prawo ludności, Jirafa Roja, Warszawa 2007.

Maslin M., Zmiany klimatu, Wydawnictwo Uniwersytetu Łódzkiego, Łódź 2018.

Mączyńska E., Pysz P., Liberalizm, neoliberalizm i ordoliberalizm, Referat na IX Kongres Ekonomistów Polskich, „Ekonomista”2014, nr 2, http://journals.pan.pl/dlibra/publication/100904/ edition/86921/content [dostęp: 27.02.2020]

Nowicki R., Wywiad z Fukuyama. Liberalizm nie jest przeżytkiem, „Newsweek Polska” 2019, nr 42.

Osiński J., Zawiślińska I. (red.), Polityka publiczna. Teoria. Jakość. Dobre praktyki, Wydawnictwo SGH, Warszawa 2016.

Piątkowski M., Europejski lider wzrostu, Poltext, Warszawa 2019.

Piketty T., Kapital w XXI wieku, Wydawnictwo Krytyki Politycznej, Warszawa 2015.

Richard Musgrave, https://en.wikipedia.org/wiki/Richard Musgrave (economist) [dostęp: 27.02.2020].

Rosati D., Polityka gospodarcza. Wybrane zagadnienia, Wydawnictwo SGH, Warszawa 2017.

Sarkozy N., Słowo wstępne, [w:] J. Stiglitz, A. Sen, J.P. Fitoussi, Bład pomiaru. Dlaczego PKB nie wystarcza, Polskie Towarzystwo Ekonomiczne, Warszawa 2013.

Smith A., Badania nad natura i przyczynami bogactwa narodów, PWN, Warszawa 2007.

Sobecki R., Interwencjonizm, ale jaki?, „Kwartalnik Nauk o Przedsiębiorstwie” 2019, nr 2.

Solska J., Władza za nieróbstwo, „Polityka. Niezbędnik Współczesny” 2019.

Stankiewicz W., Historia myśli ekonomicznej, PWE, Warszawa 2000.

Stiglitz J.E., Ekonomia sektora publicznego, PWN, Warszawa 2004. 
Stiglitz J., Sen A., Fitoussi J.P., Bład pomiaru. Dlaczego PKB nie wystarcza, Polskie Towarzystwo Ekonomiczne, Warszawa 2013.

Wilkin J., Instytucjonalne i kulturowe podstawy gospodarowania, Wydawnictwo Naukowe Scholar, Warszawa 2016.

Żmigrodzki M. (red. nauk.), Encyklopedia politologii, t. 1, Kantor Wydawniczy Zakamycze, Kraków 1999.

\section{Streszczenie}

Polityka gospodarcza jako działanie państwa na tle globalnych zmian

Na tle dynamicznych globalnych zmian społecznych, a także zmian w środowisku biogeograficznym, jedną z ważnych ról państwa jest jego działanie jako regulatora życia gospodarczego. Polityka gospodarcza jest narzędziem państwa w tej dziedzinie. Celem artykułu jest przedstawienie jednego z modeli polityki gospodarczej - polityki społecznej gospodarki rynkowej na tle powstawania nowej rzeczywistości pierwszej połowy XXI wieku.

Słowa kluczowe: zmiany społeczne, działanie państwa, polityka gospodarcza

\section{Summary}

\section{Economic policy as a state action against the backdrop of global changes}

Against the backdrop of dynamic global social changes, as well as changes in the biogeographic environment, one of the important roles of the state is as a regulator of economic life. Economic policy is a state tool in this field. The aim of the article is to present one of the economic policy models - social market economy policy, against the background of creating a new reality for the first half of the $21^{\text {st }}$ century.

Keywords: social changes, state activity, economic policy 


\section{Patriotyzm ekonomiczny - droga do wzmocnienia gospodarki czy droga donikąd?}

\section{Wstęp}

Patriotyzm gospodarczy, deklarowany i odmieniany na wszelkie sposoby, robi ostatnio furorę w prorządowych, czyli „narodowych”, a niegdyś publicznych, mediach, w dyskusjach publicystów oraz w wypowiedziach funkcjonariuszy polskiego rządu. Warto więc, a nawet trzeba, postawić pytanie o to, czy i jak być gospodarczym patriotą? Czy patriotą gospodarczym jest ktoś, kto za samo zło uznaje wszystko to, co jest inne, obce, bo pochodzi spoza naszych granic i nie jest generowane przez polskich pracowników, menedżerów i właścicieli (przedsiębiorców)?

Patriotyzm ekonomiczny to podejmowanie świadomych decyzji ekonomicznych z uwzględnieniem pozytywnego wpływu tych wyborów na wspólnotę narodową (państwową), z którą dany podmiot się identyfikuje ${ }^{1}$. Jako decyzje ekonomiczne należałoby rozumieć nie tylko zakupy towarów (dóbr konsumpcyjnych) czy korzystanie ze świadczonych przez rodzime podmioty usług, ale również wybieranie krajowych dostawców i kooperantów. Patriotyzm ten nie dotyczy zatem wyłącznie konsumentów, ale także podmiotów gospodarczych, jak i urzędów publicznych.

Dyskusja o patriotyzmie gospodarczym zaczęła się w Polsce już przed wielu laty, a zaktywizowała w okresie ostatnich kilku lat, zwłaszcza w czasie globalnego kryzysu finansowego. Nie jest więc-jak o tym zapewniają rządowi funkcjonariusze w reżimowych

${ }^{1}$ T. Dziewulski, Patriotyzm ekonomiczny - czy to ma sens?, https://wspieramrozwoj.pl/artykul/82/patriotyzm-ekonomiczny-czy-ma-sens [dostęp: 19.02.2020]. 
mediach - autonomicznym dziełem „dobrej zmiany”2. Patriotyzm gospodarczy nie jest też absolutnie koncepcją nową, a jego światowa historia sięga co najmniej początków rewolucji przemysłowej, zatem XVIII wieku, jeśli nie okresu jeszcze wcześniejszego. W Polsce koncepcja ta zyskała na popularności po odzyskaniu niepodległości w 1918 roku, przejawiając się choćby w wyraźnym wsparciu rozbudowy polskiej gospodarki, głównie przemysłu, a także wielkich inwestycji infrastrukturalnych, będących przedmiotem narodowej dumy ${ }^{3}$.

Z nastaniem ,dobrej zmiany” hasło patriotyzmu gospodarczego stało się jednak jednym z najczęściej głoszonych. Powstać miał zatem plan rozwoju Polski na najbliższe ćwierćwiecze, według którego nasza gospodarka miała być silna przede wszystkim kapitałem krajowym ${ }^{4}$. Otoczenie polskiego biznesu miało zaś stać się lepsze, a warunki działania „przewidywalne i transparentne”. Polskim przedsiębiorcom miałby w trudnych warunkach krajowej i międzynarodowej konkurencji pomagać specjalny fundusz rozwoju - powstały z połączenia kilku instytucji, m.in. KUKE, BGK, PARP ${ }^{5}$. Oczywiście gdyby nie dzisiejsza znajomość realnych działań ekipy „dobrej zmiany” i jej popleczników w gospodarce, można by przyjąć tę deklarację jako poważną zmianę na lepsze, choć zmiany te nie oznaczałyby automatycznie wdrożenia zasad gospodarczego patriotyzmu.

Współcześnie patriotyzm jako zjawisko społeczne przestał być bezwzględnie wymagany przez świat polityki; jest on wszelako jednostce nadal bardzo potrzebny, zwłaszcza dla własnego komfortu psychicznego, bo - w świecie postępującej indywidualizacji jednostka potrzebuje jakiejś wyraźnej grupy odniesienia, potrzebuje też poczucia więzi i tożsamości ${ }^{6}$. W dzisiejszym świecie ojczyzna nie wymaga od nas tradycyjnych postaw patriotycznych, pełnych heroizmu, lecz to wymagania naszej duchowej tożsamości powodują, że musimy być patriotami, jeżeli chcemy zachować swoją tożsamość.

Dziś zatem jedną z najważniejszych form patriotyzmu jako takiego staje się patriotyzm gospodarczy, który - na poziomie najbardziej ogólnym - oznacza dbałość o dobrą kondycję gospodarczą krajuํ. Cóż jednak oznacza to w gospodarczej praktyce? Na tę kwestię warto spojrzeć zarówno z punktu widzenia nabywcy dóbr i usług, jak i jego wytwórcy oraz aparatu państwowego jako regulatora rynku.

Artykuł ma na celu przede wszystkim określenie dzisiejszego znaczenia patriotyzmu ekonomicznego (bądź - zamiennie - gospodarczego) z perspektywy obu stron kontaktów rynkowych, a więc konsumenta (nabywcy) i producenta (dostawcy). Jest to o tyle istotne, iż nie można patrzeć na tę, jakże istotną, kwestię wyłącznie z perspektywy na-

2 E. Mączyńska-Ziemacka, T. Maćkowiak, Dobre, bo polskie, http://miesiecznik.wdrodze.pl/index. php?mod=archiwumtekst\&id=16198\#.XoloynLgrIV [dostęp: 19.02.2020].

3 J. Zielazna, Nasza ekonomia to drogi i bezdroża, wywiad z prof. Elżbietą Mączyńska, https://plus.pomorska.pl/nasza-ekonomia-to-drogi-i-bezdroza/ar/9957512 [dostęp: 10.03.2020].

${ }^{4}$ L. Kostrzewski, P. Miączyński, Patriotyzm gospodarczy robi furorę w mediach. Będa zmiany w prawie, http:// wyborcza.biz/biznes/1,147584,19980984,patriotyzm-gospodarczy-robi-furore-w-mediach-beda-zmiany-w.html [dostęp: 19.02.2020].

5 Tamże.

${ }^{6}$ Ł. Skoczylas, Patriotyzm konsumencki: próba spojrzenia socjologicznego, „Ruch Prawniczy, Ekonomiczny i Socjologiczny" 2013, z. 4, s. 216.

7 E. Mączyńska-Ziemacka, T. Maćkowiak, dz. cyt. 
bywcy - bo zacieśnia to perspektywę badawczą wyłącznie do zjawiska etnocentryzmu konsumenckiego. Wobec powyższego podjęto próbę pewnego określenia (bo przecież nie zdefiniowania) obu pojęć, znalezienia ich cech wspólnych, ale też wskazania istotnych różnic pomiędzy nimi.

W opracowaniu starano się również wskazać na możliwość poszukiwania (czy znalezienia? - to pozostaje wciąż kwestią dyskusyjną) pewnego balansu między skrajnymi postawami rynkowymi, tj. ekonomicznym kosmopolityzmem a nacjonalizmem gospodarczym. Wydaje się bowiem, że jakiekolwiek skrajności w postawach i zachowaniach o podłożu rynkowym są, zwłaszcza współcześnie, słabo przystające do dzisiejszej rzeczywistości gospodarczej.

\section{Perspektywa konsumenta}

Społeczeństwo konsumpcyjne, a więc takie, które się u nas kształtuje, ocenia swoich członków na podstawie ich zachowań konsumenckich ${ }^{8}$. Konsumpcja może być zjawiskiem niesprzyjającym patriotyzmowi, może być wobec niego neutralna, ale też może stanowić jego przejaw - wszystko zależy od nie tylko deklarowanych, ale i realizowanych w praktyce postaw, wyborów, działań.

Patriotyzm konsumentów w Polsce, w warunkach globalizacji, ulegał dynamicznej zmianie9. Dzięki każdej świadomej decyzji konsumenckiej możemy przyczynić się do tego, że kapitał pozostanie w kraju, a to z kolei pozwala producentom na rozwój oraz tworzenie nowych miejsc pracy ${ }^{10}$. Szczególnie więc w handlu wielu przedsiębiorców, zwłaszcza działających od wielu lat, chętnie eksponuje i podkreśla swoją polskośćc ${ }^{11}$.

Polacy rzeczywiście coraz bardziej i coraz częściej interesują się pochodzeniem nabywanych produktów: przez to chcą być świadomymi konsumentami i wybierać rodzime artykuły, choć - przy napływie zagranicznych towarów - często nie są w stanie odróżnić polskich marek od marek obcych ${ }^{12}$.

Patriotyzm gospodarczy to oczywiście także decyzje konsumenckie, wybór polskich produktów $^{13}$, promowanie ich, bo kreując modę na polskie produkty, możemy zrobić wiele dobrego dla polskiej gospodarki ${ }^{14}$. W wypadku konsumentów oznacza to, że we wszystkich swoich zachowaniach rynkowych, a zwłaszcza w trakcie dokonywania zakupów

\footnotetext{
8 Ł. Skoczylas, dz. cyt., s. 216.

9 K. Włodarczyk, Globalizacja a patriotyzm ekonomiczny polskich konsumentów, „Studia Ekonomiczne. Zeszyty Naukowe Uniwersytetu Ekonomicznego w Katowicach”2015, nr 214, s. 69 i nast.

10 Patriotyzm gospodarczy a decyzje zakupowe Polaków, https://biznes.newseria.pl/komunikaty/patriotyzm-gospodarczy-a,b2026028150 [dostęp: 19.02.2020].

11 Szerzej w: K. Kaszuba, Patriotyzm przy sklepowej półce, „Wiadomości Handlowe” 2013, nr 9(128).

12 Patriotyzm gospodarczy..., dz. cyt.

13 A. Tycner, Patriotyzm gospodarczy nie równa się walce z zagranicznym kapitałem, http://finanse.wnp. pl/patriotyzm-gospodarczy-nie-rowna-sie-walce-z-zagranicznym-kapitalem, $273028 \quad 1 \quad 0 \quad 0 . h t m l$ [dostęp: 19.02.2020].

14 J. Kowalczyk, Co oznacza „patriotyzm gospodarczy” dla Polaków, https://www.pb.pl/co-oznacza-patriotyzm-gospodarczy-dla-polakow-868098 [dostęp: 19.02.2020].
} 
towarów oraz usług powinni kierować się wyłącznie korzyściami dla swojego kraju ${ }^{15}$. Często jednakże konsumentom brakuje wiedzy, gdy nie mogą odnaleźć informacji, czy produkt jest krajowy, czy też zagraniczny.

Patriotyzm ekonomiczny nie musi też oznaczać kupowania rodzimych (krajowych) produktów za wszelką cenę, a więc również tych zbyt drogich lub niskiej jakości, tylko dlatego, że są polskie ${ }^{16}$.

„Nowy” patriotyzm konsumencki to w istocie bardziej poświęcenie dla konkretnej marki lub przedsiębiorstwa. Kupując określone produkty, możemy mieć poczucie, że wspieramy „narodowy” przemysł, ale bezpośrednio wspieramy tylko właścicieli (i - jedynie w pewnym stopniu, wcale nie zawsze - pracowników) danego przedsiębiorstwa. Przedsiębiorstwa wykorzystują zresztą ten trend patriotyczny, tworząc marki „,narodowe”, które wprost odwołują się do wartości związanych z poczuciem przynależności do narodu ${ }^{17}$.

Marka narodowa stanowi szczególny rodzaj marki, zorientowanej na zaspokojenie określonych potrzeb emocjonalnych klienta, wynikających z silnie wykształconego u niego poczucia tożsamości i dumy narodowej. Tworzenie takiej marki umożliwia przedsiębiorcom wyróżnianie ich produktu spośród wielu innych produktów globalnych; ponadto może wpłynąć na zmniejszenie kosztów marketingowych w wyniku utożsamienia z ich produktami pewnych powszechnie znanych i cenionych symboli, związanych pierwotnie $\mathrm{z}$ narodem.

Marka narodowa stanowi także odpowiedź na powstanie społeczeństwa konsumpcyjnego, w którym dóbr jest dużo, problemem pozostaje natomiast popyt na nie - aby go wytworzyć, trzeba odwoływać się do emocji klienta, a nie tylko do argumentów racjonalnych. Tworzenie marek narodowych jest więc swoistą odpowiedzią na zmiany w społeczeństwach zachodniego kręgu kulturowego, których częścią jest wytworzenie się ,nowego" patriotyzmu ${ }^{18}$.

Pewnym wyjaśnieniem wzrastającej popularności polskich produktów może być odczuwana przez rzesze ludzi nostalgia za przeszłością, również za tą związaną z czasami PRL, która nie jest wcale tak jednoznacznie źle oceniana. Producenci mogą więc korzystać bądź z tego, że pewne produkty dostępne są od wielu lat, bo sprzedawane były także w czasach PRL, bądź z tego, że dużej liczbie konsumentów kojarzą się z okresem dzieciństwa i młodości ${ }^{19}$.

Nie można jednak patriotyzmu gospodarczego sprowadzać tylko do etnocentryzmu konsumenckiego, do tego, by nabywać wyłącznie, bądź przede wszystkim, polskie produkty. Problem jest w istocie jeszcze bardziej złożony.

15 K. Włodarczyk, dz. cyt., s. 67.

16 S. Ostrowski, Patriotyzm ekonomiczny to nie jest kupowanie produktu tylko dlatego, że jest polski, https://biznesnaostro.pl/patriotyzm-ekonomiczny-to-nie-jest-kupowanie-produktu-tylko-dlatego-ze-jest-polski/ [dostęp: 19.02.2020].

17 Ł. Skoczylas, dz. cyt., s. 219.

18 Tamże, s. 220.

19 Tamże. 
Sama zasada etnocentryzmu konsumenckiego jest przy tym na pozór, ale tylko na pozór, bardzo prosta - chodzi o wybieranie tego, co polskie, zamiast tego, co zagraniczne ${ }^{20}$. Cóż jednak znaczy dziś, w dobie globalizacji i dominacji na światowych rynkach korporacji transnarodowych (KTN), pojęcie ,polskiego” produktu? Czy gospodarczym patriotą jest więc ktoś, kto nawet kupuje produkty pochodzące od polskich producentów, ale w obcych hipermarketach, czy może dokonujący zakupów w „,polskich” sklepach, ale wybierający $\mathrm{w}$ nich towary pochodzenia zagranicznego?

Czynnikiem, który zasadniczo komplikuje dokonywanie wyborów konsumenckich w Polsce (ale w czasach globalizacji również w innych krajach), jest nie zawsze klarowne rozgraniczenie tego, które marki są „,polskie”, a które „,zagraniczne”21.

Niewystarczające zrozumienie złożoności współczesnej gospodarki prowadzi zatem do paradoksalnych sytuacji. Jakże niedawno bowiem środowiska utożsamiane z ekonomicznym patriotyzmem, a przynajmniej same siebie tak określające (choć jest to określenie dalekie od prawdy), zaczęły powielać tzw. efekt 590. Również reżimowe media, opanowane przez ludzi nienawykłych do prawdomówności, zaczęły powielać fałszywą informację, jakoby to właśnie ów prefiks 590 w kodzie kreskowym pozwalał jednoznacznie zidentyfikować ,prawdziwie polski” produkt. Problem wszakże w tym, iż liczba ta określa wyłącznie miejsce rejestracji działalności gospodarczej - i nic ponadto. W wielu wypadkach oznacza to zaś spółki-córki zagranicznych koncernów, tworzące miejsca pracy w odległych krajach i transferujące zyski do swych oddziałów macierzystych ${ }^{22}$. Dzięki nasilonej propagandzie jakże doskonale przyjmują się w społecznej świadomości myślowe protezy, skutecznie uzupełniające (wypełniające) intelektualne deficyty.

W kontekście patriotyzmu konsumenckiego ważną kwestią wydaje się także swoisty konsumencki patriotyzm lokalny, czyli preferowanie produktów z danego regionu wobec szerokiej oferty dóbr nie tylko globalnej, lecz także ogólnokrajowejej

Wielu z nas, myśląc o patriotyzmie ekonomicznym, nastawia się na robienie zakupów w lokalnych sklepach, zwanych nieraz potocznie osiedlowymi czy rodzinnymi ${ }^{24}$.

Sprawa wydaje się poniekąd słuszna, bo w końcu wspieramy w ten sposób swoich bezpośrednich sąsiadów, często znajomych, a nie wielkie markety i zagraniczne sieci handlowe (byłby to wszelako patriotyzm lokalny, uznawany czasem za przeciwieństwo „prawdziwego" patriotyzmu).

Problem jest w tym, że te najmniejsze sklepiki przeważnie mają w swoim asortymencie głównie produkty będące wytworami wielkich korporacji, często wytwarzane za granicą, a pozbawione są produktów rodzimych, zwłaszcza tych lokalnych ${ }^{25}$. Czy w tej sytuacji owe lokalne sklepy same z siebie wykazują się działaniami choćby zbliżonymi do patriotyzmu ${ }^{26}$.

20 T. Dziewulski, dz. cyt.

${ }^{21}$ D. Maison, T. Baran, Dobre, bo (nie)polskie? O uwarunkowaniach i konsekwencjach etnocentryzmu konsumenckiego, „Marketing i Rynek” 2014, nr 10, s. 3.

${ }^{22}$ T. Geodecki, B. Radziejewski, Kosmopolityzm kontra szowinizm, http://biznes.gazetaprawna.pl/artykuly/1011470,patrotyzm-gospodarczy-globalizacja.html [dostęp: 19.02.2020].

23 Ł. Skoczylas, dz. cyt., s. 223.

24 T. Dziewulski, dz. cyt.

25 Tamże.

${ }^{26}$ Patriotyzm gospodarczy..., dz. cyt. 


\section{Perspektywa producenta}

Warto spojrzeć na kwestie patriotyzmu gospodarczego z punktu widzenia podmiotów gospodarczych, polskich przedsiębiorców, prowadzących w Polsce - na małą i dużą skalę - swoją działalność gospodarczą. Polskie przedsiębiorstwa również skłaniają się ku działalności promującej patriotyzm ekonomiczny i wspieranie rodzimej produkcji, choć czynią to raczej z myślą o powodzeniu własnego biznesu, a nie interesie gospodarczym państwa ${ }^{27}$. Przekonanie, że patriotyzm gospodarczy to dobry, być może jedyny sposób na budowę silniejszej gospodarki, wcale nie jest powszechnie podzielane przez przedsiębiorców ${ }^{28}$.

W patriotyzmie gospodarczym chodzi wszak o to, by dbać o kondycję narodowej gospodarki, a najlepszą tego formą jest dbałość o wysoką jakość i wydajność pracy, o innowacyjność polskich przedsiębiorstw i produktów, co sprawi, że stają się one konkurencyjne na światowych rynkach ${ }^{29}$. Wielkie wezwania do patriotyzmu, do kupowania rodzimych wyrobów nic bowiem nie pomogą, a staną się wręcz szkodliwe, jeśli nasze rodzime towary będą marnej jakości; zaufanie do produktów danego kraju najlepiej buduje ich dobra jakość.

Przyjrzyjmy się temu problemowi z szerszej perspektywy, nie tylko wytwórczej - patriotyzm gospodarczy to przecież także świadome wykorzystywanie rodzimych technologii. Patriotyzm gospodarczy powinien sprowadzać się więc choćby do produkcji w Polsce innowacyjnych towarów o wysokiej jakości, które będą chcieli kupować sami Polacy. Takie produkty będą też pożądane na rynkach zagranicznych, stanowiąc najlepszą polską wizytówkę ${ }^{30}$.

Patriotyzm gospodarczy powinien oznaczać też m.in. (a może przede wszystkim) budowę silnych polskich firm i marek, godnych tego, by uznać, że „made in Poland” może oznaczać coś, z czego można i warto być dumnym ${ }^{31}$.

Przedsiębiorcy - jakże często - za gospodarczy patriotyzm uznają wspieranie ich rozwoju (na rynku krajowym i międzynarodowym) przez krajowe ustawodawstwo i aktywne działania $\mathrm{rządu}^{32}$. Z drugiej strony spora ich część podchodzi z wielkim dystansem do jakichkolwiek obowiązków wobec państwa i jego obywateli, zwłaszcza swych własnych pracowników.

Specyficznie rozumiany patriotyzm gospodarczy jest utożsamiany z protekcjonizmem. Jeśli jednak chcemy, by polskie produkty zdobywały zagraniczne rynki, jeśli - jak najbardziej słusznie - aspirujemy do tego, by polskie produkty były obecne na świecie, to nie możemy budować barier dla zagranicznych produktów w kraju. Musimy zaś dążyć

\footnotetext{
27 Tamże.

${ }_{28}$ G. Siemionczyk, Patriotyzm gospodarczy czy zwykty protekcjonizm, http://www.parkiet.com/artykul/1495234.html?print=tak [dostęp: 19.02.2020].

${ }^{29}$ E. Mączyńska-Ziemacka, T. Maćkowiak, dz. cyt.

${ }^{30}$ G. Siemionczyk, dz. cyt.

31 S. Ostrowski, dz. cyt.

32 A. Tycner, dz. cyt.
} 
do tego, by likwidować bariery poza granicami naszego kraju, a nie wznosić je u nas ${ }^{33}$. Nie chodzi więc o jakieś nadzwyczajne działania, tylko o naprawę pewnych dotychczasowych zaniechań. Musimy raczej koncentrować się na rozwiązaniach pozytywnych, być za czymś, a nie przeciwko czemuś.

Patriotyzm zatem może, a nawet powinien wyrażać się etosem pracy; ten etos przekładałby się zaś na wysoką jakość krajowej produkcji, a w efekcie jej atrakcyjność i konkurencyjność na świecie ${ }^{34}$. Za przejaw gospodarczego patriotyzmu należałoby uznać także zatrudnianie pracowników na godnych warunkach, nieuwłaczających poczuciu godności.

Warto zadać kolejne pytanie: Czego oczekują od rządu polscy przedsiębiorcy? Dobrze działający prywatny przedsiębiorca nie oczekuje (nie powinien oczekiwać) żadnej pomocy od państwa, bo budowanie biznesu na takich nadziejach czy założeniach byłoby nie tylko nieuczciwe, ale wręcz gospodarczo irracjonalne. Ważne jest co innego - stabilny, jasny i sprawiedliwy (cokolwiek to znaczy) system podatkowy i prawny.

Nowoczesny patriotyzm gospodarczy to również uczciwe płacenie podatków. Warto zatem postawić pytanie, gdzie polski przedsiębiorca - patriota, domagający się tego, by za wszelką cenę nabywać właśnie jego produkty i chronić jego działalność przed zagraniczną konkurencją, powinien je płacić. W Polsce czy może w innym kraju, w którym są mniejsze obciążenia podatkowe? To drugie wyjście wydaje się racjonalne z punktu widzenia biznesowego, tzw. optymalizacji podatkowej.

Jedną z najważniejszych powinności obywatela, zwłaszcza mieniącego się patriotą, tak producenta, jak i konsumenta, jest płacenie podatków i bezwzględne podporządkowanie się regułom, które obowiązują $\mathrm{w} \mathrm{kraju}^{35}$. Z całą pewnością zatem nie możemy nazwać patriotą kogoś, kto wprawdzie deklaruje, że kocha swoją ojczyznę, ale podatki woli płacić za granicą, na przykład w rajach podatkowych.

\section{Perspektywa państwa}

Choć pewne grupy polityczne i biznesowe próbują budować swoją pozycję polityczną i ekonomiczną na panicznym wręcz strachu przed kapitałem zagranicznym, zagranicznymi inwestycjami, to przecież jeśli zagraniczny inwestor jest poważny, daje gwarancję rozwoju przedsiębiorstwa i wykazuje skłonność, by podporządkować się naszym krajowym regułom gry, to jego działania wypadałoby uznać za korzystne.

Polska jest niestety krajem wciąż ubogim w kapitał, więc gdybyśmy mieli rozwijać się wyłącznie w oparciu o kapitał rodzimy, to byśmy się w ogóle nie rozwijali - my po prostu nie mamy dość kapitału i musimy go importować. Jednym z najważniejszych działań powinno być zatem powstrzymanie odpływu kapitałów za granicę przy założeniu, że w gospodarce kapitalistycznej to właśnie kapitał stanowi kluczowy czynnik rozwoju ${ }^{36}$.

33 G. Siemionczyk, dz. cyt.

34 Tamże.

35 A.K. Koźmiński, Między ekonomia a patriotyzmem, http://www.instytutobywatelski.pl/11278/lupa-instytutu/miedzy-ekonomia-a-patriotyzmem [dostęp: 19.02.2020].

36 T. Dziewulski, dz. cyt. 
Formą patriotyzmu gospodarczego będzie także zachęcanie zagranicznych przedsiębiorców do inwestowania w Polsce, do zatrudniania polskich pracowników, ale na godnych warunkach płacowych, a przy tym płacących podatki w Polsce ${ }^{37}$.

Patriotyzm gospodarczy to natomiast z całą pewnością wspieranie inwestycji i ekspansji polskich przedsiębiorstw w kraju i za granicą, tworzenie dobrego klimatu do inwestycji, rozwoju i konkurencji, wreszcie odbudowa polskiego przemysłu. Mądre wsparcie administracji publicznej dla biznesu może znakomicie przyspieszyć rozwój polskich przedsiębiorstw na rynkach międzynarodowych ${ }^{38}$. Wymaga to jednak zmiany postrzegania państwa i jego roli w gospodarce. Propagowane przez wiele lat hasło „kapitał nie ma ojczyzny" sprzyjało wyzbywaniu się - nieraz za bezcen - polskiego majątku narodowego $^{39}$, wypracowanego jeszcze w okresie PRL. Państwo miało pełnić jedynie rolę nocnego stróża, a pomysł ten traktowano całkiem serio.

Następstwem całkowicie błędnego przekonania, iż najlepszą polityką gospodarczą jest brak jakiejkolwiek polityki oraz redukowanie funkcji państwa do jak najszybszego zbudowania wolnorynkowej gospodarki i dostarczania - także w bardzo mocno ograniczonym stopniu - klasycznych dóbr publicznych, stały się recesja gospodarcza i destrukcja rynku pracy ${ }^{40}$.

Obecnie w naszym kraju są już oczywiście przedsiębiorstwa wytwarzające dobra nowoczesne o wysokiej jakości. Jednakże nadal żyjemy w błędnym przekonaniu, że „polskie” musi oznaczać ,gorsze”, i dlatego wiele produktów kupujemy za granicą - co w Polsce wcale nie dziwi.

Wciąż przecież państwo aktywne gospodarczo zachowuje swoją rolę w świecie, także w Europie. Jest tak do dzisiaj - i to również w tych krajach, gdzie głosi się (przeważnie na użytek zewnętrzny) teorie negujące rolę państwa, przede wszystkim w Stanach Zjednoczonych ${ }^{41}$ będących - wyłącznie deklaratywnie - ostoją leseferyzmu. Najlepiej jest to widoczne w Europie na przykładzie Niemiec, a w Azji - w Japonii. Oba te kraje poniosły w ostatniej wojnie światowej ogromną klęskę militarną, wygrały natomiast w okresie pokoju, kierując się głęboko i właściwie pojętym interesem państwowym czy narodowym. W krajach tych przez długie lata państwo bardzo aktywnie angażowało się w proces budowy silnej gospodarki narodowej ${ }^{42}$.

Współczesnymi liderami nowoczesnego patriotyzmu gospodarczego, rozgrywanego właśnie w płaszczyźnie ekonomicznej są jednak także Francja, Turcja, Indie, Chiny, Korea Południowa, Rosja oraz deklarująca liberalizm gospodarczy Wielka Brytania ${ }^{43}$.

37 T. Siemieniec, dz. cyt.

${ }_{38}$ K. Rybiński, Patriotyzm ekonomiczny, http://www.rp.pl/artykul/1017626-Patriotyzm-ekonomiczny. html [dostęp: 19.02.2020].

${ }_{39}$ M. Dębowska, J. Koziar, Patriotyzm gospodarczy, http://www.niedziela.pl/artykul/74126/nd/Patriotyzm-gospodarczy [dostęp: 19.02.2020].

${ }^{40}$ G. Siemionczyk, dz. cyt.

41 M. Dębowska, J. Koziar, dz. cyt.

42 S. Stodolak, ,Kupuj polskie”. Dlaczego patriotyzm gospodarczy jest pozbawiony sensu, https://biznes. gazetaprawna.pl/artykuly/1092244,patriotyzm-gospodarczy-w-polsce.html [dostęp: 19.02.2020].

43 L. Kostrzewski, P. Miączyński, Patriotyzm gospodarczy robi furore..., dz. cyt. 
Polska to jednak specyficzny kraj, który za drogę wzrostu gospodarczego w okresie tzw. transformacji systemowej wybrał pełne otwarcie się na kapitał międzynarodowy, choć najlepiej znane przykłady sukcesu gospodarczego w Europie, Azji i Ameryce opierają się raczej na drodze wiodącej w przeciwnym kierunku${ }^{44}$.

Na poziomie gospodarki narodowej pojawiają się coraz liczniejsze głosy wzywające do nasilenia protekcjonizmu, a nawet do podejmowania wrogich działań wobec innych państw i ich gospodarek - ma to być obrona produkcji krajowej przed zagraniczną konkurencją.

W warunkach globalizacji i liberalizacji rynków patriotyzm ekonomiczny nie może być uprawiany za pomocą standardowych taryfowych, parataryfowych i pozataryfowych narzędzi polityki handlowej, gdyż te są dekretowane przez porządek prawny UE i WTO oraz międzynarodowe konwencje, których sygnatariuszem jest Polska ${ }^{45}$. Dopuszczalny prawnie jest natomiast taki patriotyzm ekonomiczny, który wypiera z rodzimych rynków nieuczciwą konkurencję, nieuczciwe transfery zysków do rajów podatkowych i położonych poza granicami spółek-matek czy realizowany w ramach polityki prywatyzacyjnej.

Można go też uprawiać poprzez zamówienia publiczne - bez nich bowiem wiele fabryk nie powstałoby, a w czasach złej koniunktury nie mogłoby przetrwać ${ }^{46}$. Być może również w przetargach powinno się preferować podmioty krajowe, najlepiej lokalne ${ }^{47}$, ale polskie prawo stanowi, iż instytucje państwowe i samorządowe w procedurach przetargowych muszą kierować się przede wszystkim kryterium najniższej ceny.

Patriotyzmem gospodarczym jest więc bez wątpienia aktywne działanie państwa. Nie jest nim natomiast zawłaszczanie państwowych przedsiębiorstw, obsadzanie coraz liczniejszych, sztucznie tworzonych stanowisk przez reżimowych funkcjonariuszy bez odpowiednich kwalifikacji ani doświadczenia zawodowego, a zainteresowanych jedynie tym, by „drenować” bez żadnego umiaru ich finanse - w interesie własnym i swych mocodawców, ale nie w interesie państwa.

Interesy polityczne, zwłaszcza dzisiejszej biurokracji państwowej, choć wskazywane jako przejawy patriotyzmu, bardzo łatwo autonomizują się. Niestety, ich działania nie znajdują odzwierciedlenia w poprawie jakości życia ludności i zwiększaniu innowacyjności gospodarki jako podstawy długookresowej konkurencyjności - na rynku wewnętrznym i międzynarodowym.

Mamy przecież liczne organizacje międzynarodowe i ponadnarodowe, propagujące i promujące szeroko pojętą współpracę gospodarczą, mamy naszą wspólną Unię Europejską, która bez wielostronnej współpracy już dawno by się rozpadła, a zapewne w ogóle by nie powstała. Współpraca ekonomiczna z innymi państwami, nawet daleko posunięta, nie wyklucza jednak wsparcia, pomocy własnym przedsiębiorstwom zarówno w kraju, jak i przy podbijaniu zagranicznych rynków ${ }^{48}$. Pomoc ta może oczywiście przyjmować różne formy. Całkowitym zaprzeczeniem patriotyzmu jest zapewne polityczny i ekonomiczny

\footnotetext{
${ }^{44}$ Czym jest patriotyzm gospodarczy?, dz. cyt.

45 G. Siemionczyk, dz. cyt.

46 Tamże.

47 T. Dziewulski, dz. cyt.

48 L. Kostrzewski, P. Miączyński, Patriotyzm gospodarczy robi furore..., dz. cyt.
} 
serwilizm wobec naszego „największego”, a często ,jedynego” sojusznika i zawieranie transakcji gospodarczych bez należnej dbałości o nasz państwowy interes.

Gospodarki krajów unijnych, także tzw. starej piętnastki, a więc silniej zintegrowane politycznie i gospodarczo od „,nowych” państw członkowskich, od lat z wielkim powodzeniem opierają swój rozwój - co najmniej po części - na gospodarczym patriotyzmie, widocznym nie tylko wśród „zwykłych” konsumentów, ale i w sferze przedsięwzięć rządowych.

Nowoczesny patriotyzm ekonomiczny nie może być zatem zamykaniem się na współpracę z innymi krajami, nie może być zamykaniem granic przed obcą konkurencją, ale uczciwym i świadomym promowaniem polskich firm i marek produktów ${ }^{49}$.

W Polsce bez wątpienia musimy także przełamać wytworzoną w okresie transformacji systemowej barierę mentalną, gdy jakikolwiek styk polityki z biznesem już niejako z założenia źle się kojarzy ${ }^{50}$. Styk ten musi być jednak wolny od jakichkolwiek działań, noszących znamiona korupcji czy choćby korupcji politycznej.

Trudno bowiem o aktywną, prorozwojową politykę państwa, gdy istnieje w naszym kraju negatywny kapitał społeczny, uzdalniający do kooperacji jedynie na rzecz partykularnych celów grup poszukujących nienależnych korzyści. Przejawem negatywnego kapitału społecznego jest zwłaszcza upartyjnienie polityki, struktur administracji państwowej i samorządowej, a także gospodarki - analogicznie jak rozwój struktur mafijnych, źle rozumianej solidarności grup zawodowych, obyczajowych, światopoglądowych, etnicznych czy innych, zorientowanych niemal wyłącznie na swoje partykularne interesy ${ }^{51}$.

\section{Podsumowanie}

Dzisiejszy patriota gospodarczy, ów realny bądź tylko potencjalny ma prawo czuć się skonfundowany ${ }^{52}$, a wręcz zdezorientowany, przez różne, czasem absurdalne, odnoszenie się w życiu publicznym do jakichkolwiek założeń i celów patriotyzmu ekonomicznego. Promowanie dziś bowiem czy wręcz premiowanie polskich podmiotów tylko ze względu na narodowość ich właścicieli, acz z pominięciem rozlicznych, towarzyszących temu okoliczności, takich jak miejsce prowadzenia działalności i miejsce płacenia podatków, jak również ceny i jakość oferowanych produktów czy usług, wydaje się nie tylko dalece nieracjonalne, ale i nieuczciwe.

Oczywiście z punktu widzenia ekonomicznego patriotyzmu alternatywa w postaci kosmopolityzmu ekonomicznego, głoszącego, iż kapitał nie ma narodowości, brzmi co najmniej równie absurdalnie.

Niestety dziś to właśnie pomiędzy tymi, jakże odległymi od siebie biegunami postaw konsumentów i producentów oscyluje polska debata publiczna, szukająca - z braku intelektualnej podbudowy - najprostszych (i jednocześnie najgłupszych) rozwiązań. Zderza-

\footnotetext{
49 S. Ostrowski, dz. cyt.

50 T. Siemieniec, dz. cyt.

51 G. Siemionczyk, dz. cyt.

${ }^{52}$ T. Geodecki, B. Radziejewski, dz. cyt.
} 
jąc się z tak złożonymi realiami, zwolennicy obu skrajnych stanowisk tylko pogłębiają pojęciowe zamieszanie.

Z jednej strony mamy zatem zaprzysięgłych kosmopolitów, z maniakalnym wręcz uporem odmawiających kryterium narodowemu jakiegokolwiek znaczenia ekonomicznego. Prezentując taką postawę, zachowują się tak, jakby nigdy w dziejach urynkowienia polskiej gospodarki nie wydarzył się upadek polskich przedsiębiorstw, zwłaszcza ten $\mathrm{u}$ zarania transformacji systemowej, czy niedawny przecież i wciąż jeszcze pamiętany światowy kryzys finansowy i gospodarczy, ale też lawinowy wręcz wzrost przepływów finansowych z krajów gospodarczych peryferii, takich jak choćby Polska, do światowych centrów finansowych i gospodarczych.

Z drugiej strony coraz bardziej widoczni w publicznej debacie są ludzie przyznający się do patriotyzmu gospodarczego (deklarujący go), choć czasem poprzestający jedynie na pustych deklaracjach. W swoim, często naprawdę szlachetnym, chociaż z punktu widzenia współczesnej gospodarki naiwnym nastawieniu, nie mają oni odpowiedzi, ani choćby podpowiedzi, na podstawowe pytania o kwestie kluczowe: rezydencję podatkową, miejsce produkcji.

W ocenie gospodarki, jej efektywności i potencjału, należałoby brać pod uwagę wskaźniki szersze aniżeli tylko wartość dochodu czy produktu narodowego i jego dynamika - choć od tych mierników, co oczywiste, uciec nie można. Patriotyzm ekonomiczny powinien natomiast oznaczać dążenie do tego, aby gdy kraj rozwija się gospodarczo, całe społeczeństwo się bogaciło. Wyrazem ekonomicznego patriotyzmu było zatem na pewno, choć często dziś wyśmiewane, hasło wywodzące się jeszcze z lat 70. XX wieku: „Aby Polska rosła w siłę, a ludzie żyli dostatniej”, przy czym obecnie jego realizacja musi się dokonywać w warunkach pewnej równowagi, akceptowanych form społecznych i politycznych ${ }^{53}$. Patriotyzm ekonomiczny powinien bowiem zakładać, iż wszystkie grupy społeczne, chociaż zapewne w niejednakowym stopniu, uczestniczą w bogaceniu się, wobec czego nie tworzą się nadmierne, nieakceptowalne społecznie różnice dochodo$w^{54}$. Takie różnice są oczywiście niezbędne i normalne, ale sytuacje skrajne są nie tylko niewskazane, ale wręcz szkodliwe.

Podobnie rzecz się ma z życiem duchowym i intelektualnym społeczeństwa, które musi być odpowiednio wspierane, wspomagane przez potencjał ekonomiczny kraju i jego obywateli, ale nie może ono ograniczać się do zwykłej indoktrynacji. Dopełnieniem szeroko rozumianego, ,wielkiego” patriotyzmu gospodarczego, także w dobie globalizacji, jest właściwie pojmowany patriotyzm lokalny. Należy bowiem dbać także o swoją „małą ojczyznę", nawet w warunkach daleko posuniętej integracji europejskiej. Nie wolno jednakże przekroczyć granicy pomiędzy patriotyzmem gospodarczym a nacjonalizmem gospodarczym, który na dłuższą metę wcale nie przyczyni się do poprawy konkurencyjności polskiej gospodarki ${ }^{55}$.

\footnotetext{
53 A.K. Koźmiński, dz. cyt.

54 Tamże.

${ }_{55}$ G. Kołodko, Prof. Kołodko: Nacjonalizm gospodarczy nie przyczyni się do konkurencyjności polskiej gospodarki, https://biznes.gazetaprawna.pl/artykuly/1090859,prof-kolodko-nie-nalezy-popadac-w-nacjonalizmgospodarczy.html [dostęp: 19.02.2020].
} 


\section{Bibliografia}

Dębowska M., Koziar J., Patriotyzm gospodarczy, http://www.niedziela.pl/artykul/74126/nd/ Patriotyzm-gospodarczy [dostęp: 19.02.2020].

Dziewulski T., Patriotyzm ekonomiczny - czy to ma sens?, https://wspieramrozwoj.pl/artykul/82/patriotyzm-ekonomiczny-czy-ma-sens [dostęp: 19.02.2020].

Geodecki T., Radziejewski B., Kosmopolityzm kontra szowinizm, http://biznes.gazetaprawna. pl/artykuly/1011470,patrotyzm-gospodarczy-globalizacja.html [dostęp: 19.02.2020].

Kaszuba K., Patriotyzm przy sklepowej półce, „Wiadomości Handlowe” 2013, nr 9(128).

Kołodko G., Prof. Kołodko: Nacjonalizm gospodarczy nie przyczyni się do konkurencyjności polskiej gospodarki, https://biznes.gazetaprawna.pl/artykuly/1090859,prof-kolodko-nienalezy-popadac-w-nacjonalizm-gospodarczy.html [dostęp: 19.02.2020].

Kostrzewski L., Miączyński P., Patriotyzm gospodarczy: Czy powinniśmy kupować tylko to, co polskie?, http://wyborcza.pl/1,155287,13261428,Patriotyzm gospodarczy_Czy powinnismy kupowac tylko.html [dostęp: 19.02.2020].

Kostrzewski L., Miączyński P., Patriotyzm gospodarczy robi furorę w mediach. Będa zmiany w prawie, http://wyborcza.biz/biznes/1,147584,19980984,patriotyzm-gospodarczy-robi-furore-w-mediach-beda-zmiany-w.html [dostęp: 19.02.2020].

Kowalczyk J., Co oznacza „patriotyzm gospodarczy” dla Polaków, https://www.pb.pl/co-oznacza-patriotyzm-gospodarczy-dla-polakow-868098 [dostęp: 19.02.2020].

Koźmiński A.K., Między ekonomiq a patriotyzmem, http://www.instytutobywatelski.pl/11278/ lupa-instytutu/miedzy-ekonomia-a-patriotyzmem [dostęp: 19.02.2020].

Maison D., Baran T., Dobre, bo (nie)polskie? O uwarunkowaniach i konsekwencjach etnocentryzmu konsumenckiego, „Marketing i Rynek” 2014, nr 10.

Mączyńska-Ziemacka E., Maćkowiak T., Dobre, bo polskie, http://miesiecznik.wdrodze.pl/ index.php?mod=archiwumtekst\&id=16198\#.XoloynLgrIV [dostęp: 19.02.2020].

Ostrowski S., Patriotyzm ekonomiczny to nie jest kupowanie produktu tylko dlatego, że jest polski, https://biznesnaostro.pl/patriotyzm-ekonomiczny-to-nie-jest-kupowanie-produktutylko-dlatego-ze-jest-polski/ [dostęp: 19.02.2020].

Patriotyzm gospodarczy a decyzje zakupowe Polaków, https://biznes.newseria.pl/komunikaty/ patriotyzm-gospodarczy-a,b2026028150 [dostęp: 19.02.2020].

Rybiński K., Patriotyzm ekonomiczny, http://www.rp.pl/artykul/1017626-Patriotyzm-ekonomiczny.html [dostęp: 19.02.2020].

Siemieniec T., Patriotyzm gospodarczy Beaty Szydto (wywiad), https://www.pb.pl/patriotyzm-gospodarczy-beaty-szydlo-wywiad-830401 [dostęp: 19.02.2020].

Siemionczyk G., Patriotyzm gospodarczy czy zwykty protekcjonizm, http://www.parkiet.com/ artykul/1495234.html?print=tak [dostęp: 19.02.2020].

Skoczylas Ł., Patriotyzm konsumencki: próba spojrzenia socjologicznego, „Ruch Prawniczy, Ekonomiczny i Socjologiczny" 2013, z. 4.

Stodolak S., „Kupuj polskie”. Dlaczego patriotyzm gospodarczy jest pozbawiony sensu, https://biznes.gazetaprawna.pl/artykuly/1092244,patriotyzm-gospodarczy-w-polsce.html [dostęp: 19.02.2020]. 
Tycner A., Patriotyzm gospodarczy nie równa się walce z zagranicznym kapitałem, http://finanse.wnp.pl/patriotyzm-gospodarczy-nie-rowna-sie-walce-z-zagranicznymkapitalem, 273028 1 0 0.html [dostęp: 19.02.2020].

Włodarczyk K., Globalizacja a patriotyzm ekonomiczny polskich konsumentów, „Studia Ekonomiczne. Zeszyty Naukowe Uniwersytetu Ekonomicznego w Katowicach”2015, nr 214.

Zielazna J., Nasza ekonomia to drogi i bezdroża, wywiad z prof. Elżbietą Mączyńską, https:// plus.pomorska.pl/nasza-ekonomia-to-drogi-i-bezdroza/ar/9957512 [dostęp: 10.03.2020].

\section{Streszczenie \\ Patriotyzm ekonomiczny - droga do wzmocnienia gospodarki czy droga donikąd?}

W polskim społeczeństwie, po okresie fascynacji zagranicą, odradzają się postawy patriotyczne. Patriotyzm ten przybiera różne formy, a jedną z nich staje się patriotyzm gospodarczy. Często sprowadza się go wyłącznie do etnocentryzmu konsumenckiego, ale musi on zyskać szerszy wymiar. Powinien dotyczyć postaw reprezentowanych nie tylko przez konsumentów, ale również przez przedsiębiorców. Nie może jednak przybierać postaci ekonomicznego szowinizmu.

Słowa kluczowe: nacjonalizm, szowinizm, patriotyzm, patriotyzm ekonomiczny

\section{Summary \\ Economic patriotism - the road to strengthen the economy or the road nowhere?}

In Polish society, after a period of fascination with 'abroad', patriotic attitudes are being revived. This 'patriotism' takes different forms, including the form of economic patriotism. It is often reduced to consumer ethnocentrism, but it also has a wider dimension. It should concern the attitudes of consumers and entrepreneurs. It cannot, however, take the form of economic chauvinism.

Keywords: nationalism, chauvinism, patriotism, economic patriotism 
Weronika Wojtanowska weronikamw@vp.p1 https://orcid.org/0000-0003-3727-0517

Uniwersytet Papieski Jana Pawła II w Krakowie

\section{O możliwości zastosowania Nagelowskiej typologii racji do działania we współczesnej etyce cnót}

\section{Wstęp}

Celem artykułu jest przedstawienie możliwości powiązania współczesnej, neoarystotelesowskiej etyki cnót z problematyką dotyczącą typologii racji do działania ${ }^{1}$. Pozwoliłoby to w większym stopniu zbliżyć ją do modelu niedyrektywnego, dzięki czemu zmniejszyłaby się adekwatność obiekcji, które są wysuwane wobec etyki cnót przez jej przeciwników. Jednocześnie zaproponowane ujęcie mogłoby w pewnym stopniu przyczynić się do udoskonalenia współczesnej etyki cnót oraz wzmocnienia jej zdolności do stawiania czoła wyzwaniom i problemom współczesnego świata.

Ze względu na ograniczone ramy artykułu głównym punktem odniesienia w części polemicznej będą rozważania Nataszy Szutty mające na celu odparcie zarzutów wobec etyki cnót oraz jej argumentacja dotycząca przewagi edukacji moralnej opartej na kategorii cnoty nad modelem niedyrektywnym. W pozytywnej części artykułu nawiążę do współczesnych koncepcji próbujących połączyć etykę cnót z filozofią moralną opartą na pojęciu racji. Podejmę próbę wykazania, że typologia racji do działania, która została zaproponowana przez Thomasa Nagela, może zostać powiązana z praktycznym wymiarem kształtowania cnót w procesie wychowania, co z kolei może przyczynić się do większego zbliżenia etyki cnót do modelu niedyrektywnego.

\footnotetext{
${ }^{1}$ Artykuł powstał w ramach projektu badawczego nr 2016/23/N/HS1/00641, finansowanego przez Narodowe Centrum Nauki.
} 


\section{Problemy współczesnej etyki cnót}

Neoarystotelesowska etyka cnót zyskuje coraz większą popularność i znaczenie, również na gruncie filozofii polskiej². Jednocześnie, wraz ze wzrostem zainteresowania rośnie liczba publikacji krytycznych wobec tego nurtu. Zarzuty wysuwane są ze strony różnorodnych stanowisk i dotyczą różnych poziomów refleksji. Na podstawie badań eksperymentalnych poddaje się w wątpliwość nie tylko możliwość kształtowania, ale nawet samo istnienie tak fundamentalnych kategorii, jak charakter i cnota w ich tradycyjnym rozumieniu. Krytyka etyki cnót ma miejsce również na płaszczyźnie etycznej i zarazem praktycznej, ponieważ analiza psychologicznych mechanizmów związanych z procesem wychowania i edukacji moralnej może prowadzić do prób podważenia godziwości i akceptowalności metod, którymi posługują się wychowawcy zajmujący się praktycznym wdrażaniem cnót.

Zarzuty pierwszego typu, dotyczące efektywności etyki cnót, wysuwane są przede wszystkim ze strony sytuacjonistów, którzy zaprzeczają istnieniu elementów niezbędnych do tego, aby można było zasadnie mówić o istnieniu charakteru. Istotą argumentacji jest powoływanie się na wyniki badań empirycznych, które wykazują, że na podejmowane decyzje przemożny wpływ mają czynniki sytuacyjne, zarówno o charakterze zewnętrznym, jak i wewnętrznym. W związku z tym w wątpliwość poddawana jest efektywność działań mających na celu udoskonalenie charakteru człowieka, jako że jego decyzje zdają się wynikać w znacznej mierze z zestawu przypadkowych okoliczności ${ }^{3}$. Sytuacjoniści zwrócili uwagę na problematyczność podstawowych założeń przyjmowanych w etyce cnót, jednak ich wnioski wydają się zbyt daleko idące. W literaturze naukowej wskazuje się na to, że środowisko - w tym również wychowanie - ma istotny wpływ na kształtowanie się określonych postaw, motywacji i dyspozycji do działania ${ }^{4}$.

${ }^{2}$ Zob. np. J. Jaśtal (red.), Etyka i charakter, Wydawnictwo Aureus, Kraków 2004; J. Jaśtal, Natura cnoty. Problematyka cnoty w neoarystotelesowskiej etyce cnót, Księgarnia Akademicka, Kraków 2009; N. Szutta, Wspótczesna etyka cnót: projekt nowej etyki?, Wydawnictwo Uniwersytetu Gdańskiego, Gdańsk 2008; N. Szutta, Dyskusja z sytuacjonistyczna krytyka etyki cnót: odpowiedź na zarzuty Gilberta Harmana, „Diametros” 2012, nr 31, s. 88-112; N. Szutta, A. Szutta (red.), W poszukiwaniu moralnego charakteru, Wydawnictwo Academicon, Lublin 2015; N. Szutta, Wychowanie moralne z perspektywy etyki cnót, „Diametros” 2015, nr 46, s. 111-133; N. Szutta, Czy istnieje coś, co zwiemy moralnym charakterem i cnota? Dyskusja z sytuacjonistyczna krytyka etyki cnót, Wydawnictwo Academicon, Lublin 2017. Etyka cnót w ujęciu neoarystotelesowskim nie jest jedyną odmianą etyki cnót, która ma znaczenie we współczesnej myśli etycznej, jednak to ten nurt jest najbardziej popularny, zwłaszcza w filozofii anglosaskiej. Najbardziej znana definicja cnoty, do której nawiązują współcześni kontynuatorzy myśli Arystotelesa, brzmi następująco: „A więc dzielność etyczna jest trwałą dyspozycją do pewnego rodzaju postanowień, polegającą na zachowywaniu właściwej ze względu na nas średniej miary, którą określa rozum, i to w sposób, w jaki by ją określił człowiek rozsądny". Arystoteles, Etyka Nikomachejska, PWN, Warszawa 2012, s. 1107a.

${ }^{3}$ Zob. np. J. Doris, Lack of character. Personality and moral behavior, Cambridge University Press, Cambridge 2002; G. Harman, Moral philosophy meets moral psychology: virtue ethics and the fundamental attribution error, "Proceedings of the Aristotelian Society" 1999, No. 109, s. 316-331; D. Kahneman, Pułapki myślenia. O myśleniu szybkim i wolnym, Media Rodzina, Poznań 2012.

${ }^{4}$ Zob. np. N. Szutta, Dyskusja ..., dz. cyt.; N. Szutta, A. Szutta (red.), W poszukiwaniu ..., dz. cyt.; M. Cohut, Nature vs. nurture: Do genes influence our morals?, "Medical News Today", 27 Feb. 2019, https://www. medicalnewstoday.com/articles/324561.php [dostęp: 6.03.2019]. 
Drugi wymiar krytyki może polegać na postawieniu pytania, czy metody zalecane przez teoretyków etyki cnót i stosowane przez wychowawców zajmujących się praktycznym kształtowaniem cnót nie dyskredytują etyki cnót pod względem moralnym. W niniejszym artykule pominiemy zagadnienia, które nie są w specyficzny sposób związane z etyką cnót, a jedynie znajdują w niej swoje odzwierciedlenie - takie jak problem odpowiedzialności, trafu moralnego lub wolnej woli. Skupimy się na problemach, które w szczególny sposób związane są z praktyką wychowania, a zatem dotyczą praktycznego kształtowania cnót ${ }^{5}$. Do takich problematycznych kwestii należy między innymi wykorzystywanie kategorii wstydu i winy jako regulatorów zachowania wychowanków ${ }^{6}$, korzystanie $z$ technik behawioralnych, a także mechanizm wdrukowania i bezbronność wychowanka wobec autorytetu.

Zależność i bezbronność dziecka wobec autorytetu i mechanizm wdrukowania zdają się budzić największe wątpliwości pod względem moralnym, dlatego skupimy się właśnie na tych problemach. Powszechne istnienie wyżej wymienionych zjawisk, które są ściśle związane z początkowym etapem kształtowania charakteru, dostarcza argumentów na rzecz tezy, że nie ma ostrej linii oddzielającej proces wychowania od indoktrynacji. Problem ten w zwięzły i satyryczny sposób podsumowuje Carl Sagan: „Młode zwierzęta obdarzone są niemal ejdetyczną pamięcią, lecz pozbawione są wszelkich zdolności do krytycznej oceny. Wierzą we wszystko, czego się ich uczy. Jak pokazuje przykład kacząt paradujących z uwielbieniem w ślad za brodatym etologiem, wdrukowanie może prowadzić do nadużyć ze strony pozbawionych skrupułów wyższych zwierząt. Młode z ochotą uczą się, kogo należy kochać, a kogo nienawidzić"7. W dużo bardziej obszerny sposób zagadnienie to zostało omówione przez Denise Winn, która w nawiązaniu do prac Hansa Tocha zauważa ${ }^{8}$, że ,,indoktrynacja, czy jest zamierzona, czy nie, zachodzi w dzieciństwie"9. Winn przypomina o istnieniu czynników, które sprawiają, że dziecko w dużym stopniu narażone jest na indoktrynację i powiązany z nią mechanizm wdrukowania ${ }^{10}$. Pierwszym $\mathrm{z}$ nich jest ograniczona umiejętność percepcji: świat dziecka to przestrzeń, w której centralną rolę pełnią rodzice - „dziecko zaczyna wierzyć w pewne rzeczy, dlatego że nie zna niczego innego" ${ }^{11}$. Drugi czynnik to zależność od opiekunów

5 Omawiane tu zagadnienia są przedstawione w szerszym kontekście w książce: W. Wojtanowska, Filozofia moralna Thomasa Nagela a wspótczesna etyka cnót, Wydawnictwo Naukowe Uniwersytetu Papieskiego Jana Pawła II w Krakowie, Kraków 2019.

${ }^{6}$ Emocja wstydu nie jest w szczególny sposób powiązana z neoarystotelesowską etyką cnót. Należy ją raczej traktować jako często występujący element technik wychowawczych mających na celu kształtowanie charakteru. Sam Arystoteles uznawał znaczenie tej emocji, podkreślając, że jest ona wymagana głównie w okresie młodości. Zob. Arystoteles, dz. cyt., s. 1128b. Zob. też J. Górska, Wstyd jako emocja wywoływana społecznie, „Societas/Communitas” 2012, nr 2(14), s. 179, 184; A. Heller, Power of shame. A rational perspective, Routledge, London 1985, s. 5; B. Williams, Shame and necessity, University of California Press, Berkeley 1993.

7 C. Sagan, A. Druyan, Cienie zapomnianych przodków. W poszukiwaniu naszej tożsamości, Zysk i S-ka, Poznań 2000, s. 189.

${ }^{8}$ H. Toch, The social psychology of social movements, Methuen, London 1966.

9 D. Winn, Manipulowanie umystem: pranie mózgu, warunkowanie, indoktrynacja, Wydawnictwo Unus, Wałbrzych 2003, s. 59.

10 Tamże, s. 64.

11 Tamże, s. 64. 
i wcześnie nabyta wiedza o tym, że opłaca się dostosowywać do oczekiwań. Trzecim problemem jest ograniczenie informacyjne i utrudniona weryfikowalność informacji we wczesnym okresie życia dziecka, a czwarty element to naturalna potrzeba wzorowania się na ojcu lub matce. Wymienione powyżej punkty współtworzące mechanizm wdrukowania wzmacniają późniejszą gotowość percepcyjną na określone bodźce: „Proces ten ma swoje źródło w fizjologii. Gdybyśmy mieli reagować na każdy bodziec w naszym otoczeniu, nasz system nerwowy byłby przeładowany i załamałby się. Musimy zatem stosować selekcję" $"$. Nieświadoma gotowość percepcyjna na bodźce, które do nas docierają, ma istotne znaczenie w deformowaniu obrazu poszczególnych elementów rzeczywistości, co z kolei ma nieuświadomiony wpływ na formułowane oceny etyczne określonych zjawisk. Obecność tych mechanizmów świadczy o tym, że wychowanie polegające na kształtowaniu cnót obejmuje również elementy typowe dla procesów indoktrynacji. Może to być argumentem na korzyść tezy, że wato jest podjąć wysiłki w celu położenia akcentów na inne elementy służące do budowania ludzkiej moralności i doskonalenia ludzkich charakterów, co może przyczynić się do udoskonalenia samej etyki cnót pod względem etycznym. Często bowiem nie zdajemy sobie sprawy z wpływu powyższych mechanizmów na posiadane przekonania i cechy charakteru. Uświadomienie sobie oraz innym tych zjawisk stanowi niezbędną podstawę do tego, aby chociaż w pewnym stopniu można było im przeciwdziałać ${ }^{13}$. Chociaż bowiem etyka cnót nie jest w stanie zlikwidować powyższego problemu, to wydaje się, że istnieje możliwość jego złagodzenia.

\section{Etyka cnót a niedyrektywny model wychowania}

W obecnych czasach takie rozumienie cnót, które kładzie nacisk na ich kognitywny aspekt, wydaje się szczególnie istotne między innymi dlatego, że wraz z rozwojem technologii zwiększają się techniczne możliwości przeprowadzania różnego typu manipulacji w rozmaitych sferach życia społecznego ${ }^{14}$. Ze względu na współczesne możliwości manipulacji ludzkim umysłem zarówno w wymiarze indywidualnym, jak i zbiorowym przed etyką cnót pojawia się dodatkowe pytanie o to, jakie są skuteczne sposoby obrony przed tymi działaniami. Od tradycyjnych i behawioralnych sposobów wdrażania cnót, w dużym stopniu bazujących na elementach bezkrytycznego zaufania do autorytetu, bardziej obiecujące wydaje się współczesne, kognitywno-afektywne ujęcie cnoty, rozwijane na gruncie filozofii polskiej na przykład przez Nataszę Szuttę. Nie jest ono jednak wolne od trudności, co postaramy się wykazać w dalszej części artykułu.

Rozwijając neoarystotelesowską etykę cnót, N. Szutta często odwołuje się do myśli Stagiryty. Dla samego Arystotelesa charakterystyczne było z jednej strony podkreślanie

12 Tamże, s. 65.

13 Por tamże, s. 66.

14 Zob. np. R.L. Sandler (red.), Ethics and emerging technologies, Palgrave Macmillan, Boston 2014, s. 13 i nast.; L. Winner, Technologies as forms of life, [w:] R.L. Sandler (red.), Ethics and emerging technologies, Palgrave Macmillan, Boston 2014, s. 51, 53; W. Glannon, Psychofarmacology and functional neurosurgery: manipulating memory, thought and mood, [w:] R.L. Sandler (red.), Ethics and emerging technologies, Palgrave Macmillan, Boston 2014, s. 167-179. 
roli rozumu w kształtowaniu cnót, a z drugiej strony silny nacisk na to, że początek edukacji moralnej opiera się przede wszystkim na zaufaniu do autorytetu wychowawcy, posłuszeństwie i dyscyplinie ${ }^{15}$. Broniąc etyki cnót, N. Szutta argumentuje, że behawioralne rozumienie cnoty, polegające na utrwalaniu prostych i bezrefleksyjnych nawyków, stanowi jedynie początek edukacji moralnej we wczesnym okresie rozwoju wychowanka ${ }^{16}$. Stopniowo jest ono uzupełniane o elementy afektywne, które pełnią istotną rolę w układzie motywacyjnym podmiotu, oraz kognitywne, polegające na uświadamianiu złożoności problematyki moralnej, uczeniu roztropności i ostrożności w ocenach moralnych. Dlatego jeden z głównych zarzutów - utożsamiający wdrażanie cnoty z indoktrynacją - jest według niej nieadekwatny ${ }^{17}$. Ponadto $\mathrm{w}$ swojej polemice $\mathrm{z}$ niedyrektywnymi metodami wychowania moralnego przedstawia argumenty mające na celu wykazanie, że przeciwko niedyrektywnym metodom wychowawczym można w zasadzie wysunąć podobne obiekcje, jak wobec etyki cnót ${ }^{18}$.

Trudno nie zgodzić się z tezą, że zarzut indoktrynacji jest w dużym stopniu osłabiony w przypadku afektywno-kognitywnego rozumienia cnoty. Jednak wydaje się, że zbyt uproszczone byłoby stwierdzenie, że w takim ujęciu w ogóle nie ma on zastosowania. Chociaż elementy habituacji są w późniejszym okresie życia dziecka uzupełniane o aspekty kognitywne i afektywne, to jednak w początkowym okresie wyuczanie prostych schematów behawioralnych jest podstawą edukacji moralnej ${ }^{19}$. Przede wszystkim rodzi to problemy związane ze wspomnianym powyżej zjawiskiem wdrukowania. Warto również zauważyć, że w modelu kognitywno-afektywnym pierwotne metody, stosowane w początkowych latach życia dziecka, w późniejszym okresie nie zostają całkowicie wyeliminowane. Gdyby tak było, mielibyśmy bowiem do czynienia z sytuacją, gdy behawioralne rozumienie cnoty przechodzi stopniowo w model niedyrektywny - jednak nie na tym polega ujęcie afektywno-kognitywne. Nadal bowiem kluczową rolę pełni utrwalanie dyspozycji oraz zaufanie do autorytetu ${ }^{20}$.

N. Szutta podkreśla, że edukacja moralna powinna zaczynać się od prostego modelu behawioralnego i dopiero z czasem ,miejsce nawyków powinny zająć właściwie rozumiane cnoty. Dziecko, stawiając różne pytania i poszukując najlepszych odpowiedzi,

\footnotetext{
15 Arystoteles, dz. cyt., s. 1118 b.

16 Por. „Trudno oczywiście wyobrazić sobie wychowanie moralne w duchu właściwie rozumianych cnót na poziomie wczesnej edukacji. W tym okresie znacznie ważniejsze jest wypracowanie pewnych nawyków, które następnie mogą być rozwinięte w kognitywno-afektywnie rozumiane cnoty etyczne, gdy dziecko osiągnie wyższy stopień dojrzałości intelektualnej i emocjonalnej. Behawioralnie rozumiane cnoty mogą stanowić początek wdrażania dziecka w podejmowanie moralnych decyzji”. N. Szutta, Wychowanie moralne..., dz. cyt., s. 118.

17 Tamże, s. 117, 123-128. Indoktrynacja jest przez N. Szuttę zdefiniowana jako „świadome i systematyczne wpajanie komuś «jedynie słusznych» przekonań, bez jakiegokolwiek uzasadniania, metodami nieracjonalnymi, wykorzystując proste i nieświadome warunkowanie zachowania. Indoktrynacja nie dopuszcza krytyki i kwestionowania propagowanych wartości”. Tamże, s. 123. Zasadniczo przyjmuję w tym artykule definicję indoktrynacji zaproponowaną przez N. Szuttę, z zastrzeżeniem, iż wydaje się, że niesłuszne jest włączenie do definicji indoktrynacji sformułowania „,bez jakiegokolwiek uzasadniania”, ponieważ nawet najbardziej totalitarne reżimy, indoktrynując ludzi, zazwyczaj podawały jakieś uzasadnienie - często była nim określona ideologia lub religia.

${ }_{18}$ Tamże, s. 123-127.

19 Tamże, s. 118, 120.

${ }^{20}$ Zob. np. tamże, s. 116.
} 
powinno stopniowo przestać postępować automatycznie według ustalonych wcześniej schematów"21. Pojawia się tu jednak zasygnalizowany powyżej problem. Można bowiem postawić pytanie, w jaki sposób ludzie mają być zdolni do krytycznej (ale mądrze krytycznej) oceny wcześniej przekazywanych im poglądów i do dostrzegania złożoności problematyki moralnej, jeśli w okresie dzieciństwa - czyli wtedy, gdy ich psychika jest najbardziej podatna na procesy wdrukowania i utrwalenie się określonych dyspozycji są wychowywani do automatycznych reakcji i całkowitego zaufania do autorytetu. Jeśli krytyczne myślenie nie jest wspierane w okresie wczesnego dzieciństwa, czyli wówczas, gdy tworzą się podstawowe dyspozycje moralne i intelektualne, to czy później nie jest już za późno na to, aby w optymalny sposób wykształciła się umiejętność sprawnego myślenia i oszacowywania przekazywanych zasad i wytycznych? Czy rzeczywiście w późniejszym wieku możliwe jest (chodzi tu o powszechną praktykę, a nie działanie jednostek o wyjątkowych cechach) skuteczne rezygnowanie z wcześniej wdrożonych i utartych schematów, upraszczających złożoność problematyki moralnej?

Zatem można stwierdzić, że ujęcie to nie jest wolne od wewnętrznych trudności, pojawiają się tu bowiem trudne kwestie dotyczące omówionego powyżej mechanizmu wdrukowania: elementy kognitywno-afektywne wprowadzane są już po tym, jak umysł wychowanka został w znacznym stopniu pozbawiony umiejętności dystansowania się do przekazywanych treści i rozpoznawania dokonywanej indoktrynacji lub manipulacji. Można więc postawić pytanie o to, czy późniejszy proces zastępowania prostych nawyków refleksyjnością i wielostronnym spojrzeniem ma szanse odbywać się w sposób skuteczny i czy w praktyce wychowania proces ten odbywa się w sposób optymalny.

Przedstawiona powyżej teza dotycząca zacierania się różnicy pomiędzy tradycyjnym wychowaniem i indoktrynacją może zostać uznana za kontrowersyjną lub zbyt mocną i z pewnością można z nią dyskutować, jednak wydaje się, że nie należy ignorować wyżej wymienionych mechanizmów i problemów lub stwierdzać a priori, że nie ma możliwości ich złagodzenia ani częściowego rozwiązania. Zanim jednak podejmiemy próbę złagodzenia tego dylematu poprzez zbliżenie etyki cnót do modelu niedyrektywnego, należy zadać pytanie, czy faktycznie może to przynieść jakąś korzyść pod względem etycznym. Pytanie to jest zasadne między innymi dlatego, że N. Szutta argumentuje, iż metody niedyrektywne przynajmniej w jakimś stopniu narażone są na podobne zarzuty, co etyka cnót.

N. Szutta w trafny sposób ujmuje istotę metod niedyrektywnych, pisząc, że „,w niedyrektywnych koncepcjach celem edukacji moralnej jest ukształtowanie intelektualnych procesów, które pozwalają wychowankom samodzielnie dochodzić do moralnych przekonań, doskonalić techniki moralnego rozumowania i selekcjonowania wartości"22. W związku z tym zauważa ona, iż nawet w ujęciach niedyrektywnych występują pewne założenia na temat przewagi określonych wartości moralnych, takich jak otwartość, tolerancja, krytycyzm i zaufanie do własnego rozumu. Założenia te w modelu niedyrektywnym mają charakter ukierunkowujący praktyki moralne - nie jest to zatem taki model wychowania, który w żaden sposób nie steruje poglądami i zachowaniem wychowanka. Można jednak kontrargumen-

21 Tamże, s. 120.

22 Tamże, s. 122. 
tować, że jedną z podstawowych cech indoktrynacji jest wdrażanie do bezkrytycznego przyjmowania poglądów swoich wychowawców, a wymienione przez N. Szuttę wartości, które promowane są w ujęciu niedyrektywnym, stanowią zaprzeczenie takiego podejścia. Chociaż pod względem formalnym można uznać, że również w modelu niedyrektywnym mamy do czynienia z pewnym śladem indoktrynacji, to jednak zarzut indoktrynacji jest znacznie bardziej adekwatny w etyce cnót ze względu na to, że istotną rolę pełnią w niej zaufanie do autorytetu i habituacja wdrażana od pierwszych lat życia wychowanka.

Zatem wydaje się, że jednym ze sposobów łagodzenia omawianego konfliktu moralnego wewnątrz etyki cnót może być postulat jak najwcześniejszego zbliżenia jej do modelu niedyrektywnego, co mogłoby zostać częściowo zrealizowane między innymi poprzez wzrost znaczenia tych cnót, które w szczególny sposób łączą w sobie wymiar etyczny i intelektualny. Poniżej podejmę próbę wykazania, że etyka oparta na pojęciu racji może zostać włączona do rozważań w ramach etyki cnót i może stanowić jeden z elementów służących do nadania jej mniej dyrektywnego charakteru. Ze względu na ramy artykułu skupię się na rozważeniu przydatności typologii racji zaproponowanej przez Thomasa Nagela. Może mieć ona zastosowanie we współczesnej etyce cnót na dwóch płaszczyznach. Po pierwsze, dyspozycja do ważenia racji różnego typu spełnia wymogi umożliwiające potraktowanie jej jako jednej z cnót, związanej ze zdolnością do trafnego osądu moralnego i z doskonaleniem rozumowania praktycznego. Dyspozycja taka wzbogaca katalog cnót o cenny element i może być jednym ze sposobów realizacji postulatu zbliżania tego nurtu do modelu niedyrektywnego. Oprócz tego zasygnalizuję, że zastosowanie Nagelowskiej typologii racji w etyce cnót może mieć szerszy wymiar, ponieważ może wiązać się z ograniczeniem przytoczonych powyżej wątpliwych metod kształtowania charakteru.

\section{Nagelowska typologia racji do działania a neoarystotelesowska etyka cnót}

We współczesnej myśli etycznej pojawiają się koncepcje, które rozwijają neoarystotelesowskie ujęcie cnót, a jednocześnie podkreślają znaczenie zdolności do prawidłowego rozpoznawania racji moralnych. Samo pojęcie racji praktycznych jest złożone i na jego temat powstała obszerna literatura ${ }^{23}$. Aby nie odchodzić od meritum omawianego problemu, w tym artykule przyjmujemy najbardziej ogólną definicję, mówiącą, że racje to „wszystkie czynniki i okoliczności” ${ }^{24}$, które należy wziąć pod uwagę przy podejmowaniu decyzji. W propozycjach etycznych opartych na pojęciu racji kładzie się nacisk na ko-

${ }^{23}$ Zob. np. M. Rutkowski, Dlaczego potrafimy działać moralnie?, Wydawnictwo Naukowe Scholar, Warszawa 2010; T. Żuradzki, Internalizm i eksternalizm w metaetyce, Wydawnictwo Uniwersytetu Jagiellońskiego, Kraków 2012; M. Pyka, Działanie, moralność, podmiotowość: wokół myśli Thomasa Nagela, Wydawnictwo Księgarnia Akademicka, Kraków 2016. Zob. też J. Lenman, Reasons for Action: Justification, Motivation, Explanation, https://plato.stanford.edu/entries/reasons-just-vs-expl/ [dostęp: 4.09.2019].

${ }^{24}$ M. Pyka, dz. cyt., s. 21. Mówiąc ściślej, wszystkie brane pod uwagę czynniki to racje prima facie. W drugim znaczeniu racja do określonego działania dotyczy już podjętej decyzji, w której stwierdzamy, że w danej sytuacji mamy rację, aby coś zrobić i (być może) decydujemy się na to działanie. 
gnitywny aspekt decyzji moralnych i zdolność do rozumowania praktycznego - zatem powiązanie etyki cnót z koncepcjami tego typu w specyficzny sposób zbliża ją do modelu niedyrektywnego. Przykładami takich rozwiązań mogą być koncepcje Johna McDowella, Roberta Audiego, Bernarda Williamsa lub Marthy Nussbaum.

W niniejszym artykule proponujemy zwrócenie uwagi na filozofię moralną Thomasa Nagela, ponieważ wydaje się, że powiązanie jej z etyką cnót otwiera interesujące perspektywy badawcze. Chociaż Nagel nie rozwija swojej propozycji w kierunku etyki cnót, w literaturze wtórnej zwrócono uwagę na to, że podjęcie takiej próby jest możliwe lub nawet wskazane ${ }^{25}$. Nieredukcjonistyczne podejście Nagela znane i wpływowe jest przede wszystkim w filozofii umysłu, jednak ma ono zastosowanie również w teorii etycznej. Dostrzeżenie faktu, że w ludzkiej podmiotowości współistnieją dwie perspektywy (internal and external standpoint) pozwala odnaleźć uniwersalne podłoże wspólne wszystkim ludziom, a jednocześnie dopuszcza pewną elastyczność i uwzględnia pluralizm wartości i racji ${ }^{26}$. Powiązanie racji moralnych ze współwystępowaniem oraz nieredukowalnością i równoprawnością wewnętrznego i zewnętrznego punktu widzenia ma znaczący wpływ na jego propozycje z zakresu etyki, ponieważ współistnienie dwóch perspektyw stanowi uzasadnienie występowania i wzajemnego równoważenia się różnych typów wartości i racji. Jeśli wewnętrzna i zewnętrzna perspektywa są równie realne, równie niezastępowalne i konieczne w swoim współistnieniu, to oznacza również prawomocność różnego typu racji - tych związanych z wewnętrzną, jak i zewnętrzną perspektywą. Poniżej w skrótowy sposób przypomnimy typologię racji zaproponowaną przez Thomasa Nagela, a następnie pokażemy, w jaki sposób to zagadnienie można powiązać z etyką cnót.

Perspektywę zewnętrzną podmiotu wyrażają racje podmiotowo neutralne (bezstronne), które charakteryzują się tym, że „nie zależą od szczególnej perspektywy i systemu preferencji podmiotu działającego" ${ }^{27}$, czyli „każda osoba ma powód, żeby chcieć, aby to się zdarzyło"28. Związane są one z moralnym wymogiem promowania pewnych fundamentalnych wartości - przede wszystkim dotyczy to dążenia do minimalizowania bólu i cierpienia. Teorie etyczne typu konsekwencjonalistycznego oparte są na racjach tego typu. Natomiast inne propozycje etyczne mogą brać pod uwagę także racje wyrażające perspektywę wewnętrzną (racje względne wobec podmiotu) ${ }^{29}$. Nagel proponuje uznanie trzech rodzajów racji względnych: racji autonomii, deontycznych i zobowiązań ${ }^{30}$.

25 Por. D.C. Russel, Practical Intelligence and the virtues, Oxford University Press, Oxford 2009, s. 340; N.J.H. Dent, The moral psychology of the virtues, Cambridge University Press, Cambridge 1984, s. 95; C.A.J. Coady, Morality and Political Violence, Cambridge University Press, Cambridge 2008, s. 200; A. Thomas, Thomas Nagel, McGill-Queens University Press, Montreal [etc.] 2009, s. 134. Uwagi powyższych autorów dotyczące możliwości powiązania koncepcji Nagela z etyką cnót są bardzo lakoniczne, jednak mogą stanowić interesujący punkt wyjścia do dalszych rozważań w tym kierunku.

26 T. Nagel, Pytania ostateczne, Fundacja Aletheia, Warszawa 1997, s. 161-176. Zob. też T. Nagel, Equality and Partiality, Oxford University Press, New York-Oxford 1991 oraz M. Pyka, dz. cyt.; B. Polanowska-Sygulska, Pluralizm wartości i jego implikacje w filozofii prawa, Księgarnia Akademicka, Kraków 2008.

27 T. Nagel, Widok zniką, Fundacja Aletheia, Warszawa 1997, s. 208.

28 Tamże, s. 188.

29 Tamże, s. 186-187.

${ }^{30}$ Nagel stosuje termin racje obowiązku, ale sam stwierdza, że nie jest z niego zadowolony. W literaturze wtórnej jest stosowana nazwa racje zobowiazań. Zob. M.. Pyka, dz. cyt. 
Racje autonomii są najbardziej skrajną formą względności wobec podmiotu, ponieważ wyrażają osobiste interesy, plany i pragnienia. Każda jednostka ma do nich prawo, jednak nie zobowiązują one innych osób, żeby je promować ${ }^{31}$. Ich istnienie rozwiązuje problem nadmiernie wymagającej etyki, z którym zmagają się systemy etyczne typu konsekwencjonalistycznego. Racje deontyczne przede wszystkim wyrażają roszczenia do tego, aby nie być traktowanym w nieodpowiedni sposób, a zatem „ograniczają działania, które wolno nam podejmować w służbie wartości bezosobowych lub autonomicznych"32. Wiążą się one z osobową relacją pomiędzy ludźmi i tym, jakie działania wobec innej osoby są niedopuszczalne. $Z$ kolei racje zobowiązań dotyczą relacji z ludźmi, z którymi daną osobę łączą szczególne więzy - naturalne lub o charakterze społecznym. Pozwalają one uzasadnić szczególne preferencje, jakimi jednostka powinna się kierować w swoich wyborach, i usprawiedliwiają specjalną troskę o najbliższych lub walkę o interesy określonych grup.

Uznanie prawomocności zaproponowanych typów racji pozwala uniknąć licznych problemów i paradoksów, do których prowadzi przyjęcie stanowisk takich jak konsekwencjonalizm lub etyka kantowska, bazujących na jednym typie racji. Wydaje się więc, że przedstawiona przez Nagela typologia racji do działania, będąca wyrazem przyjęcia przez niego koncepcji pluralizmu etycznego, jest w ogólnym zarysie propozycją wiarygodną i akceptowalną bez względu na różne możliwe założenia metafizyczne, a ponadto pozwala lepiej zrozumieć, a nawet częściowo rozwiązać podstawowe dylematy etyczne. W związku z tym można poszukiwać sposobów na zwiększenie wykorzystania tej koncepcji nie tylko w rozważaniach teoretycznych, ale również w odniesieniu do istniejących praktyk moralnych. Jedną z możliwości mogłoby być potraktowanie zdolności do ważenia racji jako istotnej dyspozycji, którą należy kształtować już od wczesnych lat życia dziecka.

W publikacjach poświęconych myśli etycznej zwraca się uwagę na to, że teoria złotego środka w odniesieniu do wielu kwestii okazuje się adekwatna i może mieć zastosowanie $\mathrm{w}$ wielu różnych dziedzinach i sytuacjach ${ }^{33}$. Wydaje się więc, że takie ogólne rozumienie złotego środka można odnieść również do ważenia różnych typów racji. Rozumowanie praktyczne, w tym podejmowanie decyzji o charakterze moralnym, związane jest między innymi z odnalezieniem właściwego stopnia obiektywizacji - w decyzjach moralnych wyraża się to w znalezieniu właściwego środka polegającego na zważeniu różnego typu racji prima facie mających znaczenie w danych okolicznościach. W danej sytuacji może występować wielość racji prima facie należących do wszystkich lub tylko niektórych typów. System motywacyjny jest więc „,popychany” w różnych kierunkach i narażony na duże niebezpieczeństwo przypadkowości - w szczególności gdy podmiot nie jest świadomy istnienia różnych typów racji. Wydaje się również, że jednorazowa informacja nie jest wystarczająca do tego, aby różne typy racji były systematycznie rozpoznawane i uwzględniane. Potrzebny jest raczej pewien długotrwały wysiłek podmiotu, aby zarówno u niego samego, jak i u wychowanków ukształtowały się dyspozycje do rozpoznawania

31 T. Nagel, Widok znikad, dz. cyt., s. 202, 204.

32 Tamże, s. 245.

33 Zob. np. B. Russell, The conquest of happiness, Unwin Books, London 1968, s. 148; J.L. Mackie, Ethics: Inventing Right and Wrong, Penguin Books, Harmonsworth 1977. 
normatywnej złożoności otaczającej rzeczywistości. Nieświadomość istnienia różnych typów racji lub brak umiejętności ich uwzględniania może prowadzić do podejmowania niewłaściwych decyzji lub błędnych sądów wartościujących. Może również przyczynić się do tego, że charakter wychowanków kształtowany będzie w taki sposób, że tylko określone typy racji będą brane pod uwagę w systemie motywacyjnym danej osoby.

Związek pomiędzy zdolnością do rozpoznawania i uwzględniania racji różnego typu a cechami charakteru nie budzi szczególnego zainteresowania etyków cnót, tymczasem powiązanie takie wydaje się dosyć istotne. Można to wykazać za pomocą kilku przykładów: osoba, która nie rozpoznaje wagi racji zobowiązań, może aktywnie włączać się w walkę o słuszne ideały, przy jednoczesnym zaniedbywaniu potrzeb najbliższych osób. Ktoś, kto ignoruje racje deontyczne, a jest na przykład policjantem, może być gotowy poświęcić niewinną osobę dla uratowania porządku społecznego (w historii znane były aresztowania niewinnych osób pełniących rolę „kozłów ofiarnych” po to, aby zapobiec zamieszkom itd.). Urzędnik lub policjant, który przecenia rolę racji deontycznych w ich kantowskim, formalistycznym rozumieniu, będzie uznany za bezdusznego służbistę, któremu obce są ludzkie odruchy. Natomiast ci, którzy w sposób nadmierny kierują się racjami autonomii, wykazują cechy egoistów lub egocentryków. Zatem staje się widoczne, że umiejętność prawidłowego rozpoznania i ważenia racji ma wyraźny wpływ na kształtowanie charakteru, a uwrażliwianie na moralną potrzebę uwzględniania różnorodnych racji może przyczynić się do zapobiegania postawom i dyspozycjom, które charakteryzują się ślepotą na normatywną złożoność napotkanych dylematów moralnych.

Zdolność do ważenia racji może zostać uznana za aspekt mądrości praktycznej, i w takim szerokim sensie nawiązuje do myśli Arystotelesa. Umiejętność ta mieści się więc $\mathrm{w}$ arystotelesowskim rozumieniu mądrości praktycznej pod względem formalnym, jednak wykracza poza nią pod względem treści, ponieważ odnosi się do racji, a ponadto dotyczy racji różnych typów, jako że zaproponowane tu ujęcie nawiązuje do pluralizmu etycznego Nagela.

Jeśli racje odnoszą się do czynników i okoliczności, jakie należy brać pod uwagę przy podejmowaniu decyzji ${ }^{34}$, to warto zauważyć, że taka propozycja może współgrać z kontekstualnym charakterem etyki cnót, na który kładzie nacisk Natasza Szutta ${ }^{35}$. Wynika z tego, że postulat jak najwcześniejszego uczenia zdolności do ważenia racji wbrew pozorom nie stoi w sprzeczności z założeniami etyki cnót ani nie musi oznaczać wprowadzania modelu niedyrektywnego w miejsce etyki cnót. Zdolność do ważenia racji może bowiem zostać potraktowana jako jedna z cnót, która łączy w sobie wymiar etyczny i intelektualny. Wrażliwość na kontekst sytuacyjny i złożoność problematyki

${ }^{34}$ Aby nie odchodzić od głównego problemu, nie analizujemy tu różnych ontologicznych możliwości, jeśli chodzi o sposób istnienia racji. Wydaje się, że proponowane ujęcie może być zaakceptowane zarówno przez zwolenników realizmu racji, do których należy Nagel, jak i na przykład przez przedstawicieli konstruktywizmu.

${ }^{35}$ N. Szutta, Wychowanie moralne ..., dz. cyt., s. 115-117. Propozycja uwrażliwiania dzieci na złożoność problematyki moralnej oraz uczenie dostrzegania i uwzględniania rozmaitych czynników (czyli de facto racji różnego typu) przy podejmowaniu decyzji w określonych, faktycznie występujących sytuacjach, jest odporna na zarzut Nataszy Szutty wobec metod niedyrektywnych, które propagują edukację moralną polegającą na rozważaniu abstrakcyjnych dylematów (tamże, s. 122). 
moralnej może współistnieć zarówno z przyswajaniem pewnych ogólnych zasad, jak i z kształtowaniem różnorodnych cnót.

Kolejnym wymiarem wykorzystania współistnienia różnych typów racji w etyce cnót mogłoby być nałożenie moralnych ograniczeń na metody stosowane w procesie kształtowania charakteru. Jedno $\mathrm{z}$ istotnych ograniczeń w odniesieniu do metod wychowania stanowią racje autonomii ${ }^{36}$. Wzmacniają one argumenty na rzecz wprowadzenia zindywidualizowanych metod wychowawczych i elastyczności, jeśli chodzi o oczekiwania wobec wychowanków. Czynnikiem mającym charakter ograniczający jest również istnienie racji deontycznych. Nagel poświęca wiele miejsca na obronę ich zasadności, dlatego jest uznawany za jednego z najważniejszych współczesnych przedstawicieli deontologii ${ }^{37}$. Rozpoznanie ważności racji deontycznych ma istotne znaczenie w procesie kształtowania pożądanych cech charakteru - pozwala bowiem unaocznić to, że jeśli stosowane przez jakąś osobę lub instytucję metody wychowawcze obejmują na przykład zastraszanie, naruszanie prywatności lub pozbawianie poczucia własnej wartości, to bez względu na stawiane cele poprzez swoje metody działania dają one rację ku temu, aby autorytet wychowawcy został zakwestionowany. Zatem uznanie prawomocności różnych typów racji zaproponowanych przez Nagela może mieć wpływ na proces kształtowania cnót na kilku poziomach. Od strony teoretycznej typologia racji może służyć jako element rozpoznania złożoności problematyki moralnej. Od strony praktycznej ma zastosowanie na poziomie wychowawcy przy wdrażaniu wychowanka do rozpoznania różnego typu racji i do nabywania umiejętności znajdowania pomiędzy nimi właściwego w danej sytuacji „środka”, a także jako ograniczenie dopuszczalnych metod. Na poziomie wychowanka może wspomóc moralne uzasadnienie odmowy uznania autorytetu wychowawcy, jeśli łamie on zasady związane $\mathrm{z}$ racjami deontycznymi i racjami autonomii. $\mathrm{W}$ ten sposób zastosowanie przedstawionej typologii racji może być jednym z elementów zbliżania etyki cnót do modelu niedyrektywnego, akcentującego umiejętność krytycznego myślenia i wnikliwej oceny otaczającej rzeczywistości.

\section{Podsumowanie}

Rozpoznanie złożoności problematyki moralnej prowadzi do wniosku, że współistnienie różnych typów racji powinno być uwzględnione w procesie formowania stałych dyspozycji, które przejawiają się w podejmowanych decyzjach i działaniu. Uwrażliwianie wychowanków na pojawianie się w określonych sytuacjach różnorodnych typów racji o różnej wadze powinno być stałym elementem edukacji moralnej i może stanowić ten aspekt kognitywno-afektywnego ujęcia etyki cnót, który najbardziej zbliża ją do modelu niedyrektywnego. Wydaje się, że warto podjąć taką próbę, ponieważ model niedyrektywny w najdalszy sposób odchodzi od metod typowych dla indoktrynacji i umożliwia kształtowanie elastyczności, wnikliwości i krytycyzmu.

${ }^{36}$ Stanowią takie ograniczenie zarówno w sensie faktycznym (racje w sensie wyjaśniającym), jak i normatywnym (racje w sensie uzasadniającym).

${ }^{37}$ T. Nagel, Pytania ostateczne, dz. cyt., s. 71-95; T. Nagel, Widok znikad, dz. cyt., s. 214-219. 
Akceptacja Nagelowskiej typologii racji mogłaby mieć również dodatkowe znaczenie w procesie wychowania. Wiąże się bowiem z problematyką dopuszczalnych metod (racje deontyczne), a także z koniecznością uwzględnienia indywidualności i potrzeb wychowanków (racje autonomii). Współistnienie rożnych typów racji ma więc znaczenie co najmniej dwustopniowe: z jednej strony wyraża się materialnie w przekazywanej treści, która powinna obejmować kształtowanie dyspozycji do uwzględniania poszczególnych typów racji, a z drugiej strony dotyczy metod stosowanych w procesie kształtowania charakteru. Uwidacznia się tu jedno z trudniejszych wyzwań w dziedzinie mądrości praktycznej - pogodzenie oczekiwań dziecka w kwestii uzyskiwania klarownych komunikatów w dziedzinie praktyk moralnych z koniecznością nauczenia elastyczności i umiejętności spoglądania na problemy moralne $\mathrm{z}$ różnorakich perspektyw.

\section{Bibliografia}

Arystoteles, Etyka Nikomachejska, PWN, Warszawa 2012.

Coady C.A.J., Morality and Political Violence, Cambridge University Press, Cambridge 2008.

Cohut M., Nature vs. nurture: Do genes influence our morals?, "Medical News Today", 27 Feb. 2019, https:/www.medicalnewstoday.com/articles/324561.php [dostęp: 6.03.2019].

Dent N.J.H., The moral psychology of the virtues, Cambridge University Press, Cambridge 1984.

Doris J., Lack of character. Personality and moral behavior, Cambridge University Press, Cambridge 2002.

Glannon W., Psychofarmacology and functional neurosurgery: manipulating memory, thought and mood, [w:] R.L. Sandler (red.), Ethics and emerging technologies, Palgrave Macmillan, Boston 2014.

Górska J., Wstyd jako emocja wywoływana społecznie, „Societas/Communitas” 2012, nr 2(14).

Harman G., Moral philosophy meets moral psychology: virtue ethics and the fundamental attribution error, "Proceedings of the Aristotelian Society" 1999, No. 109.

Heller A., Power of shame. A rational perspective, Routledge, London 1985.

Jaśtal J. (red.), Etyka i charakter, Wydawnictwo Aureus, Kraków 2004.

Jaśtal J., Natura cnoty. Problematyka cnoty w neoarystotelesowskiej etyce cnót, Księgarnia Akademicka, Kraków 2009.

Kahneman D., Pułapki myślenia. O myśleniu szybkim i wolnym, Media Rodzina, Poznań 2012.

Lenman J., Reasons for Action: Justification, Motivation, Explanation, https://plato.stanford. edu/entries/reasons-just-vs-expl/ [dostęp: 4.09.2019].

Mackie J.L., Ethics: Inventing Right and Wrong, Penguin Books, Harmonsworth 1977.

Nagel T., Equality and partiality, Oxford University Press, New York 1991.

Nagel T., Pytania ostateczne, Fundacja Aletheia, Warszawa 1997.

Nagel T., Widok znikąd, Fundacja Aletheia, Warszawa 1997. 
Polanowska-Sygulska B., Pluralizm wartości i jego implikacje w filozofii prawa, Księgarnia Akademicka, Kraków 2008.

Pyka M., Działanie, moralność, podmiotowość: wokół myśli Thomasa Nagela, Księgarnia Akademicka, Kraków 2016.

Russel D.C., Practical Intelligence and the virtues, Oxford University Press, Oxford 2009.

Russell B., The conquest of happiness, Unwin Books, London 1968.

Rutkowski M., Dlaczego potrafimy działać moralnie?, Wydawnictwo Naukowe Scholar, Warszawa 2010.

Sagan C., Druyan A., Cienie zapomnianych przodków. W poszukiwaniu naszej tożsamości, Zysk i S-ka, Poznań 2000.

Sandler R.L. (red.), Ethics and emerging technologies, Palgrave Macmillan, Boston 2014.

Szutta N., Czy istnieje coś, co zwiemy moralnym charakterem i cnota? Dyskusja z sytuacjonistyczna krytyka etyki cnót, Wydawnictwo Academicon, Lublin 2017.

Szutta N., Dyskusja z sytuacjonistyczna krytyka etyki cnót: odpowiedź na zarzuty Gilberta Harmana, „Diametros” 2012, nr 31.

Szutta N., Współczesna etyka cnót: projekt nowej etyki?, Wydawnictwo Uniwersytetu Gdańskiego, Gdańsk 2008.

Szutta N., Wychowanie moralne z perspektywy etyki cnót, „Diametros” 2015, nr 46.

Szutta N., Szutta A. (red.), W poszukiwaniu moralnego charakteru, Wydawnictwo Academicon, Lublin 2015.

Thomas A., Thomas Nagel, McGill-Queens University Press, Montreal [etc.] 2009.

Toch H., The social psychology of social movements, Methuen, London 1966.

Williams B., Shame and necessity, University of California Press, Berkeley 1993.

Winn D., Manipulowanie umystem: pranie mózgu, warunkowanie, indoktrynacja, Wydawnictwo Unus, Wałbrzych 2003.

Winner L., Technologies as forms of life, [w:] R.L. Sandler (red.), Ethics and emerging technologies, Palgrave Macmillan, Boston 2014.

Wojtanowska W., Filozofia moralna Thomasa Nagela a wspótczesna etyka cnót, Wydawnictwo Naukowe Uniwersytetu Papieskiego Jana Pawła II w Krakowie, Kraków 2019.

Żuradzki T., Internalizm i eksternalizm $w$ metaetyce, Wydawnictwo Uniwersytetu Jagiellońskiego, Kraków 2012.

\section{Streszczenie \\ O możliwości zastosowania Nagelowskiej typologii racji do działania we współczesnej etyce cnót}

$\mathrm{W}$ artykule podejmuję próbę wzięcia udziału w dyskusji odbywającej się $\mathrm{w}$ ramach współczesnej etyki cnót. Przedstawiam jeden z głównych problemów związanych z procesem kształtowania cnót i argumentuję, że większe zbliżenie etyki cnót do modelu 
niedyrektywnego pozwoliłoby zmniejszyć adekwatność zarzutów wysuwanych wobec metod i mechanizmów wykorzystywanych w procesie kształtowania charakteru. Jako jeden z możliwych sposobów zbliżenia etyki cnót do modelu niedyrektywnego wskazuję uwzględnienie zagadnienia Nagelowskiej typologii racji do działania.

Słowa kluczowe: etyka cnót, wychowanie, racje do działania, Thomas Nagel, pluralizm etyczny

\section{Summary \\ On the possibility of applying Nagel's typology of reasons for action in contemporary virtue ethics}

In this article, I contribute to the discussion on contemporary virtue ethics. I present one of the major problems connected with moral education and I argue that modifying virtue ethics in order to make it more similar to the non-directive model would reduce the strength of some of the objections against the methods and mechanisms used in the process of shaping character. As one of the possible ways of bringing virtue ethics closer to the non-directive model I suggest taking into account Thomas Nagel's typology of reasons for action.

Keywords: virtue ethics, upbringing, reasons for action, Thomas Nagel, ethical pluralism 


\title{
Angelika Gieraś
}

\author{
angelikagieras@gmail.com
}

Uniwersytet Warszawski

\section{Problem demokracji w Unii Europejskiej}

Jak zauważa Roman Kuźniar, „Unia Europejska jest zupełnie wyjątkowym związkiem chemicznym w przyrodzie stosunków międzynarodowych, związkiem, który jest wytworem unikalnych i niepowtarzalnych okoliczności historycznych"'. Mimo że w dzisiejszych czasach integracja europejska kojarzy nam się głównie z integracją gospodarczą czy też polityczną, to jednak z historycznego punktu widzenia Unia Europejska zbudowana jest na potężnym dorobku cywilizacyjnym Europy: greckiej filozofii i demokracji, prawie rzymskim oraz na tradycji judeochrześcijańskiej. Według jednej z definicji integracja europejska to ,szerokie pojęcie odnoszące się do idei, historii, formalno-instytucjonalnego stanu współczesnych struktur integracyjnych oraz docelowego rezultatu podejmowanych obecnie działań"2. Należy w tym miejscu zauważyć, że główną zasadą, na której opiera i dokonuje się integracja europejska jest równość i niedyskryminacja, a więc wydaje się naturalną częścią reżimu demokratycznego. Pierwsza z nich, czyli równość, ma szerszy zakres niż druga. Niedyskryminacja ma bowiem tylko i wyłącznie negatywny wydźwięk, nie można dyskryminować nikogo ze względu na kraj pochodzenia, religię, płeć lub kolor skóry. Zasada równości zawiera w sobie zarówno element niedyskryminacji, jak i dodatkowo element pozytywny, to znaczy zakłada, że podejmujemy pozytywne działania, które mają na celu zachowanie równości i równowagi. Jak podkreślają badacze Marek Rewizorski i Beata Przybylska-Maszner, „Instytucje Unii Europejskiej wywierają w coraz większej mierze wpływ na politykę UE, jej państw członkowskich oraz codzienne życie

\footnotetext{
${ }^{1}$ R. Kuźniar, Międzynarodowa tożsamość Europy (UE), [w:] E. Haliżak, S. Parzymies (red. nauk.), Unia Europejska: nowy typ wspólnoty międzynarodowej, Oficyna Wydawnicza Aspra-JR, Warszawa 2012, s. 44.

${ }^{2}$ Hasło: integracja europejska, [w:] R. Duda i in., Unia Europejska - stownik encyklopedyczny, Wydawnictwo Europa, Wrocław 2004.
} 
ich obywateli”33. Przytoczony cytat znakomicie ujmuje nową, postlizbońską rzeczywistość, w której funkcjonuje Unia Europejska oraz pokazuje znaczenie, jakie organizacja ta zdobyła na arenie międzynarodowej w ciągu kilkudziesięciu lat swego istnienia.

Kryteria kopenhaskie uchwalone przez Radę Europejską w 1993 roku w Kopenhadze precyzyjnie określają warunki, które muszą spełnić kandydaci, aby stać się członkami Unii Europejskiej. Możemy wśród nich wyróżnić kryterium istnienia instytucji gwarantujących stabilną demokrację oraz rządy prawa. Na poziomie narodowym demokracja charakteryzuje się trójpodziałem władzy, konstytucją, legalnie działającym rządem i opozycją, niezależnością i niezawisłością sądów, wyborami parlamentarnymi (demokracja pośrednia), społeczeństwem obywatelskim (demokracja bezpośrednia - inicjatywa ustawodawcza, referenda), zasadą poszanowania praw mniejszości oraz zasadą pluralizmu. Na poziomie ponadnarodowym nie możemy wyróżnić takich cech demokracji, ponieważ na niego zostały delegowane tylko niektóre kompetencje państwa, zaś sam reżim demokratyczny jest nieodłączną cechą każdego państwa członkowskiego. Teza niniejszej pracy brzmi: demokracji w Unii Europejskiej nie można analizować pod kątem elementów demokratycznego państwa prawa. Należy poszukać odpowiedzi na następujące pytania badawcze: Czy w Unii Europejskiej można mówić o trójpodziale władzy? Czy instytucje UE szanują zasadę równości wszystkich państw? Czy Unia Europejska dopełniła należytej staranności w zapewnieniu demokratycznych reguł postępowania wewnątrz organizacji? Czy sposób podejmowania decyzji jest demokratyczny? Czy państwa członkowskie powinny definiować problem deficytu demokracji?

W wymiarze ustrojowym Unia Europejska to wspólnota gospodarcza i polityczna. Podejmuje ona działania w granicach kompetencji przyznawanych jej w traktatach, a te z kolei są negocjowane przez państwa członkowskie. Do przyjęcia traktatu wymagana jest jednomyślność. Wydaje się zatem, że na obowiązujące reguły prawne dobrowolnie zgodziły się państwa członkowskie. To one decydowały o formie i treści traktatu lizbońskiego. Poprzez przyjęcie tego aktu prawnego państwa dały podstawę do działalności organizacji oraz dobrowolnie zgodziły się na obecny kształt i wymiar UE.

W systemie politycznym Unii Europejskiej występuje demokracja, lecz można dostrzec problemy z nią związane. Najlepszym przykładem jest problem z określeniem władzy wykonawczej i ustawodawczej. Jak słusznie zauważa M. Poboży, „Unia Europejska, w szczególności jej instytucje, są podmiotem władzy politycznej, która przede wszystkim, w wyniku globalizacji przekroczyła granice państw i może być realizowana poza państwowym systemem politycznym. Władzę tę przekazały instytucjom państwa członkowskie"4. Trybunał Sprawiedliwości Unii Europejskiej jest władzą sądowniczą, która jest w zasadzie jako jedyna wydzielona i efektywna. Podkreśla się autonomię prawną

${ }^{3}$ M. Rewizorski, B. Przybylska-Maszner, System instytucjonalny Unii Europejskiej po traktacie z Lizbony: aspekty polityczne i prawne, Difin, Warszawa 2012, s. 14.

${ }^{4}$ M. Poboży, Zasada podziału władzy w systemie instytucjonalnym Unii Europejskiej, Oficyna Wydawnicza Aspra-JR, Warszawa 2014, s. 263. 
UE, bezpośrednią wewnątrzpaństwową skuteczność prawa UE oraz prymat prawa UE nad prawem krajowym ${ }^{5}$.

Instytucja międzyrządowa, jaką jest Rada Unii Europejskiej, stanowi zarówno legislatywę, jak i egzekutywę, ponieważ składa się z przedstawicieli rządów państw członkowskich i jednocześnie uczestniczy w procesie podejmowania aktów prawnych, natomiast we Wspólnej Polityce Zagranicznej i Bezpieczeństwa podejmuje decyzje. W Unii Europejskiej występuje zatem kryzys instytucjonalny, który przejawia się w problemie przenikania kompetencji ustawodawczych z wykonawczymi. Należy w tym miejscu dodać, że kwestie polityk międzyrządowych są w znacznie mniejszym stopniu uregulowane w traktatach niż kwestie polityk ponadnarodowych. Zastrzeżenia budzi też sam proces wypracowywania decyzji przy poszanowaniu zasady równości wszystkich państw. Wydaje się, że podczas spotkań RUE czy RE bardzo ważną rolę odgrywają atrybuty, jakimi dysponuje poszczególne państwo członkowskie. Mam tu na myśli to, że państwo z dużą populacją i dobrze rozwinięte gospodarczo ma większe szanse na postulowanie swoich przekonań, a co za tym idzie, ma większe szanse na przekonanie innych do swoich argumentów, a to z kolei wiąże się z końcowym sukcesem tego państwa, ponieważ decyzja przyjęta przez większość w drodze głosowania może być propozycją jednego silnego polityka reprezentującego silne państwo. W międzyrządowości nie ma parytetów, każde państwo jest odpowiedzialne za swój ewentualny sukces lub porażkę. Państwa mniejsze i o znacznie niższym wzroście PKB są zależne od państw wysokorozwiniętych o wyższym wzroście PKB, na przykład Malta w rozmowie z Niemcami raczej ma słabe argumenty. Nie jest to negocjacja równego $\mathrm{z}$ równym, a tego typu problemy nie są normatywnie uregulowane. Bardzo ważną rolę odgrywają zatem umiejętności polityka reprezentującego dany kraj: jego sztuka retoryki, dyplomacji, sztuka forsowania swojego stanowiska i dobre relacje z krajami sąsiadującymi mogą wpływać na podejmowanie decyzji na szczeblu międzyrządowym. Może to budzić pewien niepokój, ponieważ w tym miejscu możemy się zastanowić nad tym, czy wartości UE, w tym głównie równość, mają zastosowanie w rzeczywistym działaniu. Zarówno obywatele, jak i sami przedstawiciele państw członkowskich oczekują, aby te zasady były szanowane oraz przestrzegane na poziomie UE. Czy w TSUE ma znaczenie, czy wyrok wydaje sędzia z Malty, czy z Francji? Czy w Parlamencie Europejskim ważne jest, ilu Polaków zasiada we frakcji konserwatywnej, a ilu w liberalnej? Czy w Komisji Europejskiej ważne jest, czy tekę komisarza ds. rynku wewnętrznego otrzyma osoba z Portugalii, czy z Francji? Na wszystkie pytania odpowiedź brzmi nie, ponieważ kompetencje w tych instytucjach zostały dobrowolnie delegowane z państw na poziom unijny i są wykonywane zgodnie z obowiązującą literą traktatu. Należy dostrzec problem ze słabą i niską efektywnością demokracji bezpośredniej w Unii Europejskiej. Może być to spowodowane brakiem poczucia wspólnej tożsamości europejskiej. Społeczeństwo obywatelskie i demokracja są płaszczyznami wzajemnie od siebie zależnymi. Jedno bez drugiego nie istnieje. Niestety, jak pokazują badania Eurobarometru, zdecydowana większość Europejczyków czuje się związana bardziej z państwem narodowym niż z Unią Europejską. Dostrzec zatem można

5 K.A. Wojtaszczyk, J. Szymańska (red.), Deficyt demokracji w Unii Europejskiej, Wydział Dziennikarstwa i Nauk Politycznych Uniwersytetu Warszawskiego, Warszawa 2011, s. 11. 
brak europejskiego demos. Obywatele UE nie czują się na tyle silni i wpływowi, by móc oddziaływać na decyzje podejmowane przez Wspólnotę. Z drugiej zaś strony wiele decyzji kluczowych dla procesu integracji jest podejmowanych przez obywateli państw członkowskich na podstawie prawa obowiązującego w państwie członkowskim (na przykład referenda krajowe o członkostwo, wybory do PE), nie zaś na zasadach ogólnie i odgórnie przyjętych przez UE. W każdym państwie odbywa się to w inny sposób. Obywatele czują, że podejmują decyzję dotyczącą Unii, ale w ramach swojego kraju pochodzenia, natomiast nie jako obywatele Europy. Decyzje te są wiążące, aczkolwiek tego typu działania nie budują poczucia odpowiedzialności europejskiej. Oczywiście można w tym miejscu wskazać wiele niezależnych od obywateli ograniczeń, takich jak język, położenie geograficzne, brak sieci europejskich kontaktów, brak uniwersalnej płaszczyzny wymiany poglądów na temat działalności UE. To wszystko utrudnia budowanie europejskiego kapitału społecznego. Kolejną kwestią mogą być wybory do Parlamentu Europejskiego. Obywatele wybierają wszak swoich narodowych reprezentantów pochodzących z partii zarejestrowanych w kraju pochodzenia, a nie polityków partii stricte europejskich. Należy również przypomnieć, że na początku lat 50. integracja europejska miała wymiar gospodarczy, później nabrała wymiaru politycznego, zaś do czasu występowania kryzysów nie miała charakteru obywatelskiego. Chodzi o to, że obywatele nie byli zaangażowani w proces europeizacji dopóty, dopóki skutki integracji nie zaczęły relatywnie wpływać na ich codzienne życie. Jak dziś wiemy, integracja społeczna i budowanie wspólnotowości okazało się dużo trudniejsze niż integracja gospodarcza. Badania Eurobarometru pokazują, że obywatele państw członkowskich zdecydowanie częściej wybierają swoją tożsamość narodową jako pierwszą. Powstaje problem kształtowania się społeczeństwa obywatelskiego na poziomie ponadnarodowym. Możemy dostrzec brak zainteresowania społeczeństw działaniami UE. Traktat z Lizbony wprowadził inicjatywę ludową, dającą obywatelom możliwość zgłaszania projektów legislacyjnych, jednak efektywność tego instrumentu jest znikoma. Z normatywnego punktu widzenia jest to znakomity instrument do angażowania obywateli w proces integracji. Jednak z praktycznego punktu widzenia nie spełnia w ogóle oczekiwań, gdyż obywatele nie wykazują zainteresowania tą formą aktywności. Jeśli już uda się wymyślić jakiś wspólny projekt, to w późniejszych etapach albo trudno jest zmobilizować obywateli do głosowania, albo Komisja Europejska odrzuca projekt, uzasadniając, że poruszany temat wykracza poza jej kompetencje $\mathrm{e}^{6}$. Brak europejskiego demos wyraża się również poprzez brak debaty europejskiej podczas wyborów do PE. Chociaż podjęto próby zaangażowania wolontariuszy szerzących informacje o wyborach do PE w ramach ogólnoeuropejskiej kampanii This time I am voting prowadzonej przez Parlament Europejski, to jednak platforma ta nie była skutecznym źródłem przekazywania informacji. Kampaniom do parlamentów narodowych towarzyszą duże emocje i różne nastroje społeczne, natomiast podczas wyborów do PE zainteresowanie społeczeństw nieustannie malało, aż do wyborów w 2019 roku, kiedy nastąpił wzrost frekwencji z 42,6\%

${ }^{6}$ Zob. więcej http://www.europarl.europa.eu/RegData/etudes/STUD/2014/509982/IPOL STU(2014)509982_EN.pdf [dostęp: 3.03.2020]. 
w 2014 roku do 50,6\% w 2019 roku . Może to mieć związek z kryzysem społecznym, który obserwujemy w UE - do 2014 roku aktywność obywateli systematycznie spadała. Społeczeństwa są niezadowolone z efektywności prac organizacji, a to rodzi tendencje do nastrojów eurosceptycznych i mobilizacji tego elektoratu.

Kolejnym problemem może być poniekąd przejawiający się deficyt demokracji proceduralnej w Unii Europejskiej. Dobrym przykładem jest chociażby sposób wyboru kandydata na stanowisko przewodniczącego Rady Europejskiej. Z artykułu 15 ust. 5 Traktatu o Unii Europejskiej (TUE) wynika, że instytucja wybiera swojego przewodniczącego większością kwalifikowaną. Należy jednak zaznaczyć, iż w dotychczasowej praktyce wybór kandydata na to stanowisko odbywał się w drodze ustalenia konsensusu państw członkowskich, a co za tym idzie - uzyskaniem jednomyślności. W postlizbońskiej rzeczywistości możemy zaobserwować, że dla państw członkowskich ważniejsza jest spójność oraz kultura konsensusu aniżeli forsowanie własnych stanowisk, potencjalnie odrębnych od innych członków. Z drugiej strony zaskakujący wydaje się fakt, że traktaty przewidują sprawowanie tak ważnego mandatu, bo przecież reprezentującego wszystkie państwa członkowskie, bez konieczności uzyskania zgody wszystkich państw, a jedynie wymagają zgody większości państw członkowskich. Zatem w zasadzie prawnie jest przewidziana sytuacja, w której mała grupa państw może zostać przegłosowana, a i tak będzie zobligowana do brania aktywnego udziału w pracach instytucji z uwagi na interes narodowy oraz zagrożenie wykluczeniem politycznym. Obawy budzi sam fakt wyboru kandydata na to stanowisko, nie zaś sposób głosowania jego kandydatury. Niepokoje wzbudza sytuacja, w której obywatele państw europejskich nie mają żadnego realnego wpływu na podjęcie decyzji czy na wskazanie kandydata, który mógłby sprawować rolę politycznego przywódcy UE. Czy możemy zatem mówić o demokracji? Z drugiej zaś strony wybór stałego przewodniczącego Rady Europejskiej jest bez wątpienia uzależniony od woli państw członkowskich ${ }^{8}$, które z kolei są reprezentowane przez narodowych przywódców wybranych w demokratycznych wyborach. Trzeba przyznać, że wybór kandydata na stałego przewodniczącego RE owiany jest tajemnicą, tak więc obywatele UE nie mają realnego wpływu na decyzję. Nie ma jednak sprecyzowanych oficjalnych kryteriów, jakie musi spełniać polityk kandydujący na urząd stałego przewodniczącego RE. Nie ma określonego wieku kandydata, nie ma określonego stażu w polityce, nie ma określonego doświadczenia, nie ma określonego wykształcenia. Wydaje się zatem, że decyzja o wyborze kandydata jest zupełną dowolnością silnych przywódców państw europejskich, tak zwaną dyplomatyczną grą polityczną. Z jednej strony rządzi tandem francusko-niemiecki, który nie potrzebuje wystawiać swojego kandydata na przewodniczącego, bo w gruncie rzeczy szukanie konsensusu mogłoby zaszkodzić forsowaniu narodowych interesów. Z drugiej zaś strony słabsze i mniejsze państwa są skazane na dobrą wolę dużych państw, a demokracja opiera się przecież na zasadzie równości. Dodajmy do tego, że europejskie społeczeństwo o potencjalnych kandydatach, negocjacjach oraz

\footnotetext{
7 Zob. https://europarl.europa.eu/election-results-2019/pl/frekwencja/ [dostęp: 3.03.2020].

8 M.J. Tomaszyk, Unia Europejska w dwa lata od wejścia w życie Traktatu z Lizbony, „Rocznik Integracji Europejskiej” 2011, nr 5, s. 159.
} 
końcowym wyniku wyboru dowiaduje się z mediów, w których niekiedy trudno odbiorcy odróżnić plotki od faktów.

Podstawowym kryterium przynależności jakiegokolwiek państwa do Unii Europejskiej jest zagwarantowanie „stabilności instytucji gwarantujących demokrację, praworządne państwo, prawa człowieka oraz poszanowanie i ochronę mniejszości”" . Demokracja wydaje się zatem najważniejszym kryterium przyjęcia i podstawową przesłanką kontynuowania członkostwa w organizacji. Stwierdzenie, że Unia jest niedemokratyczna, wydaje się więc błędne. Oczywisty jest fakt, że państwa większe oraz bogatsze będą forsować swoje stanowiska, a może to państwa mniejsze i biedniejsze nie chcą sprzeciwiać się woli państw, od których są poniekąd gospodarczo uzależnione? Zadziwiające jest to, że szefowie państw i rządów, biorący udział w szczytach organizowanych przez stałego przewodniczącego Rady Europejskiej, bardzo rzadko, a w zasadzie nigdy, nie wychodzą z tych spotkań i nie przekazują do opinii publicznej negatywnych aspektów rozmów. Politycy nie mówią o porażkach, jakie dany kraj poniósł podczas negocjacji, ani nie informują dziennikarzy o swoich realnych wpływach na wypracowanie konsensusu. Oczywiście przewodniczący RE publikuje konkluzje, które udało się ustalić podczas rozmów, ale rzadko kiedy jakieś europejskie państwo przyznaje się do porażek negocjacyjnych. Zazwyczaj są sami zwycięzcy. W tym kontekście można się zastanowić nad tym, czy jest to przejaw patologii demokracji i kwestia niedotrzymania należytej staranności poszanowania zasad demokracji przy tworzeniu prawa unijnego. $Z$ jednej strony może to być przejaw po prostu gry politycznej, $\mathrm{z}$ drugiej zaś strony mamy dokładnie sprecyzowane prawo traktatowe ${ }^{10}$, ogólnie przyjęte wartości, normy i reguły unijnego postępowania. Dodatkowo w prawie unijnym mamy bardzo szczegółowo określone kompetencje poszczególnych instytucji, wewnętrzny sposób głosowania i podejmowania decyzji, mamy jasno sprecyzowaną liczbę europosłów adekwatną do liczebności ludności danego państwa. Zasady te wydają się słuszne, sprawiedliwe i potrzebne do sprawnego funkcjonowania UE. Każde państwo członkowskie w razie jakichkolwiek zmian ma realny wpływ na negocjacje traktatów, wymagana jest przecież zgoda wszystkich członków UE. Wydaje się zatem, że z normatywnego punktu widzenia działania unijne powinny być przejrzyste zarówno dla aktorów politycznych, jak i obywateli całej UE.

Jeżeli wśród państw członkowskich powstanie idea Europy federalnej, Europy imperium albo Europy a'la carte, to zarówno system prawny, jak i system aksjologiczny można dostosować do współczesnych potrzeb. W zależności od tego, jakie przyszła Unia będzie miała potrzeby, takie działania można podejmować. Bez wątpienia potrzebna jest większa edukacja obywateli i skuteczniejsze budowanie europejskiego kapitału społecznego, politycznego i gospodarczego. Proces ten jest trudniejszy w ramach całej UE niż w ramach poszczególnych państw członkowskich. Społeczeństwa europejskie

9 M. Witkowska, Uwarunkowania istnienia społeczeństwa obywatelskiego w Unii Europejskiej, https:// www.researchgate.net/publication/266160448 Witkowska_M_Uwarunkowania istnienia spoleczenstwa ob ywatelskiego_w_Unii_Europejskiej_s_15-48 [dostęp: 3.03.2020].

${ }_{10}$ Traktat o Ūnii Europejskiej, http://oide.sejm.gov.pl/oide/index.php?option=com content\&view=article-

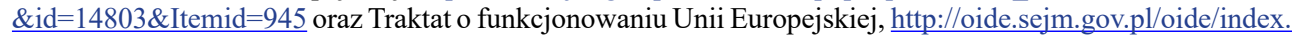
php?option $=$ com content $\&$ view=article $\& i d=14804 \&$ Itemid=946 [dostęp: 15.06.2019]. 
mogą być zniechęcone do podejmowania działań pogłębiających integrację, ponieważ widzą brak efektywności i skuteczności w działaniach Wspólnoty. Unia Europejska zagwarantowała państwom sprawiedliwe zasady członkostwa, a brak poszanowania zasad demokracji wewnątrz danego państwa jest kryterium dyskwalifikującym przynależność do Wspólnoty, zarówno wśród aktualnych członków, jak i potencjalnych kandydatów. Komisja Europejska jest „strażnikiem traktatów” i jest kompetentna co do oceny działań podejmowanych przez rządy państw europejskich. Na arenie międzynarodowej Unia Europejska wydaje się postrzegana jako demokratyczna organizacja międzynarodowa, zrzeszająca demokratyczne państwa europejskie. Wspólna chęć działania i dobra wola jej członków mogą zagwarantować sukces całej Unii Europejskiej.

\section{Bibliografia}

Haliżak E., Parzymies S. (red.), Unia Europejska: nowy typ wspólnoty międzynarodowej, Oficyna Wydawnicza Aspra-JR, Warszawa 2012.

Hasło: integracja europejska, [w:] Duda R. i in., Unia Europejska - stownik encyklopedyczny, Wydawnictwo Europa, Wrocław 2004.

Poboży M., Zasada podziału władzy w systemie instytucjonalnym Unii Europejskiej, Oficyna Wydawnicza Aspra-JR, Warszawa 2014.

Rewizorski M., Przybylska-Maszner B., System instytucjonalny Unii Europejskiej po traktacie z Lizbony: aspekty polityczne i prawne, Difin, Warszawa 2012.

Tomaszyk M.J., Unia Europejska w dwa lata od wejścia w życie Traktatu z Lizbony, „Rocznik Integracji Europejskiej” 2011, nr 5.

Traktat o funkcjonowaniu Unii Europejskiej, wersja skonsolidowana, http://oide.sejm.gov. pl/oide/index.php?option $=$ com content $\&$ view $=$ article \&id $=14804 \&$ Itemid $=946$ [dostęp: 15.06.2019].

Traktat o Unii Europejskiej, wersja skonsolidowana, http://oide.sejm.gov.pl/oide/index.php?op-

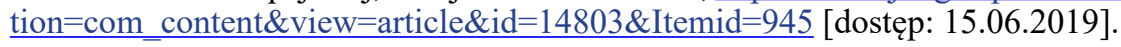

Witkowska M., Uwarunkowania istnienia społeczeństwa obywatelskiego w Unii Europejskiej. Stan prawny uwzględniajacy zmiany wprowadzone traktatem z Lizbony, [w:] tejże (red.), Społeczeństwo obywatelskie w procesie integracji europejskiej, Oficyna Wydawnicza Aspra-JR, Warszawa 2009.

Wojtaszczyk K.A., Szymańska J. (red.), Deficyt demokracji w Unii Europejskiej, Wydział Dziennikarstwa i Nauk Politycznych Uniwersytetu Warszawskiego, Warszawa 2012. 


\section{Galyna Biletska}

halyna.forwork@gmail.com

Akademia Humanistyczno-Ekonomiczna w Łodzi

\section{Analysis of support levels for far-right political parties in Sweden and France}

This paper summarises my research examining the increase in support gained by rightwing political parties in Sweden and France over recent years. In my research, support levels among populations are measured. Factors contributing to the increase in far-right support are suggested. Internal factors such as the rhetorical strategies of political parties, the economic situation, and external factors that are interpreted as a threat to national identity and/or economic stability of the country, are considered. The research seeks to understand the high levels of support for right and far-right political parties in Sweden and France - countries in which such support previously was not as openly and vocally expressed. This paper discusses the high levels of support for the far-right in Sweden and France over the last decade, and the way specific political crises are presented in the rhetoric of far-right parties and groups. It considers whether there is a pattern of factors (both internal and external) that encourage people to support far-right political parties and groups.

The hypothesis guiding the research is as follows: Far-right political parties get higher levels of popular support when the country is involved in a political crisis that can be interpreted as a threat to economic stability and/or preservation of national identity of the core population. A particular unfavourable political/economic situation serves as a trigger for an increase in populist far-right rhetoric, populism, and higher levels of support of the latter. It is argued that, in the case of France and Sweden, such a trigger has been the recent chain of migration crisis events. In the analysis of the rise of the far-right in these two countries, the following issues are considered: the history of nationalist parties, far-right rhetoric - in particular the appeal of 'heritage' populism, the levels of support for far-right nationalist parties as the scale of immigration has increased, the image of a "typical" far-right nationalist party supporter. 
Using a blended methodology, the research hypothesis was investigated. Historical research allowed an analysis of the dynamics of political organisation in Sweden and France and facilitated the identification of when and how far-right political parties appeared in the political arena. A review and analysis of the literature was completed in order to situate the study within the existing theoretical and empirical scholarship on the topic. As a result of this literature review, it was possible to identify the populist rhetoric used by far-right parties in Sweden and France to inflame concerns about immigration. Statistics were used to measure and monitor the support garnered by far-right populist parties. Particular attention was paid to periods of immigration.

The research hypothesis was shown to be correct, though some clarifications are required. The original hypothesis contended that migration served as a "trigger" not to the increase in support of far-right political parties directly, but in giving such parties the opportunity and momentum to exploit the issue of immigration. The use of various rhetorical techniques allowed far-right parties to expand the number of political and social issues deemed to be connected to increases in immigration, and enhanced the traction of nativist rhetoric regarding the well-being of the people and future generations. As it is quite difficult to connect an increase of support for the far-right with immigration, it is more feasible and realistic to analyse immigration as a trigger for far-right populist rhetoric. The issue of immigration has been exploited by the Sweden Democrats in Sweden and Front National in France.

Another key element of the hypothesis that has been proved in the course of research is the link between the migration crisis and its interpretation as a threat to the economic stability of the core population by the far-right. The far-right refers to unemployment, a decrease in GDP, crime and violence rates, depletion of resources and scarcity caused by outsiders.

The speeches of representatives of far-right parties in both Sweden and France share a common set of appeals that are incorporated into their rhetoric with slight modifications based on the specifics of the particular country. The strongest and most obvious characteristic that unites the two types of rhetoric of the countries is 'heritage' populism and all the features that it entails. Analysis of the key public speeches and rhetoric of the Sweden Democrats showed a tendency to focus on certain values/aspects of society:

1. Claims regarding the degradation of the celebrated Swedish welfare state;

2. Claims regarding the gradual take-over of Swedish ideals and imposition of Muslim values; claims regarding a threat posed to Christianity as a result of Muslim beliefs prevailing in Swedish society;

3. Claims regarding increases in violence and crime in the country (as a result of immigrants);

4. Critique of supranational powers such as the European Union.

In regards to France, the following claims have been made by a number of party members, especially Marine Le Pen herself:

1. Claims regarding the degradation of peace and order in French society;

2. Claims regarding the gradual take-over of the country by Muslims and imposition of Muslim values over the existing French values; claims regarding the threat posed to Christianity as a result of Muslim beliefs prevailing in French society; 
3. Claims regarding increases in terror attacks and a higher risks of terrorists using migrant routes to enter the country with a hidden agenda of turmoil;

4. Criticism of supranational powers, such as the European Union.

All four of the claims are constantly repeated by the parties in order to enhance their messaging regarding immigration. Apart from the above claims, members of both parties, Sweden Democrats and Front National, use a range of techniques. They create a bright visual contrast between two worlds clashing: a peaceful and stable Swedish/French way of life where equality prevails is contrasted with the violent, patriarchal world of immigrants, overridden by terror. Another stark and effective technique consists of the so-called in/out dichotomy, where "in" refers to "original" members of the society, and "out" - to non-members. Espejo and Ostiguy 's "up/down" dichotomy is also relevant. ${ }^{1}$ Sweden Democrats party members constantly refer to Social Democratic party members as elite ("up") who inflicted this horror on the nation, mentioning the fact that they themselves live in "homogenous" areas of the country, meaning - only populated by Swedes, while the working class ("down") has to live in areas in which the number of immigrants is growing. In the case of Front National, this up/down dichotomy is used more in reference to the supranational European Union governance, in which the French ("down") freedoms of legislative, territorial, administrative policies are manipulated and overtaken by those in the segment of the "up" - meaning the aloof governance of the European Union.

In both countries, all four claims can be categorised under the general "umbrella" of 'heritage' populism of the new nationalism. When rejecting the imposition of power by the European Union and their "meddling" in internal affairs, the far-right defends the "domestic heritage" of internal organisation and decision-making freedoms. Claims asserting an increase in levels of violence and crime, as well as terror attacks, highlight the heritage of peace and stability passed down by generations of blood ancestors as a result of hard toil and efforts to gain and maintain. Claims regarding the neglect of Christian morals and traditions as a result of the imposition of Islam, which is deemed "inferior" and not worthy, is nothing but referral to the preservation of religious heritage of the French and the Swedes. Finally, the most dramatic claims - the claim asserting the degradation of the celebrated Swedish welfare state and the claim asserting the degradation of peace and order in French society - are stark reminders that 'heritage' populism seeks to forge a sensation of losing something inherited and owned by right from ancestors and which has been defended and preserved by the hard toil of previous generations. The right-wing claim that the French/Swedish way of life is threatened by outsiders who have come to destroy this perfect equilibrium.

While the two countries have distinct experiences and in no way can be drawn together as a single case example, analysing both of them within the same framework of events and developments might help identify factors that are crucial in the dynamics of nationalism and support for right-wing political parties in Europe in general, the latter being such a widespread phenomenon in the $21^{\text {st }}$ century.

\footnotetext{
${ }^{1}$ P. Espejo, P. Ostiguy, The Oxford handbook of populism, Oxford University Press, Oxford 2017.
} 
Latent nationalism has existed in both countries for a relatively long period of time. In Sweden, however, the outlet of nationalist expression was an underground music culture. Even though nationalist parties did not formally enter the Parliament before 2010, their ideas flourished to a certain degree underground. In fact, Sweden became a centre of skinhead subculture and militant neo-Nazism in the 1980s and 1990s, especially in the extensive nationalist skinhead music industry. ${ }^{2}$ Though in the first decade of the $21^{\text {st }}$ century the latter had to go further underground due to a prohibition on their gatherings, when in 2010 Sweden Democrats gained representation in Parliament with their $5.7 \%$ of votes, this notorious culture was able to breathe more freely. Sweden Democrats started out as not only an anti-immigration party. Unlike other similar parties in Europe, they openly self-identified as nationalists, born in part from the skinhead movement of Nordic neo-Nazism. Hence, the official and more structured representation of nationalism was postulated in 2010 with Sweden Democrats entering Riksdag as the far-right party and securing their position with a sufficient number of votes from the people.

The situation was different in France, where history of official nationalist ideas in politics reached as far as Charles de Gaulle and presented itself in not one, but three groups of nationalists: "Orleanist" Right (non-Gaullist moderate right), "Bonapartist" Right (Gaullists), and of course of the "ultra" Right, or Far Right. ${ }^{3}$ Though the majority adopted a conservative stance on matters and official party politics, the "Ultra" or the Far-Right still adheres to its ideas and is represented by Front National. Hence for both countries a certain level of latent nationalism has existed whether it was as an underground expression (in the case of Sweden), or more vocal and public (in the case of France). One of the major differences is that in Sweden the far-right was never represented in the political arena up until 2010, but was limited to hidden subcultures, while France had a long history of right-wing parties in public office with different levels of success throughout the years.

A similarity is also traced between the dynamics of self-presenting and image construction that both parties are seen to maintain today. Sweden Democrats started out proclaiming themselves as ultra-nationalists without any disguise. The same holds true in the case of Front National under the leadership of their initial founder Jean-Marie Le Pen. The comments of the latter are at times still harsh and extremely nationalistic. What happened next for both parties was a switch to a different image - one that would be more agreeable to a general audience and subtle in terms of public acceptance. Sweden Democrats broke their ties with Alternative for Sweden whose rhetoric was much harsher and whose members, such as Gustaf Kasserlstrand, were associated with the notorious Identitarian movement. Moreover, they had to let some party members go for anti-Semitic statements. One cannot be certain in this case, but perhaps it was due to this that Sweden Democrats managed to survive in the Parliament and get the votes of the Swedes. The "break from the past" in the case of Front National was even more personal for the party leader, as Marine Le Pen

2 B. Teitelbaum, Lions of the North: Sounds of the new Nordic radical nationalism, Oxford University Press, Oxford 2017.

${ }^{3}$ A. Knapp, V. Wright, The government and politics of France, Routledge Taylor \& Francis Group, New York 2006. 
had to take over from her own father. This move demonstrated that the ideals and policies that the party is intending to present were more important than her own family relations. The so-called "de-demonization" campaign by Le Pen was a thought-through and elaborate move to appeal to the demographics that previously did not support Le Pen and her Front National, but could potentially be more accepting of the party and give them their vote. ${ }^{4}$ Hence, both parties made certain adjustments and compromises to the demands of the "normalcy" in society, made their rhetoric a bit subtler to get the popular vote and "fit in" better amidst growing criticism of their harsh and radical rhetoric.

One major conclusion that one can make from the above information is that together with the four claims and strategies used to support them, the economic situation is exploited by the far-right parties in Sweden and France to their advantage. While statistics cited by representatives of the far-right may, in some sense, be true, members of the parties do not elaborate on the details and other factors accompanying those numbers. In other instances - statements of far-right party members are not always true but phrased in a way that sounds credible and realistic. Such eloquence in referring and highlighting the economic situation, unemployment, levels of crime and violence is calibrated to exacerbate negative feelings of the public, fuelling nationalist sentiments among the people and developing the momentum for a switch from latent nationalism to virulent nationalism in both countries: Sweden and France.

\section{Bibliography}

Crepon S., Deze A., Mayer N., Marine Le Pen's challenge, "Cairo Review of Global Affairs", 22, 2016, p. 72-78.

Espejo P., Ostiguy P., The Oxford handbook of populism, Oxford University Press, Oxford 2017.

Knapp A., Wright V., The government and politics of France, Routledge Taylor \& Francis Group, New York 2006.

Teitelbaum B., Lions of the North: Sounds of the new Nordic radical nationalism, Oxford University Press, Oxford 2017.

${ }^{4}$ S. Crepon, A. Deze, N. Mayer, Marine Le Pen's challenge, "Cairo Review of Global Affairs", 22, 2016, p. 74. 
Faina Nakanechnaya

fainanakonechnaya@gmail.com

Akademia Humanistyczno-Ekonomiczna w Łodzi

\section{The meaning of borders in post-Soviet countries (Belarus and neighbouring countries) ${ }^{1}$}

\section{Introduction}

The problem of identity, including the cross-border identity of people, has become one of the central concerns of social scientists due to the collapse of the bipolar world and the emergence of organisations of regional governance. Border and regions that have borders with national states belonging to different cultures and civilisations feel the most powerful influence of the border in all respects. Cross-border cooperation, which builds its own sociocultural connections “on top of" formalised borders, exists in various forms, ranging from the simplest local border contacts to cross-border and cross-cultural interaction. Very often, cross-border cooperation occurs across international borders. Accordingly, international borders and cross-border regions are designated. The geographical position and the special status of the territory create a specific socio-economic, political and socio-cultural community. The study of cross-border regions is conducted in various aspects - in geopolitical, sociological, historical, demographic, and ecological meanings. Recently, other important components have emerged - sociocultural and historical, fixing the preservation of a cross-border region as an independent, self-sufficient phenomenon at the "junction" of interacting national cultures.

Belarus presents a concentration of various people. The Grodno region is an example of the socio-cultural transboundary nature of the Belarusian and Polish adjacent territories. The interaction of the Belarusian and Russian identity of people occurs in the Vitebsk

\footnotetext{
1 Dissertation written under the supervision of prof. dr hab. Hassan Jamsheer.
} 
region. In the Gomel region, Ukrainian and Belarusian identities predominate now. The cross-border interaction of Belarus with the neighbouring countries covers all the main spheres of the country's life. At the same time, trade and economic ties play a key role in cross-cultural cooperation, for they are most easily established between adjacent internal parts of different countries.

The foundation of transboundary interaction comprises historical traditions and experiences of interaction in the past. The current cross-border state of Belarus is, above all, an effective way to overcome many political, economic and sociocultural deadlocks left over from the Iron Curtain, distrust of the European Union by the central authorities and underestimation of the EU's role in the post-Soviet space. The cross-border region is the basis for a variety of development scenarios, due, on the one hand, to a tendency towards homogenisation and unification, on the other hand, to its heterogeneity, to the intensification of processes leading to diversity and versatility.

The existing controversy of the regional identification of Belarus, together with the state's establishment of a priority relationship with the history of the Soviet Union, makes it difficult for residents to identify themselves. Social and cultural development continues to take place in such forms that it actually divides the region into several territorial fragments, which form the cross-border "transition zones". At the same time, in Belarus there are good examples of the development of cross-border relations between neighbouring countries - these are Euroregions. However, the financial support of Belarusian projects by Russia or the European Union is of increasing importance in these regions. This affects the quality of the goals to be fulfilled and the possibilities for the development of further political and economic relations.

Transboundary issues are a condition for the formation of tolerant coexistence at the border of the national cultures of Belarus and neighbouring countries. The cross-border region is a "laboratory" of cross-cultural interaction. The problem of self-identification of people in the border areas near Belarus has not yet received sufficient scholarly attention.

\section{The cultural identity of a person in the context of transboundary region culture}

A transboundary region is defined as a potential region divided by the sovereignty of neighbouring states, possessing a complex of national, regional and zonal elements with their own characteristics, reflecting their historical and cultural identity, interacting with adjacent border regions for the preservation, management and development of their living space. Within the framework of a cross-border area, each person solves two major problems - he/she strives to preserve his/her cultural identity and at the same time joins the other. The manifestation of hybridity within a given region inevitably raises the question of where the boundary lies between the cultures that a person considers his/her own and other cultures. The answer is not as easy as it may seem at first glance. After all, the connection with our own culture is not guaranteed to anyone automatically only by virtue of blood or genes. This relationship is not established biologically and, therefore, has 
a supra-biological origin. You can be Belarusian by blood and not be culturally Belarusian, and vice versa. At the same time, the knowledge of a person in one of the cultures does not coincide with the knowledge of a person in another culture.

Since each individual can be at the same time a member of several social and cultural communities, depending on the type of group affiliation, it is customary to distinguish different types of identity: professional, civil, ethnic, political, religious, and cultural.

Of all types of identity, we are primarily interested in the cultural, which can be defined as "an individual's belonging to a culture or cultural group that forms a person's value attitude to himself/herself, other people, society and the world as a whole ${ }^{2 "}$. Thus, the essence of cultural identity lies in the conscious acceptance by the individual of relevant cultural norms and patterns of behaviour, value orientations and language, that is, in understanding one's self from the standpoint of the characteristics adopted in a given society, in self-identification with its cultural patterns.

Cultural identities connect people, but at the same time, the consciousness and individual life experience of each person isolate and separate people from each other. At the same time, a person himself/herself can change his/her identity, identifying himself/herself with one or another group, which forms the openness of social life. The openness of social life involves the choice of life ,style”, which is now becoming fundamental in the definition of cultural identity. Vadim Mezhuyev, a Russian scholar, notes that in its cultural being, a person is determined not only by external necessity, prescribing a certain cultural niche with the immutability of natural law ("just as animal and vegetable organisms are distributed by nature according to classes and types' ${ }^{3}$ ), but also by his/her freedom. The border between "our own" and other cultures is established not only by circumstances beyond our control but also by our free choice.

British scholar Stuart Hall believes that we are faced with a set of different identities. Each one appeals to us or, to a greater degree, to various parts of our Self. "The personality, like a nation-state, is experiencing the breakdown of its borders ${ }^{4}$ ". In this situation, the existence of the phenomenon of national identity becomes problematic, since the conventionally called state identity changes under the influence of globalisation. This process can lead to a power confrontation between ethnic groups, as well as to the strengthening of local identifications. Cultural "hybrids" of the trans-border area are more capable of assimilating various identities without asserting the primacy of any of them. Double standards of identification of a "hybrid" person are described by many scholars - Stonkvist, Park, Rushdie, Ganners. They all agree that hybridity is based on marginality and, therefore, at the same time is accountable to the values of different cultures. For example, in the periodic report, which was presented in Geneva

2 J. Kurysheva, The Boundaries of the Concepts of International Journalism, "Vek informatsii" (online edition) 2, no. 4(5) (2018): 57, doi:10.33941/age-info.com24 (5)2018005, 23-24.

3 V.M. Mezhuyev, The Idea of Culture. Essays on the Philosophy of Culture, "ProgressTradition", 2006, $351,13$.

${ }^{4}$ E. Scheurle, Stuart Hall (Hg.): Representation. Cultural Representations and Signifying Practices, Sage, London/Thousand Oaks/New Delhi 2012, 400 pp., "Klassiker Der Sozialwissenschaften”, 2016, 37, DOI:10.1007/978-3-658-13213-2_94, 23. 
on 1 December 2017 during the $94^{\text {th }}$ session of the Committee on the Elimination of Racial Discrimination, 112 organisations of citizens belonging to national minorities were registered in Belarus. About 140 nationalities live in Belarus. According to the 2009 census, 83.7 percent of the country's population are Belarusians, $13.9 \%$ are other nationalities, including Russians $-8.3 \%$, Poles $-3.1 \%$, Ukrainians $-1.7 \%$, Jews $-0.1 \%$. The number of representatives of other nationalities is about 70 thousand people, including 7079 people belonging to the Roma nationality 5 .

A cultural hybrid is not only a person with a wider horizon, more independent and rational views; or for example, a bicultural student, who always has a choice, achieved as a result of permanent acculturation. It is acculturation that presupposes biculturalism or multiculturalism, which is carried out as a result of the assimilation of a new culture in addition to the original one and is defined as the process of mutual influence of cultures, perception by one people, ethnic group (in whole or in part) of the culture of another. In this way, acculturation differs from assimilation, which allows for the loss of the cultural specificity of a nation or of an ethnic, religious or any other group. Acculturates are included in the bosom of another culture, complementing their primary cultural potential with new ones.

\section{The reasons of migration of people from the Belarusian territories near the border}

The $19^{\text {th }}$ century was notable for the exceptional polysemy of the sociocultural process. Wars, revolutions, social upheavals forced many to doubt the universality of reason.

Industrialisation turned the mass into "many individual creatures with the capacity to develop, but from the very beginning subordinated to another structure - the law, for which the functioning of the machine serves as a model of behaviour" ". The contradiction between the personality and the man of the masses intensified. Increasingly, people had to change their location to find a new job. That's how the process of migration began in European territory. According to the definition of the International Organization for Migration, migration is "The movement of a person or a group of persons, either across an international border, or within a State."

During the revolutions, there were several reasons for the migration of Belarusians: 1. Labour migration, 2. Migration along ethnic lines (Jewish migration), 3. Forced migration (hunger, revolutions, wars, and the search for a new place of refuge), and 4. Mixed migration. For Belarusians who live in the border areas, from the very beginning of industrialisation and revolutions, labour migration has been the main reason for changing location. Since the mid-1990s, Belarus has had moderate external migration flows.

5 “В Беларуси живут представители 140 национальностей” (Representatives of 140 nationalities live in Belarus), Новости Беларуси | Euroradio.fm, December 03, 2017, https://euroradio.fm/ru/v-belarusi-zhivutpredstaviteli-140-nacionalnostey.

${ }^{6}$ E. Deutsch, Culture and Modernity: East-West Philosophic Perspectives, University of Hawaii Press, Honolulu 1991, p. 15. 
However, despite the rather low level of emigration of Belarusians, even a relatively small negative migration balance (several thousand people per year), together with the natural population decline (decreased from 10.2 million people in 1993 to 9.5 million in 2013) and the constant growth of the demographic burden since 2008, pose a serious challenge to the country.

Migration contributes to an unfavourable change in the age structure of the population, and leads to a loss of human capital. Because of the increased temporary labour migration due to the macroeconomic crisis of 2011, a shortage of specialists arose in a number of sectors of the economy. However, temporary labour migration reduces unemployment and is a source of remittances. Since the Independence of Belarus, some states like: Russia, Poland, and Lithuania, have become increasingly attractive for Belarusians. Moreover, both Poland and Russia have recently simplified the procedures for obtaining their citizenship for certain categories of Belarusians. Poland, in particular, adopted legislation that allows holders of a "Polish card" ("Karta Polaka") to receive a permanent residence permit, and in subsequent years - Polish citizenship. According to the amendments to the Russian Law "On Citizenship", if "Belarusians or their ancestors lived in the territory of modern Russia, the territory of the RSFSR within the USSR or in the territory belonging to the Russian empire, they can apply for Russian citizenship and receive it within a few months ${ }^{7}$." Since part of the Belarusian population living in the border areas has a weak national Belarusian identity, and the Belarusian economy is no longer able to achieve high GDP growth, Belarus is threatened with an outflow of valuable human capital to neighbouring states.

The National Statistical Committee of the Republic of Belarus ${ }^{8}$ argues that, since independence, Belarus has had a positive migration balance: allegedly, more people arrived in the country for permanent residence than left. This claim is refuted by various academic studies that take into account population census data, migration, and the natural movement of the population. The data of countries that maintain clearer and more robust records indicate that the Belarusian data is inaccurate and that there has been a chronic undercount of people leaving for permanent residence, especially in Western countries.

Belarus is not a country with a positive migration balance. It is negative by more than 200 thousand people. In the last 2-3 years, Belarusian labour migrants have been reorienting from East to West. First of all - from Russia to Poland. It can be seen in the number of registered declarations of invitations for Belarusians to work - documents that employers submit to the Polish authorities. In 2014 there were only 4,000 of them, in 2016 - 23,000, and for the first half of 2017 - about 25,000. Over the past three years, there has been a rise of between eight and ten times.

7 Изменения в ФЗ о гражданстве РФ и отдельные законодательные акты (Federal Law of April 20, 2014 N 71-FZ “On Amendments to the Federal Law” On Citizenship of the Russian Federation "and Certain Legislative Acts of the Russian Federation”), “Российская газета,” April 23, 2014, https://rg.ru/2014/04/23/ grazhdanstvo-dok.html.

${ }^{8}$ Миграция населения (Migration), Национальный статистический комитет Республики Беларусь (National Statistics Committee of Belarus), 2005, http://www.belstat.gov.by/informatsiya-dlya-respondenta/ perepis-naseleniya/perepis-naseleniya-2009-goda/vyhodnye-reglamentnye-tablitsy/migratsiya-naseleniya/. 
The situation of the Russian labour market is an important factor that determines the desire of Belarusians to work in other countries. In 2018, Belarus will remain in the political and economic orbit of Russia, although the behaviour of Minsk irritates Moscow. Russia and Belarus are formally considered the closest allies (the leaders of the two countries do not get tired of talking about it). Nevertheless, there are problems in relations between Moscow and Minsk. Some Belarusian experts predict that 2018 will be conflict-free in Belarusian-Russian relations. Now Belarus buys gas at $\$ 127$ per thousand cubic meters, and in 2018 will pay $\$ 129^{9}$. This causes some dissatisfaction with officials in Minsk, who wants to receive gas at Russian domestic prices, (now the coefficient is 2.08, that is, twice as much).

Another important mobility tool is 'small border traffic' 10 . This is a type of agreement that allows residents of the border area to visit another border area of a neighbouring country without a visa. It was signed between Belarus and Latvia in 2012. Now it includes Belarus - Lithuania, and Belarus - Poland. Instead of using the tools that the European Union offers to Belarusians, the Belarusian authorities unilaterally imposed a visa-free regime for citizens of European countries in Belovezhskaya Pushcha, Grodno, and for five days for those Europeans who enter the country through the airport.

At the same time, for example, "the Belarusians abroad law ${ }^{11}$ ", only adopted in 2014, does not give Belarusian emigrants the possibility of obtaining free visas to enter the country. In the meantime, most citizens of Belarusian border cities choose Russia and Poland as markets where they can earn extra money. The typical guest worker from Belarus for many years looks similar: male, aged 26-40, who works in the transport or construction sectors. More than $80 \%$ of temporary labour migrants are men. Over the past six months, as many Belarusians have gone to work abroad as for the whole of 2014 . According to statistics from the Department of Citizenship and Migration, since 2010 the number of such migrants has doubled. In 2017, over 80,000 Belarusians temporarily worked abroad. A year earlier - about 60,000, and in 2015 - almost 40,000. In addition, every year hundreds of thousands of people, who are not taken into account by official statistics, leave Belarus for work. A study by the Warsaw think tank EAST ${ }^{12}$ shows that even though the Russian labour market is still in the lead, Poland is increasingly attractive to Belarusian migrant workers.

Recently, more and more Belarusian workers are looking to the EU labour market. The social networks (already working friends, relatives) are not as developed as they are in Russia. Moreover, searching the Internet is more difficult for language reasons. Because of

9 "Information Based on the Interactive Information Analytical System for Distribution of Official Statistical Data”, Национальный статистический комитет Республики Беларусь (National Statistics Committee of Belarus), April/May 2019, http://dataportal.belstat.gov.by/AggregatedDb.

10 “Small Border Traffic (Малое приграничное движение)”, Малое приграничное движение - Migrant RU, http://www.migrant.info.pl/Малое_приграничное_движение.html.

11 "Ministry of Foreign Affairs of the Republic of Belarus for Belarusians Abroad, Law of the Republic of Belarus of June 16, 2014 No. 162-Z “On Belarusians Abroad”," Белорусы зарубежья - Министерство иностранных дел Республики Беларусь, September 2014, http://mfa.gov.by/mulateral/diaspora/.

12 A. Yeliseyeu, Migration between Belarus and Poland: Current Trends and Prospects, Eurasian States in Transition, March 2018, 1-15. 
that more Belarusians began to apply for work in Poland and other EU countries through employment companies. The interest in Poland was also influenced by the simplified procedure of employment when a work permit is not required for workers up to 6 months. It is enough to have an invitation and a working visa or the 'Polish card'.

According to the forecasts of an international research project implemented in 2013 2014: "By 2050, from 380 to 600 thousand Belarusians will live in the European Union ${ }^{13}$." That is the number of residence permits in the EU, excluding temporary labour migrants who can work not on the basis of a residence permit, but on the basis of a seasonal work visa. Consequently, with a high degree of probability, this is the number of Belarusians who will irrevocably leave the country and move to the EU. An interesting situation is emerging in the countries of Central Europe. Natives from Poland, Slovakia and other countries return from Western Europe to their homeland after 10-15 years of emigration. They bring the skills they have gained in the West. This can happen with Belarusian migrants if Belarus becomes more promising and attractive for them in the future. In the meantime, there are good opportunities in comparison with abroad, except in the IT sphere and related industries. It is less likely that Belarusians, who want to be involved in that industry, will return to their homeland. Firstly, the industry itself is going through difficult times, and secondly, it is difficult to achieve success where you have to compete with state-owned enterprises in Belarus. The situation in science and medicine is almost as difficult for good specialists. Representatives of these industries are faced with a choice to work at home for a small salary and modest prospects or to leave to earn money in developed countries. For example, in 1996-2010, "scientists and university professors left Belarus on a mass scale. They moved mainly to Germany, Russia, the United States and Israel ${ }^{14}$." From 2001 to 2013, the organisations of the Academy of Sciences lost 109 researchers who are now working in the USA, Canada, and the EU countries. Half of them had a degree. It is possible to keep Belarusians in their native country by carrying out reforms in the social sphere, education and the labour market, which will lead to an increase in the quality of life of the population.

Decent job opportunities will be an incentive to return for those who have moved abroad for the sake of career growth, good earnings, and opportunities to realise their potential.

\section{Conclusions}

The border, being a sociocultural project of state building, in modern conditions stimulates the creation of new cross-border structures and a new identity in the border areas. The paradox of the border of a cross-border region is manifested in the "duality" of this

${ }^{13}$ Migration Forecast Between the EU, the Visegrad Four Countries and Eastern Europe: Implications for the Abolition of Visa Requirements (Прогноз міграції між СС, країнами Вишеградської четвірки та Східною Свропою: наслідки скасування візового режиму), June 2014, 1-21.

${ }_{14}$ M. Artyukhin, Белорусская наука в условиях модернизации: соичиологический анализ (Belarusian Science in Terms of Modernization: A Sociological Analysis, National Academy of Sciences of Belarus), National Academy of Sciences of Belarus, Minsk 2015, 1-15. 
construct: on the one hand, the cross-border region is a mental construction with difficultto-define dynamic borders destroying the usual concept of "state-nation-territory". On the other hand, a cross-border region is a historical-geographical or political-administrative reality, marked by a state border. The border identity nature of the geographic location of the cross-border region in cultural development acquires the semantics of life "at the border". The localisation of globalisation processes within the sociocultural space of Belarus in modern times has led to an increase in the role of state borders between Belarus and neighbouring states (Russia, Poland, Ukraine, Lithuania), resulting in the strengthening of sociocultural ties ,,across" national borders, leading to the formation of cross-border regional structures, integration of interacting cultures in the local space. Representing the sociocultural unity of regional border cultures, a cross-border region, as an open type system, has a complex structure and a multiplicity of connections between its parts, which determines its originality and uniqueness, and which is explained in terms of homeostasis and self-reference.

Cross-border identity marks the territorial „otherness” of the border area itself and is understood as the ,identity" of a part of the border area. Those at the crossroads of two or more worlds at the same time have the following characteristics: emergence, polymorphism, tolerance, lability, "cultural hybridity", biculturalism, self-awareness and selfidentification, transit, that is, the ability to transfer experience between cultures, thereby sifting information through coarse or subtle "sieves" of acceptance and opposition from recipient cultures. The essence of a cross-border region lies in the disappearance of the rigid structuring of a regional "society" into "groups" with single and defined "life worlds" and in the formation of a multidimensional differentiated social reality with conditional and blurred intergroup boundaries.

Cross-border identity does not contradict the Belarusian national and regional identity. On the contrary, it plays the role of a double counterbalance: on the one hand, it coexists with a stable national identity, on the other - it creates „border” on the local territory, expanding regional identity. Cross-border identity marks the connection that a resident of a particular region feels to his place of life, and forms a "border person" determined by the features of a natural landscape, historical, social, industrial, economic, and sociocultural development of a specific territory.

What options for a new social contract in Belarus are the most realistic?

Option one - slow reforms to improve the quality of social services and increase the satisfaction and loyalty of the population. This option implies a very slow and cautious transformation of public life at the local level, without any changes at the central political level, as well as the abolition of the ,vertical of power”. The core of the reforms could be the creation of mechanisms for civic participation and feedback from the population, which would provide the central and local levels of government with relevant information on the needs of citizens and the quality of state social services on the ground. Such tools could be: civic participation budgets and grants from local authorities, social ser- 
vices outsourcing; local referendums, public debates, electronic petitions with special status - in general, everything that allows people to let off steam and participate in local decision-making, and the authorities quickly responding to rising social tensions without clubs and tanks.

Option two - inertial. This option implies the absence of real improvement in the quality of state social services, with the continuation of the propaganda campaign "State for the People" and broadcasts of the show "public separation of officials by the President" through state media. This option is dangerous for the current president's state by critically reducing the support and trust of the people. State dissatisfaction will increasingly have to be suppressed by force and targeted concessions. Citizens, in turn, will respond with an increase in labour migration. There will be an increase of the role of family, friends and the community. Civil society organisations and activists will become alternative sources of social support in a difficult life situation. The second scenario is most likely - the current president has repeatedly expressed a negative opinion about reforms. This means that the current government in Belarus will slowly die and give way to civil society.

\section{Bibliography (transcripted)}

Artyukhin M., Belorusskaya nauka v usloviyakh modernizatsii: sotsiologicheskiy analiz (Belarusian Science in Terms of Modernization: A Sociological Analysis, National Academy of Sciences of Belarus), National Academy of Sciences of Belarus, Minsk 2015.

Deutsch E., Culture and Modernity: East-West Philosophic Perspectives, University of Hawaii Press, Honolulu 1991.

„Information Based on the Interactive Information Analytical System for Distribution of Official Statistical Data". Natsional'nyy statisticheskiy komitet Respubliki Belarus' (National Statistics Committee of Belarus), April/May 2019, http://dataportal.belstat.gov.by/AggregatedDb [access: 15.05.2019].

Izmeneniya $v$ FZ o grazhdanstve RF i otdel'nyye zakonodatel'nyye akty (Federal Law of April 20, 2014 N 71-FZ „On Amendments to the Federal Law” On Citizenship of the Russian Federation and Certain Legislative Acts of the Russian Federation”), „Rossiyskaya gazeta”, April 23, 2014, https://rg.ru/2014/04/23/grazhdanstvo-dok.html [access: 15.05.2019].

Key Migration Terms, International Organization for Migration, March 16, 2016, https://www. iom.int/key-migration-terms [access: 15.05.2019].

Kurysheva J., The Boundaries of the Concepts of International Journalism, "Vek informatsii" (online edition) 2, no. 4(5) (2018). DOI:10.33941/age-info.com24(5)2018005.

Mezhuyev N.M., The Idea of Culture. Essays on the Philosophy of Culture, ProgressTradition, 2006, 351-408.

Migration Forecast Between the EU, the Visegrad Four Countries and Eastern Europe: Implications for the Abolition of Visa Requirements (Prohnoz mihratsiyi mizh YES, krayinamy Vyshehrads'koyi chetvirky ta Skhidnoyu Yevropoyu: naslidky skasuvannya vizovoho rezhymu), June 2014, 1-184, Centre for Eastern Studies, Warsaw 2014.

Migratsiya naseleniya [Migration], Natsional'nyy statisticheskiy komitet Respubliki Belarus' [National Statistics Committee of Belarus] 2005, http://www.belstat.gov.by/informatsiya- 
dlya-respondenta/perepis-naseleniya/perepis-naseleniya-2009-goda/vyhodnye-reglamentnyetablitsy/migratsiya-naseleniya/ [access: 15.05.2019].

Ministry of Foreign Affairs of the Republic of Belarus for Belarusians Abroad, "Law of the Republic of Belarus" of June 16, 2014, No. 162-Z "On Belarusians Abroad", Belorusy zarubezh'ya-Ministerstvo inostrannykh del Respubliki Belarus', September 2014, http://mfa. gov.by/mulateral/diaspora/ [access: 15.05.2019].

Scheurle E., Stuart Hall (Hg.): Representation. Cultural Representations and Signifying Practices, Sage: London/Thousand Oaks/New Delhi 2012 [erschienen 1997], 400 S. Klassiker Der Sozialwissenschaften, 2016, 404-07. DOI:10.1007/978-3-658-13213-2_94.

Small Border Traffic (Maloye prigranichnoye dvizheniye), Migrant RU, 2019, http://www. migrant.info.pl/Малое приграничное_движение.html [access: 15.05.2019].

Yeliseyeu A., Migration between Belarus and Poland: Current Trends and Prospects, Eurasian States in Transition, March 2018, 1-13. 


\title{
Sonia Rojeska
}

\author{
sonia.rojeska@gmail.com
}

Akademia Humanistyczno-Ekonomiczna w Łodzi

\section{Gender imbalance in the political landscape and mainstream media discourse in Poland ${ }^{1}$}

The issues addressed in the dissertation Gender imbalance in the political landscape and mainstream media discourse in Poland are summarised in this paper. In order to discuss the problem of gender inequality, attention was focused on communities dealing with the issue. The dissertation also considered the history of Poland. The writing of the dissertation coincided with several events that were significant for Polish citizens. On 21 October 2018 (and 4 November 2018 (the $2^{\text {nd }}$ round)), Polish local self-government elections were held. The relatively young Polish democracy, which introduced local self-governments, can be dated to the political changes after 1989. Since then, political participation in Poland has been increasing very slowly to slightly over $50 \%$ in the local elections in 2018 .

On 26 May 2019 people of member states of the European Union voted in the European Parliament elections. It was the fourth time Polish citizens had voted in this election since Poland became a member of the European Union in 2004. A woman was ranked first on the list of candidates who accumulated the most votes in those elections. Former PiS (Law and Justice) government prime minister Beata Szydło gained over half a million votes.

On 11 November 2018 Poles celebrated the $100^{\text {th }}$ anniversary of Poland regaining independence. Along with reclaiming independence, Poles obtained electoral votes. For the first time both Polish men and women could vote. The Second Polish Republic was one of the first countries in the world that granted women electoral rights. In the elections to the Legislative Sejm, whose $100^{\text {th }}$ anniversary was celebrated last year, seven women were elected deputies: Gabriela Balicka-Iwanowska, Jadwiga Dziubińska, Irena

\footnotetext{
${ }^{1}$ Dissertation written under the supervision of dr hab. Edyta Pietrzak, prof. PŁ.
} 
Kosmowska, Maria Moczydłowska, Zofia Moraczewska, Zofia Sokolnicka and Franciszka Wilczkowiakowa. Officially, the history of women in politics in Poland begins with the regaining of independence and Poland appearing again on the map of Europe. In fact, women's activism in the field of politics arose earlier with the female press and multiple female self-organisations. The names of women, their ideals, attitudes and aspirations, which contributed to shaping Polish realities at the beginning of the $20^{\text {th }}$ century, are almost forgotten today, which is undeniably symptomatic of current gender biases.

The dissertation reviews the situation of women in politics 100 years after gaining the franchise in Poland in 1918. The theoretical problem addressed in the dissertation is how the portrayal of female representation in popular news media impacts on the contemporary political landscape in Poland in relation to gender balance and power distribution. Critical analysis of media discourse has been performed on sample texts which appeared on four most influential online news platforms in Poland. Special focus is paid to how media discourse may reinforce the power imbalance.

The aim of the thesis is not only to investigate the current Polish political scene, but also to propose how political institutions and social practices could possibly be rearranged in order to give women more space in the political arena. The dissertation:

- presents some influential but almost forgotten Polish female politicians (herstory)

- examines the current state of the political landscape in Poland as well as globally

- investigates media discourse in Poland.

The dissertation shows how women lead differently than their male counterparts as politicians, educators and social activists, and highlights challenges they face because of their gender. The main assumption of the dissertation is that bridging the gender gap in political leadership would add new values to politics in general and to the politics in Poland in particular. To put it simply: more women in politics means that the varied interests of voters are represented more evenly.

\section{Feminist political theory}

Feminist political theory covers a wide range of approaches. It overlaps with related areas, including legislation, philosophy, empirical research in political science and feminist research methods applied in political science.

As stated by Watson ${ }^{2}$, what distinguishes feminist political theory from feminism in general terms is the specific examination of the state and its role in reproducing or correcting gender inequality. As most feminist theories, feminist political theory demonstrates relations of power present in our daily lives. Thereupon feminist theory taken as a whole can be described as a political philosophy. The field of feminist political theory is not only broad and multidisciplinary, it is also relatively new. The terms feminist political theory and feminist political philosophy correspond and can be used interchangeably. The Stanford

2 L. Watson, Feminist Political Theory, [in:] International Encyclopedia of Ethics, Blackwell Publishing Ltd, Oxford 2013. 
Encyclopedia of Philosophy uses the term feminist political philosophy and explains it as a field for the development of new ideals and practices in political and social institutions.

Feminist political philosophy is an area of philosophy that focuses on understanding and criticising common political philosophy and how it is systematically constructed. It unveils the deficiency and inadequacy of the traditional approach, which overlooks women. Feminist political philosophy draws attention to feminist concerns and articulates how political theory may be reconstructed in a way that advances them. Feminist political philosophy can be described as a branch of both feminist philosophy and political philosophy. As a branch of feminist philosophy, it serves as a form of critique. It investigates the political world and uncovers the ways in which women and women's current and historical concerns are poorly depicted, represented and addressed. As a branch of political philosophy, feminist political philosophy creates ground for developing new ideals and practices for how political institutions and tools should be reconstructed and reorganised. Feminist political philosophy can be described as the paradigmatic branch of feminist philosophy. It best illustrates the meaning of feminist theory, which is, to change the existent order. While feminist philosophy has already criticised and reconstructed many areas of philosophy, from aesthetics to the philosophy of science, feminist political philosophy focuses broadly on understanding ways in which collective life can be improved. First, it has to be understood how power emerges and how it is used or misused in public life. ${ }^{3}$

\section{Reality shaping power of the media}

In the introduction to Medien-Welten Wirklichkeiten Gianni Vattimo and Wolfgang Welsch ${ }^{4}$ argue that 'In the last century, the role of the media has been transformed from an element delivering reality (Wirklichkeitsvermittlung) into a factor imprinting its mark on this reality (Wirklichkeitsprägung)'. The main goal of the dissertation's chapter on the media is to show that the media are a powerful tool that influences opinions and attitudes, and shapes society. In the literature on the subject one can find divergent views: exaggerating the impact of mass media on the recipient, as well as completely denying them such powers. The author acknowledges the potential of the message delivered by the media, the message which is present despite or because of being unspoken (das Unsagbare) and which can, and does, shape the understanding of the modern world. The activity of media, understood as an information transporting network of a vast range, certainly constitutes an element that co-creates how we understand the world.

Most people are convinced of their absolute freedom of making decisions in everyday life. They live convinced of the independence of their opinions, knowledge and beliefs. While refusing to admit that they may be affected by mass media (news, advertisements), they tend to think that the media may have more influence on others than on themselves. ${ }^{5}$

${ }^{3}$ N. McAfee, K.B. Howard, Feminist Political Philosophy, [in:] E.N. Zalta (ed.), The Stanford Encyclopedia of Philosophy, https://plato.stanford.edu/archives/win2018/entries/feminism-political.

${ }^{4}$ G. Vattimo, W. Welsch (Hg.), Medien-Welten, Wirklichkeiten, Fink, München 1998.

5 D. Doliński, Psychologiczne mechanizmy reklamy, GWP, Gdańsk 2003, p. 13. 
Meanwhile, the issue of the impact of mass communication media on the recipient, or more precisely - the effects they induce, has begun to gain more and more space in the field of communication research. Almost all research on knowledge about mass communication concerns the issue of the impact of mass media on the recipient. This issue stays in focus not only to media researchers, but also to those who create these media. Knowledge in the field of mass communication serves practitioners in many spheres of social life, such as political, social or advertising communication.

Information and communication technologies play an increasing role in the modern world, facilitating the transmission of information on a gigantic scale. The Internet, carrying a vast range of information resources and services, electronic mail, telephony, etc., has become an inherent part of the everyday life of billions of people around the world. Portable devices such as smartphones allow people to dive into the information network anywhere, anytime. Paying attention to dynamic changes in people's needs and behaviour, the press and television industry is gradually moving to the Internet. The media's ability to shape views and, for instance, political choices is expanding thanks to the medium that allows people to be 'constantly informed'. In the modern world, online media are there shaping opinions, attitudes, ideas, decisions, co-creating the human beings of the $21^{\text {st }}$ century. Given the growing role that the online press and social media play in everyday life, they should be acknowledged as powerful tools to induce social changes.

\section{Women in media}

According to the Council of Europe, women in the EU represent only about $25 \%$ of the people visible in the news - read about, heard or seen in the media. Women's low visibility, both qualitative and quantitative, manifests itself in sexist media content, rare use of women as experts and the relative absence of women's viewpoints and opinions in the media. Globally, women journalists and media professionals are often being excluded from more prestigious topics, they are five times less rewarded for their work achievements, and their occupation of senior positions within media organisations is minimal. Women, as media professionals, often encounter pay inequalities and precarious conditions of employment. According to the Global Media Monitoring Report in 2015, women made up only one in four media decisionmakers, one in three reporters and one in five experts interviewed. Under-representation of women in decision making in this sector contributes to the choice of topics and the way they are presented. Inequalities in society are reproduced in the media. Media content very often reinforces stereotypes and attitudes contributing to discrimination and violence against women.

\section{Conclusion}

The main questions of the dissertation were: Is gender inequality present in politics in contemporary Poland? Is the media discourse to some extent responsible for preventing women from entering the world of politics? Finally, should modern society aim to introduce more women into politics? 
The purpose of the research was to identify gender inequality in the political landscape in Poland. It revealed the gendered imbalance of power in popular Polish news media. By analysing the factual presence of women in politics in Poland 100 years ago and today, as well as their presence in the news media at the turn of 2017/2018, the dissertation showed that women do not benefit from quantitatively equal representation either in politics or in the media. Those outcomes were interrelated, since lower representation in politics translates to lower visibility in news media. Nevertheless, the results of critical analysis of the media discourse delivered in the dissertation indicated this relation can be reverted. The assumption, which arose from the research, is that qualitatively lower presentation of women in the media may indirectly influence women's decisions regarding the choice of career path. Despite the prevailing recognition of the central role of media in shaping society's perceptions, attitudes and behaviour, this assumption has not been sufficiently justified within this research.

In the qualitative analysis of the news media discourse in Poland carried out for the purpose of the dissertation, the following social problems were stated:

- media content overwhelmingly focuses on soft news, which includes information about female politicians' personal characteristics or private life instead of their political positions;

- women's appearance is the subject of public discussion;

- women holding public office are very often compared to somebody, first and foremost - to Margaret Thatcher;

- great focus is laid on women being mistaken in their public communication e.g. in social media

- a popular topic of news content is conflict between women, their reactions to that conflict and its outcome.

The findings confirm that gender inequality is reflected in the way women are presented in the news. This research clearly illustrates gender bias being transported by language and reproduced by the media, but it also raises the question of the impact of this phenomenon on women in Poland.

To answer the latter question regarding justification for greater inclusion of women in politics in Poland: gender balance in politics is not only needed but also constitutes an inevitable element of modern democracy. Since society and legislation (seen as powers) agreed to guarantee all citizens electoral rights - both active and passive - women, just as men, are allowed to participate in political life as much by choosing their delegates as by representing their voters. It is credible to assume that women in politics broaden the representation of the diverse interests of voters by addressing issues and needs they can relate to. Moreover, according to the research, women are often equipped with a different voice (Gilligan, 1982). Women introduce a different approach to problem-solving, decision-making, prioritisation of issues, to name only a few aspects, if they dare to speak up. Some believe it was much more difficult a hundred years ago than it is now. Nothing could be more wrong. The process of cultural shift takes much more time than does a legislative change. The gender equality women aim for today means equal visibility, acknowledgement, participation and responsibility of both women and men in all spheres of public life. Gender balance is one of the indicators of gender equality, prerequisite for 
achievement of social justice. Aiming for diversity in media content is essential for fostering the instruments of democracy, such as public debate and political pluralism. Bridging the gender gap is not of interest to women only, but it concerns society as a whole. Democratic governance and sound decision-making requires the equal participation of women and men in society. This is an essential condition if politics are to reflect the reality of citizens in all their diversity.

\section{Bibliography}

Doliński D., Psychologiczne mechanizmy reklamy, GWP, Gdańsk 2003.

McAfee N., Howard K.B., Feminist Political Philosophy, [in:] E.N. Zalta (ed.), The Stanford Encyclopedia of Philosophy (Winter 2018 Edition), https://plato.stanford.edu/archives/ win2018/entries/feminism-political [access: 03.03.2019].

Vattimo G., Welsch W. (Hg.), Medien-Welten, Wirklichkeiten, Fink, München 1998.

Watson L. Feminist Political Theory, [in:] International Encyclopedia of Ethics, Blackwell Publishing Ltd, Oxford 2013. 
Magdalena Wojtas

mwojtas@plgbc.org.pl

Akademia Humanistyczno-Ekonomiczna w Łodzi

\title{
Aspects of the European Union's climate policy in the context of the opportunities offered by the building sector - innovation in action ${ }^{1}$
}

\begin{abstract}
The European Commission wants Europe to become climate-neutral by 2050 .
28 November 2018. The Commission has set out a long-term strategic vision for a prosperous, modern, competitive and, above all, climate-neutral economy by 2050, showing how Europe can lead the way in achieving this goal by investing in realistic technologies, empowering citizens and adapting policies in such areas like industrial policy, finance and research. In this transition process, social justice must also be guaranteed.

The Commission's vision for a climate-neutral future, following the suggestions of the European Parliament and the European Council, covers almost all EU policies and is in line with the Paris Agreement objective of keeping the temperature increase well below $2^{\circ} \mathrm{C}$ and trying to bring it down to $1.5^{\circ} \mathrm{C}$.

The Commission adopted its strategic vision on 28 November 2018 in advance of the UN Climate Summit (COP24), which took place from 2 to 14 December in Katowice. Clean technologies are opening up new opportunities for industry and investors, even if capital markets are slower to adapt to the climate economy. Renewable technologies such as solar, hydro or wind energy are expected to enable the EU to reduce its greenhouse gas emissions by up to $90 \%$ by $2050^{2}$.
\end{abstract}

Most of us often underestimate how important buildings are to us. They are where we spend most of our time, they are the consumers of the largest amount of energy. It is also buildings that are largely responsible for our unsustainable material management, air pollution and water consumption. At present, according to European Commission statistics,

\footnotetext{
${ }^{1}$ Dissertation written under the supervision of Dr hab. Edyta Pietrzak, prof. PŁ.

${ }^{2} \operatorname{COM}(2018) 773$.
} 
buildings in the European Union consume as much as $40 \%$ of the energy produced and are responsible for around $35 \%$ of greenhouse gas emissions. Poland, as a member of the EU, is obliged under the EPBD 2010/31/EU Directive to ensure that from $1^{\text {st }}$ January 2019 all new buildings occupied and owned by public authorities are nearly zero-energy buildings. In two years' time this obligation will extend to all new buildings in the country ${ }^{3}$. Improving the status of existing buildings and rules for creating new ones are a priority in the fight against climate change. Only $1 \%$ of buildings in the EU are currently renovated every year, so it is impossible to create the zero-emission buildings necessary to prevent a climate catastrophe unless countries intensify their efforts. Greater ambition in these actions would help to reduce health inequalities and contribute to reducing energy poverty for around 50 million Europeans ${ }^{4}$.

\section{EU climate policy at the service of humanity}

The attitude of the governments of the European Union Member States towards the fight against global climate change is largely determined by internal political factors. This is due to the constant competition for positions and power in the political system. Thus, the support of a given government depends on meeting the expectations and requirements of its recipients. The analysis of these factors leads politicians to decide whether to implement low-carbon models or, on the other hand, to disregard climate factors (so-called business as usual). It is also possible to adopt attitudes which, in consequence, will lead to increased emissions. The lack of continuity in the strategy chosen by successive governments is an example that the same economic and social reality can be interpreted in an extreme way. The problem of climate change is therefore a political issue.

Discussion and, as a consequence, concrete steps in climate policy are tasks which outweigh many existing sectoral policies in terms of complexity. Above all, the main challenge is to identify the problem and to convince the public to take concrete action. Global climate change is overwhelming and existential, but also elusive and remote. It is not clear to many citizens why there is already an urgent need for radical action if the symptoms of the crisis are not visible. In particular, societies undergoing economic transformation, as well as those not radically affected by climate change, may raise questions for politicians about the legitimacy of implementing climate policy. The government is therefore obliged to use its institutional and informational potential for social dialogue and thus to put the problem on the political agenda, which is an expression of three elements: national sentiments, positions, organised political forces and administrative and legislative liquidity ${ }^{5}$.

\footnotetext{
3 Zielone budownictwo a rola samorzadu, https://www.przestrzen-miejska.pl/artykul/zielone-budownictwoa-rola-samorzadu [access: 12.05.2019].

${ }^{4}$ Zdrowe budynki, zdrowsi ludzie, https://www.env-health.org/wp-content/uploads/2018/05/HealthyBuildings- pl-V1-1.pdf [access: 12.05.2019].

5 J. Hovi, D. F. Sprinz, A. Underdal, Implementing Long-Term Climate Policy: Time Inconsistency, Domestic Politics, International Anarchy, "Global Environmental Politics”, Volume 9, Number 3, August 2009, p. 20.
} 
Climate policy is a relatively new policy which is only just setting its place in the hierarchy of priorities and needs the support of many decision-makers both within and around the political system. If the government decides to start fighting $\mathrm{CO}_{2}$ emissions, it should be prepared to rebuild other political strategies or even the whole economic model of the state. The fight against global warming and climate change modifies at least a dozen or so fields, among them: energy policy, transport and agriculture, to name but a few. It calls for the choice of new technologies, innovative thinking and the introduction of 'good practices' in both the public and private sectors. It also has a significant impact on the construction sector, which in reality determines the condition of the whole economy, thereby specific regulations may determine the condition of the whole sector.

The new model requires institutional and bureaucratic strength from the state. Governance should focus on increasing energy efficiency, introducing incentives for green investments and technologies, modernisation of energy-intensive industries. Jeffrey Sachs, who helped to reform the Polish economy in the early 1990s in the spirit of liberal free market reforms, expressed the view that the dimension of contemporary threats requires an active role of the state ${ }^{6}$. It is up to the State to correct market forces in order to reduce the conflict between public and private interests, particularly in terms of natural resources and interference with the environment. The problem is not, according to Sachs, their exhaustion. The problem is that the markets are unable to bring about their wise, sustainable use.

The model described above has a significant chance of being implemented in highly developed countries because climate protection issues have been included in the political agenda of the vast majority of groups ${ }^{7}$.

\section{Energy and climate - horizon 2030. Scenarios for the world and Europe}

2030 is the next step towards building a competitive and low-carbon European economy by the middle of the $21^{\text {st }}$ century. To reach the global target of a $40 \%$ reduction in greenhouse gas emissions, the sectors covered by the EU ETS will need to reduce their emissions by $43 \%$ compared to 2005 . Emissions from non-ETS sectors will need to be cut by $30 \%$ below 2005 levels. These EU-wide targets must be translated into Member States' targets. In October 2014 the European Council set out the main principles to achieve the targets ${ }^{8}$.

Activities should develop models, tools, decision support systems, methodologies, strategies, guidelines, standards and approaches for the design, construction, implementation and monitoring of nature-based solutions and reconstruction, prevention of further degradation, remediation and maintenance of urban and peri-urban ecosystems and ecological coherence and integrity of cities. Actions should include reviewing and building

\footnotetext{
6 J. Sachs, Nasze wspólne bogactwo. Ekonomia dla przeludnionej planety, Warszawa 2009, p. 110.

7 D. Cameron, The Low Carbon Economy Security, Stability And Green Growth, The Conservative Party, "Protecting Security Policy Green Paper" 2010, No. 8, p. 3.

8 Effort sharing: Member States “ emission targets, https://ec.europa.eu/clima/policies/effort en [access: 21.04.2019].
} 
on existing experience and good practice in Europe. Strategies and tools should be part of integrated and ecologically coherent land-use planning and urban development processes that would ensure fair and equitable distribution of the benefits of restored urban ecology and reduce its exposure to environmental pressures ${ }^{9}$.

It is estimated that by 2050 up to $70 \%$ of the world's population will live in urban areas. Urbanisation affects human health and well-being through factors such as exposure to pollution, including noise, disasters, stress and disease, physical inactivity, degraded ecosystems and the erosion of natural capital, which may deteriorate as a result of climate change ${ }^{10}$. As recognised in the new Habitat III Urban Agenda, public space plays a key role in the interaction between cities and systemic innovation in cities. Public spaces, through sustainable design and management, should ensure that the way in which citizens interact within the urban fabric increases resilience to climate change, thereby reducing the environmental impact of cities ${ }^{11}$.

\section{Green growth and circular economy}

The further development of a sustainable, resource-efficient and competitive economy will require a shift towards a more circular economic model, including products, processes, services and business models that aim to maintain the value and usability of materials and resources in the economy for as long as possible. Economic solutions should combine strong environmental rationale with convincing business logic. The actions aim at significant improvement of resource efficiency in the medium term (including energy and water), minimisation of waste production and an increase in the use of secondary resources, while avoiding negative health impacts, and at a reduction of pollution and greenhouse gas emissions. They aim to clarify the role of design in the sustainability of products, to increase the capacity of cities to adopt circular economy and to support the transition to systemic, integrated solutions that close resource use cycles in the water sector. They will contribute to the implementation of the circular action plan and key EU high-level priorities, including employment, growth and investment, climate and energy, and strengthening the industrial base. Ultimately, they are expected to support Europe's efforts to achieve the objectives of sustainable development (SDG).

A greener economy means new economic growth and new employment opportunities. Eco-design, eco-innovation, waste prevention and the re-use of raw materials can bring net savings of up to $€ 600$ billion for EU companies ${ }^{12}$. Additional measures increasing resource efficiency by $30 \%$ by 2030 could increase GDP by almost $1 \%$ while creating

\footnotetext{
9 COM (2012)497.

${ }^{10}$ COM (2012)710. Proposal for a Decision of the European Parliament and of the Council on a General Union Environment Action Programme to 2020 „Living well, within the limits of our planet”.

11 The New Urban Agenda, http://habitat3.org/wp-content/uploads/NUA-English.pdf [access: 21.04.2019].

12 Guide to resource efficiency in manufacturing: Experiences from improving resource efficiency in manufacturing companies, Europe INNOVA 2012.
} 
millions of additional jobs. It is also beneficial for the environment and reduces Europe's greenhouse gas emissions ${ }^{13}$.

There is a clear need for cities to become circular cities in order to change urban consumption patterns and value chains, and to stimulate innovation, business opportunities and job creation in both existing and newly created sectors ${ }^{14}$.

\section{Eco-innovation}

The planet's population is growing by 140,000 people per day, leading to pressures on resources and to environmental challenges. To achieve sustainable green growth and remain competitive, we must make greater use of every tonne of material, every hectare of land and every joule of energy. Investing in eco-innovation is essential to give Europe global leadership in creating a resource-efficient society.

Eco-innovation can help create new business opportunities, jobs and growth in Europe. It is estimated that this eco-innovation sector currently has an annual turnover of $€ 227$ billion, or around $2.2 \%$ of EU gross domestic product, which is more than Europe's aerospace or pharmaceutical industry. The Commission has developed an Eco-innovation Action Plan (EcoAP), which supports a wide range of eco-innovative processes, products and services, and includes a pilot programme to help market penetration of cutting-edge green technologies - providing external expert verification of performance and technology benefits. The EU Environmental Technologies Verification (ETV) pilot scheme can be especially useful for small and medium-sized enterprises (SMEs) ${ }^{15}$.

\section{Implementing Sustainable Development Goals - new challenges}

In September 2000, world leaders adopted the United Nations Millennium Declaration, which was the basis for achieving the Millennium Development Goals. A global consensus was reached on the importance of poverty reduction and social development. Nevertheless, the results do not meet international expectations and global targets to be achieved by 2015 . Continuing with current strategies is not sufficient to achieve sustainable development after 2015 .

In recent years global sustainability challenges have been driven by a wide range of 'megatrends', such as changing demographic profiles, changing economic and social dynamics, technological progress and lack of prevention of environmental degradation. There is a need for a better understanding of the links between these trends and the related changes in economic, social and environmental conditions.

13 Towards the Circular Economy: Economic and business rationale for an accelerated transition, Ellen MacArthur Foundation, 2012.

14 Circular Economy Action Plan COM(2015) 614 final.

15 Eco-innovation Action Plan, https:/ec.europa.eu/environment/ecoap/frontpage en [access: 23.04.2019]. 
While the Millennium Development Goals focused on selected priorities of social and human development, today's world is full of new challenges, compounded by numerous financial, economic, food and energy crises. These challenges threaten the ability of individual countries to achieve sustainable development. The United Nations Conference on Sustainable Development reaffirmed the need for the political commitment of the international community to sustainable development, in line with the principles of Agenda 21, including the principle of shared but differentiated responsibilities ${ }^{16}$.

The outcome document of the United Nations Conference on Sustainable Development provides guidance for achieving the transition to sustainable development as a means of enhancing the well-being of current and future generations in all countries. Sustainable development strategies must integrate and take particular account of the needs of the poorest and most vulnerable groups in society. Strategies must be ambitious, action-oriented and collaborative, taking into account different national circumstances. They will have to systematically change patterns of consumption or production and may, inter alia, involve significant price adjustments, encourage the conservation of natural resources, reduce inequalities and strengthen economic governance ${ }^{17}$.

Since 2007, more than half of the world's population has lived in urban centres and it is estimated that by 2050 this percentage will exceed 70 per cent. Eighty per cent of the world's urban population will live in developing regions, especially in African and Asian cities. In many developing countries, rapid urban development requires additional resources, and the development of local government capacity has become a pressing issue. It should also be noted that urban areas are constantly evolving as a result of human mobility, population growth, socio-economic development, environmental changes and local and national policies ${ }^{18}$.

\section{Conclusion}

Green building is a solution to mitigate negative climate change. Energy-efficient construction of new buildings and renovation of existing buildings can reduce energy consumption for space and water heating in buildings by $40-50 \%$. However, if current inefficient building practices persist, buildings could account for $70 \%$ of $\mathrm{CO}_{2}$ emissions by 2050 .

According to NASA, 16 of the 17 warmest years in history have taken place since $2001^{19}$. As climate change is high on the global agenda, almost every nation has signed the 2015 Paris Agreement. The main objective of the agreement is to limit global temperature increases to below $2^{\circ} \mathrm{C}$ above pre-industrial levels. However, as the effects of global warming are already severely felt, there is a need to increase resilience to climate

${ }^{16}$ Przyszłość jakiej chcemy, final document of the United Nations Conference of 20-22 June 2012.

${ }^{17}$ Reflection Paper Towards a Sustainable Europe by 2030 COM(2019) 22.

${ }_{18}$ Sustainable development in the European Union-Monitoring report on progress towards the SDGs in an EU context, https://ec.europa.eu/eurostat/documents/3217494/9237449/KS-01-18-656-EN-N.pdf/2b2a096b3bd6-4939-8ef3-11cfc14b9329 [access: 23.04.2019].

${ }^{19}$ Long-Term Warming Trend Continued in 2017: NASA, NOAA, https://www.nasa.gov/press-release/ long-term-warming-trend-continued-in-2017-nasa-noaa [access: 12.05.2019]. 
change. In order to achieve both mitigation and adaptation goals, it may be helpful to look at the potential of buildings in a different way.

Buildings require huge amounts of energy, which contributes to greenhouse gas emissions. Green building projects aim to reduce the environmental impact of buildings throughout their life cycle (from planning, design, construction, use and disposal) by targeting water saving and energy efficiency initiatives, including smart meters and LED lighting.

As more funding is made available through the initiatives agreed under the Paris Agreement, we can expect further development of green infrastructure as climate change mitigation efforts intensify. In addition to mitigation measures, there is also a growing need to address the consequences of climate change. Given the risk of extreme weather conditions and the realities of long-term changes and variability in weather patterns caused by global warming, adaptation projects aim to strengthen the resilience of buildings, critical infrastructure (such as transport) and, above all, the health of communities.

Ultimately, the benefits of green infrastructure projects are twofold: they can mitigate the production of greenhouse gas emissions and provide additional resilience to global warming. In this way, they can bring together communities and economies to find common strategies to combat climate change.

\section{Bibliography}

Cameron D., The Low Carbon Economy Security, Stability And Green Growth, The Conservative Party, "Protecting Security Policy Green Paper" 2010, No 8.

$\operatorname{COM}(2012) 497$ Enhancing and focusing EU international cooperation in research and innovation: A strategic approach, https://ec.europa.eu/research/iscp/pdf/policy/com 2012497 communication from commission to inst en.pdf [access: 12.06.2019].

COM(2012) 710 Proposal for a Decision of the European Parliament and of the Council on a General Union Environment Action Programme to 2020 ,Living well, within the limits of our planet", https://ec.europa.eu/transparency/regdoc/rep/1/2012/EN/1-2012-710-EN-F1-1. Pdf [access: 2.06.2019].

$\operatorname{COM}(2018) 773$ A Clean Planet for all. A European long-term strategic vision for a prosperous, modern, competitive and climate neutral economy, https:/eur-lex.europa.eu/legal-content/EN/ TXT/HTML/?uri=CELEX:52018DC0773\&from=pl [access: 2.06.2019].

COM(2019) 22 Reflection Paper Towards a Sustainable Europe by 2030, https://eur-lex.europa. eu/legal-content/EN/TXT/HTML/?uri=CELEX:52019DC0022\&from=EN [access: 2.06.2019].

Eco-innovation Action Plan, https://ec.europa.eu/environment/ecoap/frontpage en [access: 23.04.2019].

Effort sharing: Member States'emission targets, https://ec.europa.eu/clima/policies/effort_en [access: 21.04.2019].

Guide to resource efficiency in manufacturing: Experiences from improving resource efficiency in manufacturing companies, Europe INNOVA, 2012.

Hovi J., Sprinz D.F., Underdal A., Implementing Long-Term Climate Policy: Time Inconsistency, Domestic Politics, International Anarchy, "Global Environmental Politics", Volume 9, Number 3, August 2009. 
Long-Term Warming Trend Continued in 2017: NASA, NOAA, https://www.nasa.gov/pressrelease/long-term-warming-trend-continued-in-2017-nasa-noaa [access: 12.05.2019].

Przyszłość, jakiej chcemy, final document of the United Nations Conference of 20-22 June 2012, http://www.unic.un.org.pl/rio20/folder1.pdf [access: 2.06.2019].

Sachs J., Nasze wspólne bogactwo. Ekonomia dla przeludnionej planety, Warszawa 2009.

Sustainable development in the European Union-Monitoring report on progress towards the SDGs in an EU context, https://ec.europa.eu/eurostat/documents/3217494/9237449/KS-0118-656-EN-N.pdf/2b2a096b-3bd6-4939-8ef3-11cfc14b9329 [access: 23.04.2019].

The New Urban Agenda, http://habitat3.org/wp-content/uploads/NUA-English.pdf [access: 21.04.2019].

Towards the Circular Economy: Economic and business rationale for an accelerated transition, Ellen MacArthur Foundation, 2012.

Zdrowe budynki, zdrowsi ludzie, https://www.env-health.org/wp-content/uploads/2018/05/ Healthy-Buildings-_pl-V1-1.pdf [access: 12.05.2019].

Zielone budownictwo a rola samorzadu, https://www.przestrzen-miejska.pl/artykul/zielonebudownictwo-a-rola-samorzadu [access: 12.05.2019]. 


\section{P. Mikuli (red.), Instytucje ombudsmana w państwach anglosaskich: studium porównawcze, Wydawnictwo Sejmowe, Warszawa 2017, ISBN 978-83-7666-502-3, s. 317}

Instytucja ombudsmana, wywodząca się pierwotnie ze Szwecji, rozprzestrzeniła się na szeroką skalę po II wojnie światowej w wielu krajach na różnych kontynentach. Obecnie urząd ten istnieje w przeszło 110 państwach na całym świecie. Instytucja ta, w wielu krajach mająca swoje nazewnicze odpowiedniki oraz posiadająca szczegółowe tryby funkcjonowania, przede wszystkim jest samodzielnym, niezależnym urzędem zajmującym się kontrolą działalności władzy wykonawczej, w szczególności zaś administracji publicznej. Ombudsman zarówno rozpatruje skargi osób fizycznych, przedsiębiorstw czy organizacji, jak i podejmuje działania z własnej inicjatywy, nie pobierając dodatkowych opłat za swoje działania. Co jest szczególnie bliskie naszemu krajowi, w ramach Unii Europejskiej (UE) również został ustanowiony Europejski Rzecznik Praw Obywatelskich, który bada wszelkie pojawiające się skargi dotyczące działalności instytucji, urzędów, organów czy agencji UE. Wciąż wzrastające znaczenie instytucji ombudsmana pociąga za sobą konieczność podjęcia tematyki dotyczącej szeroko zakrojonego rozwoju tej instytucji w państwach nie tylko Europy czy Unii Europejskiej, ale również innych kontynentów. Zadania tego podjęli się autorzy monografii Instytucje ombudsmana w państwach anglosaskich: studium porównawcze, która ukazała się w 2017 roku pod redakcją Piotra Mikulego.

Recenzowana monografia naukowa stanowi zbiór kluczowych wyników projektu badawczego finansowanego ze środków Narodowego Centrum Nauki, o czym informuje 
w uwagach wprowadzających P. Mikuli, pod którego kierownictwem ten kilkuletni projekt był realizowany. Praca składa się z części wprowadzającej oraz siedmiu rozdziałów. Dodatkowo wyszczególnione zostały cztery załączniki przedstawione w postaci szablonów rozwiązań instytucjonalnych i kompetencji instytucji ombudsmana w państwach skandynawskich oraz omawianych państwach anglosaskich. Zawiera ona analizę pozycji ustrojowej i kompetencji instytucji ombudsmana w Zjednoczonym Królestwie oraz w trzech wybranych państwach Wspólnoty Narodów, to jest Australii, Kanadzie i Nowej Zelandii. Podjęte rozważania koncentrują się na odpowiedzi na pytanie, czy istnieje zestaw szczególnych cech wyróżniających instytucję ombudsmana w omawianych państwach, zarówno w zestawieniu z klasycznym modelem nordyckim, jak i z rozwiązaniami w państwach nienależących do anglosaskiego kręgu kulturowego.

Część wprowadzająca ma szczególne znaczenie dla całościowego obrazu i interpretacji zawartych w prezentowanej pozycji konkluzji. Autor wprowadzenia zwraca uwagę na istotność tematyki oraz celów stanowiących podstawę prowadzonych badań. Słusznie podjęto się przeprowadzenia analizy znaczenia instytucji ombudsmana oraz roli, jaką pełni ona obecnie we współczesnych państwach. Co istotne, zwrócono również uwagę na - wydawałoby się mające mniejsze znaczenie, lecz bardzo ważne dla niezaznajomionego z tematem czytelnika - kwestie dotyczące wyjaśnienia pojęć czy wyboru państw poddawanych analizie i jego uzasadnienia. Ważnym elementem jest również przedstawienie przedmiotu badań, ujętego powyżej głównego pytania badawczego, kluczowych założeń wstępnych oraz ramowego planu działań badawczych i jego przebiegu. Zawarte w monografii tego typu aspekty sprawnie wprowadzają w kontekst poruszanych zagadnień i pozwalają na zajęcie własnego stanowiska z uwzględnieniem zaprezentowanej przez realizatorów projektu perspektywy badawczej.

Rozdział pierwszy, Ewolucja modelu ombudsmana w ujęciu teoretycznym (Agnieszka Gajda), podejmuje kwestie związane ze znaczeniem instytucji ombudsmana, etapami jej kształtowania w państwach demokratycznych oraz zmieniającą się rolą, formowaną na przestrzeni lat. $Z$ wielowątkowego zakresu ewolucji modelu ombudsmana wyodrębniono, skupiając na nich zasadniczą uwagę, zagadnienia dotyczące rozwoju instytucji ombudsmana w kontekście rosnącej roli przestrzegania praw człowieka, gdzie sukcesywnie łączono działalność wykonywaną przez ombudsmana w znaczeniu klasycznym z koniecznością ochrony i promocji praw człowieka oraz podstawowych wolności. W uporządkowany sposób zaprezentowano modele ombudsmana, wyróżnione w zależności od stopnia zaangażowania w ochronę praw człowieka. To ujęcie w pewien sposób rzutuje na postrzeganie tej instytucji oraz interpretację dalszych rozdziałów recenzowanej pozycji.

Druga część Źródło inspiracji instytucji ombudsmana - rozwiązania skandynawskie (Bartłomiej Kucia, Piotr Mikuli) to w pierwszej kolejności analiza narodzin i ewolucji instytucji ombudsmana w państwach nordyckich: Szwecji, Finlandii, Danii, Norwegii i Islandii. Wskazanie kluczowych elementów kształtujących ten urząd w poszczególnych państwach pozwala na zobrazowanie głównych różnic i podobieństw w jego rozwoju, a także prześledzenie etapów ewolucji z uwzględnieniem najważniejszych wydarzeń historycznych mających miejsce w wybranych krajach. Główna charakterystyka skupia się na przedstawieniu pozycji ustrojowej ombudsmanów oraz sposobu powoływania 
i organizacji tego urzędu, jak i jego głównych kompetencji wobec sądów i administracji. Autorzy słusznie wskazują na pewne, wyłonione w toku prowadzonych analiz, cechy charakterystyczne instytucji ombudsmana w krajach nordyckich, które po zestawieniu stanowią elementy składające się na model określony jako skandynawski (nordycki) lub klasyczny. Badacze nie zapominają jednak o różnicach w funkcjonowaniu instytucji ombudsmana w omawianych państwach i wskazują na dwie odmienne grupy, gdzie w pierwszej umieszczają najstarsze urzędy ombudsmanów funkcjonujące w Szwecji i Finlandii, a w drugiej pozostałe państwa regionu. Inne kryteria rozróżniające to na przykład zakres kontroli przysługujący ombudsmanom czy kwestia uprawnień prokuratorskich.

Trzeci rozdział monografii, Pierwszy ombudsman anglosaski: casus Nowej Zelandii (Mirosław Wróblewski), traktuje o powstaniu i prężnym kształtowaniu instytucji ombudsmana w Nowej Zelandii, będącej pierwszą tego typu instytucją w krajach anglosaskich. Badacz koncentruje się przede wszystkim na przedstawieniu tego urzędu od początku jego powstania, zwracając szczególną uwagę na miejsce ombudsmana w systemie ustrojowym państwa, jego kluczowe funkcje i pełnione zadania oraz etapy postępowań ombudsmańskich. W końcowej części rozdziału została zawarta ocena działalności ombudsmana w Nowej Zelandii oraz wnioski dotyczące przyszłego kształtowania tej instytucji, gdzie podkreślono jej dynamiczny rozwój oraz prewencyjny i monitorujący charakter funkcjonowania. To właśnie utworzony w Nowej Zelandii urząd ombudsmana wywarł niezaprzeczalny wpływ na powstawanie tego typu urzędów w innych krajach anglosaskich i stał się ważnym odnośnikiem dla rozwoju tej instytucji.

Kolejna część publikacji, Ombudsmani w systemie ustrojowym Zjednoczonego Królestwa (Aleksander Dańda, Piotr Mikuli), ma za zadanie wprowadzić czytelnika w tematykę dotyczącą powstawania instytucji ombudsmana w Zjednoczonym Królestwie Wielkiej Brytanii i Irlandii Północnej. Duże znaczenie dla funkcjonowania tego urzędu na badanym obszarze ma uwidoczniona ewolucja systemu ombudsmańskiego w kierunku pluralistycznym, gdzie $\mathrm{z}$ biegiem lat coraz bardziej charakterystyczne stawało się tworzenie odrębnych instytucji dla Irlandii Północnej, Szkocji i Walii, a także z uwzględnieniem płaszczyzny kompetencyjnej. Szczegółowemu omówieniu poddane zostały urzędy: Ombudsman Parlamentarny oraz ds. Służby Zdrowia, Ombudsman ds. Służb Publicznych dla Walii, Szkocki Ombudsman ds. Służb Publicznych oraz Ombudsman ds. Służb Publicznych dla Irlandii Północnej. Autorzy w uwagach końcowych zawarli główne postulaty dotyczące przyszłościowych reform odnośnie do funkcjonowania instytucji ombudsmańskich, co pozwala czytelnikowi spojrzeć z krytycznego punktu widzenia na dalszą ewolucję tego urzędu w Zjednoczonym Królestwie.

Rozdział piąty, Ombudsmani w systemie ustrojowym Kanady (Aleksander Dańda), pozwala zapoznać się z systemem instytucji typu ombudsmańskiego w Kanadzie, który przede wszystkim cechuje się decentralizacją na szczeblu części składowych federacji oraz bardzo rozbudowaną specjalizacją na szczeblu federalnym. Badacz podjął wysiłek przeanalizowania dwóch wybranych instytucji funkcjonujących na szczeblu prowincji: Ombudsman Ontario i Ombudsman Alberty oraz dwóch wybranych instytucji funkcjonujących na szczeblu federalnym: Ombudsman ds. Zamówień Publicznych i Urząd Kontrolera Instytucji Penitencjarnych. Wyciągnięte wnioski wskazują na daleko posuniętą 
decentralizację mechanizmu ochrony ombudsmańskiej w Kanadzie, która związana jest przede wszystkim z podziałem odpowiedzialności za tę ochronę w dużej mierze pomiędzy poszczególne prowincje i terytoria. Wskazane zostały również główne kwestie dyskusyjne dotyczące braku chęci do utworzenia jednego centralnego organu typu ombudsmańskiego w analizowanym państwie.

Treści ujęte w rozdziale Ombudsmani w systemie ustrojowym Australii (Mirosław Wróblewski) dotyczą systemu ochrony ombudsmańskiej Australii utworzonego w ślad za kształtem systemu ustrojowego tego państwa. Przeważająca część opracowania ma za zadanie wprowadzić czytelnika w tematykę funkcjonowania instytucji ombudsmana na szczeblu federalnym obejmującą status i organizację urzędu, jurysdykcję oraz funkcje i zadania ombudsmana federalnego. Dodatkowo podjęto rozważania odnoszące się do ewolucji i powstawania instytucji ombudsmanów stanowych i terytorialnych w omawianym kraju. Warte podkreślenia i uwagi są zawarte w ostatniej części wnioski odnośnie do pracy ombudsmanów w Australii i ich znacznego obciążenia, a także zmieniającej się ich roli, to jest przechodzenia od wyłącznie przyjmowania i rozpatrywania skarg indywidualnych do pełnienia systemowej funkcji podejmowania działań na rzecz poprawy systemu administracyjnego w całym państwie.

Rozdział siódmy, zatytułowany $W$ poszukiwaniu anglosaskiego modelu instytucji ombudsmana (Bartłomiej Kucia, Piotr Mikuli, Michał Podsiadło), stanowi zwięzłe podsumowanie treści będących przedmiotem rozważań zawartych w poprzednich częściach. Kluczową kwestią poruszoną w tym rozdziale jest wzajemne porównanie rozwiązań ustrojowych zastosowanych w przedstawionych wcześniej państwach oraz w zestawieniu z innymi wybranymi państwami. W sposób spójny, syntetyczny i przystępny dla każdego czytelnika, w podziale na wyszczególnione zagadnienia, przedstawiono najistotniejsze wnioski płynące z przeprowadzonych badań. W konkluzjach podkreślono, że analiza unormowań występujących w państwach anglosaskich nie wskazuje na istnienie wypracowanego jednego, spójnego modelu instytucji typu ombudsmańskiego wspólnego dla tego obszaru. Niemniej, można wskazać kilka kluczowych cech charakterystycznych rozwiązań dotyczących funkcjonowania instytucji ombudsmana występujących w systemach prawnych państw wybranych do analizy.

Należy uznać, że postawiony na wstępie cel badawczy został osiągnięty. Autorzy odpowiedzieli na postawione na początku pytanie, mianowicie czy istnieje zestaw szczególnych cech wyróżniających instytucję ombudsmana w omawianych państwach, zarówno w zestawieniu z klasycznym modelem nordyckim, jak i z rozwiązaniami w państwach nienależących do anglosaskiego kręgu kulturowego. Główne rozważania dotyczące kluczowych cech charakterystycznych zostały przedstawione w poszczególnych rozdziałach dotyczących analizowanych państw, gdzie każdy z autorów starał się zwracać fundamentalną uwagę na podobieństwa i różnice występujące $\mathrm{w}$ zestawieniu $\mathrm{z}$ pozostałymi państwami podlegającymi analizie oraz innymi wybranymi państwami. Następnie uwagi te zostały zestawione i podsumowane w rozdziale ostatnim, wraz z dodatkowymi komentarzami weryfikującymi. Autorzy wykazują się dobrą znajomością omawianej tematyki i orientacją w owej dziedzinie, trafnie uzasadniając i identyfikując poruszane zagadnienia. Zaplanowane i wykonane działania badawcze, jak i ich przebieg wydają 
się słuszne z punktu widzenia realizacji celu. Również trafność argumentacji oraz logika formułowanych wypowiedzi nie budzą zastrzeżeń w kontekście prowadzonej analizy porównawczej.

Odnośnie do struktury i treści recenzowanej monografii naukowej opracowanie zostało napisane w sposób czytelny i zrozumiały dla każdego odbiorcy, zarówno specjalizującego się i zaznajomionego z zagadnieniami w większym lub mniejszym stopniu, jak i dla osoby, która nigdy wcześniej nie miała styczności z poruszanym obszarem. Dodatkowo należy wskazać na poprawny język i stylistykę oraz płynność przekazu, co powoduje, że prezentowane zagadnienia czyta się z łatwością. Podział pracy jest logiczny i przejrzysty, dzięki czemu dla każdego możliwe jest zrozumienie złożoności i wielowymiarowości treści. Obszerność poszczególnych rozdziałów jest do siebie zbliżona oraz dostosowana objętościowo do poruszanych wątków. W niektórych rozdziałach pewne zagadnienia zazębiają się, co niekiedy powoduje nakładanie się w nich zawartych tych samych informacji, jednak z drugiej strony pozwala na zapoznanie się z problematyką w dowolnej kolejności, gdzie czytelnik sam decyduje, które rozdziały szczególnie go interesują. Dodatkowo należy podkreślić, co zwraca uwagę już na samym początku, że choć rozdział pierwszy wprowadza czytelnika w ogólną tematykę dotyczącą kształtowania instytucji ombudsmana, to jednak można by zaryzykować stwierdzenie, że istnienie bądź nie tego fragmentu nie ma wpływu na całościową treść monografii, jak i realizację postawionego celu. Wartością dodaną, istotną z punktu widzenia czytelności i dostępności, są sporządzone i znajdujące się na końcu publikacji trzy wykazy: skrótów, aktów normatywnych cytowanych w pracy oraz orzeczeń sądowych cytowanych w pracy. Wykaz aktów normatywnych został przedstawiony w podziale na poszczególne państwa, dzięki czemu z łatwością można zapoznać się z dodatkowymi, wzbudzającymi zainteresowanie treściami. W monografii wykorzystano bogaty zasób pozycji bibliograficznych, wśród których znajduje się literatura zarówno polskojęzyczna, jak i obcojęzyczna, co umożliwia czytelnikowi pogłębienie swojej wiedzy oraz łatwiejsze zrozumienie omawianych zagadnień. W bibliografii znajdują się między innymi monografie, artykuły w pracach zbiorowych, artykuły w czasopismach, pozycje związane z badaniami własnymi - kwestionariusze badawcze czy wywiady.

Recenzowana publikacja z całą pewnością posiada walor naukowy i dydaktyczny oraz jest odpowiednim materiałem dla wielu odbiorców - naukowców, badaczy, a także studentów różnych kierunków i uczelni w Polsce. Analizowana praca stanowi znaczny wkład w rozwój badań nad kształtowaniem instytucji ombudsmana zarówno w szerszym kontekście, jak i wyłącznie w krajach anglosaskich, dzięki czemu może stać się podstawą $\mathrm{i}$ inspiracją do prowadzenia dalszych badań w tym jakże zmiennym i szybko rozwijającym się obszarze. 


\section{Joanna Sośnicka (ed.), Engineer with a Humanist's Soul. Humanistic Issues of Technological World, Wydawnictwo Politechniki Lódzkiej, Lódź 2019, s. 326}

Monografia pod redakcją Joanny Sośnickiej, zatytułowana Engineer with a Humanist's Soul. Humanistic Issues of Technological World jest kontynuacją, drugim tomem (choć bez tej etykiety), rozwinięciem i uzupełnieniem książki tej samej redaktorki pt. Inżynier $z$ dusza humanisty. Miejsce $i$ rola problematyki humanistycznej $w$ dyskursie politechnicznym, wydanej przez Wydawnictwo Politechniki Łódzkiej w roku 2017. Tym razem jednak zebrane w tomie rozdziały stanowią zbiór tekstów anglojęzycznych. Prezentują one jednak perspektywę wielokulturową i wielonarodową. Autorzy zawartych w książce rozdziałów reprezentują uniwersytety czternastu krajów. Są wśród nich: Liechtenstein, Senegal, Wielka Brytania, Portugalia, Australia, Izrael, Holandia, Uganda, Francja, Grecja, Włochy, Chile, Stany Zjednoczone, Niemcy.

Podejmowane przez autorów monografii zagadnienia związane są z potrzebą wzbogacenia kształcenia inżynieryjnego o wiedzę rozwijającą kompetencje społeczne, współpracę i komunikację, wpływającą na niezbędną i tak współcześnie oczekiwaną innowacyjność. Polskie uczelnie różnie sobie $\mathrm{z}$ tym radzą, czego dowodem były zawarte w tomie pierwszym artykuły zmagających się z opisywaną materią naukowców i wykładowców akademickich.

Tymczasem na przykład uczelnie amerykańskie włączają do oferty kształcenia przedmioty mające pomóc $\mathrm{w}$ uświadomieniu studentom wagi równości, promowanie intersekcjonalności, kursy obejmujące wiedzę o organizacji społeczeństwa, wartościach kulturowych oraz tworzą sieci łączące pracowników i studentów czy wzmacniające kampusową społeczność. Celem takich zajęć i aktywności jest wspomaganie badań naukowych i inżynierskich 
w zapewnieniu wysokiej jakości wyników pracy, wspomaganie społeczeństwa - przez kierowanie badaniami, tak by odpowiadały społecznym potrzebom, oraz wspomaganie biznesu, rozwijanie nowych idei, patentów, technologii. Są to niezwykle aktualne i ważne zagadnienia, wciąż jednak niedoceniane w Polsce na tyle, na ile zasługują.

Dlatego tym razem do współpracy nad projektem związanym z miejscem nauk humanistycznych i społecznych w badaniach z zakresu nauk technicznych oraz procesie kształcenia politechnicznego Joanna Sośnicka zaprosiła badaczy i wykładowców ze świata, by podzielili się doświadczeniem i dobrymi praktykami, które być może będą miały wpływ także na polską recepcję opisywanych zagadnień.

Praca liczy 324 strony i składa się z wstępu i trzech rozdziałów. We wstępie pomysłodawczyni tomów przedstawia główną ideę przygotowania publikacji i odwołuje się do będącego inspiracją eseju prof. Marii Stolarskiej Technik z dusza humanisty, która podejmowała podobne zagadnienia przed dwudziestu laty. Wprowadzenie to poprzedzone jest, tak jak w tomie pierwszym, wspomnianym artykułem przedrukowanym z „Forum Akademickiego" 11(1999), tym razem w języku angielskim.

Rozdział pierwszy zatytułowany Technika a humanistyka i obecnie Humanities and Technology zawiera sześć artykułów. Są to teksty: The Humanist Engineer Marka Webba, Richarda Burgessa i Indiry Kuntuovej; When the Humanities enter the engineering lab Cheikha Mbacke Gueye'a; Ignoring the humanities: some reasons to understand Abdoulaye'a Ba; What is the 'value-added' of being human? Steve'a Fullera; Closing the fractures of our souls. Philosophy and the meaningful life Carlosa Sousy'ego Reisa i Marii Formosinho oraz The soft side of technology. The Triple I approach Maartena J. Verkerka.

Rozdział drugi pt. Humanistyczne aspekty inżynierii - Humanistic Aspects of Engineering zawiera teksty: Touching the virtual: the body and VR technologies Anne Cranny-Francis; The innovative engineer: Qualitative reasoning in response to uncertainty Yakovaa Ben-Haima; Contextualizing the engineer's participation in socio-technical networks of the design Florence Lubwamy Kiyimby; Contextualizing the engineer's participation in socio-technical networks of the design Harro Maata; Working together to solve the problems of society Hilary Yerbury; The need of an integrated design for smart grids. The development of renewable sources: wind mills, photovoltaic plants and solar panels for households Maartena J. Verkerka oraz Engineers and capitalism. Lessons from the early twentieth century autorstwa Paula F. Ribeiro i Oliviera Brette'a.

Rozdział trzeci zaś nosił tytuł Humanistyka w edukacji i nauce - Humanities in Engineering Education i składa się z siedmiu części prezentujących prace: The true grand challenge for engineers: self-knowledge Carla Mitchama; Technocracy and the necessity of humanistic values in engineering education Joannisa Markopoulosa; The humanistic education for the future engineer Teresy Marii Russo i Valery'ego Luki; Bachelor of arts in engineering Louisa Bucciarelliego; The place and role of humanistic issues in future engineering and engineering education. A perspective from gender studies at a technical University in Germany Susanne Ihsen; Engineers and the multiplicity of knowledge Tanji Kubes i Goverta Valkenburga oraz Humanities and social sciences at faculty of mechanical engineering and Naval Architecture at Zagreb Dubreta Nikša. 
Entuzjastycznie więc polecam recenzowaną książkę. Wszyscy, a szczególnie zainteresowani problematyką technohumanistyki znajdą w niej informacje o najnowszych badaniach zarówno z zakresu nauk humanistycznych, jak i społecznych, gdyż każdy z tekstów wieńczy bogata bibliografia. Praca Joanny Sośnickiej stanowi niezwykle cenną pozycję zwłaszcza dla polskich odbiorców, którzy mogą dzięki niej wzbogacić swój warsztat, jak również podejście badawcze, a ponadto znaleźć w niej wiele inspiracji. 
ARTYKUŁY - DYSKUSJE - ESEJE

Anna Sikora Pusty tron władzy, czyli o dylematach władzy ludu w demokracjach

Anna Fligel Shmuel N. Eisenstadt w nowej odsłonie. Wokół książki Varieties of Multiple Modernities. New Research Design

Waldemar Mańkowski Polityka gospodarcza jako działanie państwa na tle globalnych zmian

Robert Krzemień Patriotyzm ekonomiczny - droga do wzmocnienia gospodarki, czy droga donikąd?

Weronika Wojtanowska O możliwości zastosowania Nagelowskiej typologii racji do działania we współczesnej etyce cnót MISCELLANEA

Angelika Gieraś Problem demokracji w Unii Europejskiej PRACE STUDENTÓW

Galyna Biletska Analisys of support levels of fair-right political parties in Sweden and France caused by political/economic trigger of migration

Faina Nakanechnaya Meaning of borders in post-soviet countries (on the example of Belarus and its neighboring countries)

Sonia Rojeska Gender imbalance in Polish political landscape supported by mainstream media discourse in Poland

Magdalena Wojtas Aspects of European Union climate policy in the context of the opportunities offered by the building sector - innovation in action RECENZJE

Marta Miedzińska Instytucje ombudsmana w państwach anglosaskich: studium porównawcze, pod red. P. Mikulego

Edyta Pietrzak Joanna Sośnicka ed. Engineer with a Humanist's Soul. Humanistic Issues of Technological World 